LATVIJAS LAUKSAIMNIECĪBAS UNIVERSITĀTE

MEŽA FAKULTĀTE

KOKAPSTRĀDES KATEDRA

LATVIJAS VALSTS KOKSNES K̦ĪMIJAS INSTITŪTS

\title{
DACE CĪRULE
}

Promocijas darbs

\section{TERMISKI MODIFICĒTAS LAPKOKU KOKSNES DEKORATĪVĀS İPAŠĪBAS UN TO STABILITĀTES UZLABOŠANA PRET VIDES FAKTORU IEDARBĪBU}

Inženierzinātņu doktora ( $D r$. sc. ing.) zinātniskā grāda iegūšanai Materiālzinātnes nozarē Koksnes materiālu un tehnologiju apakšnozarē

Promocijas darba zinātniskie vadītāji

Dr. habil. sc. ing.

Dr. h. silv. Henn Tuherm

Dr. chem. Bruno Andersons

Promocijas darba autore

Dace Cīrule

Jelgava

2016 


\begin{abstract}
ANOTĀCIJA
Promocijas darbā pētītas termiski modificētas apses un baltalkšņa koksnes dekoratīvās īpašības un to saglabāšanas iespējas ekspluatācijas laikā. Apses un baltalkšņa koksne kā pētījuma objekts izvēlētas, pamatojoties uz pētījuma par Latvijas koksnes resursiem atzinumu, ka Latvijas mīksto lapkoku resursi netiek pietiekoši izmantoti un ir uzkrājušās lielas to rezerves, kam nepieciešams atrast plašākas izmantošanas iespējas, vēlams, radot jaunus produktus ar augstu pievienoto vērtību. Darbā apkopota zinātniskajā literatūrā pieejamā informācija par koksnes termiskās modifikācijas procesiem, modifikācijas izraisītām koksnes morfologiskās un ķīmiskās struktūras, fizikālo un mehānisko īpašību izmaiṇām, koksnes novecošanās norisēm un tās ietekmējošiem faktoriem un pētīšanas metodēm, koksnes aizsardzībai paredzētu pārklājumu pamatkompozīcijām un dažādu funkcionālu piedevu lietošanu pārklājumu efektivitātes nodrošināšanai. Darba ietvaros analizēts koksnes krāsas un ar to saistīto spektrālo izmaiņu raksturs termiskās modifikācijas procesā. Izmantojot gan dabīgās, gan mākslīgās novecināšanas testus, pētītas termiski modificētas koksnes izmaiṇu īpatnības dažādu vides faktoru iedarbības rezultātā, un tās salīdzinātas ar nemodificētai koksnei raksturīgām izmaiņām. Noskaidrots, ka termiski modificēta koksne saglabā savu dekorativitāti tikai apstākḷıs, kad nav pakḷauta tieša saules starojuma iedarb̄̄bai. Analizējot koksnes novecošanās pētījumu rezultātus, secināts, ka nemodificētas un termiski modificētas koksnes spektrālās jutības būtiski atšķiras, un termiski modificētai koksnei ievērojami lielākas gan krāsas, gan k̦īmiskās pārvērtības izraisa saules starojuma redzamās gaismas spektra apgabals. Šīs zināšanas ḷauj mērḳtiecīgāk veidot efektīvus, ekonomiski pamatotus pārklājumu sastāvus, kas paredzēti termiski modificētas koksnes dekorativitātes aizsardzības nodrošināšanai. Darba ietvaros optimizētas termiski modificētai koksnei piemērotu alkīda sveķu pārklājuma saistvielu un funkcionālo piedevu kompozīcijas. Jaunās pārklājumu sistēmas pārbaudītas āra testa apstākḷos un salīdzinātas ar atbilstošiem līdzīgiem rūpnieciskiem pārklājumiem.
\end{abstract}




\begin{abstract}
ANNOTATION
The subject of the Doctoral thesis is decorative qualities of thermally modified aspen and grey alder wood and the ways how to maintain them during outdoor exposure. Aspen and grey alder woods have been chosen for the study on the basis of the investigation about Latvian wood resources which has revealed that a great quantity of low density hardwood resources have accumulated in forests without proper utilization and, therefore, new ways of application of these wood resources have to be looked for with the aim to design products with high added value. There is given a review of the relevant literature on the processes of wood thermal modification, the changes in wood structural, chemical, physical and mechanical properties caused by the thermal treatment, the wood weathering processes and the factors influencing them as well as the methods used for the investigation of these processes. The basic coating systems used for wood protection and the use of different additives to enhance efficiency of coatings are reviewed. The effect of thermal treatment on wood colour and the characteristic trends of spectral changes due to this process are analysed. The peculiarities of changes in thermally modified wood caused by different environmental factors are examined during both natural and artificial weathering tests. The results are compared with those of unmodified wood. The tests showed that the thermally modified wood surface is stable only in an environment where it is protected from solar radiation. The analyses of the wood weathering results revealed that there are substantial differences in the spectral sensitivity of unmodified and thermally modified wood. The visible light of the solar radiation causes considerably greater discolouration and changes in chemical structure for thermally modified wood in comparison with unmodified wood. This knowledge could help to design more efficient and cost-effective coating systems intended for maintenance of aesthetic properties of thermally modified wood used outdoors. The solvent-based alkyd coatings binder system and functional additives composition have been optimized to enhance thermally modified wood performance outdoors. The upgraded coating formulation performance has been examined during outdoor weathering and compared with commercial coatings of the same type.
\end{abstract}




\section{SATURA RĀDĪTĀJS}

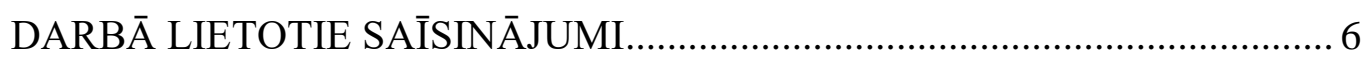

DARBĀ IEKL̨AUTO TABULU SARAKSTS................................................... 7

DARBĀ IEKL̨,AUTO ATTĒLU SARAKSTS ............................................... 8

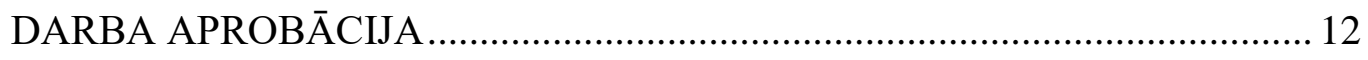

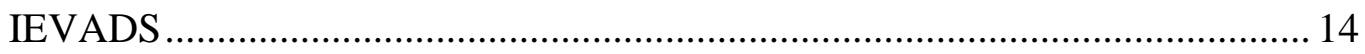

1. SITUĀCIJAS ANALĪZE (LITERATŪRAS APSKATS) ................................ 17

1.1. Koksnes termiskā modifikācija ................................................................ 17

1.1.1. Termiskās modifikācijas procesi ....................................... 17

1.1.2. Koksnes izmaiņas termiskās modifikācijas procesā ......... 19

1.2. Koksnes novecošanās procesi ................................................................ 29

1.2.1. Koksni ietekmējošie vides faktori...................................... 30

1.2.2. Koksnes izmaiņas vides faktoru iedarbības rezultātā ....... 33

1.2.3. Vides faktoru ietekme uz termiski modificētu koksni ...... 36

1.2.4. Novecināšanas testi........................................................... 37

1.3. Koksnes aizsardzība pret vides faktoru iedarbību.................................... 39

1.3.1. Koksnes pārklājumi un to veidi .......................................... 39

1.3.2. Koksnes pārklājumu modifikācija ar funkcionālām piedevām ..................................................... 45

1.3.3. Pārklājumu ekspluatācijas īpašības atkarīibā no

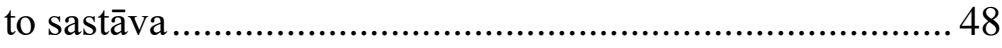

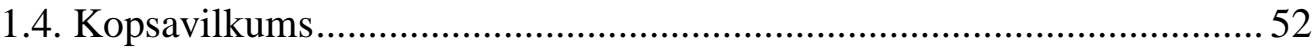

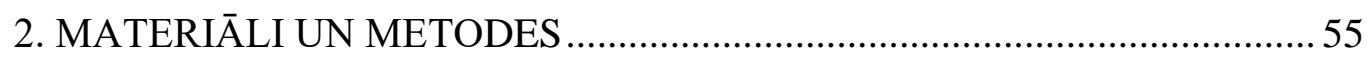

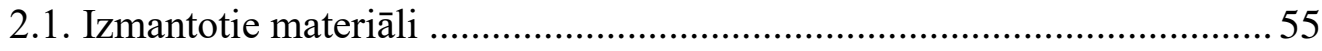

2.2. Koksnes termiskā modifikācija ............................................................ 55

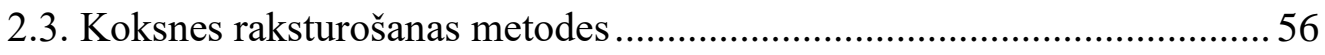

2.3.1. Koksnes krāsas raksturošana …………………………..... 56

2.3.2. Koksnes krāsas homogenitātes noteikšana .......................... 58

2.3.3. Koksnes virsmas ḳīmiskā sastāva noteikšana ..................... 58

2.3.4. Koksnes virsmas mikrostruktūras analīze ar SEM ........... 59

2.4. Koksnes novecināšanas testi .................................................................. 59

2.4.1. Dabīgā novecināšana ………………………………….... 59

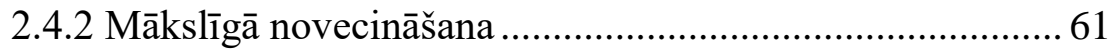

2.5. Pārklājumu pagatavošana, raksturošana, testēšana ................................... 62

2.5.1. Pārklājumu pagatavošana ................................................ 62 


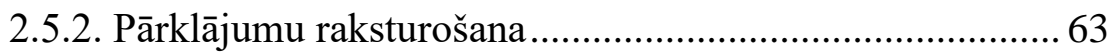

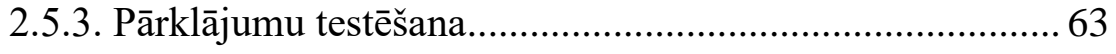

2.6. Pārklātu paraugu novecināšanas testi ................................... 65

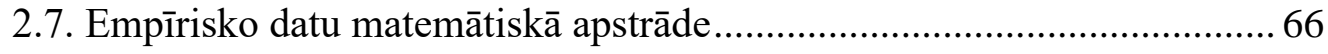

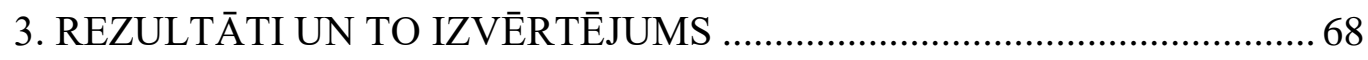

3.1. Termiski modificētas koksnes krāsa .................................................... 68

3.1.1. Koksnes krāsas izmaiņas termiskās modifikācijas procesā.................................................. 68

3.1.2. Termiski modificētas koksnes krāsas homogenitāte......... 73

3.2. Termiski modificētas koksnes stabilitāte pret vides faktoru iedarbību .... 79

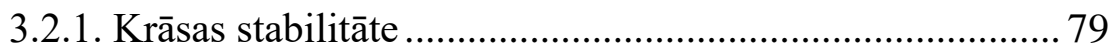

3.2.2. Virsmas ḳīmiskās izmaiṇas............................................. 94

3.2.3. Virsmas mikrostruktūras izmaiņas................................ 100

3.3. Termiski modificētai koksnei piemērota pārklājuma

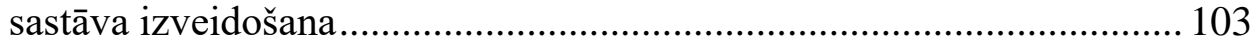

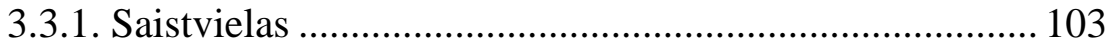

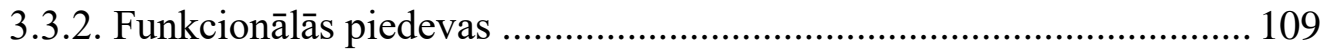

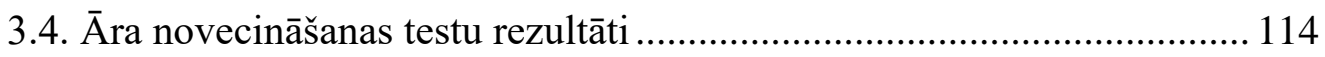

3.4.1. Bezpigmentu pārklājumi.............................................. 114

3.4.2. Dažādas koncentrācijas dzelzs oksīdu pigmenti ............. 116

3.4.3. Dažādas dzelzs oksīdu kompozīcijas ............................. 118

3.4.4. Pigmentēti pārklājumi ar UV absorbera piedevu............. 120

4. SECINĀJUMI UN PRIEKŠLIKUMI........................................................ 122

INFORMĀCIJAS AVOTU SARAKSTS ..................................................... 124 


\section{DARBĀ LIETOTIE SAĪSINĀJUMI}

\begin{tabular}{|c|c|}
\hline$a^{*}$ & CIELAB krāsu modeḷa krāsainības parametrs (sarkanā - zaḷā ass) \\
\hline$b^{*}$ & CIELAB krāsu modeḷa krāsainības parametrs (dzeltenā - zilā ass) \\
\hline $\mathrm{BP}$ & Benzofenoni (UV absorberu klase) \\
\hline BTZ & Benzotriazoli (UV absorberu klase) \\
\hline CIELAB & $\begin{array}{l}\text { Starptautiskās Apgaismošanas komisijas (Commission Internatiomale } \\
\text { de l'Eclairage) ieteiktais krāsu modelis }\end{array}$ \\
\hline$\Delta \mathrm{Eab}$ & Krāsas atšķirības (CIELAB krāsu modelis) \\
\hline DSC & Diferenciālā skenējošā kalorimetrija \\
\hline EPS & Eksperimentālais pārklājuma sastāvs \\
\hline FTIR & Furjē transformāciju infrasarkanā spektroskopija \\
\hline HPT & Hidroksifenil-s-triazīni (UV absorberu klase) \\
\hline IPBC & Jodo-propinil-butil-karbamāts (biocīds) \\
\hline IS & Infrasarkanais starojums \\
\hline $\mathrm{L}^{*}$ & CIELAB krāsu modeḷa gaišuma parametrs \\
\hline PC & Pilns novecināšanas cikls, kas atbilst LVS EN 927-6 \\
\hline $\mathrm{RH}$ & Relatīvais gaisa mitrums \\
\hline SEM & Skenējošais elektronu mikroskops \\
\hline $\mathrm{T}_{\mathrm{g}}$ & Stiklošanās temperatūra \\
\hline $\mathrm{TiO}_{2}$ & Titāna dioksīds \\
\hline UV & Ultravioletais starojums \\
\hline UVA-340 & $\begin{array}{l}\text { Ultravioletā starojuma lampas ar maksimālo starojuma intensitāti pie } \\
343 \mathrm{~nm}\end{array}$ \\
\hline UV-B & Ultravioletais starojums viḷnu apgabalā $280-315 \mathrm{~nm}$ \\
\hline $\mathrm{ZnO}$ & Cinka oksīds \\
\hline WTT & Wood Treatment Technology \\
\hline
\end{tabular}




\section{DARBĀ IEKL,AUTO TABULU SARAKSTS}

\begin{tabular}{|c|c|c|}
\hline Nr. & Tabulas nosaukums & Lpp. \\
\hline 1.1. & Uz zemes nonākošā saules starojuma spektrālais sadalījums & 30 \\
\hline 1.2 . & Svarīgākās koksnes pārklājumos izmantotās saistvielas & 41 \\
\hline 1.3 . & $\begin{array}{l}\text { Alkīda sveķu izlietojums (1000 tonnas tīru sveķu) dažāàdu } \\
\text { veidu pārklājumiem Eiropā }\end{array}$ & 43 \\
\hline 2.1 . & $\begin{array}{l}\text { Apauguma ar koksnes krāsojošām sēnēm novērtēšanas } \\
\text { kritēriji }\end{array}$ & 64 \\
\hline 2.2 . & Plaisu novērtējuma kritēriji & 66 \\
\hline 3.1. & $\begin{array}{l}\text { Apses un baltalkšņa koksnes masas zudumi un krāsas } \\
\text { izmaiņas } \Delta \text { Eab termiskās modifikācijas procesā pie dažādām } \\
\text { temperatūrām }\end{array}$ & 68 \\
\hline 3.2 . & $\begin{array}{l}\text { Termiski modificētu apses un baltalkšņa dēlu summārās } \\
\text { atstarošanas spektru atšķirības starp dēḷu virsējo un } \\
\text { dzilāākajiem slāṇiem, nosacītās vienības }\end{array}$ & 76 \\
\hline 3.3 . & $\begin{array}{l}\text { Dažādiem starojuma veidiem eksponētas koksnes saṇemtās } \\
\text { kopējās UV starojuma ( } 290 \text { - } 390 \mathrm{~nm}) \text { devas } 40 \text { stundu laikā }\end{array}$ & 86 \\
\hline 3.4 . & $\begin{array}{l}\text { Dažādu starojumu izraisīto relatīvo atstarošanas izmaiṇu } \\
\text { spektru laukumi, vienības }\end{array}$ & 91 \\
\hline 3.5 . & $\begin{array}{l}\text { Nemodificētas un termiski modificētas apses un baltalkšņa } \\
\text { koksnes } \mathrm{O} / \mathrm{C} \text { attiecība pirms un pēc mākslīgās PC } \\
\text { novecināšanas }\end{array}$ & 100 \\
\hline 3.6 . & Eksperimentālo pārklājumu saistvielu sastāvs & 107 \\
\hline 3.7. & $\begin{array}{l}\text { Termiski modificētai koksnei paredzēto gruntsslāņa un } \\
\text { virsslāņa pārklājumu bāzes sastāvs un raksturojums }\end{array}$ & 108 \\
\hline 3.8 . & $\begin{array}{l}\text { Stiklošanās temperatūras Tg pārklājumiem ar dažādiem UV } \\
\text { absorberiem }\end{array}$ & 110 \\
\hline 3.9. & $\begin{array}{l}\text { Termiski modificētas koksnes pārklājumā pievienota biocīda } \\
\text { efektivitātes novērtěšanas laboratorijas testa rezultāti }\end{array}$ & 112 \\
\hline 3.10 . & $\begin{array}{l}\text { Krāsojošās sēnes uz āra testa paraugiem, vidējais vērtējums } \\
\text { ballēs }\end{array}$ & 112 \\
\hline 3.11. & Plaisu novērtējums āra testa paraugiem, summārās balles & 115 \\
\hline
\end{tabular}




\section{DARBĀ IEKḶAUTO ATTĒLU SARAKSTS}

\begin{tabular}{|c|c|c|}
\hline Nr. & Attēla nosaukums & Lpp. \\
\hline 1.1. & CIELAB krāsu modela shematisks attēlojums & 27 \\
\hline 2.1 . & WTT firmas daudzfunkcionālā koksnes modifikācijas pilotiekārta & 55 \\
\hline 2.2 . & CIEALB krāsu modelis & 56 \\
\hline 2.3 . & Krāsu atšķirību shematisks attēlojums & 57 \\
\hline 2.4 . & $\begin{array}{l}\text { Pilna saules un saules caur loga stiklu starojumu spektri UV } \\
\text { apgabalā }\end{array}$ & 60 \\
\hline 2.5 . & $\begin{array}{l}\text { Filtru starojuma caurlaidības spektri UV-redzamās gaismas } \\
\text { apgabalā }\end{array}$ & 61 \\
\hline 2.6. & Mākslīgās novecināšanas kamera Q-Lab & 61 \\
\hline 2.7. & Fluorescento UVA-340 lampu starojuma spektrs & 62 \\
\hline 2.8 . & Āra testa paraugu stends & 65 \\
\hline 2.9 . & Datu atspoguḷošana kastī̌su diagrammu veidā & 67 \\
\hline 3.1. & $\begin{array}{l}\text { Apses un baltalkšṇa koksne pirms un pēc modifikācijas dažādās } \\
\text { temperatūrās }\end{array}$ & 68 \\
\hline 3.2 . & $\begin{array}{l}\text { Nemodificētas un dažādās temperatūrās modificētas apses un } \\
\text { baltalkšna koksnes atstarošanas spektri redzamās gaismas viḷ̣nu } \\
\text { apgabalā }\end{array}$ & 69 \\
\hline 3.3. & $\begin{array}{l}\text { Termiski modificēta }\left(170^{\circ} \mathrm{C}\right) \text { apses koksne pirms, pēc ekstrakcijas } \\
\text { ar ūdeni un pēc ekstrakcija ar acetonu }\end{array}$ & 70 \\
\hline 3.4 . & $\begin{array}{l}\text { Neekstraǵêtas un ar ūdeni un acetonu ekstrageètas termiski } \\
\text { modificêtas }\left(170^{\circ} \mathrm{C}\right) \text { apses koksnes atstarošanas spektri }\end{array}$ & 70 \\
\hline 3.5. & $\begin{array}{l}\text { Termiski modificētas }\left(170^{\circ} \mathrm{C}\right) \text { apses koksnes ūdens un acetona } \\
\text { ekstraktu spektri UV-redzamās gaismas apgabalā }\end{array}$ & 71 \\
\hline 3.6. & $\begin{array}{l}\text { Neekstragètas un ekstragétas termiski modificētas }\left(170^{\circ} \mathrm{C}\right) \text { apses } \\
\text { koksnes krāsas izmainas } \Delta \text { Eab pēc } 100 \text { stundu ekspozīcijas saulē }\end{array}$ & 71 \\
\hline 3.7 . & $\begin{array}{l}\text { Apses un baltalkšña koksnes atstarošanas izmainuu spektri redzamās } \\
\text { gaismas diapazonā termiskās modifikācijas rezultātā }\end{array}$ & 72 \\
\hline 3.8. & $\begin{array}{l}\text { Termiski modificētas apses un baltalkšnna koksnes atstarošanas } \\
\text { izmainnu attiecība modifikācijas temperatūru intervāliem }(160- \\
\left.170^{\circ} \mathrm{C}\right) \text { pret }\left(140-160^{\circ} \mathrm{C}\right)\end{array}$ & 73 \\
\hline 3.9 . & $\begin{array}{l}\text { Nemodificētas un pie dažāāām temperatūrām modificētas apses un } \\
\text { baltalkšṇa koksnes krāsu atškiirības } \Delta \text { Eab starp dẹliem }\end{array}$ & 74 \\
\hline 3.10 . & $\begin{array}{l}\text { Nemodificētas un termiski modificētas apses un baltalkšṇa koksnes } \\
\text { krāsas atšḳirības } \Delta \text { Eab vienā dẹla plaknē }\end{array}$ & 74 \\
\hline 3.11. & $\begin{array}{l}\text { Termiski modificētas apses un baltalkšña koksnes vidējās krāsu } \\
\text { atškirīibas } \Delta \text { Eab starp dēlpa virsslāni un dzilākajiem slāṇiem, parādot } \\
\text { katra krāsu parametra īpatsvaru kopējās atškirirībās }\end{array}$ & 75 \\
\hline 3.12 . & $\begin{array}{l}\text { Atstarošanas spektru atšķirīibas starp termiski modificētu apses un } \\
\text { baltalkšņa dēḷu virskārtu un dziḷākajiem slāṇiem }\end{array}$ & 76 \\
\hline 3.13. & $\begin{array}{l}\text { Gaišuma parametra } L^{*} \text { vērtības termiski modificētu apses un } \\
\text { baltalkšña dēlı slān̨iem dažāasos attālumos no virsmas }\end{array}$ & 77 \\
\hline 3.14 . & $\begin{array}{l}\text { Termiski modificētas apses un baltalkšña koksnes krāsas vidējās } \\
\text { atškirības } \Delta \text { Eab starp slāṇiem } 2 \mathrm{~mm}, 4 \mathrm{~mm} \text { un } 6 \mathrm{~mm} \text { dziḷumā no } \\
\text { dēḷa virsmas }\end{array}$ & 78 \\
\hline
\end{tabular}




\begin{tabular}{|c|c|c|}
\hline Nr. & Attēla nosaukums & Lpp. \\
\hline 3.15 & $\begin{array}{l}\text { Termiski modificētas un nemodificētas apses un baltalkšņa koksnes } \\
\text { krāsas izmaiņas } \Delta \text { Eab } 30 \text { mēnešu laikā tumsā un istabas apstākḷos } \\
\text { bez tiešu saules staru iedarbības }\end{array}$ & 79 \\
\hline 3.16. & $\begin{array}{l}\text { Nemodificētas apses un baltalkšña koksnes atstarošanas izmaiṇas } \\
\text { pēc } 30 \text { mēnešiem dažādos apstākḷos }\end{array}$ & 80 \\
\hline 3.17. & $\begin{array}{l}\text { Termiski modificētas apses un baltalkšña koksnes atstarošanas } \\
\text { izmaiņas pēc } 30 \text { mēnešiem dažādos apstākḷıs }\end{array}$ & 80 \\
\hline 3.18. & $\begin{array}{l}\text { Termiski modificētas }\left(170^{\circ} \mathrm{C}\right) \text { apses koksnes atstarošanas spektru } \\
\text { izmaiņas laikā koksnei atrodoties gaismā bez tiešu saules staru } \\
\text { iedarbības }\end{array}$ & 81 \\
\hline 3.19. & $\begin{array}{l}\text { Dažādās temperatūrās modificētas apses koksnes krāsas izmaiņas } \\
\Delta \text { Eab pēc } 30 \text { mēnešiem gaismā un tumsā }\end{array}$ & 82 \\
\hline 3.20 & $\begin{array}{l}\text { Saules starojuma summārā un saules starojuma UV daḷas }(290 \text { - } 390 \\
\mathrm{nm}) \text { intensitātes variēšana testa laikā }\end{array}$ & 82 \\
\hline 3.21. & $\begin{array}{l}\text { Saules starojuma UV daḷas }(290 \text { - } 390 \mathrm{~nm}) \text { īpatsvara variēšana testa } \\
\text { laikā }\end{array}$ & 83 \\
\hline 3.22 . & $\begin{array}{l}\text { Caur loga stiklu izgājušā saules starojuma UV daḷas }(290 \text { - } 390 \text { nm) } \\
\text { intensitāte atkarībā no pilna saules starojuma UV intensitātes }\end{array}$ & 83 \\
\hline 3.23 . & $\begin{array}{l}\text { Caur loga stiklu izgājušā UV starojuma daḷa atkarībā no pilna saules } \\
\text { starojuma UV (290 - } 390 \mathrm{~nm}) \text { daḷas intensitātes }\end{array}$ & 84 \\
\hline 3.24. & Summārā paraugu saṇemtā UV radiācijas deva dažādos gados. & 84 \\
\hline 3.25. & $\begin{array}{l}\text { Nemodificētas un pie dažāāām temperatūrām modificētas apses } \\
\text { koksnes krāsas izmainas } \Delta \text { Eab pēc } 100 \text { sundu eksponēšanas pilnam } \\
\text { saules starojumam }\end{array}$ & 85 \\
\hline 3.26. & $\begin{array}{l}\text { Nemodificētas un pie dažādām temperatūrām modificētas apses } \\
\text { koksnes atstarošanas spektru izmaiņas pēc koksnes } 100 \text { sundu } \\
\text { eksponēšanas pilnam saules starojumam }\end{array}$ & 85 \\
\hline 3.27. & $\begin{array}{l}\text { Termiski modificētas }\left(170^{\circ} \mathrm{C}\right) \text { apses un baltalkšņa koksnes } \\
\text { atstarošanas spektru izmainas pēc } 30 \text { stundu ekspozīcijas saules } \\
\text { starojumam }\end{array}$ & 86 \\
\hline 3.28 & $\begin{array}{l}\text { Nemodificētas un termiski modificētas apses koksnes krāsu } \\
\text { izmaiņas } \Delta \text { Eab pēc } 40 \text { stundu ekspozīcijas dažāda veida } \\
\text { starojumiem }\end{array}$ & 87 \\
\hline 3.29. & $\begin{array}{l}\text { Nemodificētas un termiski modificētas apses koksnes atstarošanas } \\
\text { spektru izmaiņas pēc } 100 \text { stundu novecināšanas pilnā saulē un } \\
\text { kamerā UV starojumā }\end{array}$ & 88 \\
\hline 3.30 & $\begin{array}{l}\text { Termiski modificētas apses un baltalkšņa koksnes atstarošanas } \\
\text { izmaiņu atšķirības starp novecināšanu pilnā saules starojuma un UV } \\
\text { starojuma ietekmē }\end{array}$ & 88 \\
\hline 3.31 . & $\begin{array}{l}\text { Termiski modificētas un nemodificētas apses koksnes krāsas } \\
\text { izmaiņas } \Delta \text { Eab pēc koksnes } 100 \text { stundu ekspozīcijas dažādiem } \\
\text { saules spektra starojuma apgabaliem }\end{array}$ & 89 \\
\hline 3.32 . & $\begin{array}{l}\text { Termiski modificētas apses un baltalkšņa koksnes krāsu izmaiņas } \\
\text { UV starojuma un viḷņu garuma virs } 500 \mathrm{~nm} \text { ietekmē salīdzinot ar } \\
\text { pilna saules spektra izraisītām izmaiṇām }\end{array}$ & 90 \\
\hline 3.33. & $\begin{array}{l}\text { Nemodificētas un termiski modificētas }\left(170^{\circ} \mathrm{C}\right) \text { apses koksnes } \\
\text { atstarošanas spektru izmainas pēc koksnes } 100 \text { stundu ekspozīcijas } \\
\text { dažādiem saules starojuma spektra apgabaliem }\end{array}$ & 90 \\
\hline
\end{tabular}




\begin{tabular}{|c|c|c|}
\hline Nr. & Attēla nosaukums & Lpp. \\
\hline 3.34 & $\begin{array}{l}\text { Nemodificētas un termiski modificētas apses koksnes krāsas } \\
\text { izmaiṇas mākslīgās novecināšanas laikā UV un PC testos }\end{array}$ & 92 \\
\hline 3.35 & $\begin{array}{l}\text { Nemodificētas un termiski modificētas }\left(170^{\circ} \mathrm{C}\right) \text { apses koksnes } \\
\text { gaišuma parametra izmaiñas } \Delta \mathrm{L}^{*} \text { un krāsainības izmaiņas } \Delta \mathrm{C}^{*} \\
\text { mākslīgās novecināšana UV un PC testu laikā }\end{array}$ & 92 \\
\hline 3.36 & $\begin{array}{l}\text { Nemodificētas un termiski modificētas }\left(160 \text { un } 170^{\circ} \mathrm{C}\right) \text { apses } \\
\text { koksnes krāsas pirms un pēc mākslīgās novecināšanas UV un PC } \\
\text { testiem }\end{array}$ & 93 \\
\hline 3.37 & $\begin{array}{l}\text { Nemodificētas un termiski modificētas (TM 160; TM 170) apses } \\
\text { koksnes atstarošanas spektri pirms un pēc novecināšanas }\end{array}$ & 93 \\
\hline 3.38 . & $\begin{array}{l}\text { UV starojumam pakḷautas, ar fluoroglucīna šḳīdumu iekrāsotas } \\
\text { apses koksnes šḳêrsgriezuma attēls }\end{array}$ & 94 \\
\hline 3.39 & $\begin{array}{l}\text { Nemodificētas un termiski modificētas apses koksnes FTIR ATR } \\
\text { spektri pirms un pēc } 40 \text { stundu eksponēšanas dažādiem starojumiem }\end{array}$ & 95 \\
\hline 3.40 & $\begin{array}{l}\text { Termiski modificētas }\left(170^{\circ} \mathrm{C}\right) \text { un nemodificētas apses koksnes } \\
\text { absorbcijas izmaiņas viḷnu skaitlu } 1510 \mathrm{~cm}^{-1} \text { un } 1720 \mathrm{~cm}^{-1} \\
\text { apgabalos dažāâ starojumu iedarbības rezultātā }\end{array}$ & 96 \\
\hline 3.41 & $\begin{array}{l}\text { Termiski modificētas }\left(170^{\circ} \mathrm{C}\right) \text { un nemodificētas apses koksnes } \\
\text { procentuālais absorbcijas samazinājums } 1510 \mathrm{~cm}^{-1} \text { apgabalā pēc } \\
\text { paraugu } 40 \text { stundu apstarošanas ar dažāda veida starojumu }\end{array}$ & 96 \\
\hline 3.42 . & $\begin{array}{l}\text { Dažāâ saules starojuma spektra apgabalu izraisītās absorbcijas } \\
\text { spektru izmainas termiski modificētai }\left(170^{\circ} \mathrm{C}\right) \text { un nemodificētai } \\
\text { apses koksnei }\end{array}$ & 97 \\
\hline 3.43 & $\begin{array}{l}\text { Termiski modificētas }\left(170^{\circ} \mathrm{C}\right) \text { un nemodificētas apses koksnes } \\
\text { absorbcijas izmaiṇas viḷnu skaitḷu } 1510 \mathrm{~cm}^{-1} \text { un } 1720 \mathrm{~cm}^{-1} \\
\text { apgabalos dažāà saules starojuma spektru apgabalu iedarbības } \\
\text { rezultātā }\end{array}$ & 98 \\
\hline 3.44 & $\begin{array}{l}\text { Termiski modificētas }\left(170^{\circ} \mathrm{C}\right) \text { apses koksnes absorbcijas izmaiņu } \\
\text { dinamikas viḷ,nu skaiḷ } 1510 \mathrm{~cm}^{-1} \text { un } 1720 \mathrm{~cm}^{-1} \text { apgabalos koksnes } \\
\text { apstarošanas laikā ar UV starojumu mākslīgās novecināšanas } \\
\text { kamerā }\end{array}$ & 98 \\
\hline 3.45 & $\begin{array}{l}\text { Korelācija starp koksnes krāsas un k̦īmiskajām izmain̄ām, koksni } \\
\text { pakḷaujot dažādu saules spektra starojumu apgabaliem }\end{array}$ & 99 \\
\hline 3.46 & $\begin{array}{l}\text { Termiski modificētas }\left(170^{\circ} \mathrm{C}\right) \text { apses koksnes virsmas absorbcijas } \\
\text { izmainas pēc } 1000 \text { stundu apstarošanas ar UV starojumu un tai } \\
\text { sekojošas virsmas apsmidzināšanas ar ūdeni }\end{array}$ & 99 \\
\hline 3.47 & $\begin{array}{l}\text { Termiski modificētas apses koksnes SEM attēli } 50 \times \text { palielinājumāa } \\
\text { pirms mākslīgās novecināšanas, pēc } 720 \text { stundu apstarošanas ar UV } \\
\text { starojumu un pēc } 1000 \text { h PC novecināšanas. }\end{array}$ & 100 \\
\hline 3.48 & $\begin{array}{l}\text { Termiski modificētas }\left(170^{\circ} \mathrm{C}\right) \text { apses koksnes SEM attēli pirms tās } \\
\text { mākslīgās novecināšanas }\end{array}$ & 101 \\
\hline 3.49 . & $\begin{array}{l}\text { Termiski modificēta }\left(170^{\circ} \mathrm{C}\right) \text { apses koksnes SEM attēli pēc paraugu } \\
720 \text { stundu apstarošanas ar UV starojumu }\end{array}$ & 101 \\
\hline 3.50 & $\begin{array}{l}\text { Termiski modificētas }\left(170^{\circ} \mathrm{C}\right) \text { apses koksnes SEM attēli pēc } 1000 \\
\text { stundām pilnas mākslīgās novecināšanas }\end{array}$ & 102 \\
\hline 3.51 & $\begin{array}{l}\text { Termiski modificēta koksne ar plēvi neveidojošu pārklājumu SEM } \\
\text { attēli }\end{array}$ & 103 \\
\hline
\end{tabular}




\begin{tabular}{|c|c|c|}
\hline Nr. & Attēla nosaukums & Lpp. \\
\hline 3.52 & $\begin{array}{l}\text { Virsmas slapināššanas lenkisis (piecas sekundes pēc ūdens piliena } \\
\text { uzpilināšanas) dažādiem pārklājumiem }\end{array}$ & 104 \\
\hline 3.53 & $\begin{array}{l}\text { Uz nemodificētas (NM) un termiski modificētas (TM) apses } \\
\text { koksnes lietotu dažādu rūpniecisko un eksperimentālā pārklājuma } \\
\text { ūdens caurlaidība }\end{array}$ & 105 \\
\hline 3.54 & $\begin{array}{l}\text { Termiski modificētas koksnes ar dažādiem pārklājumiem ūdens } \\
\text { caurlaidības testā uzṇemtais un } 42 \text { dienu laikā nenožuvušais ūdens } \\
\text { daudzums }\end{array}$ & 106 \\
\hline 3.55 & $\begin{array}{l}\text { Plaisu vizuālā novērtējuma summārās vērtības termiski modificētai } \\
\left(170^{\circ} \mathrm{C}\right) \text { apses koksnei āra ekspozīcijas laikā }\end{array}$ & 106 \\
\hline 3.56 & $\begin{array}{l}\text { Termiski modificētas }\left(170^{\circ} \mathrm{C}\right) \text { apses koksnes krāsas izmainas āra } \\
\text { testā, pārklājumā izmantojot linsēklu ellıu un pernicu }\end{array}$ & 107 \\
\hline 3.57 . & $\begin{array}{l}\text { Attiecība (EPS-2/EPS-1) starp ar eksperimentāliem sastāviem } \\
\text { pārklātu koksnes paraugu ūdens caurlaidības un atsevišḳu } \\
\text { novecošanās rādītāju vērtībām }\end{array}$ & 108 \\
\hline 3.58 & $\begin{array}{l}\text { Nemodificētas un termiski modificētas }\left(170^{\circ} \mathrm{C}\right) \text { apses koksnes ar } \\
\text { dažādu virsmas apstrādi krāsas izmaiñas pēc } 2.5 \text { un } 100 \text { stundu } \\
\text { ekspozīcijas UV starojumam novecināšanas kamerā }\end{array}$ & 109 \\
\hline 3.59 & $\begin{array}{l}\text { Termiski modificētas }\left(170^{\circ} \mathrm{C}\right) \text { apses koksnes krāsa izmainas } \\
\text { mākslīgās novecināšanas kameras UV testa laikā }\end{array}$ & 111 \\
\hline 3.60 & $\begin{array}{l}\text { Termiski modificētas }\left(170^{\circ} \mathrm{C}\right) \text { apses koksnes bez pārklājuma krāsas } \\
\text { izmaiņas dažādos laikos realizētos āra testos }\end{array}$ & 114 \\
\hline 3.61 & $\begin{array}{l}\text { Plaisu salīdzinošs novērtējums pie } 160^{\circ} \mathrm{C} \text { un } 170^{\circ} \mathrm{C} \text { modificētas } \\
\text { koksnes paraugiem ar vienādiem pārklājumiem āra novecināšanas } \\
\text { laikā }\end{array}$ & 115 \\
\hline 3.62 & $\begin{array}{l}\text { Krāsu izmaiņas } \Delta \text { Eab āra testa laikā pie } 160^{\circ} \mathrm{C} \text { un } 170^{\circ} \mathrm{C} \\
\text { modificētas koksnes paraugiem ar vienādiem pārklājumiem }\end{array}$ & 116 \\
\hline 3.63. & $\begin{array}{l}\text { Pirmo mikroplaisu fiksēšanas laiks āra testā termiski modificētai } \\
\text { koksnei ar dažādiem pārklājumiem }\end{array}$ & 117 \\
\hline 3.64 & $\begin{array}{l}\text { Termiski modificētas koksnes ar dažādiem pārklājumiem krāsas } \\
\text { izmain̦as āra testā }\end{array}$ & 117 \\
\hline 3.65 & $\begin{array}{l}\text { Atstarošanas spektri termiski modificētai koksne ar un bez } \\
\text { pigmentiem }\end{array}$ & 118 \\
\hline 3.66. & $\begin{array}{l}\text { Krāsas izmaiṇas termiski modificētai koksnei ar dažāda sastāva } \\
\text { pigmentētiem pārklājumiem āra testā }\end{array}$ & 119 \\
\hline 3.67 & $\begin{array}{l}\text { Sarkano un dzelteno dzelzs oksīda pigmentu saturošu pārklājumu } \\
\text { plēvju gaismas caurlaidības spektri redzamās gaismas apgabalā }\end{array}$ & 119 \\
\hline 3.68 & Termiski modificētas koksnes krāsas izmaiņas $\Delta \mathrm{Eab}$ āra testā & 120 \\
\hline
\end{tabular}




\section{DARBA APROBĀCIJA}

\section{Publikācijas par darba tēmu}

1. D.Cirule, A.Meija-Feldmane, E.Kuka, B.Andersons, N.Kurnosova. A.Antons, H.Tuherm (2016) Spectral sensitivity of thermally modified and unmodified wood. Bioresources, 11(1), 324-335.

2. D.Cirule, E.Kuka (2015) Effect of thermal modification on wood colour. In: Proceedings of the Annual 21st International Scientific Conference Research for Rural Development 2015, Vol.2, 87-92.

3. D.Cirule, E.Kuka, A.Antons (2015) Disparity in discolouration of thermally modified wood exposed to solar and artificial ultraviolet irradiation. Rural Sustainability Research, 34(329), 12-20.

4. Meija-Feldmane A., Cîrule D., Kuka, E., Andersons, B. (2014) Colour changes of thermally modified hardwood under different conditions. In: Proceedings of the 10th meeting of the Northern European Network for Wood Science and Engineering (WSE) 2014, Edinburg, Scotland, 110-115.

5. Cirule D., Andersons B., Andersone I., Meija-Feldmane A., Grinins J. (2014) Weathering and protection of thermally modified aspen wood. In: Proceedings of the 3rd International Conference on Processing Technologies for the Forest and Biobased Products Industries (PTF BPI 2014), Kuchl/Salzburg, Austria, 241248.

6. Cirule D., Sansonetti E., Meija-Feldmane A., Andersone I., Andersons B. (2014) Coatings improving resistance of thermally modified wood to discoloration. In: Proceedings of the 10th Coatings Science International 2014, COSI 2014, Noordwijk, The Netherlands, 97-100.

7. Cirule D., Meija-Feldmane A., Kuka E. (2014) Colour stability of thermally modified hardwood In: Proceedings of the 20th Annual International Scientific Conference Research for Rural Development 2014, Jelgava, Latvia, Vol 2, 103108.

8. Andersone I., Andersons B., Irbe I., Čirkova J., Cīrule D., Kurnosova N,, Janberga A., Biziks V., Grīniņš J., Antons A. (2013) Termiski modificētas lapkoku koksnes ekspluatācijas īpašības. Vietējo resursu (zemes dzịlu, meža, pārtikas un transporta) ilgtspējīga izmantošana - jauni produkti un tehnoloǵijas (NatRes), Valsts pētījumu programma (2010-2013) rakstu krājums, Rīga, 2013, 162-165.

9. Sansonetti E., Cirule D., Grinins J., Andersone I., Andersons B. (2013) Colour changes in coated hydrothermally modified wood after artificial and outdoor exposure. In: Proceedings of the COST actions COST FP 0904 and COST FP 1006 conference Characterization of modified wood in relation to wood bonding and coating performance 2013, Rogla, Slovenia, 261-267.

10. Sansonetti E., Cirule D., Andersons B., Andersone I., Grinins J. (2013). Effect of outdoor exposure on coated thermally modified wood samples. In: Proceedings of the $9^{\text {th }}$ meeting of the Northern European Network for Wood Science and Engineering, 2013, Hannover, Germany, 197-201.

11. Andersons B. Andersone I., Irbe I., Cirule D., Biziks V., Grinins J., Sansonetti H. (2013). New products from deciduous wood by one-stage hydrothermal modification. Proceedings of the $4^{\text {th }}$ International Scientific Conference on Hardwood Processing (ISCHP 2013), Florence, Italy, 220-226.

12. Sansonetti E., Kapaca E., Cirule D. (2012). Comparison and evaluation of several industrial and experimental coatings: effects of artificial weathering. Proceedings 
of the 8th meeting of the Northern European Network for Wood Science and Engineering (WSE), Kaunas, Lithuania, 35-41.

13. Kapaca E., Cirule D., Grinins J., Bikovens O., Andersons B. (2011). Chemical changes of untreated and hydrothermally modified hardwood after artifical weathering. In: Proceedings of the 7th meetinbg of the Northern European Network for Wood Science and Engineering (WSE), 2011, Oslo, Norway, 3742.

14. D. Cīrule, A.Alksne, I.Lavnikoviča, J.Hrols (2009). Latvijas mīksto lapu koku (parastā apse, baltalksnis, melnalksnis) un to starpsugu hibrīdu (hibrīdapse, hibrīdalksnis) koksnes struktūras un fizikālo īpašību izvērtējums. Lapu koku audzēšanas un racionālas izmantošanas pamatojums, jauni produkti un tehnologijas. Valsts pētījumu programma, 2005-2009, Rakstu krājums, LVMI "Silava”, LLU Meža fakultāte, LV Koksnes ķīmijas institūts,70-73.

\section{Ziņojumi zinātniskajās konferencēs}

1. Cirule D., Meija-Feldmane A., Kuka E. Colour stability of thermally modified hardwood. The 20th Annual International Scientific Conference Research for Rural Development 2014, 20-22 May, Jalgava, Latvija (mutiskais zinojums).

2. Cirule D., Sansonetti E., Meija-Feldmane A., Andersone I., Andersons B. Coatings improving resistance of thermally modified wood to discoloration. The 10th International Scientific Conference Coatings Science International (COSI), 23-27 June, 2014, Noordwijk, The Netherlands (mutiskais ziņojums).

3. Cirule D., Andersons B., Andersone I., Meija-Feldmane A., Grinins J. Weathering and protection of thermally modified aspen wood. The 3rd International Conference on Processing Technologies for the Forest and Biobased Products Indystries (PTF BPI 2014), Kuchl/Salzburg, Austria, September 24-26, 2014 (mutiskais ziņojums).

4. Cirule D., Kuka E. Effect of thermal modification on wood colour. The 21th Annual International Scientific Conference Research for Rural Development 2015, Jelgava, May 13-15, 2015, Jelgava, Latvija (mutiskais ziņojums).

\section{Dalība projektos, kas saistīti ar promocijas darba tēmu}

1. Lapu koku audzēšanas un racionālas izmantošanas pamatojums, jauni produkti un tehnologijas. Valsts pētījumu programma, 2005-2009.

2. Vietējo resursu (zemes dzịlu, meža, pārtikas un transporta) ilgtspējīga izmantošana - jauni produkti un tehnoloğijas (NatRes). Valsts pētījumu programma, 2010-2013.

3. Inovatīvi koksnes un tās pārstrādes materiāli ar uzlabotām ekspluatācijas īpašībām. Eiropas Reǵionālās attīstības fonda projekts Nr.2010/0324/2DP/2.1.1.1.0/10/APIA/VIAA/057, 2010-2013.

4. Meža un zemes dzịḷ resursu izpēte, ilgtspējīga izmantošana - jauni produkti un tehnologijas (ResProd) Projekts Nr.3 „Biomateriāli un bioprodukti no meža resursiem ar daudzpusīgu pielietojumu". Valsts pētījumu programma, 20142017. 


\section{IEVADS}

Koksne izsenis ir bijusi plaši izmantots materiāls visdažādākajās dzīves sfērās no adatas līdz templim. Lai arī mūsdienās dạ̣ā no pielietojuma jomām to ir izkonkurējuši citi materiāli, tomēr, pateicoties savai dabiskajai izcelsmei, plašajai pieejamībai, relatīvi vienkāršajai un vieglajai mehāniskajai apstrādājamībai un augstajām īpatnējās stiprības īpašībām, koksne arī šodien tiek plaši lietota gan kā konstrukciju materiāls, gan dzīves telpas iekārtošanai. Un, ņemot vērā, ka viena no šodienas aktualitātēm ir ilgtspējīgas attīstības nodrošināšana, kas cieši saistīta ar centieniem arvien plašāk dzīves vidē izmantot no vietējiem, atjaunojamiem resursiem iegūtus un pēc kalpošanas termiņa beigām viegli utilizējamus materiālus, inovatīvi koksnes produkti, kas nodrošinātu plašāku tās izmantošanu, ir perspektīvs šī uzstādījuma risinājums.

Būtisks faktors, kas apgrūtina koksnes konkurētspēju ar citiem materiāliem un kavē vēl plašāku izmantošanu, īpaši būvniecībā, ir tās nenoturība pret apkārtējās vides iedarbību - formas un izmēru nestabilitāte main̄̄gā vides mitrumā, krāsas maiṇa saules starojuma ietekmē, virsmas erozija āra apstākḷıs, dažādu krāsojošo un trupes sēņu apdraudējums paaugstinātā mitrumā. Viens no veidiem, kā uzlabot koksnes īpašības, tai skaitā tās noturību pret vides faktoru iedarbību, ir koksnes modifikācija.

Pēdējo desmitgažu laikā ir palielinājusies interese par dažādām metodēm, kas, izmainot koksnes ķīmisko struktūru, l̦autu izmainīt dažādas koksnes īpašības, tādējādi padarot to piemērotāku noteiktās pielietojuma jomās (Tjeerdsma and Militz 2005). İpaši aktuāla koksnes modifikācija ir kḷuvusi apstākḷıs, kad daudzās Eiropas valstīs, tai skaitā arī Latvijā, arvien stingrāk tiek kontrolēta un ierobežota biocīdu lietošana, kas ilgstoši bijis galvenais paṇēmiens koksnes ilgizturības nodrošināšanai. Koksnes termiskās modifikācijas procesā, atšķirībā no dažādām koksnes ḳīmiskās modifikācijas metodēm, netiek izmantotas ķimikālijas. Termiskās modifikācijas procesā koksnes struktūra un īpašības izmainās koksnes ķīmisko komponentu autokatalītisku reakciju rezultātā, tādēl šī metode tiek uzskatīta par salīdzinoši videi draudzīgu koksnes modifikācijas metodi (Hill, 2006). Eiropā šobrīd vismaz 25 valstīs kopumā ir vairāk nekā 90 termiski modificētas koksnes ražotņu. Arī Latvijā tiek gan ražota (Stora Enso Launkalne, SIA Termowoodex), gan arī patērētājiem piedāvāta citu valstu ražotāju termiski modificēta koksne. Koksnes termiskās modifikācijas kapacitāte nepārtraukti aug, un 2015. gadā Eiropā saražoja ap 300,000 - 400,000 $\mathrm{m}^{3}$ termiski modificētas koksnes (Militz, 2015). Termiski modificētas koksnes ražotnes tiek attīstītas arī Ziemel̦amerikā, Austrālijā, Āzijā. Tā kā termiskās modifikācijas iekārtas ir relatīvi vienkāršas un to kapitālizmaksas ir zemas, ir visai ticams, ka koksnes termiskās modifikācijas apjomi varētu pieaugt arī turpmāk (Militz and Altgen, 2014).

Koksnes termiskās modifikācijas procesa rezultātā iegūtā materiāla īpašības ir atkarīgas gan no modifikācijas procesa parametriem - temperatūras, ilguma, vides, gan izmantotā materiāla, proti, koksnes - koka sugas, koksnes izejas mitruma, blīvuma. Mainot kādu no šiem faktoriem, iegūst materiālu ar citām īpašībām (Bekhta and Niemz, 2003; Esteves and Pereira, 2008; Chaouch et al., 2013). Tādēl, lai arī ir veikti plaši pētījumi par koksnes termisko modifikāciju un šāda koksne pēc vairākām metodēm tiek ražota arī rūpnieciskā mērogā, pasaulē joprojām notiek intensīvi pētījumi gan par pašiem termiskās modifikācijas procesiem un dažādu faktoru ietekmi uz izmaināām koksnē, gan par iegmodificētās koksnes īpašībām un tās pielietojamību.

Termiskās modifikācijas procesā iegūst tumšāk vai gaišāk brūnu koksni ar uzlabotu bionoturību un izmēru stabilitāti main̄̄gos vides mitruma apstākḷıs, bet vienlaicīgi ar zemākiem mehāniskās stiprības rādītājiem, kas ierobežo tās pielietošanu, kā nesošo konstrukciju materiālu. Līdz ar to termiski modificētas koksnes potenciālās 
pielietošanas jomas galvenokārt ir kā apdares un galdniecības materiāli - apšuvuma dēḷi, grīdu un terašu segumi, mēbeles, logu rāmji, durvis, saunu apdares u.c. (Yildiz et al., 2011; Militz and Altgen, 2014). Tās ir jomas, kurās materiāla dekorativitātes stabilitātei ir ḷoti liela nozīme. Pêtījumi par termiski modificētas koksnes dekoratīvajām īpašībām (piemēram, krāsas homogenitāte) un to stabilitāti dažādos apstākḷos ir fragmentāri. Ir zināms, ka termiski modificētai koksnei, tāpat kā nemodificētai koksnei, vides iedarbības rezultātā mainās gan virsmas krāsa, gan struktūra, un šie procesi termiski modificētai un nemodificātai koksnei ir atšķirīgi. Koksnes krāsa bieži vien ir viens no izšķirošiem argumentiem par labu tieši termiski modificētas koksnes izvēlei. Koksnei paredzētie virsmu nesedzošie pārklājumi, kuri termiski modificētas koksnes gadījumā varētu būt piemērotākie, jo tie nemaina koksnes krāsu, nav pietiekami efektīvi termiski modificētas koksnes dekorativitātes saglabāšanai ekspluatācijas laikā. Labāku rezultātu nodrošināšanai ir nepieciešami pārklājumi, kas veidoti, ņemot vērā termiski modificētas koksnes īpatnības.

Latvijā kokrūpniecībā tradicionāli nozīmīgākie ir skujkoki, kaut arī lapkoki aizṇem lielākās meža platības valstī (54\%), un izplatītākās lapkoku sugas pēc aizṇemtās platības ir bērzs $(27,9 \%)$, baltalksnis $(9,8 \%)$ un apse $(7,7 \%)$. Arī pēc kopējās koksnes krājas dominē lapkoki, turklāt lapkoku īpatsvars Latvijas mežos pēdējā laikā ir nemitīgi palielinājies (Meža nozare..., 2012). Pētījums par Latvijas koksnes resursiem ir parādījis, ka Latvijas mīksto lapkoku resursi netiek pietiekoši izmantoti un ir uzkrājušās lielas to rezerves (Krūmiņš u.c., 2013). Tas norāda, ka būtu svarīgi atrast plašākas vietējo lapkoku resursu izmantošanas iespējas, vēlams, radot jaunus produktus ar augstu pievienoto vērtību. Viens no šādiem produktiem varētu būt termiski modificēta koksne ar stabilām dekoratīvajām īpašībām.

Apkopojot literatūrā pieejamos teorētiskos un eksperimentālos datus par termiski modificētu koksni un koksnes pārklājumiem, ir izvirzītas promocijas darba pētnieciskā hipotēze.

Termiskās modifikācijas izraisītu ķīmisko pārvērtību rezultātā būtiski mainās koksnes novecošanās procesi, un to aizkavēšanai piemērotu pārklājumu optimālie sastāvi atšķiras no nemodificētai koksnei paredzētajiem.

Darbā ir izvirzīts pētnieciskais mērḳis.

Ar speciāli veidotiem plēvi neveidojošiem virsmas pārklājumiem uzlabot termiski modificētas lapkoku koksnes dekorativitātes noturību pret vides faktoru izraisītām pārmaiṇām.

Lai to veiktu, tika izvirzīti sekojoši pētnieciskie uzdevumi:

1. raksturot koksnes krāsas izmainu procesu dažādos termiskā modifikācijas režīmos un salīdzināt iegūtā materiāla un nemodificētas koksnes dekoratīvās īpašības;

2. noskaidrot termiski modificētas koksnes un vides faktoru mijiedarbības īpatnības;

3. izstrādāt termiski modificētai koksnei piemērotus, tekstūru nenosedzošus pārklājumus ar nepieciešamajām piedevām koksnes dekoratīvo īpašību saglabāšanai;

4. aprobēt un optimizēt pārklājumu sastāvus, veicot āra novecināšanas testus. 
Darba zinātniskā novitāte:

- noskaidrots koksnes krāsu veidojošo hromoforo grupu izmaiṇu raksturs termiskās modifikācijas procesā;

- noteikta koksnes krāsu veidojošo hromoforo grupu saistība ar koksnes ḳīmiskajiem komponentiem;

- veikta termiski modificētas koksnes krāsas homogenitātes un stabilitātes analīze;

- izpētītas termiski modificētas koksnes novecošanās procesu īpatnības;

- noskaidrota termiski modificētas koksnes gaismas spektrālā jutība;

- optimizēts termiski modificētai koksnei piemērotu, plēvi neveidojošu pārklājumu saistvielu komplekss;

- noskaidrotas termiski modificētas koksnes novecošanās aizkavēšanai piemērotas pārklājuma funkcionālās piedevas.

Darba praktiskā nozīme:

- zināšanas par koksnes krāsas veidošanos termiskās modifikācijas laikā palīdz pareizi plānot dekoratīvam lietojumam paredzētu koksnes materiālu modifikācijas procesu;

- darbā iegūtā informācija par termiski modificētas koksnes novecošanās īpatnībām l̦auj mērḳtiecīgi veidot efektīvus, ekonomiski un ekoloǵiski pamatotus pārklājumu sastāvus tās optimālai aizsardzībai pret vides faktoru iedarbību;

- izstrādāta termiski modificētas koksnes aizsardzībai un dekorativitātes saglabāšanai piemērota, plēvi neveidojoša pārklājuma kompozīcija ar paaugstinātu atjaunojama augu izcelsmes komponenta - linsēklu eḷ as īpatsvaru saistvielas sastāvā un optimizētu funkcionālo piedevu kvalitatīvo un kvantitatīvo sastāvu. 


\section{SITUĀCIJAS ANALĪZE (LITERATŪRAS APSKATS)}

\subsection{Koksnes termiskā modifikācija}

\subsubsection{Termiskās modifikācijas procesi}

Sava veida koksnes termiskā modifikācija, lai uzlabotu tās lietošanas īpašības, ir izmantota jau pirms daudziem gadu tūkstošiem (Rowell et al., 2009). Āfrikā, lai padarītu cietākus koka šḳēpu galus, tie tika apdedzināti. Pirms vairāk nekā pieciem tūkstošiem gadu sāmi ir lietojuši slēpes, kas bija liektas, izmantojot koksnes karsēšanu, bet viduslaikos vikingi apdedzināja koksni, lai uzlabotu tās noturību āra apstākḷos (Mayes et al., 2003). Savukārt senie romieši izmantoja koksnes termisku apstrādi, lai pagatavotu ozolkoka mucas vīna glabāšanai (Twede, 2006).

20.gs pirmajā pusē, veicot virkni pētîjumu, tika konstatēts, ka koksnes apstrāde paaugstinātā temperatūrā paaugstina tās dimensionālo stabilitāti, un 1942. gadā ASV tika patentēta koksnes pretrukšanas apstrādes metode (Antishrink treatment for wood). Tā paredzēja īslaicīgu $(10 \mathrm{~min}-1 \mathrm{~h})$ koksnes apstrādi augstās temperatūrās $\left(260^{\circ} \mathrm{C}-315^{\circ} \mathrm{C}\right)$, kas, saskaņā ar patentu, nodrošina līdz 50 \% lielu koksnes pretuzbriešanas efektivitāti (Stamm, 1942). Koksni, kuras dimensionālā stabilitāte tika uzlabota, to termiski apstrādājot pie temperatūrām, kas bija ievērojami augstākas par tradicionāli koksnes žāvēšanai izmantotajām, nosauca par "Staybwood". Turpmākajos pētījumos tika konstatēts, ka termiskās apstrādes rezultātā paaugstinātā koksnes hidrofobitāte gan palielina tās dimensionālo stabilitāti un biorezistenci, bet vienlaicīgi šāda apstrāde būtiski samazina koksnes mehānisko izturību. Turklāt tika novērots, ka mazāki stiprības zudumi pie vienāda pretuzbriešanas efekta ir, ja koksni apstrādā bez gaisa piekḷuves, kas tika realizēts, kā modifikācijas vidi izmantojot izkausētu metālu sakausējumu (Stamm et al., 1946). Pagājušā gadsimta otrajā pusē virkne pētījumu par koksnes termisko modifikāciju tika veikti Vācijā (Burmester, 1973; Giebeler, 1983). Šo pētījumu rezultātā tika izveidoti komerciāli koksnes termiskās modifikācijas procesi "Lignostone" un "Lignifol", bet tie netika realizēti vērā ņemamos ražošanas apjomos.

Interese par koksnes termisko modifikāciju atjaunojās 20.gs. beigās, kad aktualizējās nepieciešamība pēc alternatīviem koksnes bioizturības uzlabošanas paņēmieniem, jo līdz tam lietotie aizsardzības līdzekḷi to toksiskuma dēḷ tika aizliegti. Tad arī Eiropā izstrādāja un komercializēja vairākus koksnes termiskās modifikācijas procesus. Kopējais 2015. gadā Eiropā saražotais termiski modificētas koksnes apjoms tiek lēsts ap 300,000 - 400,000 m³ (Militz, 2015).

Koksnes modifikāciju definē kā procesu, kura rezultātā koksne tiek pārvērsta jaunā materiālā ar uzlabotām īpašībām (Hill, 2006). Koksnes termiskajā modifikācijā jauns produkts ar uzlabotām īpašībām tiek iegūts, pakḷaujot koksni augstas temperatūras iedarbībai bez ķimikāliju pielietošanas, kas l̦auj to uzskatīt par ekoloǵiski draudzīgu alternatīvu impregnēšanai ar ķimikālijām (Korkut and Guller, 2008). Reizēm koksnes termiskā modifikācija tiek izmantota, lai, izmainot koksnes krāsu, paplašinātu tās tirgu un pat izmantotu to kā tropisko kokšņu aizstājēju (Widman et al., 2012).

Ir izstrādātas ap 30 dažādas koksnes termiskās modifikācijas tehnologiijas (Hofmann et al., 2013). Tām visām kopēja ir koksnes apstrāde vidē ar ierobežotu skābekḷa daudzumu pie temperatūrām $\left(130-240^{\circ} \mathrm{C}\right)$, kas ir augstākas, nekā tradicionāli koksnes žāvēšanai lietotās. Modifikācijas veidi atšķiras ar procesa tehnoloǵiskajiem parametriem: temperatūru, vidi, spiedienu, apstrādes ilgumu, lietotā izejmateriāla mitrumu un izmēriem. Termisko modifikāciju var veikt slēgtā vidē, kad koksnes termiskās destrukcijas produkti paliek modifikācijas telpā, vai atvērtā vidē, kad gāzveida 
destrukcijas produkti tūlīt pēc to izveidošanās visu modifikācijas laiku tiek aizvadīti no modifikācijas vides (Arnold, 2007).

Šobrīd rūpnieciski vislielākie termiski modificētas koksnes apjomi tiek saražoti saskaņā ar Somijā izstrādāto "ThermoWood" procesu. Tā pamatā ir atvērtā reaktora process, kurā skābekḷa ierobežošanai un siltuma pievadīšanai tiek izmantota pārkarsēta tvaika plūsma pie atmosfēras spiediena, kas vienlaicīgi no modifikācijas vides aiznes destrukcijas produktus. "ThermoWood" process sastāv no trīs fāzēm: sākuma fāzē notiek koksnes žāvēšana $\left(130^{\circ} \mathrm{C}\right)$, seko pati termiskās modifikācijas fāze, kas, atkarībā no iegūstamā produkta paredzamā pielietojuma, tiek realizēta $185-230^{\circ} \mathrm{C}$ temperatūrā; process noslēdzas ar atdzesēšanas un koksnes rekondicionēšanas fāzi, kuras laikā tiek nodrošināts, lai koksnes mitrums sasniegtu vismaz 4 - 6\% (Mayes et al., 2003).

Francijā ir izstrādāti divi termiskās modifikācijas procesi. Retifikācijas (Retification) procesā modifikācijai izmanto žāvētu koksni (mitrums ap 12\%), process notiek slāpekḷa atmosfērā, un koksne tiek karsēta $180-250^{\circ} \mathrm{C}$ temperatūrā. Otrs process ir "Le Bois Perdure" process, kurā izmanto nežāvētu koksni, un process tiek realizēts piesātināta ūdens tvaika atmosfērā, kurā ūdens tvaiks daļēji tiek iegūts no koksnes, tai žūstot. Šajā procesā modifikācija notiek 200 - 230 ${ }^{\circ} \mathrm{C}$ temperatūrā (Rapp, 2001; Hill, 2009). Nīderlandē ir patentēts "Plato Wood" koksnes termiskās modifikācijas process, kas sastāv no vairākām stadijām - hidrotermiskas koksnes apstrādes piesātināta tvaika vidē $160-190^{\circ} \mathrm{C}$ temperatūrā, tai sekojošas koksnes žāvēšanas (3 - 5 dienas) un noslēdzošās fāzes, kuras laikā sausā koksne tiek apstrādāta pie atmosfēras spiediena ūdens tvaika vai sakarsēta gaisa vidē $170-190^{\circ} \mathrm{C}$ temperatūrā. Šajā fāzē notiek hidrolīzes fāzē izmainīto koksnes polimērkomponentu rekombinācija un kondensācija. Vēl viens Nīderlandē izstrādāts un patentēts process ir koksnes hidrotermiskās modifikācijas process "Firmolin" (Willems, 2008). Tas ir slēgta reaktora tipa process, kurā koksnes modifikācija notiek pie paaugstināta spiediena ūdens tvaika vidē $130-220^{\circ} \mathrm{C}$ temperatūrā. Šajā procesā netiek piel̦auta koksnes pilnīga izžūšana, tādējādi izvairoties no stresiem, kas rodas koksnē gan žāvēšanas, gan atkal līdzsvara mitruma atgūšanas procesā. Līdzīgs princips ir pamatā Dānijā WTT (Wood Treatment Technologies) izstrādātajam procesam (Skwomand and Christensen, 2003). Vācijā ir attīstīts OHT (Oil Heat Treatment) process, kurā koksnes karsēšana notiek augu eḷ,āa, kas nodrošina zemu skābekḷa saturu reakcijas vidē un labu siltumapmaiṇu. Modifikācija notiek $180-220^{\circ} \mathrm{C}$ temperatūrā slēgta reaktora procesā (Rapp, 2001). Ir izstrādātas un ražošanā ieviestas vairākas koksnes termiskās modifikācijas tehnologijas, kurās procesa vide ir vakuums. Vakuumā modificētas koksnes atšķiras ar to, ka tām nav termiski modificētai koksnei raksturīgais nepatīkamais aromāts. "Vacu ${ }^{3 "}$ ir termiski modificēta koksne, kura ražota saskaņā ar vakuuma-spiediena atūden,ošanas metodi (Vacuum-press dewatering method), kurā koksne tiek sildīta, izmantojot karsēšanas plates, kas nodrošina augstu siltuma pārneses efektivitāti. Savukārt vakuums nodrošina efektīvu degradācijas produktu aizvākšanu no modifikācijas vides (Hofmann et al., 2013). Līdzīga ir arī termiski modificētas koksnes ar nosaukumu "SmartHeat" ražošanas tehnologiija. Itālijā ir attīstīts koksnes termiskās modifikācijas process vakuumā "TERMOVUOTO", kas ir sauss process atvērtā sistēmā, kur radušās gaistošās vielas un ūdens tvaiki nepārtraukti tiek aizvadīti no modifikācijas vides (Pagnozzi, 2012).

Hidrotermiskā modifikācija slēgtā sistēmā piesātināta ūdens tvaika vidē ḷauj veikt koksnes termisko modifikāciju pie salīdzinoši zemākām temperatūrām, kas padara šo procesu ekonomiskāku (Dagbro et al., 2010; Karlsson et al., 2012). Šajā procesā koksnes modifikācija notiek pie zināma gaisa relatīvā mitruma, kas ir atkarīgs gan no procesa temperatūras, gan spiediena, ko savukārt ietekmē no koksnes iztvaikojošais ūdens, kā arī gāzveida organiskie koksnes destrukcijas produkti. Tā kā apkārtējās vides spiediens 
nosaka vielu viršanas temperatūru un līdz ar to ūdens un citu organisko komponentu iztvaikošanu no koksnes, termiskajā modifikācijā slēgta tipa sistēmā gan ūdens, gan citu organisko komponentu koncentrācija koksnē lielā mērā ir atkarīga no konkrētā spiediena (Altgen and Militz, 2015). Šādos apstākḷlos etiķskābe, kas rodas no hemicelulozēm, atšḳeḷoties acetilgrupām, darbojas kā polisaharīdu hidrolīzes katalizators, kas rezultātā paātrina koksnes modifikācijas procesu (Sundqvist et al., 2006). Šādā procesā koksne paaugstinātā temperatūrā neizžūst, un tā visu procesa laiku satur zināmu daudzumu mitruma (Hillis, 1984). Ir konstatēts, ka, pieaugot koksnes mitrumam, palielinās termiskās degradācijas reakciju ātrums un samazinās temperatūra, pie kuras šīs reakcijas sākas (Borrega and Kärenlampi, 2008a). Koksnes termiskās degradācijas ātrums mitrā koksne var būt pat desmit reizes lielāks nekā sausā koksnē (Skaar, 1988). Rezultātā, pie vienādas temperatūras masas zudumi termiskās degradācijas dēl ir daudz lielāki pie augstāka vides relatīvā mitruma (Lenth and Kamke, 2001; Borrega and Kärenlampi, 2008b). Intensīvāka termiskā degradācija pie paaugstināta mitruma tiek skaidrota arī ar faktu, ka šādos apstākḷos amorfo koksnes komponentu mīksttapšana jeb pāreja no stiklveida uz gumijveida stāvokli sākas pie zemākām temperatūrām (Hillis, 1984; Engelund et al., 2013). Sausā koksnē hemiceluložu mīksttapšanas temperatūra ir ap $170^{\circ} \mathrm{C}$ un lignīna - ap $215^{\circ} \mathrm{C}$, bet nežāvētā koksnē attiecīgi ap $80^{\circ} \mathrm{C}$ un $100^{\circ} \mathrm{C}$ (Hillis and Rozsa, 1985). Savukārt koksnes termiskā mīksttapšana nodrošina koksnes polimēru mobilitāti un līdz ar to zemāku aktivācijas enerǵiju, kāda nepieciešama, lai ierosinātu ķīmiskos procesus (Borrega and Kärenlampi, 2008a). Arī siltuma pārneses process salīdzinoši ātrāks ir mitrā, nekā sausā koksnē (Hillis, 1984). Turklāt, veicot koksnes termisko modifikāciju pārkarsēta tvaika atmosfērā, kā tas notiek, piemēram, ThermoWood procesā, koksne modifikācijas laikā tiek pilnībā izžāvēta, un pirms lietošanas tā ir jārekondicionē līdz noteiktam mitruma līmenim, kas papildus sadārdzina modifikācijas procesu (Rautkari and Hill, 2014).

\subsubsection{Koksnes izmaiṇas termiskās modifikācijas procesā}

Koksnes termiskās modifikācijas rezultāts ir atkarīgs gan no izmantotā izejmateriāla, gan modifikācijas procesa veida (slēgta, atvērta sistēma) un konkrētajiem apstrādes parametriem - temperatūras, spiediena, apstrādes ilguma, vides mitruma (Borrega and Kärenlampi, 2008a; Esteves and Pereira, 2008; Chaouch et al., 2013; Rautkari et al., 2013; Sandberg et al., 2013; Altgen and Militz, 2015). Galvenokārt atšķirīgā ķīmiskā sastāva dẹl, atšķirīgs rezultāts ir gan vienādos apstākḷos modificējot skujkokus un lapkokus, gan starp dažādām koku sugām (Boonstra et al., 2007; Chaouch et al., 2010; Ferrari et al., 2013b). Arī pat viena koka ietvaros izmaiņas, kādas termiskās modifikācijas laikā notiek ar juvenilo koksni, kam raksturīgs augstāks hemiceluložu un zemāks celulozes saturs, atškikiras no izmaiṇām, kādas tādos pašos modifikācijas apstākḷıs notiek ar brieduma koksni (Hillis, 1984; Nazerian et al., 2011; Severo et al., 2012). Savukārt pētījumos, kuros salīdzinātas vienādos apstākḷlos modificēta aplieva un kodolkoksne, novērots, ka ievērojami lielākas izmaiņas notiek ar kodolkoksni, kas tiek skaidrots ar atšķirīgo ķīmisko sastāvu un tieši salīdzinoši augsto ekstraktvielu saturu kodolkoksnē (Ishikawa et al., 2004; Ferrari et al., 2013a). Atšķirīgu rezultātu var iegūt arī atkarībā gan no modifikācijai izmantotās koksnes izejas mitruma, gan temperatūras celšanas ātruma (Johansson, 2006). Tāpat modifikācijas rezultāts var atšķirties atkarībā no apstrādājamā materiāla dimensionālajiem izmēriem, jo temperatūru materiāla iekšienē ietekmē eksotermisko reakciju radītais siltums un radušos gaistošo savienojumu izraisītais spiediens (Turner et al., 2010). Arī dēlu sakrāvums var ietekmēt modificēto 
materiālu, jo malējo un centrālo dēḷu temperatūra procesa laikā var būtiski atšḳirties (Perré et al., 2013). Tomēr galvenās, raksturīgākās izmaiṇas ir līdzīgas visiem termiskās modifikācijas procesiem un modificētajām koksnēm.

Masas zudumi. Viena no raksturīgākajām koksnes izmainām termiskās modifikācijas procesā ir koksnes masas zudumi, kas bieži tiek izmantoti, lai raksturotu termiskās modifikācijas intensitāti (Welzbacher et al., 2007; Borrega and Kärenlampi, 2008b; Chaouch et al., 2010). Koksnes masas zudumi ir atkarīgi no procesa temperatūras, ilguma, apstākḷiem (Andersons et al., 2010; Allegretti et al., 2012). Masas zudumus salīdzinoši vairāk ietekmē procesa temperatūra, nekā procesa ilgums (Welzbacher et al., 2007; González-Peña et al., 2009; Tuong and Li, 2010). Ir atklāts, ka, veicot koksnes termisko modifikāciju pie augstākām temperatūrām, līdzīgas īpašības (biologisko izturību, dimensionālo stabilitāti) var sasniegt pie mazākiem masas zudumiem (Welzbacher et al., 2007). Turklāt, paildzinot procesu, masas zudumi vairs nav tik strauji kā sākumā, kas tiek skaidrots ar hemiceluložu depolimerizācijas fāzei sekojošu repolimerizāciju un kondensāciju lignīna molekulā, kā rezultātā izveidojas struktūras ar paaugstinātu termoizturību (González-Peña et al., 2009). Ir noskaidrots, ka termiskās modifikācijas procesā, kas tiek realizēts ūdens tvaika vidē pie paaugstināta spiediena, līdzīgi masas zudumi rodas pie daudz zemākām temperatūrām nekā procesā, kurā izmanto pārkarsētu tvaiku (Rautkari and Hill, 2014). Savukārt, veicot pētījumus slēgta tipa sistēmā, ir konstatēts, ka masas zudumus vairāk ietekmē spiediens nekā apstrādes temperatūra (Altgen and Militz, 2015). Procesa sākumā pie zemākām temperatūrām masas zudumi galvenokārt ir saistīti ar ūdens un ekstraktvielu izvadīšanu no koksnes (Hill, 2006; Chaouch et al., 2013). Tomēr lielākie masas zudumi termiskās modifikācijas procesos galvenokārt tiek saistīti ar koksnes polisaharīdu frakcijas samazināšanos (González-Peña et al., 2009; Allegretti et al., 2012). Vienādos modifikācijas apstākḷos lielāki masas zudumi ir lapkoku koksnei, kas tiek skaidrots ar atšķirīgajām hemicelulozēm un ievērojami lielāku acetilgrupu saturu lapkoku koksnē (Rowell et al., 2009; Chaouch et al., 2010; Ferrari et al., 2013b). Tāpat ir konstatēts, ka vienādos apstākḷos lielāki masas zudumi ir blīvākai koksnei (Chaouch et al., 2010).

Struktūras izmainas. Veicot termiski modificētas koksnes struktūras pētījumus ar dažādām mikroskopijas tehnikām, ir konstatēts, ka termiskā modifikācija izraisa zināmus koksnes anatomisko elementu bojājumus un deformācijas. Ir izteikta arī hipotēze, ka koksnes struktūras bojājumi daḷēji varētu būt saistīti ar termiski modificētas koksnes vājākām mehāniskajām īpašībām (Boonstra et al., 2006a; Boonstra et al., 2006b; Awoyemi and Jones, 2011; Welzbacher et al., 2011). Pētījumi ir parādījuši, ka struktūras izmaiņas ir atkarīgas gan no koksnes sugas, gan modifikācijas procesa parametriem (Boonstra et al., 2006b). Parasti struktūras izmaiņas vairāk skar plānsienu elementus agrīnās koksnes traukus (lapkokiem), traheīdas (skujkokiem), serdes starus. Ir novērotas radiālas un tangenciālas plaisas, kā arī šūnu sieninu pārrāvumi perpendikulāri to garenvirzienam. Pretrunīgi rezultāti ir iegūti, novērojot poru membrānu izmaiņas modifikācijas rezultātā. Ir novērota poru deaspirācija, kas izpaužas kā šīs poras slēdzošo torusu plīšana (Awoyemi and Jones, 2011; Dashti et al., 2012; Ahmed et al., 2013a). Citos pētījumos ir iegūti pretēji rezultāti - poru membrānas nav skartas (Boonstra et al., 2006a). Termiskās modifikācijas rezultātā var arī veidoties gan virsmas, gan slēptās makroplaisas, ko ietekmē temperatūras celšanas ātrums un ar to saistîtais stresu veidošanās un izlīdzināšanās process, materiālam žūstot (Johansson, 2006).

Kīmiskās izmaiṇas. Termiskā modifikācija izraisa ievērojamas pārmainas koksnes ķīmiskajā struktūrā (Weiland and Guyonnet, 2003; Tjeerdsma and Militz, 2005; Yildiz et al., 2011; Bächle and Zimmer, 2012). Koksnes pamatkomponentu - celulozes, 
hemiceluložu, lignīna termiskās modifikācijas pamatā galvenokārt ir trīs ķ̄īmiskās reakcijas: hidrolīze, dehidratācija un šķērssaistīšanās, kuru norise variē atkarībā no modifikācijas apstākḷiem (Fengel and Wegener, 1989). Ķ̄imiskās reakcijas molekulu funkcionālo grupu līmenī notiek līdzīgi visām koku sugām visos termiskās modifikācijas procesos, kas nozīmēe, ka, variējot procesu parametrus, var sasniegt līdzīgus rezultātus (Willems et al., 2015). Tomēr konkrētās ḳīmiskās izmainas var ievērojami variēt atkarībā no izmantotās modifikācijas metodes un apstākḷiem, un literatūrā atrodamie rezultāti reizēm ir visai pretrunīgi.

Skatoties uz koksnes elementsastāva izmain̄ām, termiski modificētai koksnei ir raksturīga samazināta skābekḷa-oglekḷa (O/C) attiecība (Gérardin et al., 2007; Windeisen et al., 2007; Chaouch et al., 2010; Willems et al., 2013; Willems, 2014). Relatīvais skābekḷa daudzuma samazinājums norāda uz skābekli saturošu funkcionālo grupu (karboksil-, acetil-, hidroksilgrupu) daudzuma samazināšanos modifikācijas rezultātā.

Termiskās modifikācijas procesā izdalās gaistoši organiskie savienojumi (GOS), kas rodas, atbrīvojoties mazmolekulāriem savienojumiem no koksnes pamatkomponentiem, kā arī koksnes ekstraktvielu sadalīšanās rezultātā. Tomēr lielākais GOS daudzums termiskās modifikācijas procesā rodas, sadaloties koksnes pamatkomponentiem - polisaharīdiem un lignīnam (Windeisen et al., 2007; Ahajji 2009; Heigenmoser et al., 2013). Procesa laikā emitēto vielu daudzumu un to kvalitatīvo saturu var ietekmēt gan procesa temperatūra un ilgums, gan termiskajai apstrādei pakḷautā koku suga (Graf et al., 2005). Kopumā koksnes termiskās apstrādes procesa laikā radušos GOS kvalitatīva analīze ir uzrādījusi gandrīz 100 dažādus kīmiskos komponentus, tomēr apmēram $80 \%$ no kopējā daudzuma sastādīja etiķskābe, furfurols un furfurilatvasinājumi (Graf et al., 2005). Mazākā daudzumā emisijas gāzēs ir konstatēts arī metanols, skudrskābe, propionskābe, svek̦skābes, kā arī daži lignīna atvasinājumi. Skujkoku gadījumā termiskās modifikācijas izmešu gāzēs ir arī liels daudzums terpēnu, kas izskaidro samazināto terpēnu izdalīšanos no koksnes pēc termiskās modifikācijas, salīdzinot ar nemodificētu koksni (Hyttinen et al., 2010). Termiskās modifikācijas rezultātā mainās arī no koksnes ekspluatācijas laikā emitēto GOS ķīmiskais sastāvs un daudzums, un ir novērots, ka termiski modificēta koksne kopumā izdala daudz mazāk GOS, nekā tradicionāli žāvēta koksne.

Termiskās modifikācijas laikā no koksnes pamatkomponentiem ātrāk degradējas hemicelulozes, kas ir no polisaharīdu molekulām sastāvoši, sazaroti, amorfi polimēri (Windeisen et al., 2007; Brito et al., 2008; Zakis, 2008; Rowell et al., 2009; Mehrotra et al., 2010). Hemiceluložu salīdzinoši vājā termiskā stabilitāte tiek saistīta ar to amorfo struktūra un relatīvi nelielo molekulmasu (González-Peña et al., 2009). Turklāt hemiceluložu makromolekulām ir raksturīgs ievērojams acetilgrupu daudzums, un īpaši daudz acetilgrupu ir lapkoku koksnē. Ir konstatēts, ka koksnes termiskā degradācija sākas ar hemiceluložu acetilgrupu atšķelšanos, veidojot etiķskābi (Bhuiyan et al., 2000; Wikberg and Maunu, 2004; Tjeerdsma and Militz, 2005; Esteves et al., 2008a). Tādē vienādos termiskās modifikācijas apstākḷıs lielākas izmaiņas ir vairāk acetilgrupas saturošajai lapkoku koksnei, salīdzinājumā ar skujkoku koksni (González-Peña et al., 2009). Tālākā procesā etiķskābe darbojas kā polisaharīdu depolimerizācijas katalizators hidrolīzes reakcijās, kas galvenokārt skar amorfos polisaharīdus. Tas pazemina polisaharīdu polimerizācijas pakāpi, un rodas mazmolekulāri fragmenti - mono- un disaharīdi, kas ir viens no cēloṇiem augstajam ūden̄̄ šḳistošo ekstraktvielu saturam termiski modificētā koksnē. Tālākā termiskās apstrādes rezultātā notiek hidrolizēto cukuru dehidratācijas reakcijas, kurās, atšķeļoties ūdenim, veidojas furāni (pieclocekḷu heterocikliskie savienojumi ar skābekḷa atomu): no heksozēm veidojas hidroksimetilfurfurols un no pentozēm - furfurols (Nuopponen et al., 2004a; Tjeerdsma 
and Militz, 2005; Esteves et al., 2008a). Ir konstatēts, ka dehidratācijas produkti polikondensācijas reakcijās dal̦ēji saistās ar koksnes šūnu sieninuu pamatkomponentiem (Willems et al., 2013). Hemiceluložu degradācijas rezultātā termiski modificētā koksnē samazinās ar polisaharīdiem saistīto hidroksilgrupu daudzums, kas tiek saistīts ar tās augstāku hidrofobitāti (Weiland and Guyonnet, 2003; Inari et al., 2007). Savukārt modifikācijas laikā radušās organiskās skābes nosaka salīdzinoši zemo termiski modificētās koksnes pH (Sundqvist et al., 2006; Windeisen et al., 2007; Yao et al., 2012).

Celuloze, kas pēc savas ḳīmiskās uzbūves, līdzīgi kā hemicelulozes, ir polisaharīds, termiski ir daudz stabilāka, kas tiek skaidrots ar tās strukturālo organizētību mikrofibrilās un augsto kristāliskuma pakāpi (Li et al., 2005). Tomēr termiski modificētai koksnei ir konstatēta ievērojama, līdz pat 50\% liela, celulozes polimerizācijas pakāpes samazināšanās, kas varētu būt saistīta ar etiksskābes katalizētu hidrolīzi un tieši ietekmēt termiski modificētas koksnes stiprības samazināšanos (Sjöström, 1993). Lai arī celuloze temperatūrās, kādās parasti notiek koksnes termiskā modifikācija, ir stabila, tomēr termiski modificētas koksnes ekstraktvielās ir konstatēts levoglikozāns, kas ir celulozes termiskās destrukcijas produkts (Esteves et al., 2008a, Esteves et al., 2011). Ir arī konstatēts celulozes kristāliskuma pieaugums termiskās modifikācijas rezultātā, kas parasti tiek saistìts ar amorfo celulozes regiionu degradāciju termiskās modifikācijas procesā (Wikberg and Maumu, 2004; Tuong and Li, 2010; Huang et al., 2013). Celulozes kristāliskuma palielināšanās tiek skaidrota arī ar iespējamu kvazi-kristālisko amorfo reǵionu kristalizēšanos, pārkārtojoties vai pārorientējoties celulozes molekulām šajos rajonos (Bhuiyan et al., 2000).

Tiek uzskatīts, ka lignīns ir termiski stabilākais koksnes pamatkomponents (Hill, 2006). Termiskās modifikācijas rezultātā pieaug relatīvais lignīna saturs koksnē, kas galvenokārt ir saistīts ar koksnes polisaharīdu degradāciju koksnes termiskās apstrādes laikā (Nuopponen et al., 2004a; Windeisen et al., 2007; Brito et al., 2008; Huang et al., 2013). Tomēr arī ar lignīnu notiek pārmaiņas, un pētījumi ir parādījuši, ka lignīna modifikācija koksnes termiskās apstrādes laikā var sākties jau pie relatīvi zemām temperatūrām, proti, ap $120^{\circ} \mathrm{C}$ (Funaoka et al., 1990). Hemiceluložu termiskās degradācijas rezultātā atbrīvotā etiķskābe varētu būt veicinošs faktors lignīna degradācijai, kas galvenokārt notiek, šḳeḷoties aril-alkil-ētera saitēm (Wikberg and Maunu, 2004; Heigenmoser et al., 2013). Šḳeloties saitēm, lignīna molekulā rodas reakcijspējīgas vietas, kas veicina lignīna autokondensāciju, kā rezultātā veidojas relatīvi lielas šḳērssaistītas lignīna struktūras (Weiland and Guyonnet, 2003; Nuopponen et al., 2004a; Tjeerdsma and Militz, 2005; Boonstra and Tjeerdsma, 2006; Windeisen and Wegener, 2008; Yao et al., 2012). Ar lignīna degradāciju termiskās modifikācijas procesā ir saistīts arī relatīvi stabilo fenoksilradikāḷu koncentrācijas pieaugums termiski modificētā koksnēe, kuru koncentrācija palielinās, paaugstinot koksnes apstrādes temperatūru (Deka and Petrič, 2008; Ahajji et al., 2009).

Termiski modificētai koksnei, salīdzinot ar nemodificētu koksni, ir raksturīgs paaugstināts ekstraktvielu saturs, bet tas tā nav vienmēr, un ekstraktvielu daudzums būtiski atšķiras atkarībā gan no koka sugas, gan modifikācijas apstākḷiem (Hakkou et al., 2006; Brito et al., 2008). Termiskās modifikācijas laikā lielākā daļa nemodificētai koksnei raksturīgo ekstraktvielu tiek aizvadītas no koksnes, tām pārvēršoties par gaistošiem savienojumiem un iztvaikojot vai izskalojoties (Nuopponen et al., 2003; Esteves et al., 2008a; Militz and Altgen, 2014). Jau pie nelieliem masas zudumiem, kas raksturīgi salīdzinoši maigiem termiskās modifikācijas apstākḷiem, ekstraktvielu sastāvā palielinās fenolisko komponentu īpatsvars, kas norāda uz lignīna degradāciju, kā rezultātā veidojas mazmolekulāri savienojumi (Kamdem et al., 2000; Nuopponen et al., 2004a; Ahajji et al., 2009; Niemz et al., 2010; Esteves et al., 2011; Hofmann et al., 2013). 
Modifikācijas apstākḷiem kḷūstot bargākiem, palielinās kā lignīna, tā arī ogḷūdeṇražu izcelsmes ekstraktvielu daudzumi. Ne vienmēr ir viegli noteikt ekstraktvielu izcelsmes avotu, jo aromātiski destrukcijas produkti var veidoties ne tikai no lignīna, bet zināmos apstākḷıs arī polisaharīdu degradācijas rezultātā (Nuopponen et al., 2004a). Ir novērots, ka, sasniedzot zināmu koksnes termiskās destrukcijas pakāpi, ekstraktvielu saturs koksnē atkal samazinās, kam par iemeslu varētu būt daḷas termiskās modifikācijas procesā radušos mazmolekulāro koksnes destrukcijas produktu tālāka degradācija pie paaugstinātām temperatūrām, pārvēršoties gaistošos savienojumos, kā arī iesaistīšanās intensīvās lignīna šķērssaistǐšanās reakcijās (Nuopponen et al., 2004a; Esteves et al., 2008a; Peters et al., 2008; Esteves et al., 2011). Toksikoloǵiskie testi ir parādījuši, ka termiskās modifikācijas rezultātā radušās ekstraktvielas nav ar paaugstinātu toksiskumu, salīdzinot ar no nemodificētas koksnes ekstraǵētām vielām (Esteves et al., 2011).

Fizikālo raksturlielumu izmaiṇas. Termiskās modifikācijas rezultātā samazinās koksnes blīvums un, jo bargāki modifikācijas apstākḷi, jo samazinājums lielāks (Johansson, 2008; González-Peña et al., 2009; Molinski et al., 2010; Widman et al., 2012). Turklāt konstatēts, ka juvenilās koksnes blīiums samazinās vairāk nekā brieduma koksnes blīvums (Nazerian et al., 2011). Termiskās modifikācijas rezultātā mainās arī koksnes šūnu sieniņu blīvums, bet rezultāti nav viennozīmīgi. Ir konstatēta gan šì radītāja samazināšanās, gan palielināšanās pie dažādām modifikācijas temperatūrām. Arī attiecībā uz koksnes porainības izmaiņām termiskās modifikācijas procesā nav viennozīmīgu rezultātu (Pfriem et al., 2009; Zauer et al., 2013).

Viena no būtiskākajām koksnes izmaiṇām termiskās modifikācijas rezultātā ir tās līdzsvara mitruma pazemināšanās, kas parasti tiek saistīta ar ievērojamu hidroksilgrupu daudzuma samazināšanos koksnē. Tomēr pētījumā, ar acetilēšanas metodi nosakot koksnē pieejamās hidroksilgrupas, tika konstatēts, ka nav lielas atšḳirības starp nemodificētu un termiski modificētu koksni. Šie rezultāti ir l̦āvuši izvirzīt alternatīvu hipotēzi, ka termiski modificētai koksnei raksturīgās pazeminātās ūdens absorbcijas iespējamais cēlonis ir lignīna paaugstinātā šķērssaistīšanās termiskās iedarbības rezultātā (Boonstra and Tjeerdsma, 2006). Termiski modificētas koksnes līdzsvara mitrums, atkarībā no modifikācijas apstākḷiem, var būt līdz pat par 50\% zemāks nekā nemodificētai koksnei (Tjeerdsma et al., 1998; Borrega and Kärenlampi, 2010; Hill et al., 2012; Willems, 2015). Turklāt lielāka atškirība starp nemodificētas un termiski modificētas koksnes līdzsvara mitrumiem ir pie augstāka vides relatīvā mitruma, ko labi ilustrē sorbcijas izotermas. Tajās uzskatāmi redzams, ka pie augstākiem vides mitrumiem pieaug attālums starp termiski modificētas un nemodificētas koksnes izotermām (Chirkova et al., 2007; Hill et al., 2012; Majano-Majano et al., 2012). Turklāt termiski modificētas koksnes sorbcijas pētījumos ir novērots, ka pirmā cikla absorbcijas līkne ir ievērojami zemāka par nākošo ciklu absorbcijas līknēm, bet desorbcijas līknes ir relatīvi nemainīgas (Chirkova et al., 2007; Hill et al., 2012). Tas tiek skaidrots ar zināmu saišu veidošanos starp koksnes struktūrelementiem modifikācijas laikā, kā rezultātā tiek ierobežota ūdens tvaikam pieejamā virsma, bet pirmā sorbcijas cikla beigās piesātināta ūdens tvaika apstākḷos koksnes struktūra relaksējas, pieejamā virsma palielinās, un nākamajos ciklos absorbcijas līkne ir ievērojami augstāka (Chirkova et al., 2007). Līdzīgi novērojumi ir arī par pretuzbriešanas efektivitātes rādītājiem, kas pirmajā briešanas ciklā ir lielāki nekā nākamajos ciklos (Biziks et al., 2015).

Ir novērots, ka, lai arī visumā starp koksnes masas zudumiem un līdzsvara mitruma samazināšanos pastāv korelācija, tomēr, sasniedzot zināmu līmeni, masas zudumiem palielinoties, līdzsvara mitrums būtiski vairs nemainās (Sundqvist, 2002; Welzbacher et al., 2007; Tuong and Li, 2010). Turklāt ir konstatēts, ka atkarībā no koksnes un vides mitruma termiskās modifikācijas laikā, iegūto materiālu ar vienādiem 
masas zudumiem līdzsvara mitrumi var ievērojami atšḳirties (Borrega and Kärenlampi, 2010). Pētījumā ar hidrotermiski modificētu koksni tika iegūti rezultāti, kuri parāda, ka koksnes briešanas īpašību izmainas var būt atkarīgas arī no koksnes mitruma pirms modifikācijas - lielāka pretuzbriešanas efektivitāte tika sasniegta, modificējot sausāku koksni (Rautkari and Hill, 2014). Termiski modificētai koksnei mainās arī šķiedru piesātinājuma punkts, kas samazinās, pieaugot modifikācijas temperatūrai un laikam (Repellin and Guyonnet, 2005).

Samazinātais līdzsvara mitrums pozitīvi ietekmē termiski modificētas koksnes dimensionālās stabilitātes un ar to saistītos pretuzbriešanas efektivitātes rādītājus (Welzbacher et al., 2007; Windeisen et al., 2007; Korkut and Guller, 2008). Pie augstākām temperatūrām modificētas koksnes briešana var samazināties pat par $70 \%$ (Li et al., 2011). Gan modifikācijas temperatūras paaugstināšana, gan procesa paildzināšana paaugstina pretuzbriešanas efektivitāti, tomēr apstrādes laika pagarināšana ļauj to uzlabot līdz zināmai robežai, kad tālāks uzlabojums vairs nenotiek (Welzbacher et al., 2007). Ar koksnes briešanu saistītā formas stabilitāte termiskās modifikācijas rezultātā neuzlabojas, jo saglabājas anizotropija starp briešanu radiālajā un tangenciālajā virzienā (Hill, 2006; Calonego et al., 2012).

Koksne, kura ir hidrofîls materiāls, termiskās modifikācijas rezultātā kḷūst relatīvi hidrofoba (Gérardin et al., 2007; Kocaefe et al., 2008; Andersons et al., 2010). Koksnes virsmas hidrofobitāte, ko nosaka ar kontaktleṇka mērījumiem, mainās jau pie relatīvi zemām modifikācijas temperatūrām $\left(130-160^{\circ} \mathrm{C}\right)$ (Hakkou et al., 2005). Tomēr ir arī pretējs novērojums, ka koksnes kontaktleņkisis, atkarībā no konkrētās koksnes, palielinās tikai pie modifikācijas temperatūras virs $190^{\circ} \mathrm{C}$, bet pie zemākām temperatūrām pat samazinās (Metsä-Kortelainen and Viitanen, 2012). Atškirīgi rezultāti ir arī par koksnes hidrofobitātes un masas zudumu korelāciju termiskās modifikācijas procesā. Ir pētījums, kurā konstatēts, ka koksnes hidrofobitāte termiskās modifikācijas procesā pieaug proporcionāli masas zudumiem (Borrega and Kärenlampi, 2010), kā arī pētîjums, kur nav konstatēta tieša sakarība starp šo lielumu izmaiņām (Hakkou et al., 2005).

Pētījumu rezultāti par koksnes kapilārās ūdens uzsūkšanas spēju izmaiņām termiskās modifikācijas rezultātā nav viennozīmīgi. Ir konstatēta kapilārās uzsūkšanas palielināšanās, kas, līdzịgi kā citas termiski modificētas koksnes īpašības, ir atkarīga no modifikācijas temperatūras un koka sugas (Johansson and Morén, 2006; MetsäKortelainen et al., 2006). Kā iespējamais cēlonis tiek minēta mikroplaisu veidošanās modifikācijas procesā, kuras iekḷaujas koksnes kapilārajā sistēmā, palielinot tās apjomu. Kapilāro ūdens pacelšanos ietekmē materiāla hidrofobitāte. Paaugstinoties modifikācijas temperatūrai, hidrofobitātes izmaiņas ir lielākas, nekā kapilārās sistēmas pieaugums uz mikroplaisu rēḳina, kā rezultātā kapilārā uzsūkšana pie augstākām modifikācijas temperatūrām atkal samazinās (Johansson and Morén, 2006). Ir konstatēta arī pretēja tendence - pēc koksnes termiskās modifikācijas ūdens absorbcija samazinās (MetsäKortelainen et al., 2006). Citā pētījumā novērots, ka kapilārā uzsūkšana palielinās tikai koksnes aksiālajā virzienā, bet tangenciālajā un radiālajā - samazinās (Pfriem, 2011).

Masas pārneses īpašību izmainas koksnei termiskās modifikācijas rezultātā ir pētītas mazāk. Tomēr ir noskaidrots, ka termiskās modifikācijas rezultātā ievērojami samazinās koksnes ūdens tvaika caurlaidības ātrums, kas tiek skaidrots ar hidroksilgrupu daudzuma samazināšanos un līdz ar to mazāku saistītā ūdens apjomu un tā plūsmu. Savukārt gaisa caurlaidība, kas galvenokārt ir saistīta ar koksnes anatomisko struktūru, nemainās (Rousset et al., 2004; Perré, 2011; Sayar and Tarmian, 2012).

Mehānisko īpašību izmaiṇas. Kā viens no termiski modificētas koksnes trūkumiem tiek minēta tās samazinātā mehāniskā stiprība, kas var būt pat par 50\% zemāka nekā nemodificētai koksnei (Ates et al., 2009; Yildiz et al., 2011; Calonego et al., 2012; 
Widman et al., 2012). Tas būtiski ierobežo termiski modificētas koksnes lietošanu slodzi nesošās konstrukcijās. Tādēḷ ir veikti plaši pētījumi par koksnes mehānisko īpašību izmain̄ām termiskās modifikācijas procesā, jo svarīgi ir atrast termiskās modifikācijas apstākḷus, kas, vienlaicīgi ar labu dimensionālo stabilitāti un bionoturību, nodrošinātu pieņemamu mehānisko īpašību samazināšanās apjomu (Widman et al., 2012). Koksnes mehāniskās īpašības nosaka tās ķīmiskā un makro- un mikrostruktūrālā uzbūve (Arnold, 2010a; Burgert and Dunlop, 2011). Tiek uzskatîts, ka celuloze kā škiedrveida komponents pamatā nosaka koksnes spēju izturēt slodzi (maksimālo stiprību), bet hemicelulozes un lignīns veido matricu, kas nodrošina stresa sadalī̌sanu kompozītā (Salmén et al., 2008; Salmén and Bergström, 2009; Arnold, 2010a). Tomēr koksnes šūnu sieniņu ķīmisko komponentu un to mijiedarbības ietekmes uz koksnes stiprības īpašībām nav līdz galam noskaidrotas (Salmén and Burgert, 2009).

Mehānisko īpašību izmaiṇu apjoms lielā mērā ir atkarīgs no termiskās modifikācijas procesa veida, tā specifiskajiem apstākḷiem, koksnes sugas (Arnold, 2010a; Welzbacher et al., 2011; Militz and Altgen, 2014). Mazāks mehāniskās stiprības samazinājums, koksni modificējot pie vienādiem modifikācijas parametriem, ir koksnes paraugiem, kas modificēti slāpekḷa vidē, salīdzinot ar gaisā modificētiem (Kubojima et al., 2000).

Statiskās lieces pārbaudēs parasti termiski modificētai koksnei ir ievērojami samazinājusies pretestîbas spēja liecei, bet elastības moduḷa izmaiņas visbiežāk ir nelielas, un bieži pēc modifikācijas relatīvi maigos modifikācijas apstākḷos koksnes elastības modulis ir palielinājies (Kubojima et al., 2000; Hill, 2006; Borrega and Kärenlampi, 2008b; Heräjärvi, 2009; Molinski et al., 2010; Pfriem et al., 2010). Lieces stiprības samazinājums tiek saistīts ar hemiceluložu degradāciju, bet elastības moduḷa nelielās izmaiņas tiek skaidrotas ar faktu, ka to galvenokārt ietekmē celuloze un lignīns, kas termiskajā modifikācijā tiek izmainīti mazāk (Esteves et al., 2011). Kā iespējamais elastības moduḷa palielināšanās iemesls tiek minēta celulozes kristāliskuma palielināšanās, kas vienlaicīgi varētu arī izskaidrot salīdzinoši lielo termiski modificētas koksnes trauslumu (Arnold, 2010a). Ir konstatēts, ka pie vienādiem masas zudumiem termiski modificētas koksnes pretestības spēju liecei vairāk ietekmē modifikācijas ilgums, nevis modifikācijas temperatūra (Welzbacher et al., 2011).

Termiskā modifikācija koksnes pretestības spēju saspiešanai aksiālā virzienā samazina daudz mazāk, nekā pretestības spēju liecei, un ir pētījumi, kuros novērota šî koksnes raksturlieluma uzlabošanās termiskās modifikācijas rezultātā (Boonstra et al., 2007; Molinski et al., 2010; Widman et al., 2012). Tomēr citos pētījumos konstatēts, ka, pieaugot modifikācijas intensitātei, koksnes pretestība spiedei samazinās un samazinājums var sasniegt pat 60\% (Ates et al., 2009; Calonego et al., 2012).

Rezultāti par koksnes cietības izmain̄ām termiskās modifikācijas rezultātā ir visai atšķirīgi. Kā pārsvarā visas citas termiski modificētas koksnes īpašības, arī tās cietîba ir atkarīga no modifikācijas temperatūras un ilguma - pie zemākām modifikācijas temperatūrām un īsākiem modifikācijas laikiem koksnes cietība palielinās, bet pie augstākām temperatūrām un ilgākiem laikiem - samazinās. Turklāt līdzīga tendence novērota visos trīs (aksiālais, tangenciālais, radiālais) virzienos (Ates et al., 2009). Ievērojams (48\%) cietības pieaugums paralēli škiedru virzienam ir konstatēts "PLATO" procesā modificētai koksnei (Boonstra et al., 2007).

Viena no raksturīgām termiski modificētas koksnes īpašībām ir tās relatīvais trauslums, kas nozīmē, ka tā ir jutīga pret koncentrētu stresu (Kubojima et al., 2000; Rapp et al., 2006; Heräjärvi, 2009; Arnold, 2010a; Welzbacher et al., 2011). Tam iemesls varētu būt daudzo šḳērssaišu veidošanās termiskās modifikācijas laikā (Salmén et al., 2008; Majano-Majano et al., 2012). 
Termiski modificētas koksnes mehāniskās stiprības samazinājums daḷēji varētu būt saistīts ar tās relatīvi zemāko blīvumu. Tomēr, kā to parāda koksnes īpatnējie stiprības rādītāji, kuru aprēḳinos ṇem vērā materiāla blīvumu, blīvuma izmaiṇas modifikācijas laikā nav galvenais koksnes stiprības samazināšanās iemesls (Molinski et al., 2010).

Koksnes mehāniskā stiprība ir būtiski atkarīga no tās mitruma. Termiski modificēta koksne ir salīdzinoši mazāk jutīga pret mitruma izmaiņām, tādēḷ tās mehāniskā stiprība augsta mitruma apstākḷıs vairs tik būtiski neatšḳiras no nemodificētas koksnes attiecīgajiem rādītājiem (Arnold, 2010a).

Vēl viens aspekts ir lielizmēra paraugu mehāniskās īpašības, kas parasti dažādu dabisku defektu dēl ir zemākas. Lielākajā daḷā pētījumu mehāniskās īpašības tiek pārbaudītas mazizmēra paraugiem bez defektiem un ar stingri kontrolētu škiedru virzienu. Pētījumā, izmantojot dažādu dimensiju paraugus, tika salīdzināta termiski modificētas un nemodificētas koksnes mehāniskā stiprība un novēroja, ka termiski modificētas koksnes gadījumā atškirība starp mazizmēra un lielizmēra paraugu mehāniskajām īpašībām ir lielāka nekā nemodificētai koksnei (Boonstra et al., 2007).

Tas viss ierobežo termiski modificētas koksnes izmantošanu strukturāliem elementiem. Turklāt termiski modificētas koksnes gadījumā nezināmu stiprības parametru aprēķiniem nevar lietot korelācijas faktorus, kādus saskaņā ar standartu LVS EN 384 lieto nemodificētai koksnei, izmantojot pamata raksturlielumus - pretestību liecei, blīvumu un elastības moduli (Widman et al., 2012).

Bioloğiskās noturības izmaiṇas. Koksne, it seviški ekspluatācijas laikā āra apstākḷ̆os, ir pakḷauta dažādu mikroorganismu iedarbībai (Stirling et al., 2011), no kuriem visbūtiskākā ietekme uz koksni ir tā saucamajām trupes un krāsojošām sēnēm.

Krāsojošās sēnes ir termins, ko lieto, runājot par pelējuma un zilējuma sēnēm, kas augšanai labvēlīgos apstākḷıs kolonizē koksnes virsmu. Tās pēc taksonomiskā iedalījuma pieder sēṇu valsts asku sēṇu (Ascomycetes) nodalījumam (Hukka and Viitanen, 1999). Tās nenoārda koksnes pamatkomponentus un galvenokārt ietekmē koksnes dekorativitāti. Tomēr, to izdalītie metabolīti ilgstošā periodā sāk degradēt koksnes komponentus, un intensīvs apaugums paaugstina koksnes virsmas mitrumu, kas var būt veicinošs faktors trupes sēṇu attīstībai. Termiskā modifikācija nepasargā koksni no apaugšanas ar krāsojošām sēnēm (Jämsä et al., 2000; Johansson and Jermer, 2010; Fojutowski et al., 2011; Ahmed et al., 2013b).

Trupes sēnes pieder sēṇu valsts bazīdijsēņu (Basidiomycota) nodalījumam, un to darbības rezultātā tiek degradēti koksnes šūnu sieniṇu pamatkomponenti, kas būtiski izmaina gan koksnes fizikālās īpašības, gan mehānisko stiprību. Virknē pētījumu ir novērots, ka termiskā modifikācija būtiski uzlabo koksnes bioizturību pret koksnes trupes sēnēm un uzlabojums ir atkar̄̄gs no modifikācijas intensitātes (Jämsä et al., 2000; Johansson and Jermer, 2010; Fojutowski et al., 2011; Ahmed et al., 2013b). Ir konstatēts, ka pastāv stingra negatīva korelācija starp koksnes masas zudumiem termiskās modifikācijas laikā un modificētas koksnes masas zudumiem bionoturības testos, kad koksne tiek pakḷauta trupes sēṇu iedarbībai (Chaouch et al., 2010; Johansson and Jermer, 2010; Metsä-Kortelainen et al., 2011) Tomēr ir novērots, ka termiski modificēta koksne nav bioizturīga kontaktā ar augsni, tādēl bez papildus aizsardzības nav lietojama šādos apstākḷos (Kamdem et al., 2002; Yildiz et al., 2011).

Tas, ka bionoturība paaugstinās, pieaugot koksnes apstrādes temperatūrai, norāda uz savstarpēju bionoturības un koksnes kīmisko izmaiṇu saistību. Tomēr termiski modificētas koksnes bionoturības uzlabošanās mehānismi nav līdz galam izzināti. Paaugstinātā bionoturība tiek saistîta ar polisaharīdu - svarīga koksnes trupes sēnu barības avota - degradāciju termiskās modifikācijas procesā, kā arī termiski modificētas koksnes šūnu sieniņu pazeminātu līdzsvara mitrumu (Hill, 2006, Windeisen et al., 2007; 
Rowell et al., 2009; Ringman et al., 2014). Cita hipotēze uzlaboto bionoturību skaidro ar modificētajiem koksnes polimēriem, kurus sēṇu enzīmi vairs neatpazīst (Weiland and Guyonnet, 2003; Rowell et al., 2009). Kā viens no iespējamiem bionoturības uzlabošanas faktoriem tiek minēta jaunu molekulu ar fungicīdu īpašībām veidošanās termiskās modifikācijas procesā (Kamdem et al., 2000; Willems et al., 2013). Tomēr pētījumā ar ekstraǵētu un neekstrag̣ētu koksni ir noskaidrots, ka ekstraktvielām, kas rodas termiskās modifikācijas rezultātā, nav negatīva ietekme uz koksnes trupes sēņu augšanu (Hakkou et al., 2006). Cita hipotēze termiski modificētas koksnes bionoturību skaidro ar koksnes komponentu fizikālo stāvokli, proti, fizikālu saišu veidošanos starp koksnes pamatkomponentiem temperatūras ietekmēe, kas izpaužas kā termiski modificētas koksnes paaugstināta stiklošanās temperatūra. Tā rezultātā ir apgrūtināta ūdens difūzija, kas nepieciešama sēṇu attīstībai (Willems, 2015). Ir arī viedoklis, ka termiski modificētas koksnes gadījumā biodegradācijas sākšanās tiek inhibēta un degradācija notiek lēnāk, bet mehānisms ir tāds pat kā nemodificētai koksnei (Ringman et al., 2015).

Koksnes krāsas izmaiṇas. Kāda objekta krāsa ir subjektīva sajūta, kas rodas smadzenēs, kad, aplūkojot objektu, no tā atstarotais elektromagnētisko viḷnu kopums redzamās gaismas diapazonā $(400-700 \mathrm{~nm})$ nonāk uz acs tīklenes, kur to absorbē fotoreceptori un ierosina procesus, kas pa redzes nervu tiek noraidīts uz smadzenēm (Ozola, 2015). No priekšmeta atstarotā starojuma spektrālais sastāvs un krāsas sajūta, kādu tas rada, ir atkarīgs no uz priekšmeta krītošā starojuma spektrālā sastāva un š̄ priekšmeta spējas absorbēt dalı no uz tā krītošā elektromagnētiskā starojuma. Priekšmeta raksturīgo absorbciju nosaka tā ķīmiskais sastāvs. Atomus vai atomu grupas, kas spēj absorbēt fotonus ar redzamajai gaismai raksturīgo vil̨nu garumu, attiecīgi sauc par hromoforiem atomiem vai hromoforajām grupām. Lai izvairītos no lielās subjektivitātes, kāda vienmēr pastāv, ja krāsas novērtē un salīdzina cilvēks, krāsu atškirību un izmaiņu noteikšanai pārsvarā izmanto instrumentālas metodes (Skarvelis and Mousilopoulos, 2014). Parasti pētîjumos par koksnes krāsu tiek izmantots CIELAB krāsu modelis, kurā katra krāsa tiek definēta kā punkts trīsdimensionālā telpā ar atbilstošām koordinātēm, un koordinātes atbilst krāsu parametriem: $L^{*}$ - gaišums, $a$ * un $b^{*}$ - krāsainība uz attiecīgi sarkans-zalšs un dzeltens-zils asīm (Esteves et al., 2008b; Buchelt and Wagenführ, 2012).

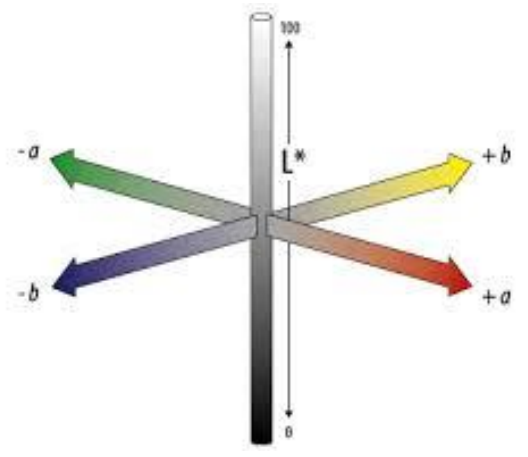

\section{1. att. CIELAB krāsu modeḷa shematisks attēlojums.}

Krāsu parametru izmaiņas tiek aprēķinātas kā starpība starp attiecīgā parametra rezultējošo un sākotnējo vērtỉbu $\left(\Delta \mathrm{L}^{*}, \Delta \mathrm{a}^{*}, \Delta \mathrm{b}^{*}\right)$. Kopējās krāsu izmainas $\Delta \mathrm{Eab}$ ir geometriskais attālums starp sākotnējai un rezultējošai krāsai atbilstošajiem punktiem trīsdimensionālajā krāsu telpā (Tolvaj and Faix, 1995). Minimālās atšķirības, ko spēj uztvert cilvēka acs, ir divas līdz trīs $\Delta$ Eab vienības (Sundqvist and Morén, 2002).

Koksnes krāsa termiskās modifikācijas procesā kḷūst tumša, un daži kokapstrādes uzņēmumi to izmanto, lai vietējo sugu koksnes pēc izskata padarītu līdzīgas tropisko sugu 
koksnēm vai vienkārši palielinātu to dekorativitāti (Tuong and Li, 2010; Miklečić et al., 2011; Akgül and Korkut, 2012; Ferrari et al., 2013a; Militz and Altgen, 2014). Termiskās modifikācijas ceḷā no koksnes, kurai ir krāsas ziṇā izteikti atšḳirīga aplieva un kodolkoksne, var iegūt pēc krāsas relatīvi homogēnu materiālu (Bächle et al., 2007). Ir arī viedoklis, ka tieši tumšā krāsa reizēm nosaka pieprasījumu pēc termiski modificētas koksnes (Schnabel et al., 2007).

Līdzīgi kā citas koksnes īpašības, arī koksnes krāsas izmaiņas būtiski ietekmē termiskās modifikācijas apstākḷi (temperatūra, ilgums, vide) (Schnabel et al., 2007; Yildiz et al., 2011; Ferrari et al., 2012). Vispārējs novērojums ir, ka, paaugstinot modifikācijas temperatūru, koksnes krāsu izmaiņas palielinās (Menezzi et al., 2009; Mehrotra et al., 2010; Majano-Majano et al., 2012). Tomēr ir novērots, ka š̄ palielināšanās notiek līdz zināmai temperatūrai, pēc kuras sasniegšanas turpmāka temperatūras paaugstināšana vairs neizraisa būtiskas krāsu izmaiņas (Ahajji et al., 2009). Koksnes krāsas izmaiņas ir atkarīgas arī no modifikācijas procesa ilguma (Ekstedt, 2002a; Johansson and Morén, 2006; Yildiz et al., 2011; Cademartori et al., 2013). Krāsu izmaiñas palielinās, pieaugot modifikācijas laikam, tomēr straujākas krāsu izmaiņas ir modifikācijas sākumā (Sandak et al., 2015). Ir novērots, ka pirmajās divās modifikācijas stundās notika ap 50\% no visām krāsu izmaiṇām, kādas tika konstatētas pēc 24 stundu modifikācijas (Bekhta and Niemz, 2003). Pētījumu rezultāti, kuros koksnes termiskā modifikācija tika veikta pie dažādām modifikācijas temperatūrām un dažādiem modifikācijas ilgumiem, parādīja, ka pastāv cieša korelācija starp koksnes masas zudumiem (neatkarīgi no modifikācijas temperatūras un ilguma) un koksnes krāsas parametru izmain̄ām (Brischke et al., 2007; Welzbacher et al., 2007). Ietekme uz koksnes krāsas izmaiņām ir arī modifikācijas videi. Modificējot koksni skābekḷa klātbūtnē, tās krāsas izmaiṇas ir ievērojami lielākas, nekā modificējot slāpekḷa vai ūdens tvaika atmosfērā (Esteves et al., 2008b; Chen et al., 2012a; Chen et al., 2012b; Yao et al., 2012). Ir novērots, ka arī procesa vides relatīvais mitrums ietekmē koksnes krāsas izmaiṇas, tomēr modifikācijas temperatūrai un ilgumam ir lielāka ietekme uz šīm izmaiṇām (Bekhta and Niemz, 2003). Tāpat pašas koksnes mitrums ietekmē krāsas izmaiņas - pieaugot koksnes mitrumam, pieaug krāsas izmaiņas (Chen et al., 2012a).

Lielākās izmaiņas termiskajā modifikācijā notiek ar koksnes krāsas gaišuma parametru L* (Tuong and Li, 2010; Lovrić et al., 2014). Ir novērots, ka L* samazinās visos gadījumos, bet krāsainības parametri $a^{*}$ un $b^{*}$ pie zemākām modifikācijas temperatūrām un īsākiem apstrādes laikiem pieaug, taču, paaugstinot temperatūru vai apstrādes ilgumu, samazinās (Ekstedt, 2002a; Bekhta and Niemz, 2003; Brischke et al., 2007; Schnabel et al., 2007; Welzbacher et al., 2007; González-Peña and Hale, 2009a; Cademartori et al., 2013; Mitani and Barboutis, 2013).

Koksnes krāsas izmaiņas termiskās apstrādes laikā ir daudzveidīgu savstarpēji saistītu koksnes ķīmisko komponentu reakciju rezultāts (Matsuo et al., 2012). Tās ir saistītas gan ar koksnes pamatkomponentu, gan ekstraktvielu degradācijas procesiem (Ekstedt, 2002a; Sundqvist and Morén, 2002; Esteves et al., 2008b). Ir izteikta hipotēze, ka pie mazākiem masas zudumiem lielāka ietekme uz krāsas izmaiṇām ir og̣̣hidrātiem un ekstraktvielām, bet pie lielākiem masas zudumiem - lignīnam (González-Peña and Hale, 2009a). Tiek minēti vairāki iespējamie koksnes krāsas veidošanās ķ̄imiskie ceḷi termiskās modifikācijas procesā. Ievērojamas koksnes krāsas izmaiṇas tika konstatētas arī pētījumā, kurā koksne 24 stundas tika apstrādāta $120^{\circ} \mathrm{C}$ temperatūrā, kas ir zemāka par parasti termiskajā modifikācijā lietoto, un pie šādas temperatūras polisaharīdi ir relatīvi stabili. Tādēl ir secināts, ka ievērojams daudzums jaunu hromoforo grupu paaugstinātas temperatūras ietekmē veidojas lignīna oksidācijas un kondensācijas reakciju rezultātā (Chen et al., 2012b). Termiski modificētas koksnes krāsa varētu būt saistīta ar sekundārajiem kondensācijas produktiem un degradācijas produktiem, kas 
veidojas, šḳeḷoties estera saitēm lignīnā un veidojoties difenilmetāna tipa struktūrām, kuras tālāk viegli oksidējas, veidojot krāsainus savienojumus (Funaoka et al., 1990; Chen et al., 2012a; Yao et al., 2012). Termiskās apstrādes laikā lignīna aromātisko hidroksilgrupu oksidācijas rezultātā veidojas hinona vienības saturošas struktūras ar raksturīgu gaismas absorbciju 400 - $500 \mathrm{~nm}$ apgabalā, turklāt intensīvu krāsojumu var dot zemas to koncentrācijas (González-Peña and Hale, 2009a; Yao et al., 2012). Ir novērots, ka arī hemiceluložu hidrolīzē mitruma klātbūtnē veidojas krāsaini degradācijas produkti, bet cita hemiceluložu sastāvdaḷa - glukuronskābe - paaugstinātā temperatūrā $\left(160^{\circ} \mathrm{C}\right)$ pārvēršas tumši brūnā produktā (Beyer et al., 2006; Chen et al., 2012a). Arī pētījumos par celulozes izmaiņām pie paaugstinātas temperatūras ir konstatēts, ka, celulozi karsējot temperatūrā virs $200^{\circ} \mathrm{C}$, tās reducējošajā galā veidojas krāsaini savienojumi (Matsuoka et al., 2011). Celulozes krāsas izmaiņas, veidojoties hromoforiem savienojumiem ar absorbcijas maksimumu pie $450-460 \mathrm{~nm}$, novēroja arī pētījumā, kurā veica celulozes paātrinātu novecināšanu pie $80^{\circ} \mathrm{C}$ (Kolar et al., 2001).

Ṇemot vērā, ka koksnes krāsas noteikšanai tiek izmantotas vienkāršas un nedestruktīvas metodes, ir pētîta iespēja termiski modificētas koksnes krāsu izmantot, lai spriestu par termiski modificētas koksnes mehāniskajām īpašībām. Tomēr iegūtie rezultāti ir pretrunīgi - gan tādi, kas apstiprina ciešas korelācijas pastāvēšanu (Bekhta and Niemz, 2003; González-Peña and Hale, 2009b; Welzbacher et al., 2010), gan arī pretēji (Johansson and Morén, 2006; Niemz et al., 2010).

Salīdzinoši maz ir pētīta termiski modificētas koksnes krāsas homogenitāte. Pētījumos, kuros salīdzināta termiski modificēta dēḷa virsmas un centrālās daḷas krāsa, konstatētas būtiskas krāsu atškirirības, kuras galvenokārt ir saistītas ar gaišuma parametra L* atškirīibām, un novērota tendence, ka atškirības starp modificēta dēḷa virsmu un centrālo daḷu samazinās, pieaugot modifikācijas temperatūrai (Johansson and Morén, 2006; Dubey et al., 2011). Pētîjumos, kuros salīdzināta krāsas variēšana starp dēliem, ir iegūti atšķirīgi rezultāti par to, vai krāsas atšķirības ir lielākas starp nemodificētas, vai starp vienādos apstākḷos termiski modificētas koksnes dēliem (Schnabel et al., 2007; Arnold, 2012).

\subsection{Koksnes novecošanās procesi}

Koksne laika gaitā, lai arī l,oti lēnām, tomēr mainās arī tad, ja tā nav pakḷauta agresīvu vides faktoru (saules starojums, paaugstināts mitrums, temperatūra, dažādi biologiiskie aǵenti, gaisa ķīmiskais un mehāniskais piesārņojums) iedarbībai. Tas ir koksnes novecošanas process, kas galvenokārt tiek saistīts ar ļoti lēniem koksnes autooksidācijas procesiem (Matsuo et al., 2011). Šāda koksnes novecošana ir tik lēna, ka praktiski neietekmē tās lietošanas īpašības. Daudz straujāk koksne mainās dažādu biotisku un abiotisku vides faktoru ietekmes rezultātā. Koksnes izmainas vides faktoru iedarbības rezultātā, kā arī pats vides faktoru iedarbības process uz koksni angliski tiek saukti par "weathering" pretstatā "aging", ar ko tiek apzīmētas koksnes izmainas laika gaitā neatkarīgi no vides iedarbības. Latviešu valodā nav atbilstošu, procesu labi raksturojošu terminu. Latviskais ekvivalents weathering varētu būt "izmaiņa vides faktoru ietekmē”, bet šāda vārdkopa nav ērta biežai pieminēšanai. Tādēl šajā darbā kā "weathering" vides faktoru ietekmē latviskais ekvivalents ir lietots termins "novecošanās", un koksnes pakḷaušana vides faktoru iedarbībai tiek saukta par "novecināšanu". 


\subsubsection{Koksni ietekmējošie vides faktori}

Koksnes novecošanās ir plaši pētīta, jo šî procesa izprašana ir cieši saistīta ar koksnes kvalitātes saglabāšanu lietošanas laikā. Koksnei atrodoties ārtelpā, tā ir pakḷauta kompleksai ķīmisku, biologisku un mehānisku faktoru iedarbībai, kā rezultātā tā pakāpeniski, straujāk vai lēnāk, noārdās (Feist, 1990a; Sandberg and Söderström, 2006; Evans, 2013). Jebkuram materiālam agresīva vide nepārtraukti nejaušās vietās visā materiāla virsmā izraisa l,oti lielu skaitu individuālu molekulu degradāciju, kas lēnām akumulējas, līdz parādās makroskopiskas, saskatāmas izmaiņas (Croll and Hinderliter, 2008). Koksnes novecošanās process un galarezultāts ir atkarīgs no konkrētiem tās ekspluatācijas apstākḷiem (Creemers et al., 2002; Schnabel et al., 2009).

Ir konstatēts, ka galvenie abiotiskie atmosfēras faktori, kas ietekmē koksnes novecošanos, ir solārais starojums, mitrums, skābeklis un temperatūra, un, tiem vienlaicīgi iedarbojoties uz koksni, veidojas sinergisks efekts (Feist, 1990a; Horn et al., 1994; Hon, 2000; Andrady et al., 2003; Temiz et al., 2005). Šie faktori parasti būtiski nemazina koksnes izstrādājumu stiprības īpašības, bet to ietekmē koksne ievērojami mainās vizuāli - mainās koksnes krāsa, veidojas plaisas, virsma erozijas rezultātā kḷūst raupja (Evans, 2013). Tādēḷ novecošanās procesu novēršana vai vismaz palēnināšana ir koksnes dekoratīvo īpašību saglabāšanas pamatnosacījums.

No abiotiskajiem vides faktoriem saules starojums ir atzīts kā primārais koksnes izmaiņu cēlonis tās āra ekspozīcijas laikā (Feist, 1990a; Pandey and Khali, 1998; Evans, 2013). Saules radītā elektromagnētiskā starojuma daļa, kas nonāk līdz zemes virsai, tiek nosacīti iedalīta ultravioletajā (UV), redzamajā (400 - $700 \mathrm{~nm}$ ) un infrasarkanajā (IS) starojumā. Saskan̄ā ar Starptautiskās Apgaismojuma Komisijas (CIE - Commission Internationale de l'Eclairage) datiem uz zemes nonākošā saules starojuma spektrālais sadalījums ir dots 1.1. tabulā.

1.1. tabula

Uz zemes nonākošā saules starojuma spektrālais sadalījums (CIE dokuments No 85)

\begin{tabular}{cccc}
\hline Starojuma veids & $\begin{array}{c}\text { Viḷnu garums, } \\
\text { nm }\end{array}$ & $\begin{array}{c}\text { \% no kopējāa } \\
\text { solārā starojuma }\end{array}$ & $\begin{array}{c}\text { Starojuma } \\
\text { intensitāte, } \mathbf{~ W ~} \mathbf{~ m}^{\mathbf{2}}\end{array}$ \\
\hline UV & $295-400$ & 6.8 & 74.5 \\
\hline Redzamā gaisma & $400-800$ & 55.4 & 678.78 \\
\hline IS & $800-2450$ & 37.8 & 411.62 \\
\hline
\end{tabular}

Starojumu ar vilı̣nu garumu virs $700 \mathrm{~nm}$, kas sastāda ap 42\% no visas zemes virsmu sasniegušās saules starojuma enerğijas, cilvēka acs neuztver. Redzamā gaisma, līdzīgi kā IS starojums, arī var paaugstināt objekta temperatūru, bet būtiskāk ir tas, ka šis starojums organiskajos polimēros var ierosināt fotoḳimiskus procesus. Savukārt UV starojuma izraisītā objekta temperatūras paaugstināšanās ir nenozīmīga, toties tas ḷoti daudzos polimērmateriālos spēj izraisīt fotoḳīmiskas reakcijas (Kockott, 1989). Uz zemes nonākošā UV starojuma daudzums galvenokārt ir atkarīgs no diennakts laika, sezonas, ǵeogrāfiskās lokalizācijas (ǵeogrāfiskā garuma un augstuma), atmosfēras stāvokḷa (mākoņiem) (Diffey, 1991). UV starojuma līmeni ietekmē arī antropogēnie faktori - gaisā esošie aerosoli un cietās dalịnas, kā arī ozona slāṇa biezums (Galichet, 2012). Koksnei saules elektromagnētiskā starojuma UV daḷa ir atzīta par primāro fotoḳīmisko procesu cēloni, kas izraisa plaša spektra ķīmiskās izmaiņas koksnes virskārtā, īpaši skarot lignīnu (Feist, 1990a; Hon, 2000; Budakci, 2006; Heitner, 2010). Tas izskaidrojams ar gaismas 
fotonu enerğijas (E) palielināšanos, samazinoties to viļ̣nu garumam, ko apraksta PlankaEinšteina vienādojums:

$$
E=h \cdot v=h \cdot c / \lambda
$$

kur:

$$
\begin{aligned}
& v \text { - starojuma frekvence; } \\
& \text { c-gaismas àtrums; } \\
& \text { h - Planka konstante; } \\
& \lambda \text { - vilı̧na garums. }
\end{aligned}
$$

Lai tiktu ierosināta fotoķīmiska reakcija, substrātam ir jāabsorbē fotoni, kuru enerğija ir pietiekoša, lai tiktu šḳeltas ķīmiskās saites (Hon, 2000).

Pētījumos par starojuma iespiešanās un tā izraisīto ķīmisko izmaiņu dziḷumu koksnē noskaidrots, ka fotodegradācijas skartais slānis mainās atkarībā no starojuma viḷna garuma, koksnes blīvuma un apstarošanas ilguma, sasniedzot maksimāli $700 \mu \mathrm{m}$ dziḷumu (Kataoka and Kiguchi, 2001; Kataoka et al., 2005; Kataoka et al., 2007; Živković et al., 2014). Tas, ka UV starojums, kas ir būtiskākais koksnes novecošanos izraisošais faktors, rada izmaiṇas tikai plānā koksnes virsējā slānī, nosaka arī to, ka koksnes novecošanās atmosfềras faktoru iedarbības rezultātā ir izteikti virsmas parādība (Feist and Hon, 1984). Ir konstatēts, ka koksnes fotodegradāciju, lai gan mazākā apmērā, izraisa arī garāki viḷni par UV, proti, saules starojuma spektra redzamās daḷas īsākie viḷni - līdz pat 515 nm (Kataoka et al., 2007; Živković et al., 2014). Dziḷums, kādā starojums iekḷūst koksnē, ir atkarīgs no starojuma viḷ,na garuma - jo garāki viḷni, jo dziḷāk koksnē tie iekḷūst. Tādējādi redzamās gaismas violetās daḷas stari iekḷūst un izraisa fotoḳimiskās reakcijas koksnē dziḷāk nekā UV starojums (Kataoka and Kiguchi, 2001). Tas jāṇem vērā, izvēloties pārklājumus koksnei, ko paredzēts lietot āra apstākḷos.

Otrs būtisks koksnes novecošanos ietekmējošs faktors ir mitrums - gaisa relatīvais mitrums un tā maiņas, rasa, nokrišņi. Ūdens pats par sevi neizsauc ievērojamas ḳīmiskas izmaiņas koksnes virsējos slān̨os (Anderson et al., 1991; Owen et al., 1993; Horn et al., 1994; Pandey and Khali, 1998). Tomēr ir konstatēts, ka brīvo radikāḷu veidošanās, kas ir viens no fotodegradācijas būtiskiem soḷiem, ievērojami palielinās, pieaugot koksnes mitrumam (Hon, 2000). Ūdens klātbūtne paātrina arī lignīna fotodegradācijas procesu (Owen et al., 1993; Sudiyani et al., 1999; Turkulin et al., 2004). Tomēr ūdens galvenā loma koksnes novecošanās procesā ir saistīta ar plaisu rašanos koksnes virsmā. Mainoties vides mitrumam, koksnē starp virsējiem un dziḷākiem slāņiem veidojas mitruma gradients, kā rezultātā virsējie slāṇi tiek pakḷauti paaugstinātam stiepes spriegumam, koksne deformējas un atsevišķās vietās šūnas atdalās viena no otras (Feist, 1990a). Plaisu veidošanās raksturs ir atkarīgs gan no koku sugas, gan kokmateriālu (dēlu u.c.) izcelsmes vietas koka stumbrā, jo tas lielā mērā ir saistīts ar koksnes anatomisko struktūru, briešanas īpatnībām (Flæte et al., 2000). Turklāt ūdens, uzbriedinot šūnu sieninas, veicina starojuma iespiešanos apgabalos, kas citādi gaismai nav pieejami (Sudiyani et al., 1999). Pētījumi, kuros kā novecošanās kritērijs tika izmantotas plānu koksnes slokšņu stiepes pretestības izmainas, parādīja, ka paaugstināts vides relatīvais mitrums paātrina koksnes degradāciju un īpaši celulozes degradāciju (Derbyshire and Miller, 1981; Turkulin et al., 2004). Ūdens arī izskalo no koksnes virsmas fotodegradācijas procesā radušos šķīstošos savienojumus, un koksnes virsma kḷūst bagātāka ar celulozi, kas rada novecojušai koksnei raksturīgo, atkarībā no apstākḷiem, gaišāk vai tumšāk pelēko krāsu (Feist, 1990a). Tā kā lignīns, kurš sastāda lielu dalı no koksnes starpšūnu materiāla, saules starojuma iedarbībā daḹji degradējas, virsējās koksnes šūnas vairs nav cieši saistītas ar pārējo koksni, un 
ūdens tās viegli noskalo, kā rezultātā sākas koksnes virsmas erozija un tā kḷūst raupja (Feist and Hon, 1984; Sivrikaya et al., 2011). Ir konstatēts, ka novecošanās laikā degradācijai vairāk pakḷautas koksnes tangenciālās virsmas, jo radiālie serdes stari uz šīm virsmām ḷauj ūdenim dziḷāk ieplūst koksnē un vieglāk izskalot degradācijas produktus (Huang et al., 2012a).

Temperatūra, kāda tā mēdz būt, ekspluatējot koksni āra apstākḷıs, tiešas k̦īmiskas izmaiņas koksnē neizraisa, bet paaugstināta temperatūra var paātrināt fotoḳīmiskās, oksidatīvās un hidrolītiskās reakcijas (Persze and Tolvaj, 2012). Savukārt zema vides temperatūra var kavēt fotodegradācijas procesus. Pētījumā, kurā koksne tika apstarota ar UV starojumu pie $-40^{\circ} \mathrm{C}$, pēc 50 stundu apstarošanas netika konstatētas ne koksnes krāsas, ne parasti novecošanai raksturīgās koksnes kīmiskās izmainas (Mitsui and Tsuchikawa, 2005). Toties koksnē esošā brīvā ūdens sasalšana un atkušana zemā apkārtējās vides temperatūrā var veicināt plaisu veidošanos (Feist, 1990a).

Koksnes novecošanos var ietekmēt arī gaisa piesārn,ojums. Skābie lieti var veicināt polisaharīdu hidrolīzi (Hon, 2000). Ar vēju nestas abrazīvās dalıiņas, kas tieši vai, vispirms nonākot koksnes plaisās, veicina koksnes eroziju, mehāniski atšḳeḷot koksnes šķiedras, starp kurām, galvenokārt starpšūnu slāṇa fotodegradācijas dēḷ, ir vājinājusies savstarpējā saistība (Feist, 1990a).

Koksnes dekorativitāti, ekspluatējot to āra vai paaugstināta vides mitruma apstākḷos, būtiski var ietekmēt arī biotiskie faktori - dažādas pelējuma un krāsojošās sēnes, aḷges, sūnas. Galvenais koksnes dekorativitāti ietekmējošais biotiskais faktors ir krāsojošās sēnes, kas spēj attīstîties arī citu mikroorganismu augšanai visai nelabvēlīgajos apstākḷos, kādiem pakḷauta koksnes virsma āra vidē - biežas mitruma maiṇas, ilgstoši sausuma periodi, augsta solārā radiācija, straujas temperatūru mainas. Šīs sēnes nenoārda koksnes šūnu sieniņas veidojošos polimērus, tādēl būtiski neietekmē koksnes stiprības kvalitāti, bet izmaina koksnes izskatu - tā iegūst netīri pelēku krāsu (Hernandez, 2012).

Koksnes novecošanās ir atkarīga arī no pašas koksnes - koka sugas, blīvuma, ķīmiskā sastāva, agrīnās un vēlīnās koksnes sadalījuma, šķiedru novietojuma attiecībā pret virsmu. Dati par skujkoku un lapkoku salīdzinošu izturību novecošanās procesā ir pretrunīgi - ir pētījumi, kuru rezultāti liecina, ka skujkoki ir izturīgāki pret novecošanos (Pandey et al., 2008a; Pandey et al., 2008b), kā arī gluži pretēji novērojumi, kas l̦auj secināt, ka fotodegradācija ātrāk un lielākā apmērā notiek tieši skujkoku koksnē (Colom et al., 2003; Mitsui and Tsuchikawa, 2005). Ir konstatēts, ka koksnes novecošanās ir atšḳirīga dažādām sugām, ko nosaka gan atšḳirīgais ḳīmiskais sastāvs - galvenokārt atškirības ekstraktvielu un lignīna daudzumā un sastāvā, gan arī koksnes blīvums (Anderson et al., 1991). Novērots, ka pastāv cieša, lai arī ne lineāra, negatīva korelācija starp koksnes blīvumu un fotodegradācijas dziḷumu un ātrumu (Anderson et al., 1991; Kataoka et al., 2005; Kataoka et al., 2007; Metsä-Kortelainen et al., 2011). Mazāka blīvuma dēl agrīnā koksne ir jutīgāka pret fotodegradāciju, nekā vēlīnā. Tādēl arī ievērojami atšķiras agrīnās un vēlīnās koksnes erozijas ātrums, kā rezultātā sugām ar izteikti atšķirīgām agrīnās un vēlīnās koksnes zonām novecošanās procesā veidojas vilı̣aina virsma (Horn et al., 1994; Williams et al., 2001b; Williams et al., 2001c; Kataoka et al., 2005). Savukārt plaisu veidošanos būtiski ietekmē gadskārtu un šķiedru novietojums, kā arī juvenilās koksnes klātbūtne kokmateriālā (Flæte et al., 2000).

Koksnes novecošanās ir atkarīga ne tikai no konkrētajiem klimatiskajiem apstākḷiem un koksnes uzbūves īpatnībām, bet arī no attiecīgā kokmateriāla novietojuma ekspluatācijas laikā. Gada summārais UV starojums uz horizontālas virsmas $\left(0^{\circ}\right)$ ir par $10 \%$ lielāks nekā uz virsmas, kas atrodas $45^{\circ}$ leṇķ̄i, un par 50\% lielāks nekā uz vertikālas $\left(90^{\circ}\right)$ virsmas (Evans, 1989). Savukārt fotodegradācijas produkti labāk izskalojas no slīpām un vertikālām virsmām, bet uz horizontālas virsmas āra apstākḷos vieglāk veidojas 
putekḷu, ziedputekšṇu un citu dalinnu stānis, kas var daḷēji pasargāat virsmu no fotodegradācijas, bet vienlaicīgi ir arī barības bāze krāsojošām sēnēm. Tomēr lielākā nozīme koksnes novecošanās procesā ir krītošā starojuma leṇķim. Erozijas ātrums koksnei, kas atrodas $45^{\circ}$ leṇķ̄î, ir gandrīz divas reizes lielāks nekā $90^{\circ}$ (vertikāli) novietotai koksnei (Evans, 1989; Williams et al., 2001a).

Galvenie koksnes parametri, kas visbiežāk tiek izmantoti pētījumos, lai novērtētu un salīdzinātu koksnes novecošanās procesus, ir koksnes krāsas izmaiņas, virsmas ķīmiskās izmaiņas un koksnes mikro- un makrostruktūras izmaiṇas. Krāsas salīdzināšanai parasti izmanto atstarošanas spektrus un CIELAB krāsu modeli. Plašāk lietotā ķīmisko izmainuu noteikšanas metode ir IS spektroskopija, izmantojot ATR papildierīci, kas ḷauj uzņemt koksnes virsmas absorbcijas spektrus. Koksnes struktūras izmaiņas tiek novērtētas vai nu vizuāli, vai arī pētītas ar dažādu veidu mikroskopiskajām metodēm.

\subsubsection{Koksnes izmaiṇas vides faktoru iedarbības rezultātā}

Krāsas izmaiṇas. Viena no būtiskām, l̦oti ātri pamanāmām novecošanās pazīmēm, koksnes virsmai nonākot saskarē ar saules starojumu, ir krāsas izmaiņas (Tolvaj and Mitsui, 2005; Oltean et al., 2008). Tomēr tās ietekmē ne tikai fotooksidācijas un fotodegradācijas produktu rašanās, bet, ekspluatējot koksni āra apstākḷos, arī to izskalošanās no koksnes virsmas ar lietus ūdeni un virsmas apaugšana ar krāsojošām sēnēm (Ohkoshi, 2002; Schnabel et al., 2009; Hernandez, 2012).

Koksnes krāsa novecošanās procesā mainās, jo starojuma izraisītu kīmisko reakciju rezultātā veidojas hromoforas grupas saturoši savienojumi (Hon, 2000). Ir konstatēts, ka starp fotodegradācijas izraisītajām izmaiṇām koksnes virsmas ķīmiskajā sastāvā un krāsas izmaiņām pastāv cieša korelācija (Pandey, 2005b; Wang and Ren, 2008). Tā kā koksnes krāsas noteikšana ir vienkāršs, ātrs un koksni nedeformējošs process un krāsas izmaiņas ḷauj spriest par galveno fotodegradācijas procesu norisi, tieši koksnes krāsas izmaiṇas bieži izmanto, lai izsekotu, novērtētu un salīdzinātu koksnes novecošanās procesus (Tolvaj and Mitsui, 2005; Oltean et al., 2008; Schnabel et al., 2009).

Koksni apstarojot ar UV starojumu, koksnei raksturīgā redzamās gaismas absorbcija, kas nosaka tās krāsu, izmainās diezgan plašā redzamās gaismas spektra apgabalā, kas norāda uz dažādu hromoforo grupu veidošanos koksnes novecošanās procesā (Pandey et al., 2008a). Novecošanās rezultātā lielākās koksnes atstarošanas spektra izmain,as, proti - absorbcijas palielināšanās, ir tā sauktajā spektra zilajā apgabalā $(400-500 \mathrm{~nm})$, kas atbilst savienojumu ar hinonu struktūru absorbcijas apgabalam (Tolvaj and Faix, 1995; Agarwal, 1999; Yao et al., 2012).

Koksnes krāsas izmaiṇas dažādām koku sugām novecošanās procesā atšķiras, kas tiek saistīts ar atšķirībām to kīimiskajā sastāvā (Kishino and Nakano, 2004; Tolvaj and Mitsui, 2005; Oltean et al., 2008). Tomēr, pakḷaujot koksni apstarošanai gan ar pilnam saules spektram, gan tikai UV dal̦ai atbilstošu starojumu, ir novērojamas kopējas tendences - gaišuma samazināšanās (negatīvas $\Delta \mathrm{L}^{*}$ vērtības) un krāsainības palielināšanās (pozitīvas $\Delta \mathrm{a}^{*}$ un $\Delta \mathrm{b}^{*}$ vērtības) (Pandey, 2005b; Tolvaj and Mitsui, 2005; Deka et al., 2008; Deka and Petrič, 2008; Wang and Ren, 2008).

Lielākās krāsu izmaiņas koksnē ir saistītas ar hromoforajiem savienojumiem, kas rodas lignīna fotodegradācijas procesā, tomēr arī ekstraktvielām ir zināma ietekme uz krāsu izmaiṇu starojuma iedarbības rezultātā (Pandey, 2005a). Pētījumā par celulozes fotodegradāciju pēc apstarošanas ar UV starojumu netika konstatētas būtiskas izmaiņas absorbcijas spektra 380 - 800 nm apgabalā, kas nozīmē, ka izmaiņas, kādas notiek ar 
celulozi koksnes novecošanās procesā, būtiski neietekmē koksnes krāsu (MolnarHamwas et al., 2006).

Solārā starojuma spektra dažādi apgabali izraisa atškiirīgas koksnes krāsas izmainas (Živković et al., 2014). Starojuma viḷnu apgabals, kas atbilst redzamās gaismas spektra zilās daḷas viḷ,nu garumiem $(430$ - $500 \mathrm{~nm})$, it sevišḳi ekspozīcijas sākumposmā, var izraisīt koksnes balēšanu, kas krāsu koordinātēs atspoguḷojas kā gaišuma parametra L* palielināšanās un krāsainības parametru a* un b* samazināšanās (Kataoka et al., 2007; Živković et al., 2014). Pētījumā, kurā koksnes apstarošanai izmantoja dažādu spektra apgabalu šauru joslu starojumu, tika konstatēts, ka starojums līdz $500 \mathrm{~nm}$ izraisa koksnes krāsas izmaiņas, bet ar IS spektroskopiju konstatējama lignīna degradācija notika, tikai iedarbojoties uz koksni starojumam ar viḷnu garumu mazāku par $430 \mathrm{~nm}$ (Kataoka et al., 2007). Ir noskaidrots, ka koksnes krāsu izmaiṇas ātrāk notiek pie zemas intensitātes īsākiem viḷniem nekā pie augstākas intensitātes garākiem viḷniem (Müller et al., 2003).

Apstarojot koksni ar UV starojumu, krāsu izmaiṇas notiek ḷoti strauji un, atkarībā no novecināšanas intensitātes, salīdzinoši ātri sasniedz stāvokli, kad apstarošanas turpināšana vairs būtiskas krāsas izmaiņas neizsauc (Tolvaj anf Faix, 1995; Pandey, 2005b; Oltean et al., 2008; Wang and Ren, 2008; Tolvaj and Mitsui, 2010). Visstraujākās krāsu izmaiņas ir pirmo stundu laikā (Sharratt et al., 2009; Agresti et al., 2013). Toties tās koksnē turpinās vēl kādu laiku pēc apstarošanas pārtraukšanas, kas norāda, ka hromoforie savienojumi veidojas k̦ēdes reakciju rezultātā, kuras turpinās vēl kādu laiku pēc to ierosinātāja - UV starojuma - non,emšanas (Sharratt et al., 2009).

Āra apstākḷos koksnes krāsas izmaiņas ir būtiski atkarīgas no konkrētajiem meteorologiiskajiem apstākḷiem, īpaši sākotnējā posmā, jo, piemēram, no nokrišņiem ir atkarīgs, cik ātri škīstošie, hromoforie fotodegradācijas produkti tiks izskaloti no koksnes virsmas. Vispār koksnei āra apstākḷos ir raksturīga sākotnēji diezgan strauja, vēlāk pakāpeniska visu krāsas parametru $\left(\mathrm{L}^{*}, \mathrm{a}^{*}, \mathrm{~b}^{*}\right)$ samazināšanās, kas rezultātā noved pie tumši pelēkas krāsas, kas, kā tas ir konstatēts mikroskopiskā izpētē, veidojas no gaišu, ar celulozi bagātu šķiedru un melnu pelējuma sēņu hifu kombinācijas (Hernandez, 2012).

Koksnes mikrostruktūras un makrostruktūras izmaiṇas. Novecošanās procesā, pirms koksnes virsmā parādās makroskopiskas izmaiņas, ar mikroskopijas metodēm var konstatēt izmaiņas koksnes šūnu sieniņās. Izmantojot atomspēku mikroskopu, straujas virsmas mikrolīmeņa izmaiņas ir konstatētas jau pēc dažām koksnes novecināšanas stundām saulē (Meincken and Evans, 2009). Pirmās izmainas koksnes šūnu struktūrās novērojamas šūnu sieninu apmaloto poru apmalēs un membrānās - tajās rodas plaisas, kas pakāpeniski palielinās, izplatās un ar laiku blakus esošās poras saplūst, kā rezultātā veidojas jau ar aci skatāmas makroplaisas (Feist, 1990a; Evans et al., 2008). Šūnu apmaloto poru straujā degradācija zināmā mērā varētu būt saistīta ar to kịimisko uzbūvi, jo tajās ir konstatēta augsta lignīna koncentrācija, kas varētu padarīt šos koksnes šūnu apgabalus īpaši jutīgus pret UV starojumu (Fromm et al., 2003). Pēc zināma novecināšanas laika ir novērojama šūnu sekundāro sieniņu delaminēšanās un izmaiņas starpšūnu slān̄̄, kurā ir liela lignīna koncentrācija (Derbyshire and Miller, 1981; Kuo and $\mathrm{Hu}, 1991$; Sandberg, 1999). Pakḷaujot koksni tikai apstarošanai ar UV starojumu bez mitruma main̄ām, izmaiṇas koksnes mikrostruktūrā notiek daudz lēnāk, kas norāda uz mitruma svārstību lielo nozīmi koksnes integritātes saglabāšanā (Owen et al., 1993).

Galvenais virsmas makroskopisko plaisu veidošanos veicinošais faktors ir mitruma maiņas, kuru rezultātā stiepes deformācijas ir lielākas par koksnes elastības robežām (Caba et al., 2007; Flæte et al., 2000). Plaisas koksnes virsmā var veidoties arī tikai ūdens iedarbības rezultātā, bet solārais starojums paātrina un paplašina plaisu veidošanos koksnes virskārtā. Plaisu veidošanās novecošanās procesā ir atkarīga no šķiedru novietojuma koksnes virsmā. Ir novērots, ka uz tangenciālas virsmas veidojas līdz 
pat divas reizes vairāk plaisu nekā uz radiālas virsmas, kas tiek skaidrots ar koksnes anizotropo uzbūvi un galvenajiem ūdens pārvietošanās ceḷiem koksnē, kā rezultātā veidojas atšḳirīgi stresi (Sandberg and Söderström, 2006). Pētījumi āra apstākḷlos, izmantojot filtru aizsegus, parādīja, ka plaisu daudzums un izmēri ir atkarīgi arī no starojuma spektrālā sastāva - starojums ar īsāka garuma viḷniem palielina gan plaisu skaitu uz koksnes virsmas, gan to izmērus (Evans et al., 2008). Plaisas kopā ar koksnes eroziju, kas veidojas, ūdenim izšķīdinot un aizskalojot koksnes fotodegradācijas produktus un nepietiekami stipri ar kopējo koksnes matricu saistītās šķiedras, var veidot jūtamu koksnes virsmas raupjumu (Temiz et al., 2005). To var palielināt arī atšķirīga blīvuma, piemēram, agrīnās un vēlīnās koksnes atrašanās uz virsmas, jo koksnes erozijas ātrums ir lielāks mazāk blīvajā agrīnajā koksnē, un rezultātā var veidoties viḷnaina virsma (Feist and Hon, 1984; Kataoka et al., 2005). Virsmai kḷustot raupjākai, zūd koksnes spīdums, jo, gaismai krītot uz nelīdzenas virsmas, tā vairāk tiek izkliedēta un samazinās tās spoguḷatstarošana (Croll and Hinderliter, 2008).

Kāmiskās izmaiṇas. Koksnes fotodegradācija ir komplekss k̦īmisks process, ko nosaka koksnes kā polimēru kompozīta struktūra. No visiem koksni veidojošajiem pamatkomponentiem tikai lignīns satur hromoforās grupas, kas relatīvi stipri absorbē saules starojuma spektra redzamajā un UV daḷā, tādēl koksnes fotooksidatīvas degradācijas procesa atslēgas posms ir lignīna makromolekulas fotolīze un lignīna fotooksidēšanās (Hon, 2000, George et al., 2005; Heitner, 2010). Lignīnam absorbējot gaismu, veidojas fenoksiradikāli, kas ir konstatēti ar elektronu spinu rezonanses spektroskopiju (ESR) (Hon and Feist, 1992; Chang et al., 2006; Deka and Petrič, 2008). Tie ir ar ilgu dzīveslaiku, un var, savukārt, izraisīt tālāku lignīna degradāciju, hidroperoksīdu, jaunu karbonil- un karboksilgrupu veidošanos, polisaharīdu kēěu šķelšanos un fotooksidāciju (Fisher and Beyer, 2000; Müller et al., 2003; Deka and Petrič, 2008; Heitner, 2010). Lignīna fotooksidācijas rezultātā veidojas jauni redzamo gaismu absorbējoši hromofori orta- un para-hinona savienojumi, kas vizuāli izpaužas kā dzeltēšana (Fisher and Beyer, 2000; Pandey et al., 2008a; Heitner, 2010). N̦emot vērā, ka fotodegradācijas laikā ķīmiskās izmaiṇas notiek tikai plānā koksnes virsmas slānī, visbiežāk ķīmisko izmaiṇu konstatēšanai izmanto IS spektroskopijas metodes (DRIFT un ATR-IR) (Anderson et al., 1991; Colom et al., 2003; Mitsui and Tsuchikawa, 2005; Chang et al., 2006). Novecošanās rezultātā ir konstatētas izmainas vairākos koksnei raksturīgos IS absorbcijas apgabalos, bet lielākās izmaiņas ir saistītas ar IS absorbcijas spektra lignīnam raksturīgajām joslām. Lignīna aromātiskajam gredzenam raksturīgās absorbcijas joslas samazinās un oksidācijas produktiem (karbonil- un karboksilgrupām) atbilstošās pieaug, turklāt tas notiek diezgan strauji jau pašā apstarošanas sākumā (Hon and Chang, 1984; Pandey, 2005b; Pandey et al., 2008a). Lai labāk izprastu koksnes novecošanās ķīmiskos procesus, ir pêtīta no koksnes izdalīta maltās koksnes lignīna (milled wood lignin, MWL) reakcija uz UV apstarošanu. Šis lignīns pēc ķīmiskās struktūras ir vistuvākais lignīnam in situ (Zaḳis, 2008). Iegūtie rezultāti parādīja, ka lignīna apstarošanas rezultātā spektroskopiski konstatētās ķīmiskās izmaiņas ir līdzīgas izmain̄ām, kādas parasti tiek novērotas koksnes novecošanās gadījumā (Hon and Chang, 1984; Chang et al., 2006). Pēc apstarotā lignīna ekstrakcijas ar ūdeni IS spektros tika konstatēta strauja lignīnam atbilstošo spektra joslu intensitātes samazināšanās, kas skaidri parāda, ka UV starojuma izraisītās lignīna fotodegradācijas rezultātā veidojas mazmolekulāri, ūdenī šḳisstoši savienojumi. Pētījumos ar no koksnes izdalītu lignīnu ir konstatēta arī tā vidējās molekulmasas samazināšanās apstarošanas rezultātā (Koch et al., 1994). Pētījumā ar āra apstākḷos novecinātām plānām koksnes sloksnēm (85 - $100 \mu \mathrm{m})$ tika konstatēta ievērojama lignīna satura samazināšanās koksnē jau pēc 35 dienu ekspozīcijas (Evans et al., 1992). Rezultāti par to, vai apstarošanas rezultātā straujāk 
degradējas lapkoku vai skujkoku lignīns, ir pretrunīgi (Pandey et al., 2008b; Wang and Ren, 2008).

Koksnes polisaharīdi - celuloze un hemicelulozes, gandrīz neabsorbē starojuma spektra UV-A (315 - $400 \mathrm{~nm})$ un redzamās gaismas daḷā, tādēl tie ir relatīvi stabili pret solāro starojumu, un fotodegradācijas procesā tiek ietekmēti daudz mazāk (Hon and Chang, 1984; Colom et al., 2003; Molnar-Hamwas et al., 2006; Huang et al., 2012a). Tomēr novecinātas koksnes ūdens ekstraktos ir konstatēti cukuru monomēri, kas liecina par koksnes polisaharīdu degradāciju (Evans et al., 1992). Novērots, ka koksnes novecošanās rezultātā palielinās celulozes satura attiecība pret hemicelulozēm, kas varētu liecināt par daļēju hemiceluložu noārdīšanos, ko varētu veicināt hemiceluložu atbrīvošanās no lignīna-hemiceluložu matricas lignīna degradācijas dēḷ (Evans et al., 1992). Āra novecināšanas rezultātā palielinās koksnes kristāliskums, kas savukārt norāda uz koksnes amorfās daḷas noārdīšanos (Lionetto et al., 2012). Arī celulozes makromolekulas saules starojuma ietekmē šḳeḷas, kā rezultātā mazinās tās polimerizācijas pakāpe un stiprība (Hon, 2000). Tomēr polisaharīdu degradācijas mehānismi koksnes novecošanās procesā līdz galam vēl nav izprasti (Evans, 2013).

Daudzas koksnes ekstraktvielas ir labi solārā starojuma UV un redzamās spektra dalıas absorberi (Pandey and Khali, 1998; Pandey, 2005a). Ekstraktvielas gan pašas nosaka koksnes krāsu, gan koksnes novecošanās laikā piedalās koksnes krāsas izmaiņas procesā, gan UV iedarbības rezultātā degradējas (Pandey and Khali, 1998; Pandey, 2005a; Zahri et al., 2007; Huang et al., 2012a). Tā kā ekstraktvielas nav koksnes šūnu sieniņu uzbūves pamatelementi, tās, absorbējot UV starojumu, var daḷēji pasargāt koksnes pamatkomponentus no fotodegradācijas (Nzokou and Kamdem, 2006; Chang et al., 2010). Koksnes novecošanās procesā tās pamatkomponentu degradācijas rezultātā ievērojami palielinās ekstraǵējamo vielu īpatsvars, un tās pamatā ir lignīna degradācijas produkti (Hon and Chang, 1984; Kuo and Hu, 1991; Evans et al., 1992).

Visu UV starojuma ierosināto ķīmisko procesu rezultātā koksnē ievērojami samazinās lignīna saturs, nedaudz samazinās celulozes un hemiceluložu saturs, un ievērojami pieaug ar ūdeni ekstraǵējamu vielu saturs, kuras lielā mērā sastāv no fenoliskiem lignīna degradācijas komponentiem (Hon, 2000).

\subsubsection{Vides faktoru ietekme uz termiski modificētu koksni}

Ṇemot vērā, ka termiski modificēta koksne ir salīdzinoši jauns materiāls, pētījumi par tās novecošanās procesiem nav tik pilnīgi kā par nemodificētu koksni un bieži ir vairāk ar salīdzinošu raksturu (termiski modificēta koksne/nemodificēta koksne) nevis procesu izzinoši.

Mākslīgās novecināšanas testā ar simulētu saules gaismu un apsmidzināšanu ar ūdeni ir novērots, ka termiskā modifikācija ir uzlabojusi koksnes spēju saglabāt savu strukturālo integritāti un augstākas modifikācijas temperatūras nodrošina labāku koksnes spēju pretoties virsmas struktūras izmain̄ām (Huang et al., 2013). Arī testā tikai ar mākslīgo apstarošanu ir konstatēts, ka termiski modificētas koksnes virsmā lielas plaisas veidojas mazāk (Huang et al., 2012b). Tomēr āra tests ir parādījis, ka nepārklātas koksnes gadījumā no plaisu veidošanās viedokḷa nav būtisku atšḳirību starp nemodificētu un termiski modificētu koksni (Jämsä et al., 2000).

Pētījumos ir konstatēts, ka termiski modificētas koksnes krāsu izmaiņas UV ietekmē atškiriras no nemodificētas koksnes gan pēc apjoma, gan pēc rakstura un var atšķirties paraugiem atkarībā no modifikācijas intensitātes (Huang et al., 2012b; Tolvaj et al., 2014). Termiski modificēta koksne, pretēji nemodificētai, UV starojuma iedarbības 
rezultātā izbalē (negatīvas $\Delta \mathrm{L}^{*}$ vērtības) (Deka et al., 2008; Huang et al., 2012a; Srinivas et al., 2012; Tolvaj et al., 2014). Rezultāti par salīdzinošu termiski modificētas koksnes rezistenci pret krāsu izmain̄ām novecināšanas procesā atšķiras. Ir pētījumi, kuros konstatēts, ka, salīdzinot ar nemodificētu koksni, termiski modificētai koksnei krāsu izmaiņas novecošanās procesā ir mazākas (Deka et al., 2008; Deka and Petrič, 2008; Huang et al., 2012b; Bakali et al., 2014). Kā iespējamais skaidrojums tiek minēts lignīna stabilitātes pieaugums modifikācijas izraisītu kondensācijas reakciju rezultātā (Huang et al., 2012b). Citos pētījumos ir novērots, ka termiski modificētas koksnes krāsu izmaiṇas ir lielākas (Huang et al., 2012a; Huang et al., 2012b; Srinivas and Pandey, 2012). Tas savukārt tiek skaidrots ar termiski modificētas koksnes mazākām antioksidantu īpašībām, kas ir saistīts ar koksnei raksturīgo ekstraktvielu ar antioksidantām īpašībām degradāciju modifikācijas procesa laikā (Huang et al., 2012b). Savukārt pētījumā, kurā tika apstarotas termiski modificētas skujkoku un lapkoku koksnes, novēroja, ka modifikācija ir uzlabojusi pētīto skujkoku rezistenci pret krāsas main̄ām, bet lapkoku gadījumā, gluži pretēji, lielākas krāsu izmaiņas bija termiski modificētajiem paraugiem (Bakali et al., 2014). Āra testā tika konstatêts, ka gan nemodificēta, gan termiski modificēta koksne àtri kḷūst pelēka, tomēr termiskā modifikācija palēnina šo procesu (Nuopponen et al., 2004b; Metsä-Kortelainen et al., 2011; Yildiz et al., 2011). Pārsvarā visos pētījumos, kuros novērtēta modifikācijas intensitātes ietekme uz termiski modificētas koksnes rezistenci pret novecošanos, ir konstatēts, ka intensīvāka termiskā apstrāde nodrošina augstāku izturību pret novecošanos. Tomēr pētījumā, kurā koksne tika modificēta pie dažādām temperatūrām intervālā no 160 līdz $210^{\circ} \mathrm{C}$ un pēc tam mākslīgi novecināta, apstarojot ar saules spektram atbilstošu starojumu, lignīns koksnes virsslānī bija pilnībā degradēts, neatkarīgi no modifikācijas temperatūras (Stingl et al., 2012).

Pētot kīmiskās izmainas koksnes virsmā pēc apstarošanas ar UV starojumu, ir konstatēts, ka arī termiski modificētas koksnes gadījumā UV starojums ievērojami izmaina koksnes ķīmisko sastāvu un apstarošanas rezultātā koksnē pieaug brīvo radikāļu koncentrācija. Izmaiṇas termiski modificētas un nemodificētas koksnes IS spektros ir ar līdzīgām tendencēm līdzīgos spektra apgabalos (Deka and Petrič, 2008). Tomēr citā pētījumā, vienādos apstākḷlos apstarojot nemodificētu un termiski modificētu koksni, lielāks samazinājums lignīna absorbcijai atbilstošos IS spektru apgabalos konstatēts termiski modificētai koksnei, kas norāda uz tās lignīna ātrāku degradāciju (Srinivas and Pandey, 2012). Savukārt, analizējot IS spektru izmainas pēc dažādiem āra novecināšanas etapiem, konstatēts, ka UV starojuma rezultātā radušies produkti no termiski modificētas koksnes izskalojas mazāk nekā no nemodificētas koksnes. Tas tiek skaidrots ar lignīna augstāko škērssaistīšanās pakāpi koksnē pēc termiskās modifikācijas (Nuopponen et al., 2004b).

\subsubsection{Novecināšanas testi}

Koksnes novecošanās procesu pētǐšanai tiek izmantoti āra un kameras testi. Āra testu galvenais trūkums ir dažādu eksperimenta lokalizācijas vietu atškirīgie apstākḷi, kas turklāt mainās dažādos laika periodos - rezultāts ir atkarīgs no tā, kur un kad tests ir veikts, un mainīgo apstākḷu dēḷ pētījumi nav atkārtojami (Kockott, 1989; Evans et al., 1992; Creemers et al., 2002; Schnabel et al., 2009). Lai arī gada vidējie meteorologiskie rādītāji parasti daudz nemainās, var būt lielas svārstības atsevišķos periodos. Svarīgs ir, piemēram, nevis kopējais nokrišņu daudzums, bet nokrišņu periodu ilgums, jo, tā kā ūdens iekḷūšana koksnē ir difūzs process un atkarīgs no laika, cik ilgi koksne atrodas tiešā 
kontaktā ar ūdeni, pie vienāda nokrišņu kopējā apjoma intensīva, īslaicīga lietusgāze mazāk ietekmē koksni nekā mērens, bet ilglaicīgs lietus (Kockott, 1989).

Lai iegūtu atkārtojamus un salīdzināmus rezultātus gan koksnes, gan koksnes pārklājumu novecošanās izpētei, izvērtēšanai un salīdzināšanai plaši lieto mākslīgās novecināšanas testus novecināšanas kamerās. Kameras testi nodrošina ne vien atkārtojamību, bet tajos, variējot testa apstākḷus, var daudz īsākā laika periodā iegūt priekšstatu par iespējamām materiāla izmaiņām dažādu atmosfēras faktoru iedarbības rezultātā (Hui-Ting and Shang-Tzen, 2001; Müller et al., 2003). Koksnes novecošanās procesa pētījumos izmantotie kameras testi savā starpā galvenokārt atšķiras ar izmantoto starojuma avotu, kā arī ar dažādus āra apstākḷus imitējošiem cikliem (dažāda viḷnu garuma starojums, tumsa, temperatūras maiṇas izsaukta kondensācija, apsmidzināšana ar ūdeni), to intensitāti un ilgumu.

Mākslīgās novecināšanas testos ir iespējams pētīt arī kāda atsevišḳa faktora ietekmi uz koksnes novecošanos. Bieži mākslīgā novecināšana tiek izmantota, lai pētìtu tieši starojuma ietekmi uz koksni (Owen et al., 1993; Müller et al., 2003; Kataoka et al., 2005; Chang et al., 2006; Deka and Petrič, 2008; Wang and Ren, 2008). Tādā veidā var relatīvi īsā laika posmā nodrošināt parauga apstarošanu ar augstu starojuma devu (Kataoka et al., 2005; Chang and Chang, 2001; Oltean et al., 2008). Reizēm mākslīgās novecināšanas testos tiek pētīta tieši ūdens iedarbība uz koksni (Owen et al., 1993).

Kameras testos kā starojuma avotu izmanto dažāda tipa lampas. Plaši lietotas ir vairāku tipu fluorescentās lampas, kas nodrošina stabilu starojuma spektru un ir salīdzinoši lētas (Brennan and Fedor, 2007). UVA-351 lampas ar maksimālo starojuma intensitāti pie $353 \mathrm{~nm}$ tiek lietotas, lai imitētu solārā starojuma UV daḷu, kas iet cauri logu stiklam, bet UVA-340 lampas ar maksimālo starojuma intensitāti pie $343 \mathrm{~nm}$ imitē UV starojuma spektru, kāds var nonākt uz materiāla āra apstākḷos (Chang and Chang, 2001; Grekin, 2006). Novecināšanas kamerās izmantotās fluorescentās lampas gan neemitē visam solārajam starojumam atbilstošu spektru, bet izstaro pamatā tikai spektra UV-A $(315-400 \mathrm{~nm})$ reǵionā un pavisam nedaudz UV-B (280-315 nm) daḷā (Tracton, 2007). Tiek izmantotas arī fluorescentās lampas (FS-40, UVB-313) ar stipri uz īsāko UV viḷnu pusi novirzītu starojuma spektru, tādējādi jūtami iesniedzoties UV-B daḷā, kādas reāli uz Zemes nonākošajā solārajā starojumā nemaz nav. Tas ne tikai paātrina fotodegradācijas procesus, bet var izraisīt arī reakcijas, kurām nepieciešama lielāka aktivācijas enerğija, un dabiskos apstākḷos tās vispār nenotiktu. Globālās klimata maiṇas ir grūti prognozējamas, bet tās var ietekmēt zemi sasniedzošo UV starojumu, galvenokārt mainoties ozona slānim (Diffey, 1991). Tam kḷūstot plānākam, arvien vairāk UV-B starojuma varētu nonāk uz zemes, un FS-40, UVB-313, kā arī dzīvsudraba lampas, kas dod starojumu arī UV-B daḷā, varētu tikt lietotas, lai imitētu šo starojumu un pētîtu tā iedarbību uz materiāliem (Tolvaj and Mitsui, 2005).

N̦emot vērā, ka solārā starojuma spektra redzamās daļas īsākie viḷni arī izsauc koksnē zināmus fotodegradācijas procesus, koksnes novecošanās pētījumiem piemērotas ir arī mākslīgās novecināšanas kameras, kurās starojuma avots ir ksenona lokizlādes lampas, kuru izstarotā gaisma, atkarībā no izmantotajiem filtriem, var aptvert visu uz zemes nonākošā UV un redzamās gaismas spektru - 300-800 nm (Derbyshire et al., 1997; Colom et al., 2003; Kataoka et al., 2005; Wang and Ren, 2008). Ar ksenona lampām visprecīzāk var imitēt pilnu solāro starojumu, bet, lampām novecojot, grūti kontrolēt to starojuma spektrālā sadalījuma un intensitātes izmaiņas. Turklāt šīm lampām ir arī salīdzinoši zema starojuma intensitāte tieši 320 - $340 \mathrm{~nm}$ apgabalā (Brennan and Fedor, 2007).

Reizēm tiek lietotas arī dzīvsudraba lampas ar intensīvu starojumu UV apgabalā, bet ir konstatēts, ka vienādas saules un dzīvsudraba lampu starojuma devas $\left(\mathrm{MJ} / \mathrm{m}^{2}\right)$, īpaši 
apstarošanas sākotnējā posmā, izraisa atškirīịgas izmaiņas koksnē (Tolvaj and Mitsui, 2010; Tolvaj et al., 2011). Vēl viens variants ir lāzera kā starojuma avota izmantošana mākslīgās novecināšanas testos. Tas ḷauj konstatēt, kādas izmaiṇas izsauc konkrēts gaismas spektra vilı̧u garums (Papp et al., 2004; Pandey et al., 2008a).

Otrs būtisks parametrs, kas koksnes mākslīgās novecināšanas testos tiek dažādi variēts, ir ūdens. Kameras testos ir iespējams intensificēt sausuma-mitruma ciklu maiṇu, kā arī nodrošināt ātru un vienmērīgu fotodegradācijas produktu izskalošanu, kas ir būtiski, lai varētu modelēt erozijas procesus koksnē (Kockott, 1989; Arnold et al., 1991; Sudiyani et al., 1999).

Arī paaugstināta temperatūra var paātrināt novecošanās procesus, bet svarīgi, lai mākslīgās novecināšanas laikā netiktu izmantota tik augsta, materiāla pielietojuma videi neraksturīga temperatūra, kas pati par sevi izsauc materiāla izmaiņas (Andrady et al., 2003). Koksnes pārklājumu gadījumā temperatūra novecināšanas kamerā nedrīkst pārsniegt pārklājumam raksturīgo stiklošanās temperatūru, jo virs šīs temperatūras pārklājums ir elastīgāks un labāk iztur mehāniskus spriegumus (Aloui F., 2006).

Eksistē dažādi standarti, kas paredzēti, lai izvērtētu un salīdzinātu materiālu piemērotību lietošanai tādos vai citos apstākḷlos, bet nav speciālas standartizētas metodes koksnes bez pārklājuma novecošanās novērtěšanai. Tādēl bieži koksnes mākslīga novecināšana tiek veikta saskaṇā ar koksnes pārklājumu testēšanai izstrādātā standarta EN 927-6 procedūru. Šis standarts tika izstrādāts, lai salīdzinoši īsā laikāa, mākslīgi novecinot, varētu izvērtēt un salīdzināt dažādu pārklājumu spēju pasargāt koksni no būtiskāko abiotisko faktoru (UV starojums, ūdens dažādā formā) ietekmes. Ir konstatēts, ka vismaz alkīdu pārklājumiem novecošanās izmaiņu raksturs dabīgā āra novecināšanā sakrīt ar izmaināam, kādas rodas, veicot novecināšanu saskaṇā ar šajā testā paredzēto procedūru (Podgorski et al., 2003). Tiek lietoti arī citi novecināšanas režīmi (Owen et al., 1993; Pandey and Khali, 1998; Sudiyani et al., 1999; Temiz et al., 2007). Novecināšanas procesā reizēm tiek iekḷauti arī citi faktori - sasaldēšana un atkausēšana, tumsas periodi, pazemināta temperatūra (Flæte et al., 2000; Mitsui and Tsuchikawa, 2005). Pētījumi par mākslīgās novecināšanas iespējamu tuvināšanu dabīgiem apstākḷiem turpinās, bet līdz šim nav atrasti mākslīgās novecināšanas testu apstākḷi un cikli, kas dotu pietiekoši augstu korelāciju ar dabīgo novecošanos (Tolvaj and Mitsui, 2005; Deflorian et al., 2007).

\subsection{Koksnes aizsardzība pret vides faktoru iedarbību}

\subsubsection{Koksnes pārklājumi un to veidi}

Koksnes aizsardzībai pret vides faktoru iedarbību lieto dažāda veida pārklājumus. Saskan̄ā ar Eiropas Savienības Direktīvu 2004/42/CE "Pārklājums" ir jebkāds preparāts, ietverot organiskos šḳīdinātājus vai pārklājumu pareizai lietošanai vajadzīgus organiskos šķīdinātājus saturošus komponentus, ko lieto, lai uz virsmas iegūtu dekoratīvu, aizsargājošu vai citādas iedarbības plēvīti.

Pārklājumiem var būt dekoratīva, aizsargājoša vai kāda specifiska funkcionāla loma (antikorozijas, pretskrāpējumu, ugunsizturības) vai visu šo lomu kombinācija. Pārklājuma veids un tā funkcijas ir atkarīgas no substrāta īpatnībām, kuram tas ir paredzēts. Ideāls pārklājums ir spējīgs pasargāt substrātu no novecošanās ārējās vides faktoru iedarbības rezultātā. Koksnes gadījumā saules starojums un ūdens iedarbība ir galvenie faktori, no kā būtu jāpasargā koksne tās ekspluatācijas laikā. Turklāt pārklājumam jāatrodas līdzsvarā starp ekonomiskumu, draudzīgumu videi un funkcionalitāti. 
Koksnes pārklājumu funkcijas ir definētas standartā LVS EN 927-1:2013:

- dekoratīvo īpašību saglabāšana;

- materiāla aizsardzība pret nolietošanos (eroziju) vides faktoru ietekmes rezultātā;

- dimensionālo izmaiṇu mazināšana main̄̄gā vides mitrumā;

- virsmas aizsardzība pret krāsojošām sēnēm;

- materiāla funkcionālo īpašību saglabāšana.

Lai varētu izpildīt šīs funkcijas, pārklājuma plēvei uz koksnes ir jābūt:

- pietiekoši elastīgai, jo, mainoties vides mitrumam, koksne rūk vai briest, kā rezultātā mainās tās lineārie izmēri, un pārklājumam jāspēj izturēt spriegumus, kādi tajā rodas koksnes izmēru maiņas rezultātā;

- ar zināmu ūdens tvaiku caurlaid̄̄bas spēju, kas, no vienas puses, nodrošina koksnes relatīvu sausumu augsta vides mitruma apstākḷos, un, no otras puses, nodrošina ūdens tvaika, kas rodas, koksnē paaugstinoties temperatūrai, izplūšanu;

- ar labu adhēziju ar substrātu, ko galvenokārt nosaka pārklājumā izmantotā saistviela;

- spējīgai, no vienas puses, pašai pretoties fotodegradācijai, ko var izraisīt saules elektromagnētiskais starojums, un, no otras puses, spējīgai pasargāt koksni no fotodegradācijas.

Pārklājumi, tai skaitā koksnei paredzētie, tiek klasificēti pēc dažādām pazīmēm:

- paredzētās funkcijas (bāzes slānis, starpslānis, virsslānis);

- segtspējas (caurspīdīgi, daḷēji sedzoši, sedzoši);

- saistvielas (alkīda, akrila, ellıas vai pernicas, poliuretāna);

- paredzētā pielietojuma (iekštelpām, āra vidē, gludām vai raupjām virsmām);

- pagatavošanas tehnoloǵijas (uz šḳīdinātāja bāzes, uz ūdens bāzes, UV starojuma ietekmē žūstošie - parasti tiek izmantoti tikai rūpnieciski, jo to lietošana prasa specifiskus apstākḷus un iekārtas);

- izskata (pārklājuma plēves biezums, spīdīgums);

- plēves veidošanas mehānisma (šķīininātāja iztvaikošana, polimerizēšanās).

LVS EN 927-1:2013 standarts paredz pārklājumu klasifikāciju pēc stabilitātes, iedalot visus koksnes pārklājumus 3 kategorijās: stabili, dạ̄ēji stabili, nestabili. Ar stabilitāti tiek saprasta pārklājuma spēja kontrolēt ūdens plūsmu caur pārklātu virsmu, kas nodrošina koksnes izstrādājumu izmēru saglabāšanos noteiktā līmen̄̄.

Pārklājumi parasti ir vairākslāṇu sistēmas, kas sastāv no bāzes un viena vai vairākiem virsslāṇiem. Pēc vidējā plēves biezuma virs materiāla virsmas koksnes pārklājumus iedala piecās kategorijās. Par minimālas plēves jeb bezplēves pārklājumu

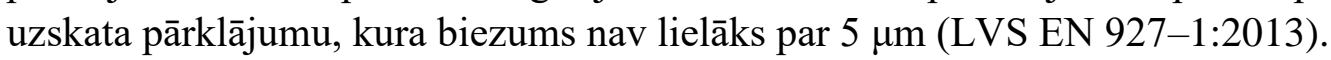

Pārklājumu plēves var būt termoplastisks vai termoreaktīvs materiāls. Termoplastiskas plēves, kas siltuma iedarbībā kḷūst mīkstas un deformējas, rodas, ja to veidošanās pamatā ir tikai šķ̄īinātāja iztvaikošana bez saistvielas ķīmiskām reakcijām. Šajā klasē ietilpst akrila lateksa, vinila (vinilhlorīda, vinilacetāta) un bitumena pārklājumi. Šo pārklājumu plēves ar atbilstošiem šḳidinātājiem var tikt izšķīininātas. Pārklājumi, kuri plēvi veido, iztvaikojot šķīdinātājam un/vai polimerizējoties, ir termoreaktīvi, kas nekḷūst mīksti un nedeformējas paaugstinātās temperatūrās. Šādu pārklājumu plēves veido lielmolekulāri polimēri, kas pēc nožūšanas vairs nav izšḳ̄inināmi (Coating types ..., 1995; Lambourne, 1999b).

Ja jāaizsargā koksne, kas tiek izmantota kā materiāls pats ar savu dekoratīvu vērtību, piemērotākie ir pilnīgi vai daḷēji caurspīdīgi pārklājumi, kas nenosedz koksnes dabīgo izskatu. Tādēl tieši koksnes pārklājumu sektoram ir raksturīgs liels caurspīdīgo pārklājumu īpatsvars (Bulian and Graystor, 2009). 
Pārklājumi pēc sastāva var būt vienkāršas vielas vai kompleksas kompozīcijas, kur katram no komponentiem ir sava specifiska funkcija. Pārklājumu galvenās sastāvdaḷas ir - saistviela un šķ̄indinātājs, kas var būt papildināti ar pigmentiem, piedevām un pildvielām (Lambourne, 1999a; Mathiazhagan and Rani, 2011). Pārklājums var sastāvēt arī tikai no saistvielas, jo tieši tā ir pārklājuma plēvi veidojošais komponents, kas saistās ar substrātu un piesaista arī pārējos pārklājuma komponentus substrātam, ja tādi ir. Saistviela nosaka pārklājuma plēves pamatīpašības, rezistenci pret apkārtējās vides ietekmi un pārklājuma spēju būt efektīvam dotajos apstākḷos. Šḳīdinātājs ir gaistoša komponente, kas nodrošina iespēju saistvielu uzklāt uz substrāta, bet tas vairs neietilpst pārklājuma plēves sastāvā un nenosaka tās īpašības (Bulian and Graystor, 2009). Piedevas ir ķīmikālijas, kuras modificē pārklājuma īpašības pirms vai pēc uzklāšanas. Pildvielas galvenokārt lieto, lai samazinātu pārklājuma cenu, bet tās var arī izmainīt pārklājuma īpašības - palielināt cietību un izmainīt reologiskās īpašības (Jeffs and Jones, 1999; Nikolic et al., 2015).

Svarīgākās koksnes pārklājumos lietotās saistvielas ir apkopotas 1.2. tabulā.

1.2. tabula

Svarīgākās koksnes pārklājumos izmantotās saistvielas (Bulian and Graystor, 2009)

\begin{tabular}{ll}
\hline Dabīgas izcelsmes & Sintētiskas \\
\hline Žūstošās eḷıas & Alkīda svek̦i \\
Pernicas & Poliuretāni \\
Dabīgie svek̦i & Poliesteri \\
Celulozes atvasinājumi & Akrila sveķi \\
& Vinila sveķi \\
& Epoksīda sveḳi \\
\hline
\end{tabular}

Āra lietošanai paredzētajos koksnes pārklājumos kā saistvielu visbiežāk lieto alkīda sveķus, akrila sveķus un žūstošās eḷlas (Coating types..., 1995).

Tā sauktās žūstošās eḷlas pārklājumos izmanto gan kā atsevišķu saistvielu, gan kā alkīdu sveḳu sastāvdaḷu. Žūstošās eḷlas, gaisa skābekḷa klātbūtnē oksidējoties, veido cietu plēvi. Tās ir eḷlas, kuras satur nepiesātinātās taukskābes ar relatīvi lielu dubultsaišu skaitu. Eḷlas žūstošās un nežūstošās iedala atkarībā no to joda skaitḷa, kas izsaka joda daudzumu gramos, kas zināmos apstākḷlos reaǵē ar 100 gramiem nepiesātinātās taukskābes, un tas ir atkarīgs no dubultsaišu īpatsvara taukskābē. Par žūstošām eḷı̄m uzskata eḷlas, kuru joda skaitlis ir lielāks par 130, par dal̦ēji žūstošām - kurām joda skaitlis ir robežās no 90 līdz 130 un nežūstošām - kurām joda skaitlis ir mazāks par 90 (Güner et al., 2006). Žūstošās

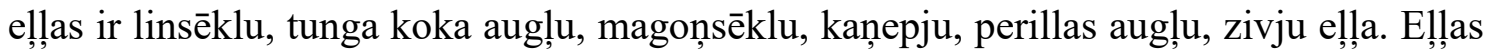
žūšanas ātrums ir atkarīgs, gan no dubultsaišu skaita, gan to novietojuma. Lielāks dubultsaišu skaits un vairāk konjugētas dubultsaites nodrošina ātrāku eḷıas žūšanu. Eḷıas pārklājumos biežāk izmanto dạ̣ēji polimerizētas eḷ,as jeb pernicas (Güner et al., 2006). Salīdzinot ar nemodificētām elı̣ām, pernicas ātrāk žūst, to plēves ir cietākas, ūdensizturīgākas un mazāk dzeltē, bet tām ir sliktākas materiāla slapināšanas un iesūkšanās īpašības (Coating types..., 1995).

Alkīda sveḳi, kurus izmanto koksnes pārklājumu pagatavošanai, parasti ir ar elııu vai taukskābēm modificēti mazmolekulāri poliesteri. Tos iegūst daudzvērtīgo spirtu, divvērtīgo karbonskābju vai to anhidrīdu un nepiesātināto taukskābju vai eḷıu 
polikondensācijas reakcijā pie paaugstinātas temperatūras (Haveren et al., 2007; Bulian and Graystor, 2009). Pirmie alkīda sveķi tika sintezēti XX gs. divdesmitajos gados, jau trīsdesmitajos gados sākās to komerciālā ražošana, un tie strauji iekaroja krāsu un laku rūpniecību, kḷūstot par visplašāk lietoto pārklājumu saistvielu (Hofland, 2012). Poliestera daḷa nodrošina alkīda sveķu cietību, bet taukskābju daḷa vairāk ietekmē to adhēziju un elastību (Miranda, 1993).

Alkīda sveḳu uzbūvi shematiski var attēlot:

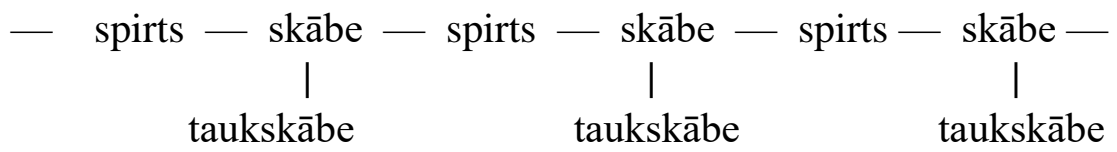

Alkīda sveķi ir relatīvi lēti, viegli lietojami, tiem ir laba adhēzija arī ar ne ḷoti labi sagatavotām virsmām (Coating types..., 1995). Koksnes pārklājumos tradicionāli izmantotie alkīda sveķi ir ar augstu viskozitāti, bet, būdami samērā nepolāras vielas, tie labi šķīst nepolāros šḳīdinātājos tādos kā alifātisko, ciklisko vai aromātisko oglūūeņražu maisījums (Bulian and Graystor, 2009). Alkīda sveki, lai piedotu tiem kādas specifiskas īpašības, var tikt modificēti ar cita veida sveķiem (Athawale and Nimbalkar, 2011; Hofland, 2012). Lai, piemēram, paaugstinātu ūdens un ķ1̄misko izturību, alkīda sveķus modificē ar fenola vai epoksīda svekiem (Miranda, 1993; Bulian and Graystor, 2009).

Alkīda sveķu īpašības lielā mēra nosaka to sintēzē izmantoto ellıu vai taukskābju īpašības un daudzums. Eḷıas daudzums būtiski ietekmē alkīda sveḳu elastību, krāsu, mitrumizturību un žūšanas ātrumu. Tomēr ir konstatēts, ka arī alkīda sintēzei izmantotais karbonskābes anhidrīda veids ietekmē pārklājuma žūšanas ātrumu (Güner et al., 2006).

Alkīdus, atkarībā no ellıas īpatsvara polimērā, iedala (Bulian and Graystor, 2009):

- treknie alkīda sveki (long oil alkyd resins) - ellıas saturs $>60 \%$;

- vidēji treknie alkīda sveḳi (medium oil alkyd resins) - eḷ̦as saturs 40-60\%;

- liesie alkīda sveķi (short oil alkyd resins) - elllas saturs < 40\%.

Šis iedalījums gan nav standartizēts un var variēt dažādos literatūras avotos. Pievienotais eḷıas daudzums nosaka vidējo attālumu starp šḳērssaistīšanās vietām polimerizācijas reakcijās un tādējādi pārklājuma cietību un caurlaidību. Liesie alkīdi labi žūst un ir cieti, bet veido relatīvi neelastīgu plēvi. Savukārt treknie alkīdi žūst lēnāk, bet pārklājuma plēve ir elastīgāka (Miranda, 1993).

Pēdējā laikā, saistībā ar pieaugošo tendenci samazināt naftas izcelsmes produktu izmantošanu, arvien aktuālāki kḷūst pārklājumi uz ūdens bāzes. Pagājušā gadsimta septingdesmitajos gados tika iegūti ūdenī šḳisstoši alkīda sveḳi, bet pārklājumi, kuros tie tiek izmantoti kā saistviela, ir lēni žūstoši, viegli dzeltējoši, ar vāju uzglabāšanas stabilitāti, tādēḷ nav ieguvuši plašu popularitāti (Hofland, 2012). Komerciāli veiksmīgāki ir pārklājumi, kuri tiek pagatavoti kā alkīda sveḳu ūdens emulsijas, izmantojot virsmas aktīvas vielas. Ja alkīda sveķi tiek lietoti pārklājumos uz šḳīdinātāja bāzes, tie ir īsti šḳīdumi, bet pārklājumos uz ūdens bāzes - emulsijas, kurās saistviela atrodas relatīvi lielu agregātu formā, nevis kā atsevišķas molekulas, kā tas ir īstu šķ̄īumu gadījumā. Trešā plašākā alkīda sveķu pārklājumu klase ir, tā saucamie, augsta sausnes satura alkīdi (high solids alkyds), kuros tiek izmantoti alkīda sveķi ar relatīvi zemu viskozitāti, tādēl to atšķaidīšanai līdz lietošanai piemērotam viskozitātes līmenim pietiek ar salīdzinoši nelielu šḳīdinātāja daudzumu. 
Šo trīs plašāk lietoto alkīda sveķu pārklājumu veidu aizṇemtā tirgus daḷa pēdējos gados ir strauji mainījusies, kā tas redzams 1.3. tabulā.

1.3. tabula

\section{Alkīda sveḳu izlietojums (1000 tonnas tīru sveḳu) dažādu veidu pārklājumiem Eiropā (Hofland, 2012)}

\begin{tabular}{lcc}
\hline \multicolumn{1}{c}{ Pārklājuma veids } & 2007. gads & 2013. gads \\
\hline Augsta sausnes satura alkīdi & 10 & 100 \\
\hline Alkīdi uz šksīdinātāja bāzes & 340 & 105 \\
\hline Alkīdi uz ūdens bāzes & 25 & 100 \\
\hline
\end{tabular}

Līdz šim alkīda sveḳos no atjaunojamiem resursiem iegūtas sastāvdaḷas parasti sastāda 60 - 70 \%. Tādēḷ tiek veikti pētījumi, lai arī pašus alkīda sveķus varētu pilnībā iegūt no atjaunojamiem resursiem, izmantojot, piemēram, og̣̣hidrātus (saharozi, inulīnu). Šādu sveķu atšķaidīšanai varētu izmantot tā saucamos reaktīvos šķīinātājus, kas kopolimerizējas ar svek̦iem un neiztvaiko (Haveren et al., 2007). Vēl viens virziens, kurā notiek intensīvi pētījumi, ir tā saucamie hibrīdie sveḳi, kuros ir apvienoti alkīda un akrila vai uretāna sveḳi, kā arī "tribrid” sveķi, kuros ir apvienoti visi trīs - alkīda, akrila un uretāna svek̦i (Nabuur et al., 1996; Athawale and Nimbalkar, 2011; Hofland, 2012).

Akrila svekii ir akrilskābes un metakrilskābes esteri, un tos pamatā izmanto pārklājumos uz ūdens bāzes kā ūdens emulsijas (Ekstedt, 2002b). Akrila pārklājumu cietību un elastîbu nosaka to izgatavošanai izmantotie monomēri. Metilmetakrilāta monomērs veido cietāku plēvi, salīdzinot ar akrilāta monomēru, bet pārklājumi uz akrila bāzes ir salīdzinoši rezistentāki pret ultravioletā starojuma izraisītu degradāciju (Bentley, 1999). Akrila sveķu ražošana ir energoietilpīgs process, un tam nepieciešams gandrīz divreiz vairāk enerǵijas nekā alkīda sveķu gadījumā (Hofland, 2012).

Šobrīd pārklājumu rūpniecībā būtiskas izmaiṇas notiek ne tikai ar pārklājumos izmantotajām saistvielām, bet arī ar lietotajiem šķīdinātājiem. L̄îdz šim tradicionāli vairāk ir lietoti koksnes pārklājumi uz organisko šḳīdinātāju bāzes. Šobrīd šī tendence mainās, un pieaug uz ūdens bāzes veidoto pārklājumu īpatsvars (Bulian and Graystor, 2009; Athawale and Nimbalkar, 2011; Hofland, 2012). Šo tendenci atbalsta arī ar Eiropas Direktīvu 2004/42/EC, kura nosaka piel̦aujamo gaistošo organisko savienojumu (GOS) saturu dažāda veida pārklājumos.

Eiropas direktīva 1999/13/CE kā GOS definē organisku savienojumu, kuram pie $20^{\circ} \mathrm{C}$ veidojas tvaiks. Savukārt Eiropas direktīva 2004/42/CE nosaka, ka GOS ir jebkāds organisks savienojums, kura viršanas sākuma temperatūra ir zemāka vai vienāda ar $250^{\circ} \mathrm{C}$, ko mēra $101,3 \mathrm{kPa}$ standartspiedienā. Šajā pašā direktīvā kā organisks šķīdinātājs tiek definēts jebkāds GOS, ko lieto vienu vai kopā ar citām aktīvajām vielām izejvielu, produktu vai atkritumvielu šķīinināšanai vai atšķaidīšanai, kā tīrīšanas līdzekli piemaisījumu izšḳ̂̄dināšanai, kā disperǵêtājvielu, kā viskozitātes vai virsmas spraiguma regulētāju, kā plastifikatoru vai kā konservantu.

Pārklājumu gadījumā par šḳ̄ininātāju uzskata jebkuru iztvaikojošu šķidrumu, kas ir iekḷauts pārklājuma maisījumā, neatkarīgi vai tas ar citiem pārklājuma komponentiem veido īstu vai koloidālu šḳīdumu. Šḳīdinātāja galvenā loma ir nodrošināt viskozitāti, kāda nepieciešama pārklājuma labai uzklāšanai (Lambourne, 1999b). 
Koksnes pārklājumos kā šḳīinātāju pamatā lieto ūdeni vai organiskos šķīdinātājus, kas parasti ir ogḷūdeņražu maisījumi. Dabīgs, no atjaunojamiem resursiem iegūstams organiskais šķ̄idinātājs ir terpentīns, ko iegūst no kokiem, bet tas ir relatīvi dārgs un ar lēnu iztvaikošanas àtrumu (Coating types..., 1995). No naftas iegūtie organiskie šḳ̄ininātāji var sastāvēt no alifătiskajiem, cikliskajiem vai aromātiskajiem og̣̦ūdeņražiem vai to maisījuma (Lambourne, 1999b).

Pārklājumi uz ūdens bāzes, salīdzinot ar pārklājumiem uz šķ̄īinātāja bāzes, ir komplicētāki pēc savas uzbūves, jo izmantotie sveķi parasti ir ūden̄̄ nešķīstoši. Koksnes pārklājumi uz ūdens bāzes parasti ir termoplastisku polimēru (visbiežāk akrila sveķu) vai mazmolekulāru sveķu (alkīdu vai poliuretānu) emulsijas (Ekstedt, 2002a). Alkīda vai akrila sveķu saistvielas saturošu pārklājumu uz ūdens bāzes pagatavošana ir salīdzinoši komplicēts un arī energoietilpīgs process, jo viendabīgas masas iegūšana prasa komponentu īpašu samais̄̄šanu. Lai nodrošinātu šādu pārklājumu emulsiju stabilitāti, tām nepieciešams pievienot dažādas funkcionālas piedevas. Obligāta piedeva ir virsmas aktīvas vielas, kuras lieto, lai izveidotu emulsiju, nodrošinātu ilglaicīgu tās stabilitāti un mazinātu putošanos. Virsmas aktīivo vielu daudzums parasti svārstās no $0.5 \mathrm{lī} d z 5 \%$ pēc svara attiecībā pret pārklājumā izmantoto sveķu daudzumu. Vēl pārklājumos uz ūdens bāzes bieži tiek lietotas vielas, kas nodrošina pārklājumam nepieciešamās reologiskās īpašības. Tas viss padara šos pārklājumus komplicētus pēc sastāva un videi vairs ne tik draudzīgus. Turklāt pēc pārklājuma plēves izveidošanās daḷa no virsmas aktīvajām vielā paliek nesaistītas un ar lietus ūdeņiem viegli izskalojas ekspozīcijas laikā āra apstākḷlos, tā piesārņojot vidi. Ir arī konstatēts, ka virsmas aktīvās vielas var izmainīt koksnes ūdens sorbcijas raksturu uz koksne - pārklājums robežvirsmas (Ekstedt, 2002a). Pārklājuma kompozīcijā ietilpstošās virsmas aktīvās vielas padara pašu pārklājumu hidrofîlāku, kas nozīmē mazāku ūdens atgrūšanu un lielāku ūdens iespiešanās iespējamību koksnē.

Atkarībā no pārklājumā izmantotās saistvielas un šḳīinātāja, mainās pārklājuma žǔšanas un plēves veidošanās mehānismi. Žūstošo eḷıu plēves veidošanās mehānisma pamatā ir autooksidācijas reakcijas ar gaisa skābekli. Tas ir komplicēts ḳimisko reakciju kopums, kas ietver virkni brīvo radikāḷu veidošanās un rekombinācijas reakciju, kā rezultātā starp taukskābju molekulām veidojas škēerssaites un elı,las viskozitāte paaugstinās līdz līmenim, kad tā pēc taustes kḷūst sausa. Tomēr, lai arī, piemēram, linsēklu ellıa pēc taustes kḷūst sausa dažu dienu laikā, oksidācijas reakcijas turpinās gadiem ilgi un, pieaugot šķērssaistīšanās pakāpei, eḷıas plēve kḷ̂ust arvien cietāka un neelastīgāka. Vienlaicīgi UV ietekmē notiek mazmolekuāru fragmentu atšķelšanās, kas var tikt izskaloti (Lazzari and Chiantore, 1999).

Plēves veidošanās process pārklājumiem, kuros saistviela ir izšḳīināta šķīinātājā (kā tas ir gadījumā, ja saistviela ir alkīda sveķi un šķīdinātājs - organiskais šķ̄idinātājs), ir salīdzinoši vienkāršs, un pārklājuma plēve veidojas fizikālu un ķīmisku procesu rezultātā. Pirmajā fāzē iztvaiko šķ̄īinātājs, kā rezultātā sveķu molekulas nonāk tiešā kontaktā cita ar citu un seko oksidatīva polimerizācija, sveķiem reaǵējot ar atmosfēras skābekli (Ekstedt, 2002b). Principā, alkīdu polimerizācijas process ir tāds pats, kā žūstošo ellıu gadījumā, jo tieši alkīdu taukskābju daḷa iesaistās šķērssaistīšanās reakcijās, veidojot trīsdimensionālu polimēra režği. Žūšanas mehānisma pamatā esošais oksidatīvais process nosaka to, ka alkīda pārklājumus vienā kārtā nevar klāt pārāk biezi, jo kvalitatīvas pārklājuma plēves izveidošanai nepieciešams nodrošināt vienmērīgu šḳīdinātāja iztvaikošanu un vieglu skābekḷa piekḷuvi visā pārklājuma biezumā. Tādēl, ja nepieciešams biezāks pārklājums, jāklāj vairākas kārtas. Alkīdu oksidēšanās procesi 
turpinās arī pēc krāsas nožūšanas, un ar laiku tie kḷūst par pārklājuma novecošanas procesiem, kuru rezultātā pārklājuma plēve pakāpeniski kḷūst arvien trauslāka, var mazināties adhēzija, sākties lobīšanās.

Plēves veidošanās mehānisms akrila pārklājumiem uz ūdens bāzes ir daudz sarežğìtāks, jo saistviela atrodas lielu agregātu veidā, kas, ūdenim iztvaikojot, apvienojas. Bet, lai veidotos stabila plēve, nepieciešama polimēru savstarpēja difūzija starp agregātiem, ko savukārt ietekmē virsmas spraiguma un kapilārie spēki, kas darbojas uz disperğētajām daḷiņām (Ekstedt, 2002b).

\subsubsection{Koksnes pārklājumu modifikācija ar funkcionālām piedevām}

Bez saistvielas un šķīinātāja pārklājumi var saturēt pigmentus un dažādas funkcionālas piedevas. Pigmenti pārklājumu kontekstā ir vielas, kas pārklājuma kompozīcijai tiek pievienotas, lai nodrošinātu pārklājuma segtspēju jeb necaurspīdīgumu un krāsu (Abel, 1999). Pārsvarā tās ir neorganiskas, pārklājuma šḳīinātājā nešḳistošas vielas, kuras pārklājumam tiek pievienotas lielāku vai mazāku cietu daḷinu veidā. Pirms nanomateriālu parādīšanās, jebkādu pigmentu iekḷaušana pārklājumu kompozīcijā mazināja pārklājuma plēves caurspīdību jeb palielināja tās segtspēju. Nelielais daḷinu izmērs, kas ir mazāks par redzamās gaismas viļ̧nu garumu, nosaka to, ka tās neizkliedē gaismu un pārklājums ir caurspīdīgs (Nikolic et al., 2015). Nanodalịn̄ām, pateicoties to lielajai īpatnējai virsmai, ir jaunas īpašības, tādēl pieaug to lietojums arī pārklājumu industrijā (Filpo et al., 2013). Pārklājumos vieni no biežāk lietotajiem nanomateriāliem ir, tā saucamie, caurspīdīgie metālu oksīdi, kuri ir nanoizmēra daliṇu veidā, kas nodrošina pārklājuma caurspīdīguma saglabāšanos. Organiskos pigmentus, lai arī tie nodrošina košāku krāsu, parasti koksnes pārklājumiem, it īpaši tiem, kas paredzēti lietošanai āra apstākḷos, neizmanto, jo tie ir mazāk gaismas izturīgi un ievērojami dārgāki.

Par piedevu pārklājumu gadījumā sauc jebkuru vielu, kas pārklājumam pievienota nelielā daudzumā (parasti < 1\%), lai modificētu pārklājuma īpašības pirms uzklāšanas, uzklāšanas laikā vai pēc plēves izveidošanās (Bulian and Graystor, 2009). Viena no šodienas aktualitātēm pārklājumu jomā ir multifunkcionālas piedevas, kuras vienā produktā apvieno vairākas funkcijas (Athawale and Nimbalkar, 2011). Reizēm viens un tas pats produkts var pārklājumā funkcionēt gan kā pigments, gan funkcionāla piedeva. Tādi ir daudzi neorganiskie pigmenti, kuri vienlaikus darbojas kā UV absorberi.

Piedeva, kas tiek lietota, lai nodrošinātu pārklājuma stabilitāti pirms uzklāšanas, ir pretplēves aǵents, kas aizkavē plēves izveidošanos škiidrā pārklājuma uzglabāšanas laikā. Biežāk lietotie ir oksīmu grupu (>C=NOH) saturoši savienojumi, kuri, veidojot kompleksus ar žūšanas katalizatoriem, inhibē tos, neḷaujot katalizēt pārklājuma oksidēšanās reakcijas ar pārklājuma iepakojumā esošo skābekli, līdz brīdim, kad pēc pārklājuma uzklāšanas paši iztvaiko, tādā veidā atbrīvojot žūšanas katalizatorus, kas var savukārt sākt katalizēt pārklājuma oksidēšanos (Bieleman et al., 2000).

Visas koksnes pārklājumos biežāk lietotās saistvielas ir ar relatīvi lēnu žǔšanas ātrumu, tādēl žūšanas veicināšanai pārklājumos lieto žūšanas katalizatorus jeb sikatīvus. Šìs piedevas lielā mērā nosaka pārklājuma žūšanas procesa ātrumu un vienmērību. Ir divu veidu žǔšanas katalizatori - virsmas un tilpuma. Tilpuma žūšanas katalizatorus lieto biezu pārklājuma plēvju gadījumā, lai žūšana notiktu vienmērīgi (Jeffs and Jones, 1999). Biežāk lietotie virsmas žūšanas katalizatori ir pārejas metālu (kobalta, mangāna, vanādija, 
cērija, dzelzs) organiskie sāļi. Tie ir tā saucamie primārie žūšanas katalizatori. Visbiežāk kā primāros žūšanas katalizatorus lieto tieši kobalta sāḷus, kas, iespējams, ir kancerogēni. Tādēḷ tiek meklēti jauni, efektīvi kobalta žūšanas katalizatoru aizvietotāji (Micciché et al., 2005; Haveren et al., 2007; Kalenda and Mene, 2009). Sekundārie žūšanas katalizatori paši par sevi neveicina pārklājuma nožūšanas procesu, bet, lietoti kopā ar primārajiem žūšanas katalizatoriem, paaugstina to efektivitāti. Populārākie sekundārie žūšanas katalizatori ir cirkonija, kalcija, bārija, cinka un kālija sāḷi.

Būtiskākais pārklājuma plēvi ietekmējošo piedevu uzdevums ir mazināt ultravioletā starojuma (UV) ietekmi un pasargāt virsmu no bioloǵiskās apaugšanas. Globālā radiācija ir viens no visbūtiskākajiem stresu izraisošajiem faktoriem koksnes pārklājumiem āra ekspozīcijas laikā (Creemers et al., 2002). Pārklājuma saistviela, būdama polimērs, ir pakḷauta degradācijas riskam apstākḷos, kad to skar UV starojums (Williams et al., 2000; Saha et al., 2011c). Pētījumos par linsēklu elıllas novecošanos ir novērots, ka UV starojums ievērojami paātrina šo procesu, kas nozīmēe, ka līdzīgi procesi notiek arī linsēklu elılu saturošos produktos (Lazzari and Chiantore, 1999). Pārklājuma degradācijas rezultātā samazinās pārklājuma slāņa biezums, ko pat ir ieteikts izmantot kā pārklājuma novecošanās pakāpes indikatoru (Saha et al., 2011b; Grüll et al., 2014). Turklāt, ja pārklājuma plēve nav pietiekoši bieza, saules starojums var izraisīt arī fotodegradācijas reakcijas koksnes substrātā zem pārklājuma plēves. Lai mazinātu starojuma izraisītu degradāciju, tiek izmantotas vielas ar vairāku veidu darbības mehānismiem (Bieleman et al., 2000; Blanchard and Blanchet, 2011):

- slāpētāji (quenchers) - deaktivizē molekulu ierosināto stāvokli, pārveidojot tās atpakal, neierosinātā stāvoklī;

- UV absorberi - absorbē UV starojumu un pārvērš to siltuma enerǵijā;

- radikāḷ deaktivētāji (scavengers) - reaǵē ar brīvajiem radikāliem, kas rodas apstarošanas rezultātā, tādējādi pārtraucot ķ̣ēdes reakcijas;

- hidroperoksīdu sadalītāji (decomposers) - sadala fotooksidēšanās starpproduktus - hidroperoksīdus, neḷaujot tiem sadalīties caur radikāḷu veidošanās mehānismu. Tos sauc arī par sekundārajiem antioksidantiem.

Starp šìm klasēm nepastāv stingras robežas, jo UV absorberi var darboties arī kā slāpētāji, bet radikāḷu deaktivētāji var būt aktīvi hidroperoksīdu sadalītāji. Koksnes pārklājumos biežāk lietotie ir UV absorberi un radikāḷu deaktivētāji.

UV absorberi. UV absorberu galvenā funkcija ir absorbēt UV starojumu, pirms tas nav skāris aizsargājamo substrātu, transformējot absorbēto enerǵiju siltumā. Vēlams, lai UV absorbera molekulas spēj veikt šo ciklu atkārtoti. UV absorberu darbība pakḷaujas Bugēra-Lamberta-Bēra likumam, kas nosaka, ka starojuma absorbcija ir tieši proporcionāla absorbējošās vielas koncentrācijai un slāṇa biezumam. Tādēl ḷoti plānos pārklājuma slāṇos UV absorberu koncentrācijai jābūt pietiekoši augstai, lai efektīvi pasargātu substrātu (Bieleman et al., 2000).

Ir organiskie un neorganiskie UV absorberi. Koksnes pārklājumos biežāk lietoto organisko UV absorberu klases ir:

- benzotriazoli (benzotriazoles) - BTZ;

- hidroksifenil-s-triazīni (hydroxyphenyl-s-triazines) - HPT;

- benzofenoni (benophenones) - BP.

Tiem visiem ir līdzīgs darbības mehānisms, bet savs raksturīgs UV absorbcijas spektrs (Bieleman et al., 2000; Schaller and Rogez, 2007; Schaller et al., 2009). Nemot vērā, ka koksni kā substrātu ietekmē ne tikai UV, bet arī redzamās gaismas īsākie viḷni, 
ir izstrādāti UV absorberi ar uz garāko viļ̧nu galu pavirzītu raksturīgo absorbciju (Hayoz et al., 2003). Tomēr caurspīdīgos pārklājumos ir problemātiski nodrošināt visa spektra absorbciju, vienlaicīgi saglabājot nemainītu koksnes krāsu. Vēl viens organisko absorberu trūkumiem ir tas, ka tie paši ar laiku UV starojuma ietekmē degradējas un kḷūst neefektīvi (Gerlock et al., 1998; Blanchard and Blanchet, 2011). Ir novērots, ka UV absorberi efektivitāti var palielināt, palielinot to molekulmasu, tādējādi nodrošinot mazāku izskalošanos no koksnes (Evans and Chowdhury, 2010). Turklāt organiskie UV absorberi pēc savas dabas ir hidrofobi, tādēḷ tie ir speciāli jāpiemēro lietošanai pārklājumos uz ūdens bāzes (Schaller et al., 2009).

Koksnes pārklājumos biežāk lietotie neorganiskie absorberi ir metālu oksīdi, kas spēj absorbēt UV starojumu - cinka oksīds $(\mathrm{ZnO})$, titāna dioksīds $\left(\mathrm{TiO}_{2}\right)$, dažādi dzelzs oksīdi (Aloui et al., 2007; Clausen et al., 2010; Saha et al., 2011b). Biežāk tiek lietotas trīs dzelzs oksīdu formas: dzelzs (III) oksīds; dzelzs (III) oksīda hidrāts un magnetîts. Šie dzelzs oksīdi absorbē ne tikai UV starojumu, bet arī dažādus redzamās gaismas viḷnu apgabalus, tādēl to krāsu gamma variē no dzeltenas līdz melnai. Šie paši metālu oksīdi tiek lietoti arī kā pārklājumu pigmenti. Atkarībā no pigmentu izmēriem tie var veidot sedzošu vai caurspīdīgu pārklājumu (Schauwecker et al., 2014).

Neorganisko UV absorberu priekšrocība ir to stabilitāte pret UV starojumu. Tie var atšķirties pēc daļiņu izmēra un formas. Bieži tiek izmantoti nanoizmēra preparāti, kas lauj saglabāt pārklājuma caurspīdību. Tomēr ir konstatēts, ka nanoizmēra $\mathrm{TiO}_{2}$ un $\mathrm{ZnO}$ UV starojuma iedarbībā var tikt ierosināti un darboties kā pusvadītāji un, iedarbojoties uz blakus esošajām daļiņām, izraisīt brīvo radikāḷu veidošanos, kam var būt fungicīdas īpašības, bet vienlaicīgi tas var veicināt organisko polimērmateriālu (koksnes, pārklājuma saistvielas) fotodegradāciju (Lee et al., 2012; Filpo et al., 2013; Nikolic et al., 2015).

Radikāḷu deaktivētāji. Ir divu veidu radikāḷu deaktivētāji - cikliskie un necikliskie. To darbības pamatprincips ir saistīšanās ar brīvajiem radikāḷiem, tādā veidā pārtraucot radikāḷ reakcijas. Biežāk lietotie necikliskie radikāḷu deaktivētāji ir fenoliskie antioksidanti. Tos sauc arī par primārajiem antioksidantiem. To trūkums ir tas, ka pēc radikāḷa deaktivēšanas tie kḷūst neaktīvi. Ciklisko radikāḷu darbības mehānisms ir diezgan komplicēts, bet tas ietver pašu radikāḷu slāpētāju reǵenerēšanos, kas nodrošina to spēju iesaistīties jaunu radikāḷu deaktivēšanā (Step et al., 1994; Bieleman et al., 2000; Hayoz et al., 2003; Schaller et al., 2008). Tie tiek apzīmēti kā HALS (hindered amine light stabilizer), jo pamatā visi pārklājumu industrijā izmantotie cikliskie radikāḷ deaktivētāji ir dažādi 2,2,6,6-tetrametilpiperidīna atvasinājumi. Ir izstrādāts speciāli koksnei paredzēts radikāḷu slāpētājs, kas uzlabo lignīna aizsardzību pret fotodegradāciju un ko lieto kā ūdens šķīdumu tieši uz koksnes (Forsthuber and Grüll, 2010). Koksnes pārklājumos plaši tiek izmantota UV absorbera un HALS apvienošana vienā sastāvā. Turklāt ir novērots, ka HALS lietošana pagarina organisko UV absorberu dzīveslaiku (Bieleman et al., 2000; Forsthuber and Grüll, 2010).

Tiek meklētas arī dažādas jaunas, netradicionālas iespējas koksnes aizsardzībai pret fotodegradāciju. Piemēram, uzlabota krāsas stabilitāte un samazināta brīvo radikāḷu veidošanās ir novērota koksnei, kas pirms pakḷaušanas UV starojumam ir apstrādāta ar noteiktiem silīcijorganiskajiem savienojumiem (Baur and Easteal, 2012).

Mikroorganismi, kuri apdraud pārklātu koksni, ir - krāsojošās sēnes, aḷǵes un baktērijas. Baktērijas visnopietnāk apdraud pārklājumus uz ūdens bāzes pirms to uzklāšanas, kad baktērijas tos var degradēt, tādēl nepieciešami atbilstoši biocīdi (Bulian 
and Graystor, 2009). Nožuvušam pārklājumam biocīdiem galvenokārt jānodrošina pārklājuma rezistenci pret apaugšanu ar krāsojošām sēnēm un aļgீēm (Gillatt, 1996).

Krāsojošās sēnes var attīstīties gan kā hifu tīklojums, kas ir labi saistīts ar virsmu, gan kā konglomerāti, kas ir vāji saistīti ar virsmu un ar lietus ūdeni var tikt viegli noskaloti (Bardage, 1998). Uz koksnes virsmām ir atrasta ḷoti liela krāsojošo sēņu dažādība (Gillatt, 1996; Hernandez, 2012). Visbiežāk gan no nepārklātām, gan pārklātām koksnes virsmām izolētā suga ir Aureabasidium pullulanus (Stirling et al., 2011; Hernandez, 2012). Tas tiek skaidrots ar tās spēju izturēt ilgus sausuma periodus un augstas temperatūras, kā arī spēju sintezēt pietiekošu daudzumu melanīnu, kas absorbē UV starojumu, tādējādi paaugstinot sēnes rezistenci pret UV starojumu. Galvenie krāsojošo sēṇu augšanu ietekmējošie vides faktori ir: temperatūra, mitrums, skābeklis, sēņu sporas (Williams et al., 2000; Viitanen, 2002; Viitanen et al., 2010). Turklāt krāsojošo sēṇu attīstībā nav tik liela nozīme pašas koksnes mitrumam, kā apkārtējās vides mitrumam, kas nozīmē, ka arī laba koksnes aizsardzība pret mitrumu nevar pasargāt to no apaugšanas ar krāsojošām sēnēm (Reinprecht, 2010).

Krāsojošās sēnes ir spējīgas kolonizēt arī koksnes virsmu ar pārklājumu (Bardage, 1998, Gobakken and Lebow, 2010; Gobakken and Vestol, 2012). Ir konstatēts, ka krāsojošās sēnes aug gan uz ūdens, gan šḳīdinātāju bāzes koksnes pārklājumiem. Sēṇu augšanu uz pārklātām koksnes virsmām ietekmē piekḷuve barības vielām - plaisas pārklājumā ḷauj viegli piekḷūt papildus barībai. Krāsojošās sēnes nav tikai estētisks defekts. Tās ietekmē arī apkārtējā gaisa kvalitāti - tas tiek piesārņots ar sēņu sporām un gaistošiem savienojumiem (Viitanen et al., 2010). Turklāt sēņu kolonijām augot, var tikt bojāts pārklājums un koksne zem tā, kas ar laiku var atvieglot trupes sēnu attīstību. Tādēl neatṇemama koksnes pārklājuma funkcionālā piedeva ir fungicīdi.

Fungicīdi ir organiskas vai neorganiskas vielas, kas inhibē sēņu attīstību, un to darbības mehānisms ir galvenokārt atkarīgs no to ķīmiskās struktūras (Reinprecht, 2010). Fungicīdiem, kuri tiek lietoti koksnes pārklājumos, jābūt ar augstu pretsēņu aktivitāti, stabiliem pret UV starojumu, nešķīstošiem vai slikti šķ̄istošiem ūden̄i, lai tie netiktu izskaloti, labi savietojamiem ar pārklājuma citiem komponentiem (Gillatt, 1996). Ir novērots, ka krāsojošās sēnes ir relatīvi rezistentas pret aizsarglīdzekḷiem, kas paredzēti koksnes trupes sēņu inhibēšanai (Clausen and Yang, 2005; Ahmed et al., 2013b). Biežāk pārklājumos lietotie biocīdi ir IPBS, kas pieder karbamātu grupai, un propikanazols, kas pieder triazolu grupai (Viitanen, 2002; Reinprecht, 2010; Stirling et al., 2011).

Tiek meklētas arī arvien jaunas iespējas ierobežot koksnes apaugšanu, piemēram, lietojot melanīna biosintēzes inhibitorus, uz taukskābju bāzes veidotas virsmas aktīvas vielas, nanoizmēra sudraba dạ̧iņas, pārklājuma virsmas mikroprofilēšanu u.c. (Hernandez, 2012; Künniger et al., 2014; Stenbæk, 2015). Vēl viena stratēg̣ija, kā pasargāt virsmu no bioapaugšanas, ir apgrūtināt sēṇu piestiprināšanos tai, kas tiek panākts ar tā saucamo virsmas superhidrofobizāciju, ko sasniedz, kombinējot zemu virsmas enerğiju ar mikro- un nanodalịnām, kas samazina ūdens un virsmas saskares laukumu, kā rezultātā ūdens pilieni viegli noripo (Latthe et al., 2012).

\subsubsection{Pārklājumu ekspluatācijas īpašības atkarībā no to sastāva}

Koksne un pārklājums veido komplicētu materiālu sistēmu, kuras izturēšanos ekspluatācijas laikā nosaka gan pašas koksnes un pārklājuma īpašības, gan to savstarpējā mijiedarbība (Williams et al., 2000; Williams, 2009; Grüll et al., 2014). Tādēḷ pārklājuma kalpošanas laika prognozēšana ir komplicēts un komplekss pasākums, kur jāṇem vērā 
daudz dažādas savstarpējās materiālu un vides faktoru mijiedarbības (Deflorian et al., 2007; Croll and Hinderliter, 2008; Hardcastle and Meeks, 2008; Williams, 2009). Ir veikti plaši pētījumi par dažādu veidu koksnes pārklājumu, kā arī dažādu funkcionālo piedevu ietekmi uz pārklājumu spēju uzlabot koksnes saglabāšanos tās ekspluatācijas laikā.

Iesūkšanās koksnē. Viena no lioti svarīgām koksnes pārklājumu īpašībām ir to spēja iesūkties koksnē, tādā veidā veicinot labu adhēziju un funkcionālo piedevu (biocīdu, UV absorberu) ienešanu koksnē, nodrošinot maksimāli lielas koksnes daḷas tiešu aizsardzību. Ir gan arī pētījums, kura rezultāti norāda, ka iespiešanās dziḷums nav izšķirošais pārklājuma adhēziju nosakošais parametrs (Rijckaert et al., 2001a ). Salīdzinot alkīdu pārklājumus uz ūdens un šķ̄ininātāju bāzes, labāka adhēzija ir novērota alkīdiem uz škīininātāja bāzes (Meijer and Militz, 2000a). Turklāt pārklājuma iesūkšanās dziḷums ietekmē arī pārklājuma kopējo biezumu. Kopumā pārklājuma biezums, kas mainās atkarībā gan no virsmas apstrādes pirms pārklājuma uzklāšanas, gan uzklātā pārklājuma daudzuma, ir saistīts ar tā ilgtspējību - jo biezāks pārklājums, jo ilgāks laiks, līdz tas pats noārdās (Saha et al., 2011a). Biezāks pārklājums spēj arī absorbēt vairāk gaismas un laiž cauri mazāk ūdens (Feist, 1990b; Richter et al., 1995; Arnold, 2010b; Grüll et al., 2014).

Pārsvarā visos pētījumos, kuros tiek salīdzināts pārklājuma iesūkšanās dziļums koksnē, ir konstatēts, ka pārklājumi uz šḳīdinātāja bāzes spēj iesūkties koksnē dziḷāk nekā pārklājumi uz ūdens bāzes. Turklāt šāda tendence ir novērota, gan salīdzinot tradicionālos alkīdus uz šḳ̄indinātāja bāzes un akrilus uz ūdens bāzes, gan arī alkīdus uz šḳ̄īinātāja bāzes un ūdens bāzes savā starpā (Nussbaum et al., 1998; Meijer et al., 2001; Rijckaert et al., 2001a; Rijckaert et al., 2001b). Kā viens no iespējamiem iemesliem tiek minēts zemāks virsmas spraigums pārklājumiem uz šķ̄īinātāju bāzes, kas varētu veicināt pārklājuma iesūkšanos koksnē (Rijckaert et al., 2001b). Turklāt, jo lielāka viskozitāte, jo mazāk pārklājums iesūcas koksnē, bet pārklājuma viskozitāte palielinās, ja koksnes šūnu sieniņas uzsūc šḳīdinātāju, kā tas ir gadījumā, kad kā šḳīdinātājs tiek izmantots ūdens (Meijer et al., 2001). Iesūkšanās dziļumu ietekmē arī pigmentu klātbūtne pārklājumā pigmenti var samazināt pārklājuma iespiešanās dziḷumu (Rijckaert et al., 2001a). Pārklājuma iespiešanās dziḷumu koksnē nosaka ne tikai paša pārklājuma īpašības viskozitāte, žūšanas ātrums, saistvielas molekulmasa, bet arī koksnes substrāts. Iesūkšanās dziḷums koksnē ir l,oti nevienmērīgs, un arī uz vienas virsmas iesūkšanās dziļums var atšķirties pat līdz 10 reizēm. Tas ir saistīts ar koksnes anatomisko uzbūvi, jo iesūkšanās pa dažādiem koksnes struktūrelementiem atšķiras. Pārklājuma iesūkšanās process atšķiras arī lapkoku un skujkoku koksnei (Meijer et al., 1998; Nussbaum et al., 1998). Lai nodrošinātu labu pārklājuma iespiešanos koksnē, tam ir jābūt ar pietiekoši labām attiecīgā substrāta virsmas slapināšanas spējām.

Elastīguma saglabāšana. Otra ḷoti būtiska koksnes pārklājumu īpašība ir to elastība. Pārklājuma elastība nosaka, cik pārklājums būs izturīgs uz koksnes virsmas ekspluatācijas laikā, kad koksne mainīgos vides mitruma apstākḷlos mainīs savus lineāros izmērus. Svarīgs pārklājuma elastības rādītājs ir tā stiklošanās temperatūra $\left(\mathrm{T}_{\mathrm{g}}\right)$. $\mathrm{T}_{\mathrm{g}}$ ir temperatūra, kādā nekristālisks polimērs pāriet no stiklveida stāvokḷa uz vairāk amorfu stāvokli. $T_{g}$ ir svarīgs parametrs, lai varētu spriest par pārklājuma spēju izturēt stresus, kādi rodas pārklājumā koksnes deformāciju (briešana, rukšana) rezultātā (Aloui et al., 2006). Ja pārklājuma $T_{g}$ ir augstāka par ekspluatācijas vides temperatūru, tas atrodas tā sauktajā stiklveida stāvoklī, kam raksturīgs liels trauslums un līdz ar to, mainoties koksnes izmēriem, viegli veidojas plaisas. Turklāt pārklājumā, kas atrodas par tā $T_{g}$ zemākā temperatūrā, ir būtiski palielināts brīvais tilpums, kas rodas, veidojoties ciešākām 
saitēm starp pārklājumu veidojošām molekulām, un rezultātā palielinās pārklājuma caurlaidība. Novecošanās laikā pārklājuma Tg parasti pieaug (Podgorski et al., 1994; Aloui et al., 2006; Aloui et al., 2007). Polimēra T $\mathrm{T}_{\mathrm{g}}$ ietekmē virkne apstākḷu. Absorbētais ūdens padara polimēru plastiskāku un līdz ar to tā $T_{g}$ samazinās. Savukārt polimēra pakḷaušana UV starojumam izraisa ķīmiskās reakcijas, kuru rezultātā $\mathrm{T}_{\mathrm{g}}$ pieaug (Aloui et al., 2007). Ir konstaēts, ka alkīda krāsa novecojoties kḷūst trauslāka, jo palielinās šķērssaišu skaits un attiecīgi tās $\mathrm{T}_{\mathrm{g}}$ (Ploeger et al., 2009). Pētījumi ir parādījuši, ka šo procesu var palēnināt UV absorberu iekḷaušana pārklājuma sastāvā (Aloui et al., 2006). Ir novērots, ka arī plaisu veidošanās pārklājumā ir cieši saistīta ar tā $T_{g}$ paaugstināšanos (Aloui et al., 2007).

Aizsardzība pret mitrumu. Būtiska koksnes pārklājumu īpašība ir to spēja aizsargāt koksni pret mitrumu, jo viens no koksnes produktu kalpošanas ilglaicības pamatnosacījumiem ir nodrošināt koksnes relatīivu sausumu (Williams et al., 2000; Ekstedt, 2002b). Pārklājums uz koksnes virsmas attiecībā pret ūdeni darbojas kā membrāna - nel̦auj iesūkties šķidram ūdenim, bet l̦auj izplūst koksnē esošajam ūdenim tvaika veidā. Saskaroties ar ūdeni kā šksidrumu, ar pārklājumu aizsargātā koksnē viss ūdens ieiet tikai difūzijas ceḷā, un kapilārā uzsūkšana nenotiek (Meijer and Militz, 2000a). Koksnes uzturēšana relatīvi sausā stāvoklī nodrošina tās bioizturību, kā arī mazina stresus, kādi rodas koksnes briešanas un rukšanas rezultātā (Ekstedt, 2002b). Virknē pētījumu ir konstatēts, ka akrila un alkīda ūdens emulsijām ir raksturīga lielāka ūdens caurlaidība nekā alkīda pārklājumiem uz šķīdinātāja bāzes (Ahola et al., 1999; Meijer and Militz, 2000b; Van Meel et al., 2011; Siversten amd Flæte, 2012). Pārklājumam novecojoties, tā ūdens caurlaidība mainās, ko izraisa gan pārmaiṇas pašā pārklājuma materiālā, gan plaisu veidošanās (Ekstedt and Östberg, 2001).

Aizsardzība pret fotodegradāciju. Lai izceltu koksnes dekoratīvās īpašības, piemērotākie ir caurspīdīgie un daḹeji caurspīdīgie pārklājumi (Schaller and Rogez, 2007). Pie šīs grupas var pieskaitīt arī beices un el̦las. Mākslīgās novecināšanas testos ir konstatēts, ka eḷlas palēnina koksnes krāsas un ḳīmiskās izmaiṇas (Özgenc et al., 2013). Tomēr ne beices, ne eḷ,as būtiski nepasargā koksni no novecošanās (Jämsä et al., 2000; Temiz et al., 2007). Toties dzelzs oksīdi kā piedeva beicei samazina gan koksnes, gan paša pārklājuma novecošanos, kas tiek mērīta kā pārklājuma erozija (Feist, 1988).

Caurspīdīgo pārklājumu gadījumā jānodrošina gan koksnes, gan pārklājuma aizsardzība pret fotodegradāciju. Ir konstatēts, ka organisko UV absorberu lietošana šādos pārklājumos uzlabo koksnes aizsardzību pret plaisāšanu (Özgenc et al., 2012). Ne tikai UV starojums, bet arī redzamā gaisma līdz $500 \mathrm{~nm}$ var izraisīt lignīna degradāciju un jaunu hromoforo grupu veidošanos koksnē (Kataoka et al., 2007). Ja vēlams bezkrāsains pārklājums, nevar lietot redzamo gaismu absorbējošas vielas un nav iespējams pasargāt koksni no redzamās gaismas izraisītām pārmaiņām. Šādos gadījumos koksnes novecošanos var mazināt lietojot HALS, kas deaktivizē redzamās gaismas iniciētos brīvos radikāḷus.

Pētot pigmentētu pārklājumu novecošanos, novērots, ka, paaugstinot pigmentu koncentrāciju pārklājumā, tiek nodrošināta labāka aizsardzība, bet tā nepieaug proporcionāli pigmentu koncentrācijai (Feist, 1988; Grüll et al., 2014; Schauwecker et al., 2014). Ir arī konstatēts, ka pie augstākām pigmentu koncentrācijām papildus UV absorberu lietošana nemazina novecošanās procesus, jo augstā koncentrācijā arī paši pigmenti spēj absorbēt UV starojumu pietiekošā līmenī (Schauwecker et al., 2014). Visefektīgāko koksnes aizsardzību pret fotodegradāciju nodrošina pārklājums ar tik 
augstu pigmentu koncentrāciju, ka tas ir pilnībā koksni sedzošs (Aloui et al., 2007; Sivrikaya et al., 2011). Sedzošie pārklājumi ir arī rezistentāki pret apaugšanu ar krāsojošām sēnēm, jo augstais pigmentu saturs tajos nodrošina labāku paša pārklājuma aizsardzību pret saules starojuma ierosinātu degradāciju, bet sēņu kolonizācijas veicinoši faktori ir pārklājuma plaisāšana, lobīšanās un citi defekti (Gobakken and Lebow, 2010; Stirling et al., 2011).

Pigmentētu pārklājumu gadījumā ekspozīcijas laikā nozīme ir arī pigmentējuma tonim. Ir konstatēts, ka zem tumša pārklājuma āra apstākḷos eksponētas koksnes mitrums ir par 5\% zemāks nekā gadījumā, ja lietots tāda paša tipa gaišs pārklājums (Fredriksson, 2010). Tas ir izskaidrojams ar tumšā pigmentējuma absorbēto infrasarkano starojumu, kāa rezultātā ievērojami paaugstinās pārklātā substrāta temperatūra, kas veicina mitruma iztvaikošanu no koksnes.

UV absorberu lietošana pārklājumos nenovērš, bet mazina plaisu veidošanos un krāsu izmaiṇas novecināšanas procesā (Auclair et al., 2011; Özgenc et al., 2012; Schauwecker et al., 2013; Schauwecker et al., 2014). Labākie rezultāti koksnes aizsardzībā novecināšanas testos ir sasniegti, vienlaikus lietojot organiskos un neorganiskos UV absorberus (Mahltig et al., 2005; Auclair et al., 2011; Saha et al., 2011a). No organiskajiem absorberiem labākā spēja aizsargāt koksni ir konstatēta triazīnus saturošiem HPT tipa savienojumiem (Schaller et al., 2009; Forsthuber and Grüll, 2010; Schauwecker et al., 2013). Labas aizsardzības spējas ir uzrādījuši arī neorganiskie UV absorberi ( $\mathrm{ZnO}$ un $\mathrm{TiO}_{2}$ ) (Clausen et al., 2010; Özgenc et al., 2010; Auclair et al., 2011; Schauwecker et al., 2014). Ir novērots, ka metālu oksīdu piedevas var ietekmēt arī paša pārklājuma plēves veidošanās procesu - titāna dioksīds palēnina, bet cinka oksīds veicina pārklājuma žūšanu (Kalenda and Mene, 2009). Pētījumā, kurā koksnes aizsardzībai pret fotodegradāciju kā UV absorberis pārklājumam tika pievienots nanoizmēra $\mathrm{ZnO}$, tika konstatēts, ka ir zināma nanodaļiņu kritiskā koncentrācija, kuru pārsniedzot, to aizsargājošā efektivitāte vairs nemainās, kā arī, ka aizsardzības spēja ir atkarīga no nanodalinu izmēra un priekšapstrādes (Blanchard and Blanchet, 2011).

Atrasts, ka pārklājumi ar neorganiskajiem absorberiem $\left(\mathrm{TiO}_{2}, \mathrm{Fe}_{3} \mathrm{O}_{4}\right)$ novecošanās laikā sāk plaisāt ātrāk nekā pārklājumi ar organiskajiem UV absorberiem, kas tiek saistîts ar lielākām stiklošanās temperatūras izmain̄ām novecošanās procesā pārklājumiem ar neorganiskajiem absorberiem (Aloui et al., 2007).

Konstatēts, ka koksnes rezistenci pret fotodegradāciju ievērojami uzlabo priekšapstrāde ar hroma (VI) oksīda šķīdumu. Tas tiek skaidrots ar hroma spēju veidot ar lignīnu pret UV starojumu stabilus kompleksus. Tomēr hroma (VI) savienojumi ir atzīti par kait̄̄giem, tādēḷ to lietošana ḷoti daudzās valstīs, tai skaitā arī Eiropas Savienībā, ir ierobežota. Ar dzelzs (III) hlorīdu un nitrātu būtisks koksnes rezistences uzlabojums netika sasniegts (Evans et al., 1992).

Rezistence pret krāsojošām sēnēm. Pētîjumi par pārklātas koksnes apaugšanu ar krāsojošām sēnēm ir parādījuši, ka šo procesu vairāk ietekmē pārklājuma veids nekā koksnes substrāts (Gobakken and Westin, 2008; Gobakken and Høibø, 2011). Nav viennozīmīgu rezultātu, kura no koksnes pārklājumos biežāk lietotajām saistvielām alkīda vai akrila sveķi - ir izturīgāki pret apaugšanu āra ekspluatācijas laikā (Bardage, 1998; Viitanen, 2002; Gobakken and Lebow, 2010). Bet ir noskaidrots, ka īpaši ātri krāsojošās sēnes kolonizē pārklājumus uz linsēklu eḷıas bāzes (Bardage, 1998). Ar linsēklu eḷıu impregnēta koksne pēc 36 mēnešu āra ekspozīcijas pilnībā bija pārklājusies 
ar melnu bioplēvi, ko pamatā veidoja Aureobasidium pullulans. Tas norāda, ka ellıa ilgtermiņā nodrošina labvēlīgu vidi šīs sēnes attīstībai (Sailer et al., 2012).

Pētījumi ir parādījuši, ka biocīdu ietveršana pārklājumu sastāvā būtiski paaugstina to rezistenci pret kolonizāciju ar krāsojošām sēnēm. Pētījumos par biežāk lietoto biocīdu efektivitāti ir novērots, ka propikanazols viens pats nav pietiekoši efektīvs pārklājumu pasargāšanā no apaugšanas, bet kopā ar IPBS, kā arī IPBS viens pats uzrāda labu pretapaugšanas rezistenci (Viitanen, 2002; Gobakken and Westin, 2008; Gobakken and Lebow, 2010; Stirling et al., 2011). Ir arī konstatēts, ka pārklājumi, kuru sastāvos bez biocīdiem ir iekḷautas arī fotostabilizējošas vielas, spēj nodrošināt labāku aizsardzību pret apaugšanu ar krāsojošām sēnēm (Schaller and Rogez, 2007; Stirling and Morris, 2013). Pētījumā par pārklājuma virsmas fizikālo īpašību (gludums, cietība) ietekmi uz krāsojošo sēṇu virsmas kolonizāciju tika iegūti pārsteidzoši rezultāti, jo vairāk apaugušās bija gludo (spīdīgo) un cieto pārklājumu virsmas (Gobakken et al., 2010).

Termiski modificētas koksnes aizsardzība. Pētījumi par termiski modificētas koksnes novecošanos ir parādījuši, ka arī tai, lai saglabātu labu izskatu āra lietojumā, ir nepieciešams aizsargpārklājums. Ir pārbaudīts, ka nemodificētai koksnei paredzētie komerciālie pārklājumi var tikt lietoti termiski modificētai koksnei (Jämsä et al., 2000). Bet, līdzīgi kā nemodificētas koksnes gadījumā, arī termiski modificētu koksni pret novecošanos āra apstākḷos nepasargā bezpigmenta beices un eḷlas (Jämsä et al., 2000). Tāpat apstrāde ar ellıām ilgstošā laika periodā nepasargā termiski modificētu koksni pret ūdens absorbciju (Huang et al., 2012b). Apstrāde ar ellıu arī nenodrošina termiski modificētu koksni pret apaugšanu ar krāsojošām sēnēm (Fojutowski et al., 2011). Termiski modificētai koksnei mākslīgajā novecināšanā mazākas krāsas izmaiņas konstatētas, ja pirms pārklājuma koksne apstrādāta ar speciālu lignīna radikāḷus deaktivizējošu preparātu. Toties netika konstatētas būtiskas atšķirības krāsu izmaiņās termiski modificētai koksnei bez pārklājuma un ar caurspīdīgu pārklājumu, kas satur organisko un neorganisko UV absorberus (Saha et al., 2011b). Savukārt mākslīgās novecināšanas testos ar UV starojumu tika konstatēts, ka pigmentēts pārklājums krāsas izmaiņas ievērojami samazina (Deka and Petrič, 2008). Tiek meklēti arī jauni paṇēmieni un konstatēts, ka efektīva ir mizu ekstrakta pievienošana pārklājumam (Saha et al., 2011a; Saha et al., 2013). Termiski modificētas koksnes krāsas stabilizēšani pret UV iedarbību sekmīga bijusi arī koksnes apstrāde ar dzelzs (II) sulfāta šḳīdumu un ūdeņraža peroksīdu (Fentona reaǵentu) (Karlsson and Morén, 2010).

Tā kā apaugšanu vairāk ietekmē pārklājums nekā substrāts, pārklāta termiski modificēta un nemodificēta koksne apaug apmēram vienādi (Jämsä et al., 2000).

\subsection{Kopsavilkums}

Ir izstrādātas daudzas dažādas koksnes termiskās modifikācijas tehnoloǵijas, kurām visām kopēja ir koksnes apstrāde vidē ar ierobežotu skābekḷa daudzumu pie temperatūrām $\left(130-240^{\circ} \mathrm{C}\right)$, kas ir augstākas nekā tradicionāli koksnes žāvēšanai lietotās. Termiski modificētas koksnes īpašības ir atkarīgas gan no izmantotā kokmateriāla, gan var ḷoti plaši variēt atkarībā no konkrētajiem modifikācijas apstākḷiem: temperatūras režīma, apstrādes ilguma, vides. Lai arī konkrētiem modifikācijas apstākḷiem ir būtiska ietekme uz modificētās koksnes īpašībām, tomēr kopumā termiski modificētai koksnei ir līdzīgas raksturīgākās izmaiņas: masas zudumi, lielākas vai 
mazākas izmainas koksnes mikrostruktūrā, ievērojamas izmainas k̦īmiskajā sastāvā un krāsā, samazināts blīvums, koksnes līdzsvara mitrums un mehāniskā stiprība, bet paaugstināta dimensionālā stabilitāte, hidrofobitāte un bionoturība. Termiski modificētas koksnes relatīvi vājā mehāniskā stiprība ierobežo tās lietošanu slodzi nesošās konstrukcijās, toties izmainītā krāsa padara to pievilcīgu izmantošanai gadījumos, kad liela nozīme ir materiāla dekorativitātei. Pētījumos par termiski modificētu koksni pārsvarā dominē tās funkcionālo īpašību izpēte, un modifikācijas rezultātā izmainītā krāsa vairāk ir analizēta, kā viegli nosakāms materiāla raksturlielums, ko varētu izmantot citu īpašību prognozēšanai. Termiski modificēta koksne ir maz pētîta, un pētījumi ir fragmentāri no tās kā dekoratīva materiāla aspekta, tas ir, koksnes krāsas rakstura izmaiṇas atkarībā no modifikācijas temperatūras, krāsas vienmērība, krāsas variācija dažādos modificētā materiāla dzilumos.

Koksne āra apstākḷlos ir pakḷauta kompleksai ķīmisku, biologisku un mehānisku faktoru iedarbībai, kā rezultātā tā pakāpeniski, straujāk vai lēnāk, noārdās. Parasti koksnes novecošanās būtiski neietekmē izstrādājumu stiprību, bet ievērojami izmainās ar dekorativitāti saistītās īpašības - mainās koksnes krāsa, veidojas plaisas, virsma erozijas rezultātā kḷūst raupja. Galvenie abiotiskie atmosfēras faktori, kas ietekmē koksnes novecošanos, ir solārais starojums, mitrums, skābeklis un temperatūra, no kuriem saules starojuma UV un redzamās gaismas īsāko viḷnu dạ̣a ir atzīta par primāro cēloni koksnes izmaiṇām tās āra ekspozīcijas laikā. Pirmā redzamā koksnes novecošanās pazīme ir krāsas izmainas, kas ir saules starojuma izraisītu koksnes sastāvā esošu kịmisko komponentu fotooksidatīvo reakciju rezultāts. Ūdens neizraisa būtiskas kīmiskas izmaiņas koksnē, tomēr tas gan paātrina pašus fotooksidācijas procesus, gan izskalo fotodegradācijas produktus no koksnes virsmas un veicina plaisu veidošanos. Koksnes novecošanās process un galarezultāts ir atkarīgs gan no konkrētajiem tās ekspluatācijas apstākḷiem, gan pašas koksnes struktūras, tās mijiedarbības ar ūdeni īpatnībām, bet īpaši no tās ḳīmiskā sastāva, jo saules starojuma ierosinātie fotodegradācijas procesi ir tieši atkarīgi no starojumu absorbēt un tālākās reakcijās iesaistīties spējīgām ķīmiskajām struktūrām materiālā. Ir konstatēts, ka arī termiski modificēta koksne nav rezistenta pret novecošanos, bet tās izmainas novecošanās procesā atšķiras no nemodificētas koksnes izmain̄ām. Tomēr pētījumi par termiski modificētas koksnes novecošanās procesiem vairāk ir ar salīdzinošu raksturu, nevis procesus izzinoši.

Novecošanās procesu novēršana vai vismaz palēnināšana (mazināšana) ir koksnes dekoratīvo īpašību saglabāšanas pamatnosacījums. Mazināt saules starojuma koksni degradējošās spektrālās daḷas un ūdens iedarbību uz koksni ir iespējams, izmantojot piemērotus virsmas pārklājumus. Gan paša pārklājuma, gan koksnes aizsardzība pret saules starojuma ietekmi tiek nodrošināta ar dažāda rakstura funkcionālām piedevām, ko var lietot dažādās kombinācijās un daudzumos. Veidojot pārklājuma kompozīcijas, ir svarīgi atcerēties, ka tam jāatrodas līdzsvarā starp ekonomiskumu, draudzīgumu videi un funkcionalitāti. Lai to sasniegtu, pārklājumu kompozīcijas jāveido, ṇemot vērā substrāta īpatnības. Ir pētījumi par dažādu saules starojuma spektra apgabalu ietekmi uz nemodificētu koksni, kas ḷauj mērḳtiecīgi veidot tās aizsardzības sistēmas. Šādu pētījumu nav par termiski modificētu koksni, un tās spektrālā jutība, kas ir svarīgs faktors jebkura materiāla aizsardzības pasākumu izstrādāšanai, nav zināma. Zināšanas par to ļautu precīzāk izvēlēties atbilstošas pārklājumu piedevas maksimālas aizsardzības sasniegšanai.

Koksnei paredzētie pārklājumi galvenokārt atšķiras ar tajos izmantoto saistvielu un šḳ̄ininātāju, kura galvenā funkcija ir pārklājuma uzklāšanai piemērotas viskozitātes nodrošināšana. N̦emot vērā augošo tendenci samazināt naftas izcelsmes produktu izmantošanu, arvien aktuālāki kḷūst pārklājumi uz ūdens bāzes, kuru optimizēšanas 
iespējas tiek plaši pētîtas un kuri daḷēji sāk aizstāt tradicionālos alkīda pārklājumus uz organiskā šķ̄īinātāja bāzes. Tomēr pētījumi ir parādījuši, ka pagaidām alkīda pārklājumiem uz šḳīdinātāja bāzes ir virkne priekšrocību āra apstākḷlos lietotas koksnes aizsardzībā. Tie labāk iesūcas koksnē, izveidojot biezāku aizsargslāni, un nodrošina labāku aizsardzību pret mitrumu, kas ir būtiski, n,emot vērā koksnes hidrofīlo dabu. Turklāt pārklājumos uz ūdens bāzes izmantotās palīgvielas, lai izveidotu un stabilizētu emulsijas, ekspluatācijas laikā var izskaloties, kas ievērojami mazina šo pārklājumu ekologiskumu.

Pētījumos ir konstatēts, ka termiski modificētai koksnei ir izmantojami nemodificētai koksnei paredzētie pārklājumi, bet nav plašu pētījumu par pārklājumu sastāva optimizēšanu, ņemot vērā termiski modificētas koksnes būtiski izmainītās kīmiskās un fizikālās īpašības. Daḷas sintētisko sveḳu aizstāšana pārklājumos ar augu eḷıām un precīza funkcionālo piedevu izvēle varētu paaugstināt gan pārklājuma ekonomiskumu, gan draudzīgumu videi. 


\section{MATERIĀLI UN METODES}

\subsection{Izmantotie materiāli}

Darbā izmantotas divu Latvijā izplatītu lapkoku sugu - apses (Populus tremula L.) un baltalkšņa (Alnus incana (L.) Moench) - koksnes. Koksne dēḷu veidā $(1000 \times 100 \times 30 \mathrm{~mm})$ saņemta no dažādām Latvijas kokzāgeètavām. Visi izmantotie kokmateriāli bija bez redzamiem defektiem. Dēḷi pirms tālākas izmantošanas pētījumā vismaz mēnesi tika kondicionēti standartapstākḷıs: $20 \pm 2{ }^{\circ} \mathrm{C}$ temperatūrā pie relatīvā gaisa mitruma $(\mathrm{RH}) 65 \pm 5 \%$.

\subsection{Koksnes termiskā modifikācija}

Dēḷu termiskā modifikācija tika veikta dāṇu firmas WTT (Wood Treatment Technology) ražotā laboratorijas daudzfunkcionālā koksnes modifikācijas pilotiekārtā, kurā slēgtas vides modifikācijas process notiek ūdens tvaika vidē pie paaugstināta spiediena, kas l̦auj iegūt koksni ar būtiski mainītām īpašībām pie salīdzinoši zemām modifikācijas temperatūrām (2.1. att.).

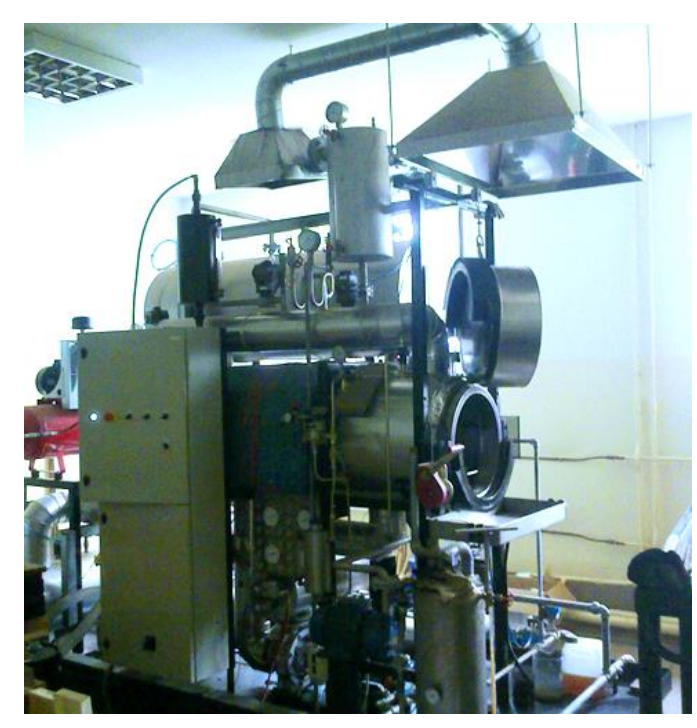

\section{1. att. WTT firmas daudzfunkcionālā koksnes modifikācijas pilotiekārta.}

Autoklāva raksturlielumi: iekšējais garums 1100 mm, iekšejais diametrs 410 mm, sildīšana procesa laikā tiek nodrošināta ar autoklāva apvalkā cirkulējošu eḷıu. Darbā tika izmantotas trīs termiskās modifikācijas temperatūras: divas temperatūras $\left(160^{\circ} \mathrm{C}\right.$ un $\left.170^{\circ} \mathrm{C}\right)$, kas, ņemot vērā iepriekšējo pētījumu rezultātus, ir atzītas par optimālām pētāmajām lapkoku sugām, kā arī viena temperatūra $\left(140^{\circ} \mathrm{C}\right)$, kas būtiski nemaina koksnes īpašības, bet ḷauj iegūt koksni ar izmainītu krāsu. Termiskās modifikācijas process sastāvēja no autoklāva vakuumēšanas pēc paraugu iekraušanas, lai mazinātu gaisa skābekḷa klātbūtni procesā, temperatūras pacelšanas līdz procesa maksimālajai temperatūrai un paraugu izturēšanas šajā temperatūrā, nodrošinot tvaika spiedienu autoklāvā 0.6 MPa. Tvaiks rodas, iztvaikojot koksnē esošajam mitrumam un autoklāvā pēc iepriekšēja aprēķina speciālā vannā iepildītajam ūdenim. Process tika vadīts automātiski, pamatojoties uz vadības sistēmā iepriekš ievadītiem procesa parametriem. 
Paraugi pirms un pēc modifikācijas tika svērti, un tiem tika noteikts mitruma saturs koksnē. Izmantojot šos datus, tika aprēķināti masas zudums termiskās modifikācijas rezultātā (\%) saskaṇā ar vienādojumu (2.1.).

$$
\text { Masas zudumi }=\left(1-\frac{m_{b}\left(100-W_{r e l}^{b}\right)}{m_{s}\left(100-W_{r e l}{ }^{s}\right)}\right) 100, \%
$$

kur:

$\mathrm{m}_{\mathrm{s}}-$ dēla masas pirms modifikācijas, $\mathrm{g}$;

$\mathrm{m}_{\mathrm{b}}$ - dēḷa masa pēc modifikācijas, g;

$\mathrm{W}_{\text {rel }}{ }^{\mathrm{s}}$ - koksnes relatīvais mitrums pirms modifikācijas, \%;

$\mathrm{W}_{\text {rel }}^{\mathrm{b}}$ - koksnes relatīvais mitrums pēc modifikācijas, \%.

Koksnes relatīvo mitrumu noteica, dēliem izzāgeèjot gabalus $(5-10 \mathrm{~cm})$ un izžāvējot žāvskapī pie temperatūras $102 \pm 3{ }^{\circ} \mathrm{C}$ līdz nemainīgai masai. Relatīvo mitrumu aprēḳināja saskaṇā ar formulu (2.2.).

$$
W_{\text {rel }}=\frac{m_{w}-m_{0}}{m_{w}} 100, \%
$$

kur:

$\mathrm{m}_{\mathrm{w}}$ - parauga masa pirms žāvēšanas, $\mathrm{g}$;

$\mathrm{m}_{0}-$ absolūti sausa parauga masa, $\mathrm{g}$.

\subsection{Koksnes raksturošanas metodes}

\subsubsection{Koksnes krāsas raksturošana}

Lai varētu konstatēt, kā koksne mainījusies izvēlētajā modifikācijas procesā un salīdzināt jauno materiālu ar nemodificētu koksni, pētījumā tika izmantoti gan nemodificētas, gan termiski modificētas koksnes paraugi.

Darbā koksnes krāsa raksturota izmantojot tās atstarošanas spektrus, kā arī Starptautiskās Apgaismojuma komisijas CIE (Commission Internatiomale de l'Eclairage) ieteiktu krāsu modeli CIELAB (2.2. att.).

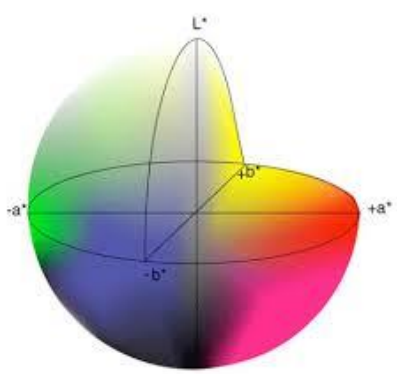

\section{2. att. CIEALB krāsu modelis (CIELAB 1976 ...).}

Lai modelis būtu pēc iespējas tuvāks cilvēka krāsu uztverei, tas tika izstrādāts, ņemot vērā perceptuāli psiholoǵiskus mērījumus. Šis modelis ḷauj atšķirīibas starp divām krāsām izteikt kvantitatīvi. CIELAB modelī krāsa tiek definēta ar gaišumu L* 
(ahromātiskā komponente) un krāsu komponentēm $a^{*}$ un $b^{*}$. Gaišuma vērtība var mainīties no 0 līdz 100, bet krāsu komponentes - robežās no -120 līdz +120 . Krāsainība $\mathrm{C}^{*}$ raksturo krāsas novietojumu $\mathrm{a}^{*}-\mathrm{b}^{*}$ plaknē, un lielāka tās vērtība nozīmē piesātinātāku krāsu, bet mazākas vērtības ir punktiem, kas tuvāki ahromātiskajai gaišuma $\mathrm{L}^{*}$ asij.

Atstarošanas spektri tika uzņemti ar portatīvu firmas MINOLTA spektrofotometru CM-2500d (Japāna), kurā atstarošanas spektru uzṇemšanai tiek izmantota difūza atstarošana integrējošā sfērā. N̦emot vēra koksnes virsmas relatīvo raupjumu, dati tika nolasīti SCI (Specular Component Included) režìmā, kurā tiek ņemta vērā atstarošanas spoguḷkomponente. Mērījumos izmantoti sekojoši parametri: starojuma avots - D65, saskaņošanas funkcija pie $10^{\circ}$, starojuma ǵeometrija $-\mathrm{d} / 8^{\circ}$, nolasī̌sanas laukums - Ø $8 \mathrm{~mm}$, automātisks vidējais rezultāts no diviem nolasījumiem vienā vietā. Spektri uzņemti starojuma apgabalā no 360 līdz $740 \mathrm{~nm}$ ar soli $10 \mathrm{~nm}$. Koksnes virsmas izmaiṇu procesu salīdzināšanai un analīzei izmantoti atstarošanas izmainu spektri, kas iegūti, atņemot katram viḷ,nu garumam atbilstošo atstarošanas vērtību procesa beigās no sākotnējās attiecīgā viḷna garuma atstarošanas vērtības. Pētot koksnes krāsas izmaiṇas novecošanas procesā, kā arī krāsas izmaiņas pēc dažādu caurspīdīgu pārklājumu izmantošanas, lai rezultātus neietekmētu koksnes virsmas krāsas nehomogenitāte, visi spektrofotometriskie mērījumi vienam un tam pašam paraugam visos gadījumos veikti vienās un tajās pašās marḳētās vietās. Katram paraugam spektrofotometriskie nolasījumi tika veikti ne mazāk kā piecās vietās, un parauga raksturošanai un tālākos aprēḳinos tika izmantoti katra parauga visu nolasījumu vidējie aritmētiskie lielumi.

Izmantojot programmatūru SpectraMagic NX Ver.1.4., no spektrofotometrisko mērījumu datiem automātiski aprēkināti CIELAB krāsu modela krāsu parametri L*, a*, b*, C*. Koksnes krāsas izmaiņas un atšķirības noteiktas, kā atsevišķu krāsu parametru starpības starp beigu $\left(\mathrm{L}^{*}, \mathrm{a}_{\mathrm{t}}, \mathrm{b}^{*}, \mathrm{C}^{*} \mathrm{t}\right)$ un sākuma lielumiem $\left(\mathrm{L}^{*}{ }_{0}, \mathrm{a}^{*}{ }_{0}, \mathrm{~b}^{*}{ }_{0}, \mathrm{C}^{*}{ }_{0}\right)$ koksnes novecināšanas un pārklāšanas gadījumā vai starpība starp diviem virsmas punktiem koksnes krāsas homogenitātes pētījumos:

$$
\begin{aligned}
\Delta L^{*} & =L^{*}{ }_{t}-L^{*}{ }_{0} \\
\Delta a^{*} & =a^{*}{ }_{t}-a^{*}{ }_{0} \\
\Delta b^{*} & =b^{*}{ }_{t}-b^{*}{ }_{0} \\
\Delta C^{*} & =C^{*}{ }_{t}-C^{*}{ }_{0}
\end{aligned}
$$

Kopējās krāsu izmaiņas/atškirīības $\Delta$ Eabt CIELAB krāsu modelī tiek definētas kā ǵeometriskais attālums starp diviem trīsdimensionālas telpas punktiem (2.3. att.).

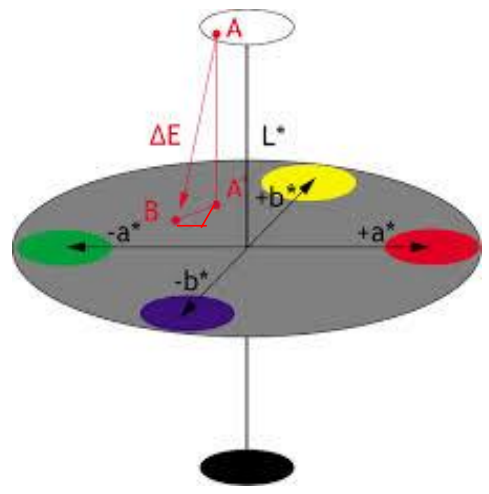

2.3. att. Krāsu atšḳirīibu shematisks attēlojums. 
Krāsu atšḳirības $\Delta$ Eab tiek aprēḳinātas pēc formulas (2.7.).

$$
\Delta E a b=\sqrt{\left(\Delta L^{*}\right)^{2}+\left(\Delta a^{*}\right)^{2}+\left(\Delta b^{*}\right)^{2}}
$$

\subsubsection{Koksnes krāsas homogenitātes noteikšana}

Koksnes krāsas homogenitāte tika noteikta, spektrofotometriski nosakot koksnes paraugu krāsu parametrus L*, a*, b* (CIELAB krāsu modelis) un aprēḳinot krāsu atšķirības $\triangle \mathrm{Eab}$ saskaṇā ar vienādojumu (2.7.). Koksnes krāsas homogenitāte tika noteikta dažādos līmeņos.

(1) Viena dēḷa ietvaros vienā plaknē. Gan nemodificētai, gan termiski modificētai koksnei uz noēvelētas dēla virsmas $(1000 \times 100 \mathrm{~mm}) 15$ nejauši izraudzītās vietās tika noteikti krāsu parametri un, izmatojot vienādojumu (2.7.), aprēkinātas krāsu atšķirības starp šìm vietām, tādējādi iegūstot $105 \Delta$ Eab vērtības katram dēlim. Krāsu parametri tika noteikti 12 dēliem uz abām lielajām skaldnēm. Rezultāti tika apkopoti un analizēti, izmantojot kastīšu diagrammas.

(2) Starp dēḷiem. Desmit nemodificētiem dēḷiem 15 brīvi izraudzītās virsmas vietās tika noteikti krāsu parametri $\left(\mathrm{L}^{*}, \mathrm{a}^{*}, \mathrm{~b}^{*}\right)$. Tad katrs dēlis $(1000 \times 100 \mathrm{~mm})$ tika sazāǵêts 3 daḷās $(300 \times 100 \mathrm{~mm})$ un no katra dẹla pa vienai daḷai modificēta katrā no šajā pêtījumā izmantotajām modifikācijas temperatūrām $\left(140^{\circ} \mathrm{C}, 160^{\circ} \mathrm{C}, 170^{\circ} \mathrm{C}\right)$. Tādā veidā tika nodrošināts, ka dažādos režīmos modificētas koksnes krāsas homogenitātes rezultātus pēc iespējas mazāk ietekmē izejas materiāla atšķirības. Pēc termiskās modifikācijas katram dēlim 15 brīvi izraudzītās vietās uz abām lielajām skaldnēm tika noteikti krāsu parametri $\left(L^{*}, a^{*}, b^{*}\right)$ un aprēḳinātas šo parametru vidējās vērtības viena dēļa ietvaros. Izmantojot šīs katra dēḷa krāsu parametru vidējās vērtības, saskaņā ar vienādojumu (2.7.) tika aprēḳinātas $\Delta$ Eab krāsu atšķirības starp dēliem, kas bija modificēti vienā režīmā.

(3) Modificēta dēẹa dažādos dziḷumos no virsmas. Dažādos termiskās modifikācija režīmos modificēti dēḷi $(300 \times 100 \mathrm{~mm})$, kam pēc modifikācijas bija noteikti virsmas krāsu parametri, katrs tika sazāgeēts četrās $(70 \times 100 \mathrm{~mm})$. Iegūtajām daḷām ar soli $2 \mathrm{~mm}$ no abām pusēm tika noēvelēta virsma, tādā veidā no katra dēḷa iegūstot paraugus, kuru abu lielo skaldņu virsmas reprezentēja attiecīgi 0, 2, 4 un $6 \mathrm{~mm}$ dziḷumu no modificēta dēḷa abām virsmām. Katrai no š̄im virsmām piecās vietās tika veikti spektrofotometriskie mērījumi, uzņemot atstarošanas spektrus un nosakot krāsu parametrus ( $\left.\mathrm{L}^{*}, \mathrm{a}^{*}, \mathrm{~b}^{*}\right)$. No iegūtajiem datiem tika aprēḳinātas vidējās vērtības un krāsu atšḳirības starp dēḷa virsmu un dziḷākajiem slāṇiem.

\subsubsection{Koksnes virsmas ḳīmiskā sastāva noteikšana}

Koksnes virsmas kịmiskā sastāva izmaiņas mākslīgās un dabīgās novecošanas procesos kontrolētas spektroskopiski, izmantojot Furjē transformācijas infrasarkanās spektroskopijas (FTIR) metodi, nosakot koksnei raksturīgo funkcionālo grupu absorbcijas izmaiņas. Absorbcijas spektri uzṇemti ar Perkin-Elmer Spectrum One spektrometru (ASV) ar ATR papildierīci, kas lauj uznemt cietu vielu virsmas spektrus. Spektri uzņemti $600-4000 \mathrm{~cm}^{-1}$ apgabalā, un katrs spektrs iegūts, paraugu skenējot 64 reizes. Spektri normalizēti attiecībā pret absorbcijas maksimumu pie $1030 \mathrm{~cm}^{-1}$, un absorbcija izteikta absorbcijas vienībās, pieņemot, ka lielākā absorbcijas maksimuma augstums ir 1.5 vienības. Pirms spektru uzṇemšanas paraugi 24 stundas žāvēti 
vakuumskapī $40^{\circ} \mathrm{C}$ temperatūrā un turpmāk uzglabāti eksikatorā ar fosfora pentoksīdu kā mitrumu saistošo aǵentu. Novecināšanas testam, kurā tika noteiktas koksnes virsmas ķīmiskās izmaiņas UV starojuma un saules starojuma ietekmē, attiecīga izmēra paraugi tika sagatavoti pirms novecināšanas testa. Savukārt testā, kurā ķīmiskās izmaiņas tika noteiktas pēc koksnes novecināšanas zem dažādiem filtriem, paraugi FTIR ATR analīzei tika ar žileti izgriezti no jau novecinātas koksnes virsmas.

Koksnes elementanalīze veikta saskaņā ar standartu LVS EN ISO 16948:2015 izmantojot elementanalizatoru Vario MACRO CHNS: "Elementar Analysensysteme GmbH" (Vācija). Kā standartviela sadedzināšanas kolonnas kalibrēšanai un faktora noteikšanai izmantots sulfanilamīds. Nesējgāzes hēlija plūsma $-500 \mathrm{~mL} \mathrm{~min}{ }^{-1}$. Paraugi ( $30 \mathrm{mg}$ ) no novecinātas koksnes sagatavoti ar skalpeli nokasot virsējo kārtu, references paraugi sasmalcināti. Pirms elementanalīzes veikšanas paraugi 24 stundas žāvēti vakuumskapī $40^{\circ} \mathrm{C}$ temperatūrā un turpmāk uzglabāti eksikatorā ar fosfora pentoksīdu kā mitrumu saistošo aǵentu.

Lai noteiktu termiski modificētas koksnes krāsu veidojošo hromoforu grupu saistību ar koksnes ķīmiskajiem elementiem, tika veikta modificētas koksnes ekstrakcija ar karstu ūdeni un acetonu. Ekstrakcija tika veikta ar mikrotomu nogrieztām $500 \mu \mathrm{m}$ biezām termiski modificētas koksnes plāksnītēm, tās Soksleta aparātā ekstragèejot 8 stundas acetonā un destilētā ūden̄i saskaṇā ar vispārpieņemtām koksnes ekstraǵěšanas metodēm (Zaķis, 2008). Ekstraktvielu saturs koksnē tika aprēķināts no masas zudumiem ekstrakcijas laikā. Pirms un pēc ekstrakcijas plāksnītēm tika veikti spektrofotometriskie mērījumi.

\subsubsection{Koksnes virsmas mikrostruktūras analīze ar SEM}

Koksnes virsmas strukturālās izmaiņas novecināšanas laikā tika pētītas, izmantojot skenējošo elektronu mikroskopiju (SEM). Iepriekš vakuumā izžāvēti paraugi $(5 \times 5 \times 2 \mathrm{~mm})$ pirms mikroskopēšanas tika pārklāti ar zelta kārtinuu, izmantojot uzputinātāju EMITECH K550X. Attēli tika iegūti ar SEM mikroskopu SEN TESCAN TS 5136 MM (Čehija), skenēšanu veicot pie $20 \mathrm{kV}$ liela sprieguma un izmantojot atstaroto elektronu detektoru. Attēli tika uzṇemti ar palielinājumu no 200 līdz 1000 reizēm. Iegūto datu un attēlu apstrāde tika veikta ar VEGA TC programmatūru Windows $\mathrm{XP}^{\mathrm{TM}}$ vidē.

\subsection{Koksnes novecināšanas testi}

Visos eksperimentos, kuros tika pētīta koksnes novecošanās procesi, paraugi pēc to sagatavošanas - sazāgeěšanas attiecīgajos izmēros un virsmas noēvelēšanas vismaz desmit dienas tika kondicionēti standartapstākḷıs $\left(20 \pm 2{ }^{\circ} \mathrm{C}, 65 \pm 5 \% \mathrm{RH}\right)$ pirms izejas mērījumu izdarīšanas.

\subsubsection{Dabīgā novecināšana}

Dabīgā novecināšana tika realizēta dažādos apstākḷıs. 
(1) Koksnes novecošanās oksidatīvu procesu rezultātā, kad tā nav pakḷauta būtisku, agresīvu vides faktoru iedarbībai, tika novērtēta eksperimentā, kurā paraugi (100 $\times 100 \mathrm{~mm}$ ) tika turēti iekštelpās tumsā - tie bija pasargāti no visa veida gaismas starojuma ietekmes, bet bija pakḷauti ikdienas temperatūras un relatīvā mitruma (RH) svārstībām iekštelpās. Paraugi tika izṇemti gaismā tikai kārtējo mērījumu izdarī̌sanai.

(2) Paraugi $(100 \times 100 \mathrm{~mm})$, tika turēti iekštelpās ikdienas apgaismojumā (dienasgaisma caur loga stiklu un mākslīgais apgaismojums), bet pasargājot tos no tiešiem saules stariem.

(3) Koksnes novecošanās pilna saules starojuma ietekmē tika novērota, paraugus $(70 \times 70 \mathrm{~mm})$ ievietojot speciāli pagatavotos rāmjos un tos solārās vasaras laikā (no 7. maija līdz 6. augustam) saulainās dienās novietojot uz horizontālas virsmas vietā, kur tie ir pakḷauti tiešiem saules stariem.

(4) Koksnes novecošanās saules starojuma caur loga stiklu (sun through window glass) ietekmē tika novērota pilna saules starojuma testam (3) paralēlā testā, paraugus aizsedzot ar dubultu $3 \mathrm{~mm}$ biezu loga stiklu paketi. Loga stikls galvenokārt bloḳē saules spektra UV starojuma īsāko viḷnu apgabalu (2.4. att.).

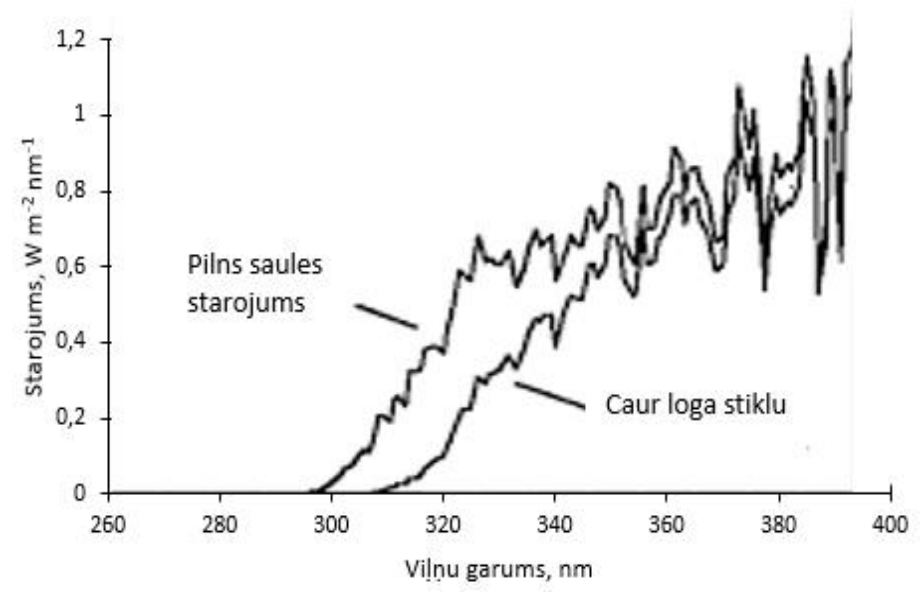

\section{4. att. Pilna saules un saules caur loga stiklu starojumu spektri UV apgabalā} (QUV and Weathering...).

Gan pilna saules, gan saules caur loga stiklu spektra UV dalas $(290-390 \mathrm{~nm})$ starojuma intensitāte tika kontrolēta ar portatīvu firmas Lutron Electronic Enterprise radiometru UV-340 (Taivāna), kura radiācijas sensora uzbūves pamatā ir UV foto diode un UV krāsu korekcijas filtrs ar caurlaidības spektru starojuma viḷnu $290-390 \mathrm{~nm}$ apgabalā. Saules starojuma intensitāte uz paraugu virsmas tika fiksēta reizi stundā nosakot kopējo UV starojuma intensitāti Euv, kas tālāk tika pārrēķināta parauga saņemtajā UV enerğijas daudzumā uz kvadrātmetru Huv saskaṇā ar formulu (2.7.).

$$
H_{U V}=E_{U V} \cdot t, J m^{-2}
$$

kur:

$$
\begin{aligned}
& \mathrm{E}_{\mathrm{UV}} \text { - starojuma intensitāte, } \mathrm{W} \mathrm{m}^{-2} \text {; } \\
& \mathrm{t} \text { - parauga eksponēšanas laiks, } \mathrm{s} \text {. }
\end{aligned}
$$

Paraugi saules gaismai tika eksponēti tikai tad, ja saules pilna UV starojuma intensitāte uz paraugu virsmas EUv bija lielāka par $10 \mathrm{~W} \mathrm{~m}^{-2}$. Laikā, kad paraugi netika 
eksponēti saules starojumam, tie tika glabāti istabas apstākḷos tumsā. Pilna saules starojuma intensitātes dati atbilstošām stundām tika iegūti no Latvijas Vides, G̣eologijas un Meteorologijas centra datu bāzes (LVG̣M).

(5) Lai novērtētu atsevišķu saules starojuma spektru apgabalu ietekmi uz termiski modificētas koksnes novecošanās procesiem, tika izgatavotas konstrukcijas ar virsmā iestiprinātiem stikla filtriem, kuriem ir dažādi gaismas caurlaidības spektri (2.5. att.). Filtru diametrs $-30 \mathrm{~mm}$.

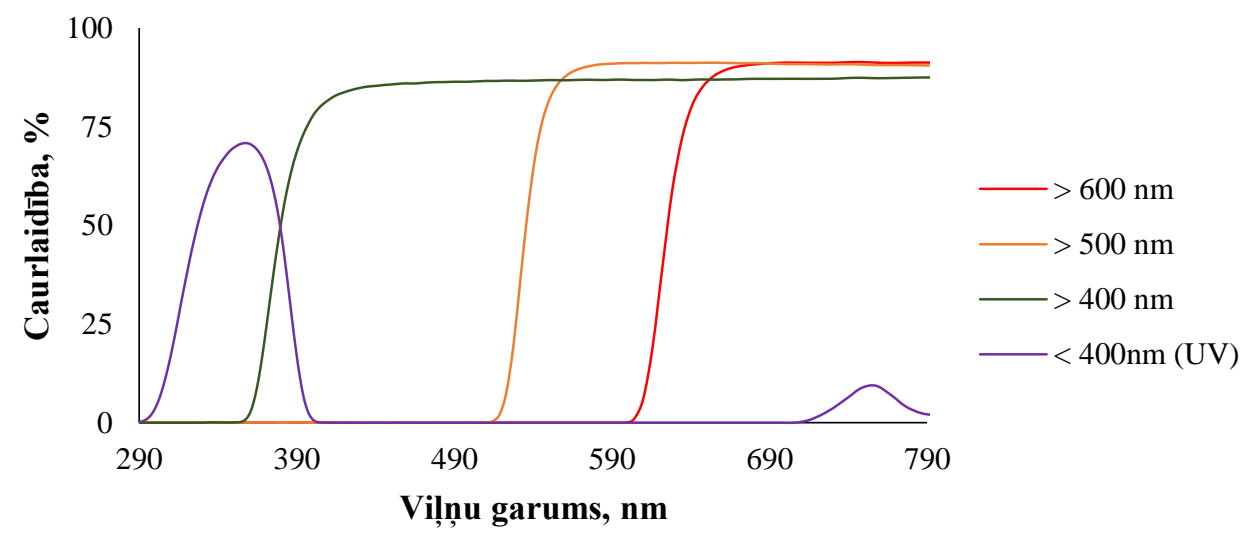

\section{5. att. Filtru starojuma caurlaidības spektri UV-redzamās gaismas apgabalā.}

Šajā testā, lai mazinātu dabīgo koksnes atškirīību ietekmi uz rezultātiem, paraugi tika sagatavoti tā, lai zem katras filtru sērijas būtu izvietoti paraugi no viena dēḷa. Paraugu izmēri $-80 \times 60 \times 20 \mathrm{~mm}$. Tests tika realizēts analogi pilna saules starojuma ietekmes novērtēšanas testam (3).

\subsubsection{Mākslīgā novecināšana}

Mākslīgā novecināšana tika veikta firmas Q-Lab (ASV) mākslīgās novecināšanas kamerā QUV (2.6. att.).
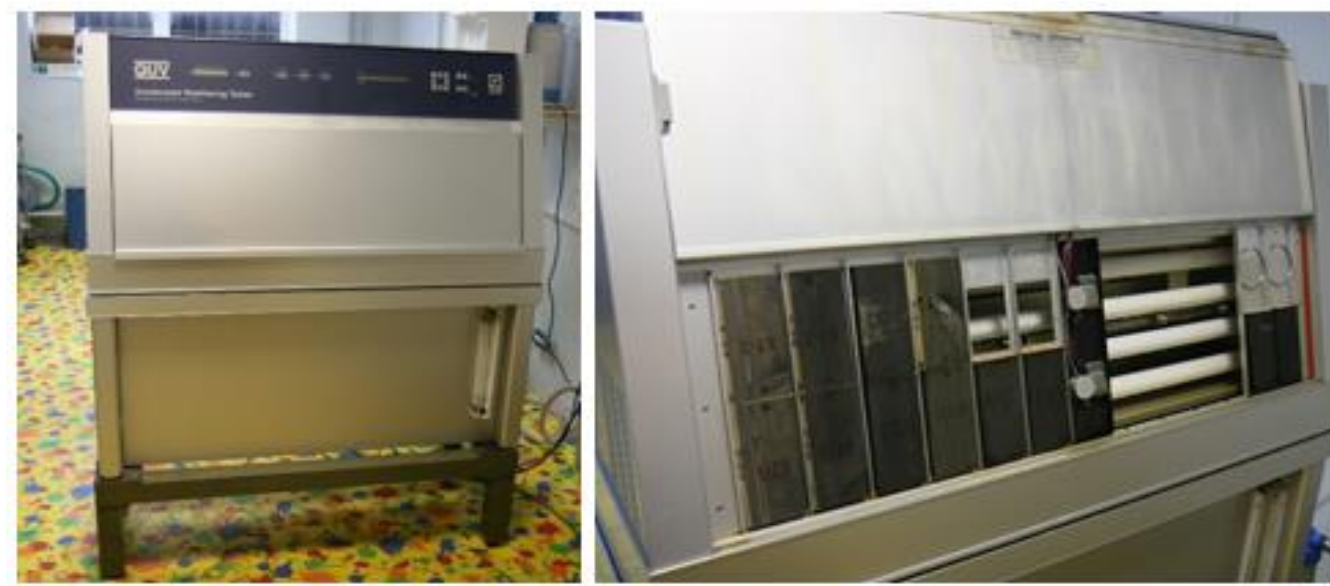

2.6. att. Mākslīgās novecināšanas kamera QUV. 
UV starojuma avots kamerā ir fluorescentās UVA-340 tipa lampas, kuras emitē starojumu ar maksimālo intensitāti pie 340 nm (2.7. att.). Kā redzams, šīs lampas labi imitē saules starojuma īsāko viḷnu apgabalu $(290$ - $360 \mathrm{~nm})$, bet to starojuma spektrā, salīdzinot ar saules starojumu, ir relatīvi mazs garāko UV viḷ,nu īpatsvars.

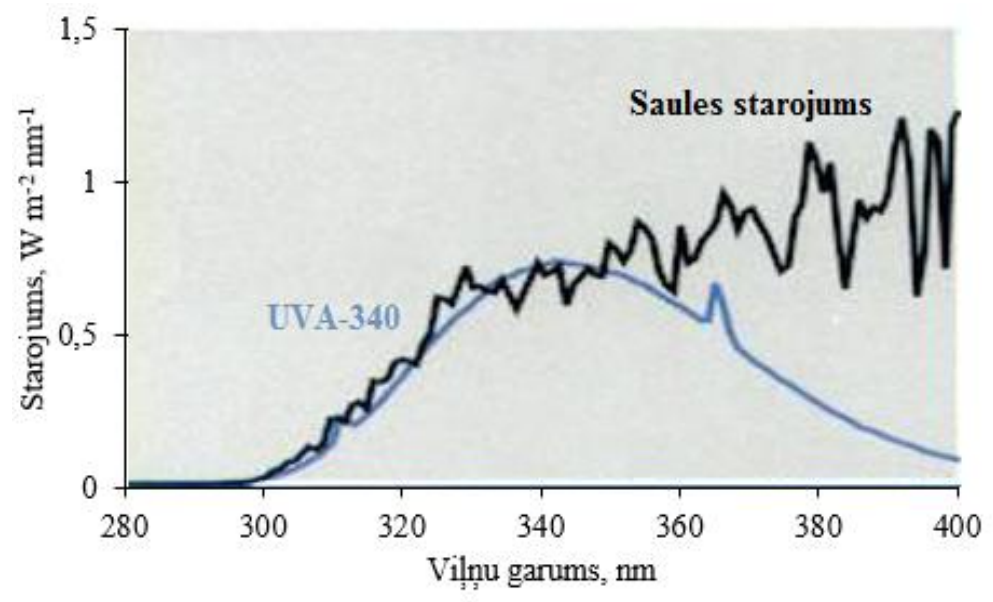

\section{7. att. Fluorescento UVA-340 lampu starojuma spektrs (QUV \& Weathering....).}

Pamatā pētījumos tika izmantota starojuma intensitāte $0,89 \mathrm{~W} \mathrm{~m}^{-2}$ pie $340 \mathrm{~nm}$, izņemot pētījumu ar paaugstinātu UV intensitāti (UV- max), kad starojuma intensitāte pie $340 \mathrm{~nm}$ bija $1.36 \mathrm{~W} \mathrm{~m}^{-2}$. Paraugu izmēri novecināšanas kameras eksperimentos ir $70 \times 150 \times 15 \mathrm{~mm}$. Lai pēc novecināšanas testa nebūtu vairs jāveic speciāla apstrāde mikroskopijas paraugu sagatavošanai, SEM analīzei paredzētie paraugi jau pirms novecināšanas tika sagatavoti mikroskopijai atbilstošā izmērā un pielīmēti organiskā stikla vairogiem, kuri tika iestiprināti novecināšanas kameras paraugu rāmjos. Pētījumā tika izmantoti divi mākslīgās novecināšanas režīmi: (1) UV režīms - UV apstarošana $60^{\circ} \mathrm{C}$ temperatūrā; (2) pilnā cikla režīms (PC) - standartā EN 927-6 paredzētais režīms, kas paredz paraugu $24 \mathrm{~h}$ kondicionēšanu pie $100 \% \mathrm{RH}$ un $45 \pm 3^{\circ} \mathrm{C}$ temperatūrā, kam seko 48 cikli, kas sastāv no $2,5 \mathrm{~h}$ apstarošanas pie $60 \pm 3^{\circ} \mathrm{C}$ temperatūras un $0.5 \mathrm{~h}$ apsmidzināšanas ar destilētu ūdeni. Testu ilgums, atkarībā no pētāmajiem paraugiem un izmantotā režīma, bija atšḳirīgs. Testi ik pēc zināmiem laika periodiem tika apturēti, lai paraugiem veiktu spektrofotometriskos mērījumus, tādējādi iegūstot datus par novecošanās procesu dinamiku.

\subsection{Pārklājumu pagatavošana, raksturošana, testēšana}

\subsubsection{Pārklājumu pagatavošana}

Visiem laboratorijā gatavotajiem pārklājumiem vispirms tika pagatavots bāzes sastāvs, kurā, atkarībā no receptūras, tika izmantoti: šķīinātājs - vaitspirts NESSOL LI 200; saistvielas - rūpnieciski pagatavoti alkīda sveḳi, kā arī linsēklu eḷla un linsēklu eḷ,as pernica; eḷllas žūššnas veicinātājs (sikatīvss) - kobalta naftenāts; biocīds - Wocosen 45 TK (satur $34 \%$ propikonazolu un $16 \%$ IPBC - jodo-propinil-butil-karbamātu); pretplēves reaǵents Exkin 2. Bāzes sastāvs tika pagatavots, pēc receptūras, ar precizitāti $\pm 0.01 \mathrm{~g}$ iesverot un ar maisītāju samaisot (10 - 15 min) šḳidinātājus un saistvielas, tad pa vienam 
pievienojot sikatīvu, biocīdus, pretplēves reaǵentu, katru reizi samaisot līdz viendabīgai konsistencei. Konkrētais pārklājums tika iegūts, bāzes sastāvam pievienojot specifiskās attiecīgā pārklājuma piedevas: (1) Tinuvin 5060 (satur organisko UV absorberi uz 2-(2hidroksifenil)-benzotriazola (BTZ) bāzes un uz tetrametilpiperadīna atvasinājumu bāzes izveidotu polifunkcionālu brīvos radikāl̨us dezaktivējošu savienojumu (HALS); (2) HOMBITEC RM 400 (satur neorganisko UV absorberi - $\mathrm{TiO}_{2}$ ); (3) NANOBYK-3821 (satur neorganisko UV absorberi - ZnO); (4) Sicoflush ${ }^{\circledR}$ L Yellow 1916 C4 (caurspīdīgu nano izmēra dzelzs oksīdu hidrātu maisījumu pigmentu pasta); (5) Sicoflush ${ }^{\circledR}$ L Red 2817 C4 (caurspīdīgu nano izmēra dzelzs (III) oksīda pigmentu pasta). Pagatavotie pārklājumi tika glabāti noslēgtos traukos istabas apstākḷos. Pārklājumu kompozīcijas, izvēloties saistvielas un to daudzumu gatavojamajā pārklājumā, tika veidotas tādas, kas nenosedz koksnes struktūru un neveido redzamu virsmas plēvi, tādā veidā ḷaujot maksimāli saglabāt termiski modificētas koksnes dabīgo izskatu. Pārklājumi uz koksnes tika uzklāti ar otu. Uzklātais pārklājuma daudzums tika fiksēts, paraugu sverot pirms (ar precizitāti $0.01 \mathrm{~g}$ ) un tūlīt pēc pārklājuma uzklāšanas un, izmantojot iepriekš noteikto attiecīgā pārklājuma sauso atlikumu, pārrēḳināts uz uznesto sausā pārklājuma daudzumu $\left(\mathrm{g} \mathrm{m}^{-2}\right)$. Paraugiem tika uzklāti trīs slāṇi - gruntsslānis un divi virsslāṇi. Iepriekšêjam slānim ḷāva žūt vismaz 24 stundas pirms nākošā pārklājuma slāṇa uzklāšanas.

\subsubsection{Pārklājumu raksturošana}

Pārklājumu viskozitāte tika kontrolēta un salīdzināta, izmantojot Ford kausa tipa viskozimetru B3 - 246 (Krievija) ar darba tilpumu $100 \mathrm{~mL}$. Tika mērīts pārklājuma šķīduma iztecēěanas laiks sekundēs ar precizitāti $\pm 1 \mathrm{~s}$. Šķīduma iztecēšanas laiks ir proporcionāls kinētiskajai viskozitātei. Viskozitātes noteikšanas laikā tika kontrolēta un uzturēta šksīduma temperatūra $20 \pm 0.5^{\circ} \mathrm{C}$.

Pārklājumu šḳīdumu blīvums $\left(\mathrm{g} \mathrm{cm}^{-3}\right)$ tika noteikts, iepriekš nosvērtā sverglāzî̀tē ar pipeti iepildot $10 \pm 0.1 \mathrm{~mL}$ šķīduma un nosverot. Blīvuma noteikšanas laikā tika kontrolēta un uzturēta šḳīduma temperatūra $20 \pm 2{ }^{\circ} \mathrm{C}$.

Pārklājuma sausais atlikums (\%) tika noteikts, iepriekš nosvērtā metāla trauciņā iesverot (ar precizitāti $0.01 \mathrm{~g}$ ) paraugu un to žāvējot termoskapī $140 \pm 2{ }^{\circ} \mathrm{C}$ temperatūrā līdz nemainīgam svaram, pirmo svara kontroli veicot pēc 1 stundas.

Pārklājumu stiklošanās temperatūra $\mathrm{T}_{\mathrm{g}}$ tika noteikta, izmantojot diferenciālo skenējošo kalorimetriju (DSC - differential scanning calorimetry). Analīzei tika izmantots kalorimetrs Mettler Toledo 82E (Malaizija), temperatūras celšanas intervāls no $-50^{\circ} \mathrm{C}$ līdz $+100^{\circ} \mathrm{C}$, temperatūras celšanas ātrums $10^{\circ} \mathrm{C}$ minūtē. $\mathrm{T}_{\mathrm{g}}$ noteikšanai no pagatavotajiem pārklājumu šķ̄īumiem tika izgatavotas plēves, tos iepildot uz politetrafluoretilēna (teflona) plāksnes izveidotās formās ar aprēķinu, lai iegūtu aptuveni $100 \mu \mathrm{m}$ biezas plēves. Pārklājumi tika žāvēti istabas apstākḷlos $\left(20 \pm 2^{\circ} \mathrm{C} ; 40 \pm 5 \% \mathrm{RH}\right)$ līdz nemain̄̄gai masai. $T_{\mathrm{g}}$ noteikšanai no pārklājuma plēves tika atdalīti gabaliṇi ar kopējo masu $0.08 \mathrm{~g}$.

\subsubsection{Pārklājumu testēšana}

Virsmas hidrofobitāte tika mērīta, nosakot kontaktleņķi sistēmai <koksne ar pārklājumu-ūdens piliens>. Kontaktleņ̧⿻̧一 mērīšanai tika izmantota iekārta Dataphysics OCA20 (Vācija), kas ir apgādāta ar videokameru un programmatūru piliena formas, kontakta leṇķa un cietas virsmas brīvās enerğijas noteikšanai. Kontaktleṇķis tiek definēts 
kā leṇkisis starp cietās virsmas bāzes līniju un piliena kontūras tangenti, kura iet caur cietās vielas-šķidruma-gaisa saskares punktu. No piliena kontūras iegūst divas kontaktleṇķa vērtības - kreisajam un labajam saskares punktam, un sistēmu raksturojošasis kontaktleņkisis ir šo divu lielumu vidējā vērtība. Pirms analīzes paraugi tika kondicionēti $20 \pm 2{ }^{\circ} \mathrm{C}$ temperatūrā pie RH $65 \pm 5 \%$ līdz līdzsvara mitruma sasniegšanai. Tika lietota statiskā piliena tehnika - uz virsmas ar automātisku dispenseri tika uzpilināti $10 \mu \mathrm{L}$ ūdens, un piliens netika papildināts. Piliena formas izmaiņas tika fiksētas katru sekundi 30 sekundes.

Tā kā termiskā modifikācija nenodrošina koksnes imunitāti pret krāsojošām sēnēm - pelējumiem un zilējumiem, to pārklājumos ir nepieciešams lietot biocīdus. Šajā darbā tika izmantots komplekss komerciāls biocīds Wocosen TM 45, kurā aktīvās vielas ir triazola klases fungicīds propikonozols un karbamāta klases fungicīds IPBC (3-jodo2-propinil-butilkarbamāts). Lai arī šis ir brīvpieejas produkts, tas ir iekḷauts toksicitātes 2. kategorijas sarakstā, tādēl svarīgi ir lietot optimālās devas. Lai pārklājumiem izvēlētos biocīdu koncentrācijas, termiski modificētas un nemodificētas koksnes paraugi tika pārklāti ar bāzes pārklājumu, kuram bija pievienots ražotāja ieteiktā, kā arī paaugstinātas kompleksā biocīda Wocosen devas. Paraugu ar un bez virsmas pārklājumiem noturība pret pelējuma un krāsojošajām sēnēm tika noteikta saskaņā ar standartu EN 152. Paraugi, lai nodrošinātu pietiekošu mitrumu sēņu attīstībai, pirms sēņu testa uz 72 stundām ar pārklāto virsmu tika iegremdēti ūdenī. Testa kopējais ilgums -8 nedēlas, bet pirmā kontrole tika veikta pēc 6 nedẹlām. Sēṇu apaugums uz paraugu pārklātajām virsmām tika izvērtēts vizuāli pēc standarta kritērijiem (2.1. tab.).

2.1. tabula

\section{Apauguma ar koksnes krāsojošām sēnēm novērtēšanas kritēriji}

\begin{tabular}{cl}
\hline Vērtējums & \multicolumn{1}{c}{ Kritērijs } \\
\hline 0 & $0 \%$ apaugums \\
\hline 1 & viegls - viena mazāk par 10\% skarta vieta vai 10 mazi punkti \\
\hline 2 & vidējs - 10 - 25\% \\
\hline 3 & smags - 25 - 50\% \\
\hline 4 & loti smags - vairāk par 50\% \\
\hline
\end{tabular}

Paraugi ar pārklājumu ūdens caurlaidības testam tika sagatavoti saskaṇā ar standarta LVS EN 927-5 prasībām. Paraugiem $(80 \times 60 \times 20 \mathrm{~mm})$, kam pēc pārklājuma uzklāšanas pārējās skaldnes tika pārsegtas ar ūdeni necaurlaidīgu pārklājumu (ūdens caurlaidība ne lielāka par $30 \mathrm{~g}$ caur $1 \mathrm{~m}^{2}$ virsmas diennaktī). Pārklātie paraugi, kas pirms eksperimenta bija kondicionēti $\left(20 \pm 2^{\circ} \mathrm{C}\right.$, RH $\left.65 \pm 5 \%\right)$ un nosvērti ar precizitāti līdz $0.01 \mathrm{~g}$, uz $72 \mathrm{~h}$ tika ar pētāmo virsmu iemērkti destilētā ūdenī $2 \mathrm{~mm}$ dzilumā - paraugi tika novietoti uz stikla nūjiņām, un ūdens līmenis kontrolēts reizi diennaktī. Koksnes ūdens uzsūcamība tika noteikta kā masas pieaugums, attiecinot to uz virsmas laukuma vien̄̄bu $\left(\mathrm{g} \mathrm{m}^{-2}\right.$ ). Pārklājumu žūt ḷaušanas efektivitāte (pārklājumu ietekme uz žūšanas ātrumu) tika noteikta, paraugus pēc ūdens caurlaidības testa turot telpā ar kondicionētu klimatu $\left(20 \pm 2{ }^{\circ} \mathrm{C}\right.$, RH $\left.65 \pm 5 \%\right)$, regulāri nosakot masas izmaiņas un aprēķinot nenožuvušo testa laikā uzṇemtā ūdens daudzumu.

Koksnes krāsas izmaiņas pēc pārklājumu uzklāšanas tika novērtētas, spektrofotometriski nosakot atstarošanas spektrus, aprēķinot atstarošanas izmaiņu spektrus un krāsas izmaiņas $\Delta$ Eab saskaņā ar vienādojumu (2.7.). 


\subsection{Pārklātu paraugu novecināšanas testi}

Termiski modificētai koksnei ar pārklājumiem, lai novērtētu pārklājumu piemērotību un efektivitāti, tika veikti mākslīgās novecināšanas testi kamerā un āra testi, kuros paraugi atradās reālos vides apstākḷlos. Vispirms tika veikti mākslīgās novecināšanas kameras testi, jo, pateicoties tam, ka eksperimentus var veikt vienādos, kontrolētos apstākḷlos, kamera ļauj iegūt atkārtojamus rezultātus. Turklāt kamerā rezultātus var iegūt ātrāk, jo ir iespējams intensificēt procesa parametrus - nepārtraukts UV starojums, paaugstināta temperatūra, intensīva apsmidzināšana ar ūdeni, kā arī pētīt atsevišķu faktoru ietekmi uz materiālu. Tomēr kamerā var imitēt tikai daḷu no reālajiem vides faktoriem, kas iedarbojas uz koksni āra apstākḷlos. Tādēḷ, lai novērtētu termiski modificētas koksnes pasargāšanai izveidotos pārklājumus, kamerā tika novecināti paraugi ar dažādām pārklājumu sistēmām, lai atlasītu perspektīvākās pārklājumu sistēmas tālākai pārbaudei āra testā.

Mākslīgās novecināšanas testiem paraugi $(150 \times 70 \times 20 \mathrm{~mm})$ tika sagatavoti atbilstoši standartam LVS EN 927-6, un novecināšana veikta novecināšanas kamerā QLab, izmantojot fluorescentās UVA-340 tipa lampas, pilna cikla režìmā (24 h kondicionēšana pie $100 \% \mathrm{RH} 45 \pm 3{ }^{\circ} \mathrm{C}$ temperatūrā, $48 \times 2.5 \mathrm{~h}$ UV apstarošana $60 \pm 3^{\circ} \mathrm{C}$ temperatūrā un $0.5 \mathrm{~h}$ apsmidzināšana ar destilētu ūdeni) un UV režīmā (UV apstarošana $60^{\circ} \mathrm{C}$ temperatūrā). Paraugu novecošanās tika kontrolēta, ik pēc zināmiem laika periodiem apturot kameru un paraugiem spektrofotometriski nosakot atstarošanas spektrus un krāsu izmaiṇas (CIELAB krāsu modelis).

Āra testiem paraugi $(330 \times 100 \times 25 \mathrm{~mm})$ tika sagatavoti atbilstoši standarta LVS EN 927-3 prasībām. Āra testi tika veikti Rīgā (ǵeogrāfiskās koordinātas - $56^{\circ} 56$ (Z), $24^{\circ} 6$ (A)), paraugi izvietoti pret dienvidiem vērstā stendā $45^{\circ}$ leņ, ̧̧i attiecībā pret zemi (2.8. att.).

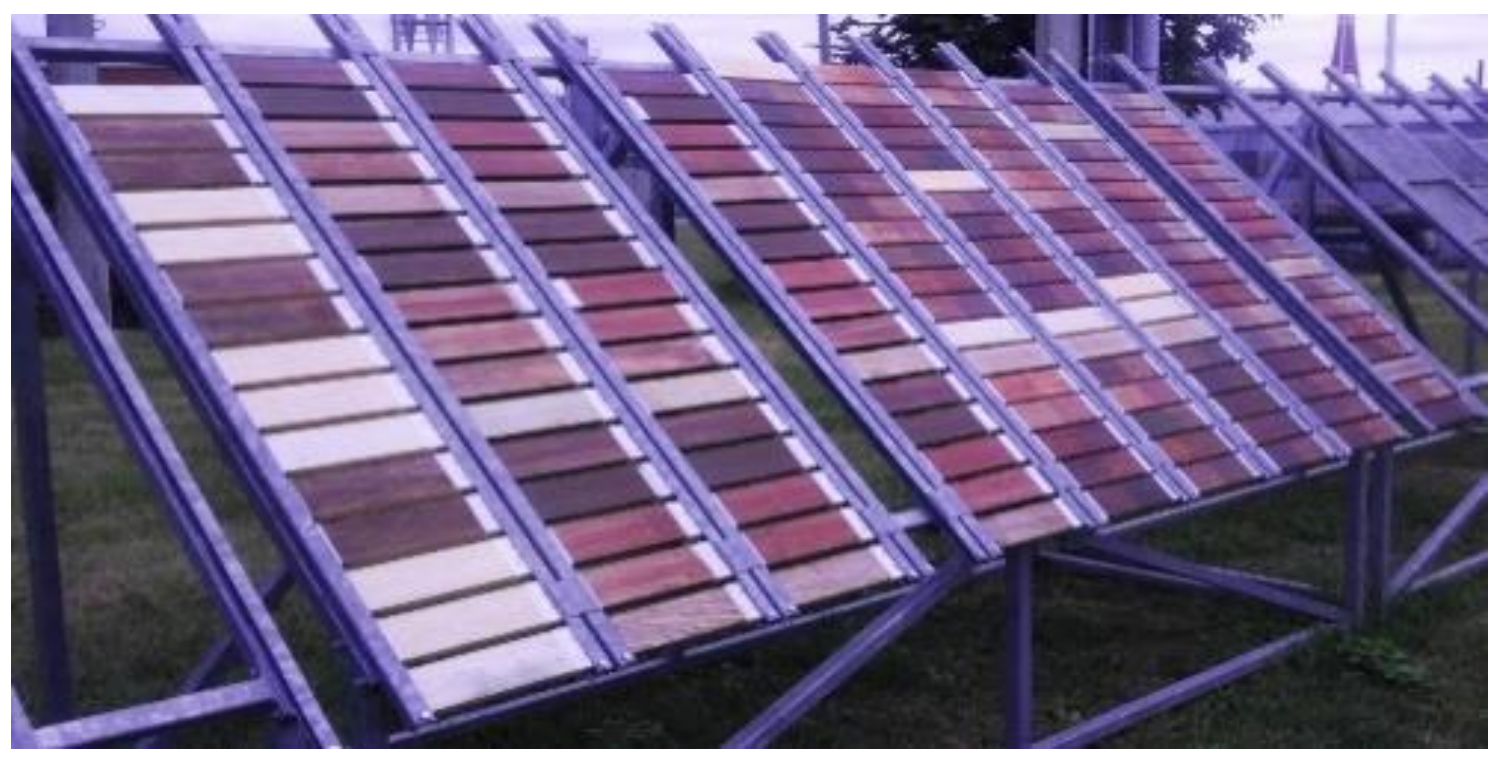

\section{8. att. Āra testa paraugu stends.}

Ik pēc zināmiem laika periodiem paraugi tika vesti uz laboratoriju, lai veiktu novecošanās kontroli. Novecošanās tika kontrolēta, paraugiem spektrofotometriski nosakot krāsas izmaiņas (CIELAB krāsu modelis), kontrolējot plaisu veidošanos un novērtējot paraugu apaugumu ar koksnes krāsojošajām sēnēm. 
Plaisu veidošanās uz paraugu virsmas tika novērtēta vizuāli. Plaisu noteikšanai tika izmantota paraugu vizuāla apskate divos līmeņos: apskatot paraugus ar neapbruṇotu aci, tika konstatētas makroplaisas, apskatot paraugus ar optisko mikroskopu МБC-1 (PSRS) pie palielinājumiem $(12.5 \times)$ un $(25 \times)$, tika novērtētas mikroplaisas. Plaisu vērtējums tika izteikts ballēs pēc 2.2. tabulā dotiem kritērijiem.

\section{Plaisu novērtējuma kritēriji}

2.2. tabula

\begin{tabular}{cl}
\hline Balles & \multicolumn{1}{c}{ Kritērijs } \\
\hline 0 & Nav saskatāmu plaisu nevienā līmen̄̄ \\
\hline 1 & Dažas pie $25 \times$ palielinājuma saskatāmas mikroplaisas \\
\hline 2 & Daudzas pie $25 \times$ palielinājuma saskatāmas mikroplaisas \\
\hline 3 & Dažas pie $12.5 \times$ palielinājuma saskatāmas mikroplaisas \\
\hline 4 & Daudzas pie $12.5 \times$ palielinājuma saskatāmas mikroplaisas \\
\hline 5 & Ar neapbruṇotu aci saskatāmas plaisas \\
\hline
\end{tabular}

Paraugu apaugums ar krāsojošām sēnēm tika noteikts vizuāli, paraugus apskatot, un paraugu apaugumu izvērtējot pēc vispārpieṇemtiem kritērijiem (2.1. tab.).

\subsection{Empīrisko datu matemātiskā apstrāde}

Empīrisko datu matemātiskai apstrādei pamatā tika izmantota aprakstošā statistika - vidējās aritmētiskās vērtības, to standartnovirzes un robežkḷūdas, kurās iekḷauta Stjūdenta sadalījuma normētā novirze pie būtiskuma līmeṇa $\alpha=0.05$. Standartnovirze, kura parāda atsevišķu mērījumu vidējo kvadrātisko novirzi no vidējās vērtības, tika aprēķināta gadījumos, kad izlases kopas apjoms bija mazāks par desmit vienībām. Lielākām izlasēm tika aprēkinātas robežkḷūdas, kas, ņemot vērā izlases apjomu, l̦auj ar pietiekoši augstu ticamību sašaurināt drošības intervālu. Izkliedes intensitāšu salīdzināšanai tika aprēķināti variācijas koeficienti, kas ir standartnovirzes relatīvā vērtība - tās attiecība pret vidējo aritmētisko, kas izteikta procentos.

Lai salīdzinātu krāsu un krāsu izmainu atškirības starp paraugkopām, tika izmantota vienfaktora dispersiju analīze (ANOVA: single factor). Par būtiskām tika pieņemtas atšķirības, kad p-vērtība ir mazāka par 0.05 (p < 0.05), kas norāda, ka ir $95 \%$ vai lielāka varbūtība, ka pastāv krāsas vai tās izmaiņu atšķirības starp analizētajām paraugu grupām.

Tā kā krāsu homogenitātes noteikšanai vienā dẹḷa plaknē tika aprēķinātas vairāk par 100 savstarpējām krāsu atšķirībām, to grafiskai attēlošanai tika izmantoti boxplot tipa grafiki (Box Plot...) jeb kastīšu diagrammas (LZA Terminoloǵijas komisijas ieteiktais termins no Akadēmiskās terminu datubāzes), kas ir standartizēts datu sadalījuma attēlošanas veids (2.9. att). 

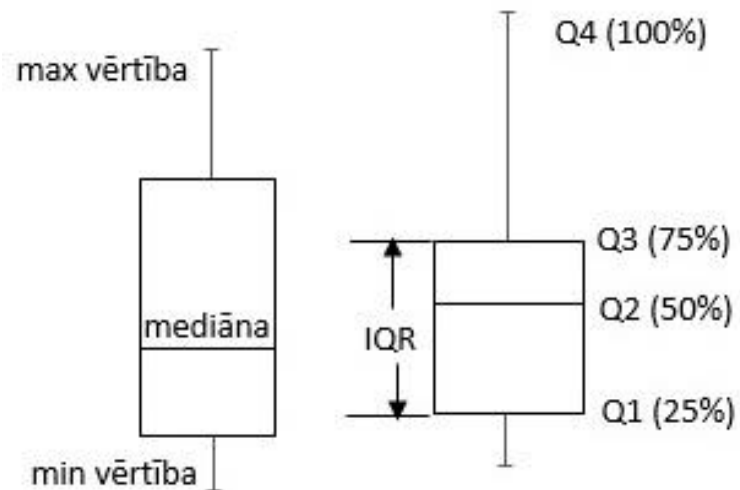

2.9. att. Datu atspoguḷošana kastī̌su diagrammu veidā.

Šajās diagrammās taisnstūra malas nosaka pirmajai un trešajai kvartilei atbilstošās vērtības, un $50 \%$ no visiem novērojumiem atrodas segmentā starp šīm vērtībām jeb starpkvartịlu apgabalā IQR (the Interquartile Range). Līnija taisnstūra iekšienē atbilst mediānai, kas ir pētāmās pazīmes vērtība, kas varianšu skaitu dala divās vienādās daḷās tā ir ranžēto vērtību viduspunkts. Nogriežņu gali uz augšu no trešās kvartiles un uz leju no pirmās kvartiles atbilst attiecīgi lielākajai (max) un zemākajai (min) datu kopas vērtîbai. Tā kā punkti, kas atrodas tālāk par $3 \times$ IQR attālumu uz vienu vai otru pusi no taisnstūra malas, tiek uzskatīti par "izlēcējiem" un tiek atzīmēti kā atsevišķi punkti, pirms grafiku veidošanas tika aprēķinātas atbilstošās robežas. Lai iegūtu kvartiļu vērtības, atsevišķu dēlu dati tika ranžēti, izmantojot datu analīzes rīku "Rank and Percentile", un aprēkinātas katrai kvartilei atbilstošās vidējās vērtības, kuras tālāk tika izmantotas grafiku izveidošanai.

Aprēķinu veikšanai un datu matemātiskajai apstrādei tika izmantota datorprogrammas Ms Exel 2010 programmu paketes Data Analysis statistikas programmas. 


\section{REZULTĀTI UN TO IZVĒRTĒJUMS}

\subsection{Termiski modificētas koksnes krāsa}

\subsubsection{Koksnes krāsas izmaiṇas termiskās modifikācijas procesā}

Ir labi zināms, ka koksne termiskās modifikācijas procesā maina savu krāsu un, atkarībā no modifikācijas apstākḷiem (temperatūras, ilguma, vides), iegūst gaišāku vai tumšāku toni. Vispār novērotā tendence ir - jo augstāka modifikācijas temperatūra, jo lielākas krāsas izmaiņas (Bekhta and Niemz, 2003; Menezzi, 2009; Mehrotra et al., 2010). Arī šajā pêtījumā izmantotās apses un baltalkšņa koksnes termiskās modifikācijas procesā būtiski mainīja krāsu, un ievērojamas krāsu izmaiņas notika, jau koksni modificējot pie relatīvi zemas temperatūras $-140^{\circ} \mathrm{C}$ (3.1. att.).
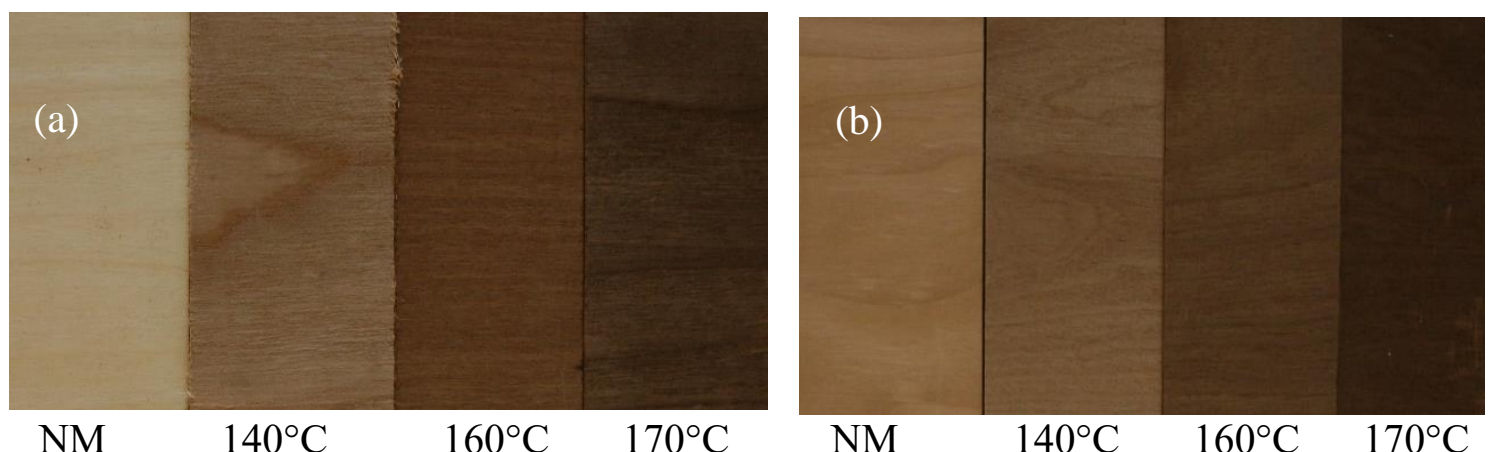

\section{1. att. Apses (a) un baltalkšṇa (b) koksne pirms un pēc modifikācijas dažādās temperatūrās.}

Apzīmējums: NM - nemodificēta koksne

Krāsas izmaiṇas ir atkarīgas ne tikai no modifikācijas apstākḷiem, bet arī no modifikācijai izmantotā materiāla - koka sugas, koksnes mitruma (Dagbro et al., 2010; Miklečić at al., 2011). Krāsas izmainuu absolūtās vērtības, kas izteiktas CIELAB krāsu modeḷa $\Delta E a b$ vienībās, apsei un baltalksnim būtiski atšḳ̄iāas, lai arī masas zudumi termiskās modifikācijas procesā abām sugām būtiski neatšḳīās ( $\mathrm{p}>0.05)$. Pie visām modifikācijas temperatūrām apses koksnes krāsa mainījās ievērojami vairāk nekā pie atbilstošām temperatūrām apstrādātas baltalkšņa koksnes krāsa (3.1. tabula).

3.1. tabula

Apses un baltalkšṇa koksnes masas zudumi un krāsas izmaiṇas $\Delta$ Eab termiskās modifikācijas procesā pie dažādām temperatūrām

\begin{tabular}{ccccc}
\hline Modifikācijas & \multicolumn{2}{c}{ Masas zudumi, \% } & \multicolumn{2}{c}{ Krāsas izmainas $\mathbf{~ E a b}$} \\
\cline { 2 - 5 } temperatūra, ${ }^{\circ} \mathbf{C}$ & Apse & Baltalksnis & Apse & Baltalksnis \\
\hline 140 & $1.2(0.3)$ & $1.1(0.3)$ & $31.5(1.1)$ & $13.6(0.6)$ \\
\hline 160 & $5.8(0.6)$ & $6.2(0.5)$ & $44.9(1.1)$ & $25.9(1.0)$ \\
\hline 170 & $12.0(1.5)$ & $11.5(1.0)$ & $50.7(0.7)$ & $29.9(0.2)$ \\
\hline
\end{tabular}

Iekavās uzrādītas robežkḷūdas ar būtiskuma līmeni $\alpha=0.05$ 
Atšķirības krāsu izmaiņu apjomā, modificējot apses un baltalkšņa koksnes, ir skaidrojamas ar to būtiski atšķirīgo dabīgo krāsu, ko pamatā nosaka fenolisko ekstraktvielu (flavonoīdi, lignāni, tannīdi, fenoli) daudzuma un sastāva atšķirības, jo tieši tās ir koksnes krāsu nosakošie ḳīmiskie komponenti (Hon and Minemura, 2000; Temiz et al., 2005). N̦emot vērā, ka objekta krāsa veidojas no tā atstaroto viḷnu kopuma redzamās gaismas diapazonā, uzskatāmi gan krāsas, gan krāsas izmaiņu raksturu parāda atstarošanas spektri. 3.2. attēlā doti abu šajā darbā izmantoto koku sugu atstarošanas spektri kā pirms, tā pēc termiskās modifikācijas dažādās temperatūrās. Redzams, ka nemodificētas apses un baltalkšņa koksnes atstarošanas spektri ievērojami atšķiras. Toties termiskās modifikācijas rezultātā atšķirības starp abu sugu koksnēm raksturīgajiem atstarošanas spektriem samazinās, spektri kḷūst līdzīgāki, un pēc modifikācijas pie $170^{\circ} \mathrm{C}$ atstarošanas atšķirības starp sugām ir gandrīz izzudušas. No 3.2. attēla skaidri redzams, ka apsei atstarošanas izmaiņas, koksni termiski modificējot, ir daudz lielākas, kas arī atspoguḷojas lielākās krāsu izmaiṇu vērtībās $\Delta$ Eab. Aprēķinot vidējās krāsu atškirīibas starp apses un baltalkšṇa koksnēm pēc modifikācijas pie $170^{\circ} \mathrm{C}$, tās ir $1.7 \pm 0.3 \Delta \mathrm{Eab}$ vienības.

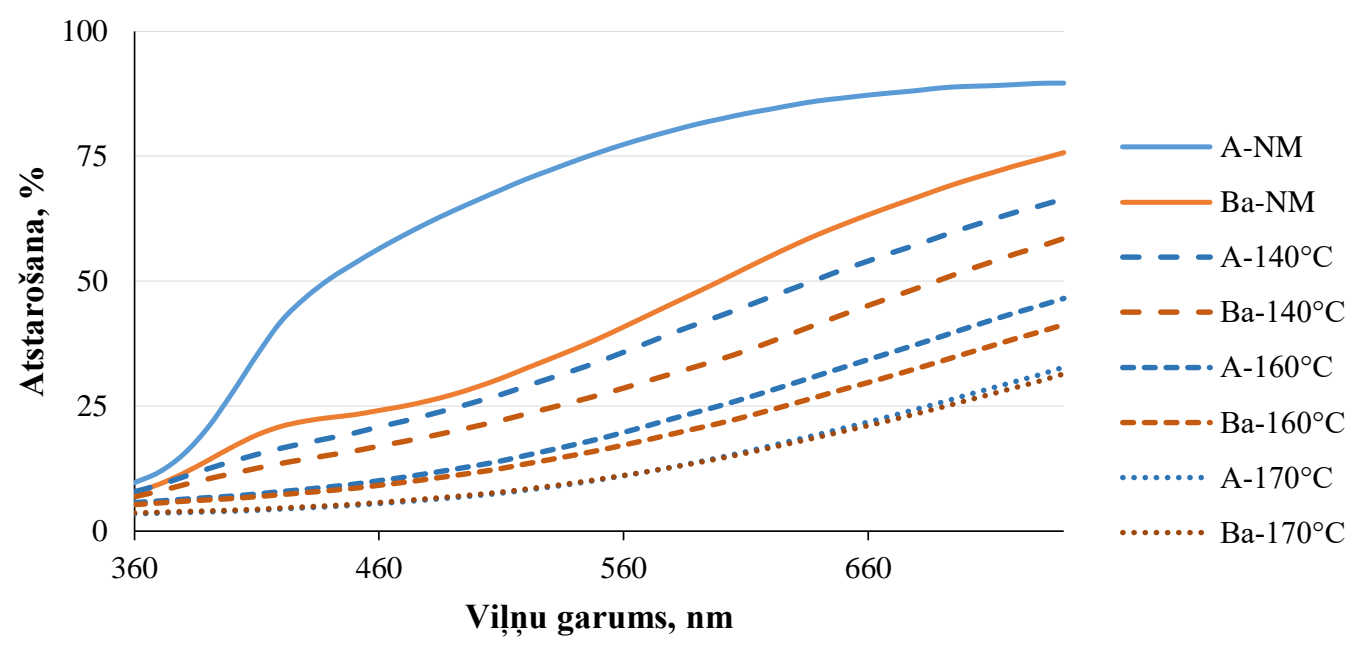

\section{2. att. Nemodificētas (NM) un dažādās temperatūrās modificētas apses un} baltalkšṇa koksnes atstarošanas spektri redzamās gaismas viḷnu apgabalā. Apzīmējumi: A - apse; Ba - baltalksnis.

Krāsas atškirīibu izzušana starp termiski modificētām koksnēm, neskatoties uz to sākotnējo, ar ekstraktvielām saistīto, atšķirīgo krāsu norāda, ka termiski modificētas koksnes krāsu nosakošo hromoforo grupu veidošanās galvenokārt ir saistīta ar tās ḳīmiskā sastāva pamatkomponentiem, kas abām kā lapkoku koksnēm ir līdzīgi. Pētījumos ir konstatēts, ka arī koksnēm ar pēc krāsas atšķirīgu kodolu un aplievu, termiskās modifikācijas rezultātā koksnes krāsa kḷūst homogēna (Bächle et al., 2007; Cirule and Kuka, 2015). Visi šie rezultāti norāda, ka modificētas koksnes krāsas izcelsme galvenokārt ir saistīta ar tās ķīmiskajiem pamatkomponentiem, un nevis ekstraktvielām, kuras var būtiski atšķirties.

Lai noteiktu, vai termiski modificētas koksnes raksturīgo krāsu nosakošās hromoforās grupas ir saistītas ar mazmolekulāriem koksnes termiskās degradācijas produktiem, vai koksnes pamatkomponentiem, termiski modificēta koksne tika 
ekstraǵēta ar ūdeni un acetonu. Salīdzinot ekstraǵētas un neekstraǵētas koksnes krāsu, tika noteiktas koksnes krāsu izmaiņas ekstrakcijas rezultātā. Eksperimentā tika izmantota pie $170^{\circ} \mathrm{C}$ grādiem modificēta apses koksne, kurai termiskās modifikācijas izraisītās krāsu izmaiņas bija vislielākās. No termiski modificētas koksnes ar ūdeni ekstraǵējās 6.7 \% ekstraktvielu, ar acetonu - $11.3 \%$. Lai arī abos gadījumos ekstraktu šķ̄īumi bija intensīvi iekrāsojušies, tomēr koksnes krāsa pēc ekstrakcijas tikpat kā nebija mainījusies (3.3. att.). Arī $\Delta$ Eab vienībās aprēķinātās koksnes krāsas izmaiṇas ar ūdeni ekstraǵētai koksnei bija $1.0 \pm 0.2$ vienības, ar acetonu ekstraǵētai koksnei $-2.1 \pm 0.2$ vienības.

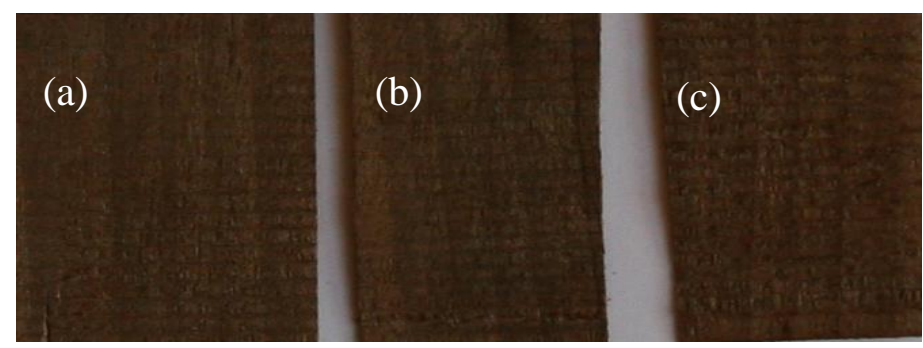

\section{3. att. Termiski modificēta $\left(\mathbf{1 7 0}^{\circ} \mathrm{C}\right)$ apses koksne pirms (a), pēc ekstrakcijas ar ūdeni (b) un pēc ekstrakcija ar acetonu (c).}

Intensīvā ekstraktu krāsojuma iemesls varētu būt dažu savienojumu spēja veidot intensīvu krāsu pie ḷoti zemas koncentrācijas, kā tas ir konstatēts, piemēram, ar hinona tipa savienojumiem, kas veidojas koksnes novecošanās procesā (Tolvaj and Faix, 1995).

To, ka nav būtiskas krāsu atšķirības starp ekstraǵētajām un neekstarǵētu koksni, apstiprina to atstarošanas spektri, kas gandrīz sakrīt, un ir tikai nelielas atšḳirības redzamās gaismas spektra pašu garāko viḷnu apgabalā (3.4. att.). Tas viss norāda, ka termiski modificētai koksnei tās raksturīgo krāsu nosakošās hromoforās grupas nav saistītas ar mazmolekulāriem, viegli ekstraǵējamiem savienojumiem, bet pamatā ir lielmolekulāru savienojumu sastāvā.

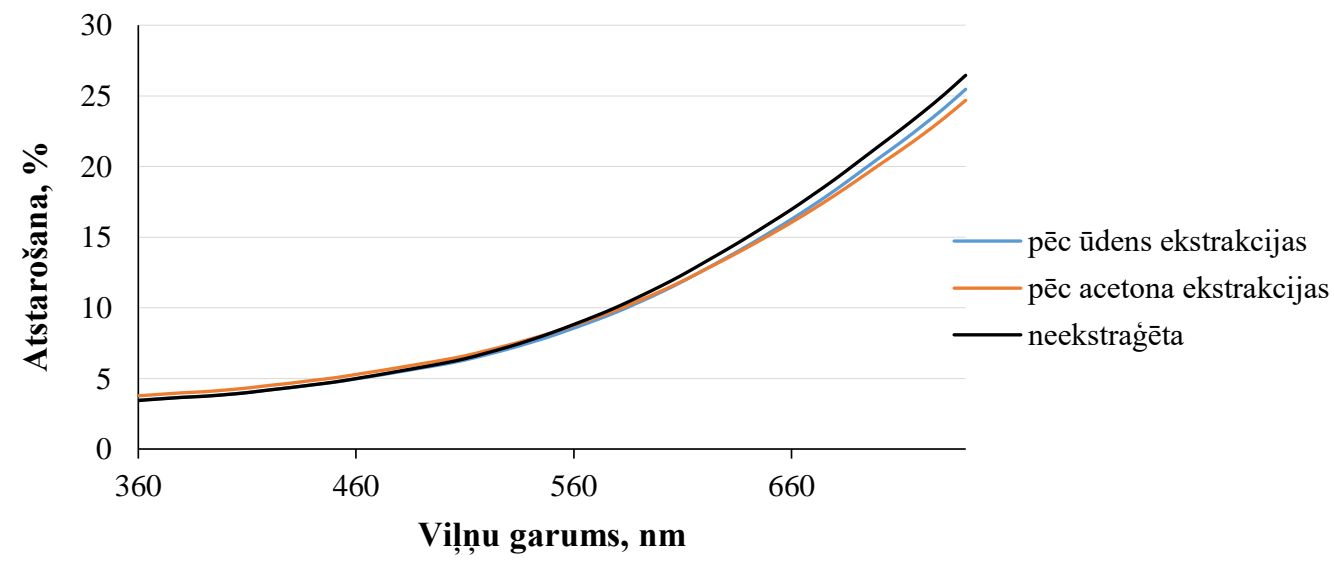

3.4. att. Neekstraǵētas un ar ūdeni un acetonu ekstraǵētas termiski modificētas $\left(170^{\circ} \mathrm{C}\right)$ apses koksnes atstarošanas spektri. 
Arī ekstraktu UV-redzamās gaismas apgabalu spektri, kuri ir normalizēti attiecībā pret augstāko absorbcijas vērtību, pieņemot to kā vienu vienību lielu absorbciju, parāda, ka gan ar ūdeni, gan acetonu ekstraǵêtās vielas galvenokārt absorbē starojumu spektra UV apgabalā un pavisam nedaudz viḷnu apgabalā virs $400 \mathrm{~nm}$ (3.5. att.).

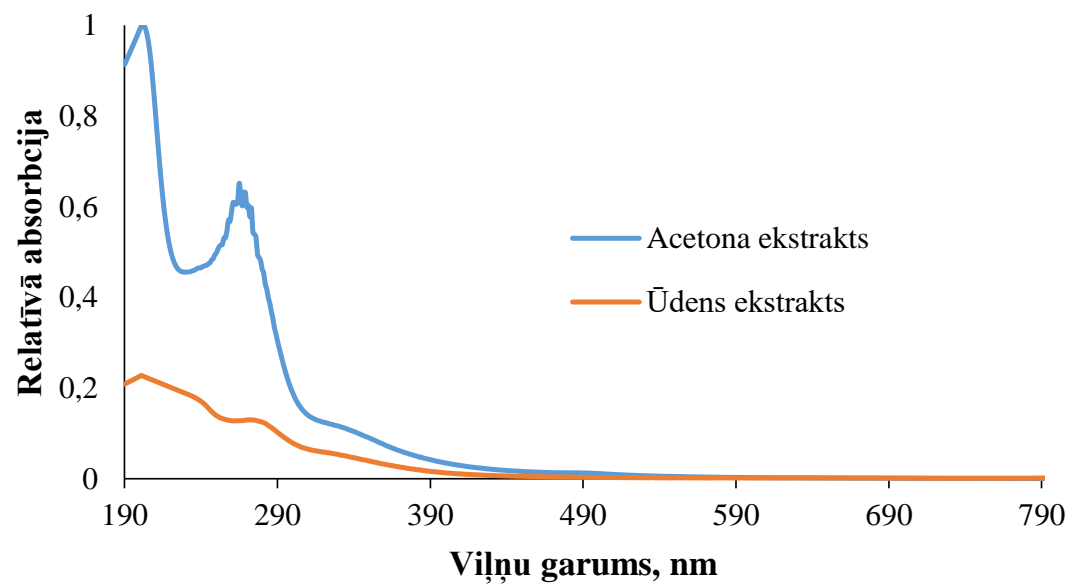

\section{5. att. Termiski modificētas $\left(170^{\circ} \mathrm{C}\right)$ apses koksnes ūdens un acetona ekstraktu spektri UV-redzamās gaismas apgabalā.}

Līdzīgi rezultāti ir iegūti arī pêtījumā par priedes un dižskābarža termisko modifikāciju, kurā koksnes ekstraktu būtiska absorbcijas redzamās gaismas viļ̧nu apgabalā tika novērota tikai pie modifikācijas temperatūrām virs $200^{\circ} \mathrm{C}$ (Ahajji et al., 2009).

Ir noskaidrots, ka nemodificētas koksnes ekstraktvielas, darbojoties kā antioksidanti, aizkavē tās fotodegradāciju (Nzokou and Kamdem, 2006). Pēc neekstrag̣ētas un ekstraǵētas termiski modificētas $\left(170^{\circ} \mathrm{C}\right)$ apses koksnes 100 stundu ekspozīcijas saulē tika novērots, ka, lai arī atškirīibas nebija statistiski būtiskas ( $p>0.05)$, tomēr mazākas krāsas izmaiṇas bija neekstraǵētai koksnei.

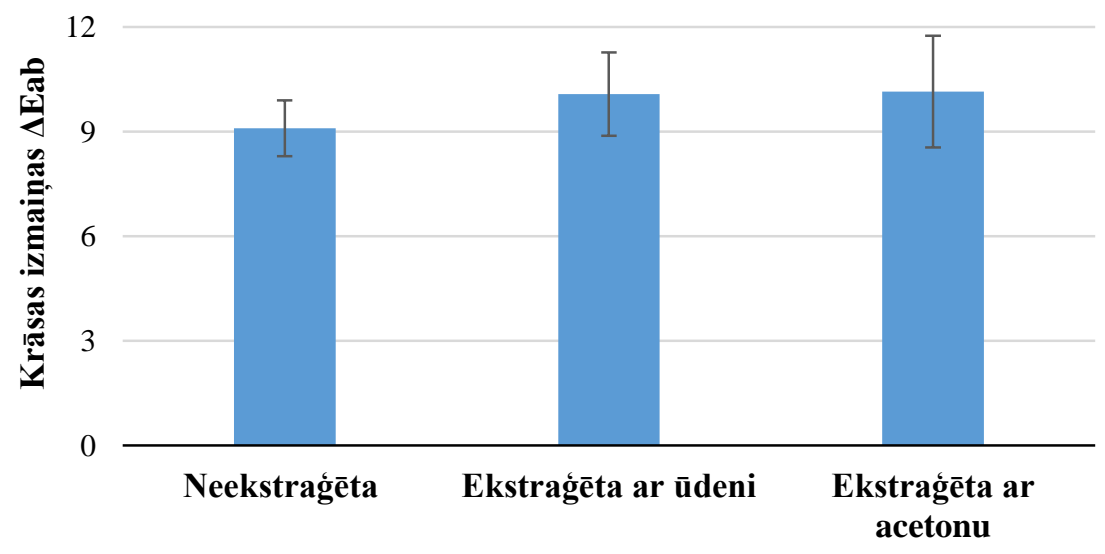

3.6. att. Neekstrageètas un ekstrag̀ètas termiski modificētas $\left(1^{\circ}{ }^{\circ} \mathrm{C}\right)$ apses koksnes krāsas izmainas $\Delta$ Eab ( \pm standartnovirze) pēc 100 stundu ekspozīcijas saulē. 
Tas varētu liecināt, ka arī termiski modificētas koksnes ekstraktvielas, intensīvi absorbējot UV starojumu, daḷēji pasargā koksni no saules starojuma ierosinātiem procesiem.

Krāsas veidošanās procesam termiskās modifikācijas rezultātā l,auj izsekot atstarošanas izmaiṇu spektri, kuri tiek iegūti, atṇemot sākotnējā spektra atstarošanas vērtības pie attiecīgajiem viḷnu garumiem no rezultējošā spektra attiecīgajām vērtībām. Atstarošanas izmaiṇu spektri parāda, kā atstarošana izmainās pie konkrētiem viļ̣nu garumiem (3.7. att.).

(a)

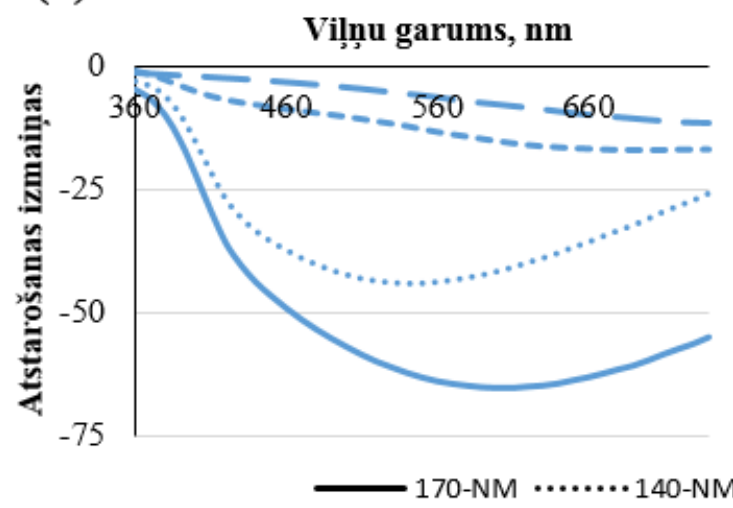

(b)

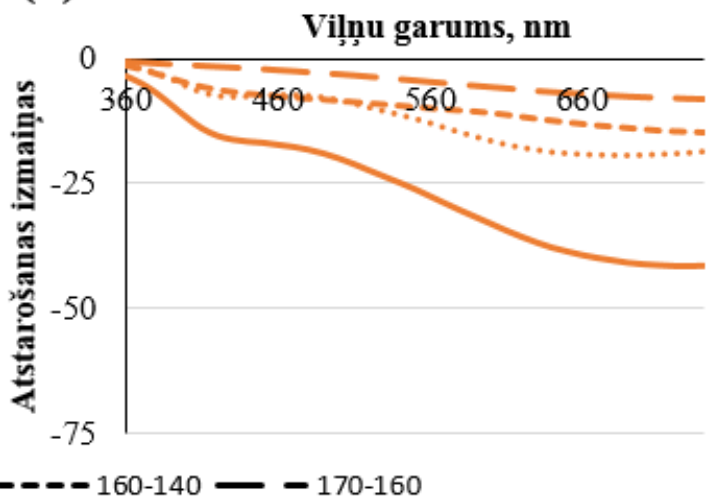

\section{7. att. Apses (a) un baltalkšṇa (b) koksnes atstarošanas izmaiṇu spektri redzamās} gaismas diapazonā termiskās modifikācijas rezultātā.

(170-NM) izmainas starp nemodificētu un pie $170^{\circ} \mathrm{C}$ modificētu koksni; (140-NM) izmainas koksni modificējot līdz $140^{\circ} \mathrm{C} ;(160-140)$ izmainas koksni modificējot no $140^{\circ} \mathrm{C}$ līdz $160^{\circ} \mathrm{C}$; izmainas koksni modificējot no $160^{\circ} \mathrm{C}$ līdz $170^{\circ} \mathrm{C}$.

Atstarošana termiskās modifikācijas rezultātā samazinās visā redzamās gaismas spektra apgabalā, kas norāda, ka modifikācijas procesā veidojas dažādas hromoforās grupas ar raksturīgu absorbciju visā redzamās gaismas viḷnu apgabalā. Jau pie relatīvi zemas modifikācijas temperatūras $\left(140^{\circ} \mathrm{C}\right)$ koksnei vērojamas ievērojamas atstarošanas izmaiņas, kas atspoguḷojas arī krāsu izmaiṇu lielumā (3.1. tab.). Īpaši lielas izmaiṇas šai temperatūru intervālā ir apses koksnei, kam raksturīgs izteikts atstarošanas samazinājuma maksimumu ap $550 \mathrm{~nm}$. Modifikācijas temperatūru paaugstinot virs $140^{\circ} \mathrm{C}$, abām pētījumā izmantotajām koku sugām atstarošanas izmaiṇu tendences ir līdzịgas - lielāks atstarošanas samazinājums ir tieši garāko viḷnu apgabalā. Paaugstinot modifikācijas temperatūru no $160^{\circ} \mathrm{C}$ līdz $170^{\circ} \mathrm{C}$, atstarošanas izmaiņas ir salīdzinoši nelielas visā spektra apgabalā. Salīdzinot atstarošanas izmaiņu raksturu temperatūru intervālos $\left(140^{\circ} \mathrm{C}\right.$ $\left.-160^{\circ} \mathrm{C}\right)$ un $\left(160^{\circ} \mathrm{C}-170^{\circ} \mathrm{C}\right)$, skaidri redzama tendence, ka abos temperatūru intervālos atstarošanas izmaiņas nav proporcionāli vienādas visā spektra apgabalā (3.8. att.). 


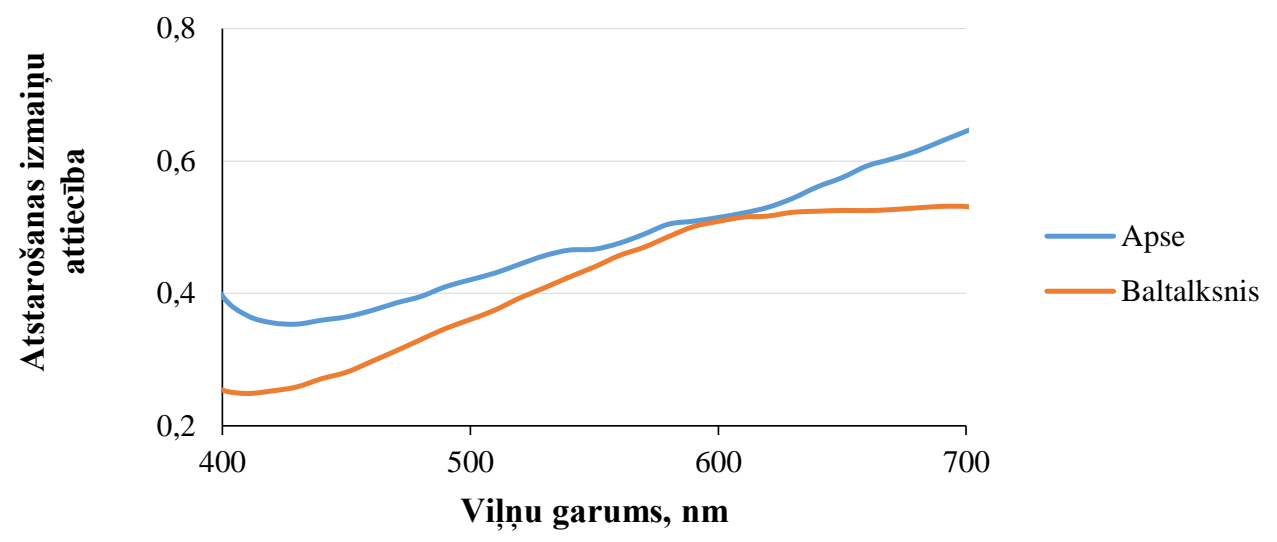

\section{8. att. Termiski modificētas apses un baltalkšṇa koksnes atstarošanas izmaiṇu attiecība modifikācijas temperatūru intervāliem $\left(160^{\circ} \mathrm{C}-170^{\circ} \mathrm{C}\right)$ pret $\left(140^{\circ} \mathrm{C}-160^{\circ} \mathrm{C}\right)$.}

Salīdzinot ar izmaiņām temperatūru intervālā $\left(140^{\circ} \mathrm{C}-160^{\circ} \mathrm{C}\right)$, atstarošanas izmaiņas temperatūru intervālā $\left(160^{\circ} \mathrm{C}-170^{\circ} \mathrm{C}\right)$ ir mazākas visā redzamās gaismas spektra apgabalā - atstarošanas izmaiṇu attiecība mazāka par viens pie visiem viḷnu garumiem. Tomēr relatīvās izmaiņas garāko viḷnu apgabalā ir pat divas reizes lielākas nekā īsāko viḷnu apgabalā. Šie rezultāti parāda, ka modificētas koksnes krāsu nosakošie savienojumi, atkarībā no modifikācijas intensitātes, mainās ne tikai kvantitatīvi, akumulējoties un pieaugot to kopējam daudzumam, bet izmainās arī kvalitatīvais sastāvs. Palielinoties modifikācijas temperatūrai, koksnē palielinās garākos viḷnus absorbējošu hromoforo grupu īpatsvars. Tam varētu būt nozīme koksnes un saules starojuma mijiedarbībā, jo palielinās koksnes spēja absorbēt saules starojuma daḷu, kam, lai arī raksturīga relatīvi zema fotonu enerğija, toties augsta kopējā starojuma intensitāte, kas potenciāli, bet ne obligāti var izraisīt fotodegradācijas procesus (Hon and Minemura, 2000). Novērojumu, ka dažādās modifikācijas temperatūrās koksnes krāsas izmaiṇu raksturs atšķiras, varētu skaidrot ar izteikto hipotēzi par dominējošo krāsas izmaiṇu saistību ar atšķirīgu koksnes ķīmisko komponentu pārvērtībām dažādās modifikācijas temperatūrās (González-Peña and Hale, 2009a).

\subsubsection{Termiski modificētas koksnes krāsas homogenitāte}

Koksnes kā dekoratīva materiāla svarīga īpašība ir tās krāsas homogenitāte. Šī darba ietvaros tika noteiktas un analizētas koksnes krāsas atšķirības starp termiski modificētiem dēḷiem, dēḷa vienā plaknē, kā arī dažādos dēḷa dziḷumos.

Atkarībā no sugas nemodificētas koksnes krāsa var variēt diezgan plašās robežās, un krāsu atškiirības divu līdz trīs $\Delta$ Eab vienību robežās tiek uzskatītas par pieņemamām (Buchelt and Wagenführ, 2012). Koksnes krāsas homogenitāte starp dēliem tika salīdzināta, katra atsevišķa dēḷa krāsas raksturošanai izmantojot vidējos dēḷa krāsu parametrus un aprēḳinot starpības starp tiem. Koksnes krāsas atškikīību analīze parādīja, ka termiskās modifikācijas rezultātā gan apses, gan baltalkšṇa krāsa, salīdzinot starp dẹliem, kḷūst viendabīgāka (3.9. att.). 
(a)

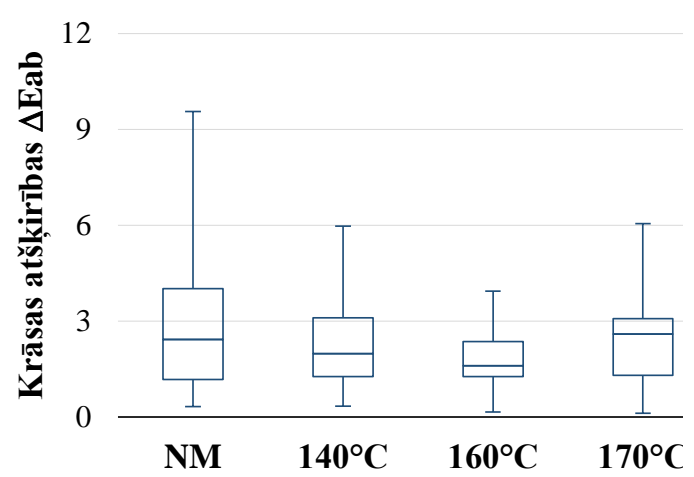

(b)

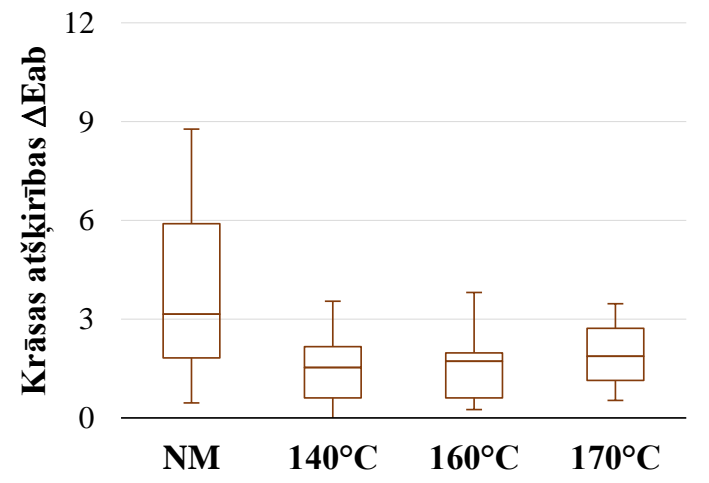

\section{9. att. Nemodificētas (NM) un pie dažādām temperatūrām modificētas apses (a) un baltalkšṇa (b) koksnes krāsu atšḳirības $\Delta$ Eab starp dēḷiem.}

Kā redzams, modificētajai koksnei pie visām modifikācijas temperatūrām 75\% gadījumu ("kastîtes" augšējā mala) atšķirības ir zem trīs $\Delta$ Eab vienībām. Arī maksimālās krāsu atšķirības starp dēliem termiski modificētai koksnei ir ievērojami zemākas nekā nemodificētai koksnei. Īpaši zemas maksimālās krāsu atšķirības starp dēliem ir termiski modificētai baltalkšņa koksnei, kam tās nepārsniedz četras $\Delta$ Eab vienības nevienam modifikācijas režīmam. Visi analizētie temperatūras režīmi nodrošina līdzīgu koksnes krāsas homogenitāti starp dēliem. Termiski modificētas koksnes krāsas homogenitāte nav plaši pētīta un analizēta, bet publicētie rezultāti liecina, ka arī citos pētījumos ir novērota krāsu atšķirību samazināšanās starp dẹliem pēc to termiskās modifikācijas (Schnabel et al., 2007; Arnold, 2012).

Otrs līmenis, kādā tika salīdzināta nemodificētas un modificētas koksnes krāsas homogenitāte, bija starp atsevišķiem punktiem dēḷa vienā plaknē (3.10. att.).

(a)

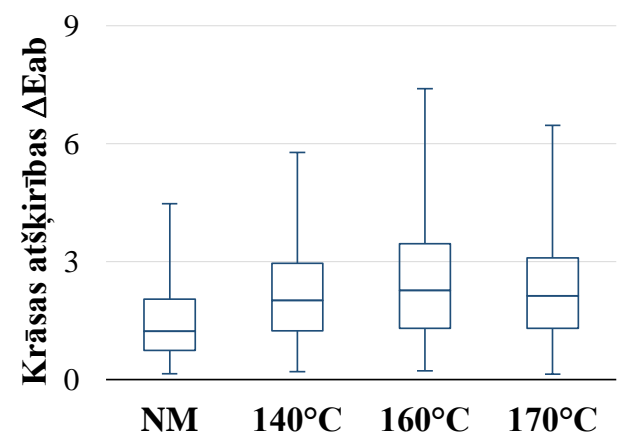

(b)

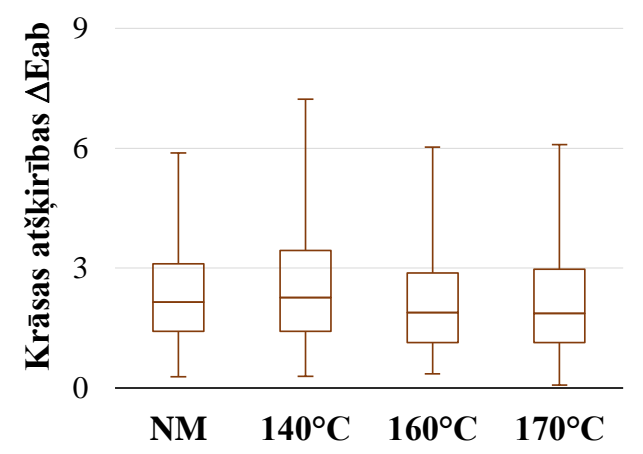

\subsection{0. att. Nemodificētas (NM) un termiski modificētas apses (a) un baltalkšṇa (b)} koksnes krāsas atšḳirības $\Delta$ Eab vienā dēḷa plaknē. 
Salīdzinot 3.9. un 3.10. attēlus, var redzēt, ka abu sugu nemodificētai koksnei krāsu atšḳirības starp punktiem dēḷa vienā plaknē ir ievērojami mazākas par atšķirībām starp dēlu vidējām krāsām. Baltalksnim modifikācijas rezultātā dēḷa plaknes krāsas homogenitāte daudz nemainās. Toties termiski modificētai apsei krāsas atšķirības starp dēla plaknes punktiem ir ievērojami lielākas nekā nemodificētai koksnei. Tomēr abām sugām, lai arī aptuveni $25 \%$ aprēḳināto atšķirību atrodas virs trīs $\Delta$ Eab vienībām, vidējās krāsas atšķirību vērtības pie visām analizētajām temperatūrām modificētai koksnei ir mazākas par trīs vienībām.

Termiski modificētas koksnes krāsas analīze dēlī dažādos attālumos (dziḷumos) no tā virsmas parādīja, ka abām sugām pie visām modifikācijas temperatūrām dēḷa virsmas krāsa ievērojami atšķiras no koksnes krāsas dziḷākos slāņos (3.11. att.).

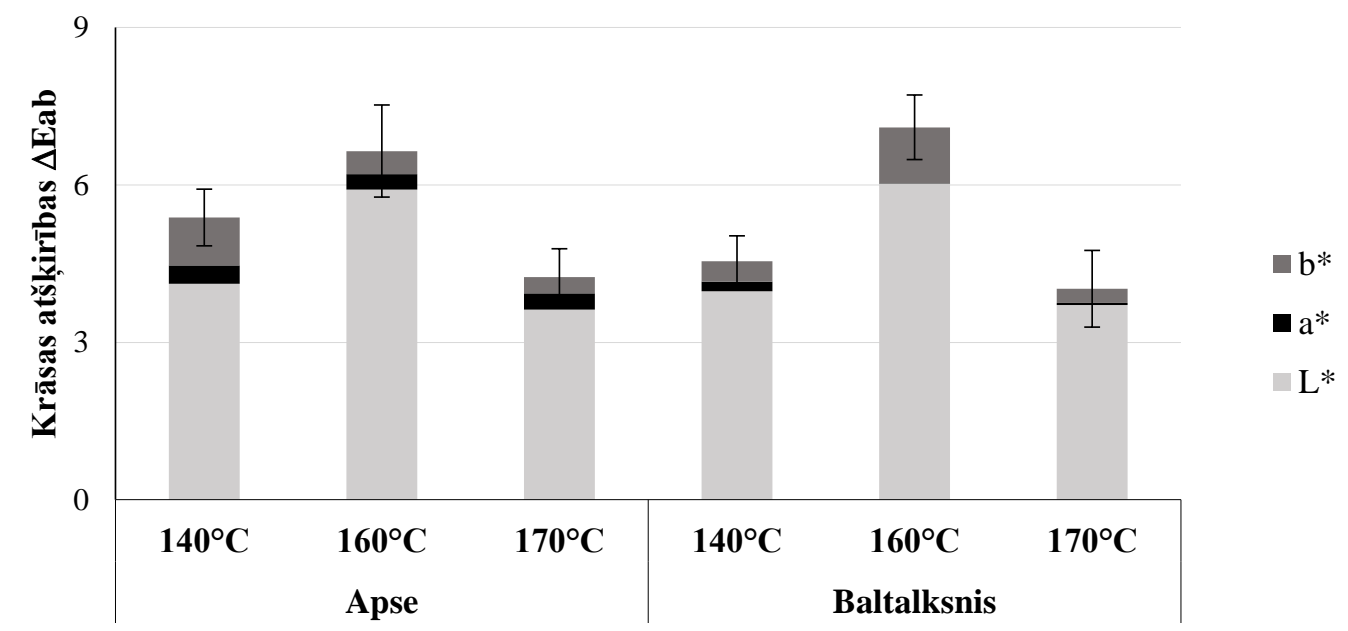

\subsection{1. att. Termiski modificētas apses un baltalkšņa koksnes vidējās krāsu atšķirības $\Delta$ Eab ( \pm robežkḷūda; $\alpha=0.05$ ) starp dēḷa virsslāni un dzilāakajiem slāṇiem, parādot katra krāsu parametra īpatsvaru kopējās atšķirībās.}

Par trim $\Delta$ Eab vienībām lielākas vērtības norāda, ka visos aplūkotajos gadījumos starp dēḷa virsmu un dziḷākiem slāņiem ir ar aci skaidri saskatāmas krāsu atšķirīibas. Tomēr šajā pētījumā novērotās krāsu atšķirības bija daudz mazākas par atšķirīibām, kādas tika konstatētas starp dēla virsmu un centrālo daḷu, koksni modificējot eḷlas vidē, kad vidējās krāsu atšķirības pārsniedza $15 \Delta$ Eab vienības (Dubey et. al., 2011). Apsei un baltalksnim krāsu atšķirību raksturs starp dēḷa virsmu un dziḷākajiem slāņiem ir līdzīgs, kā to parāda atstarošanas atškikirību spektri (3.12. att.). 

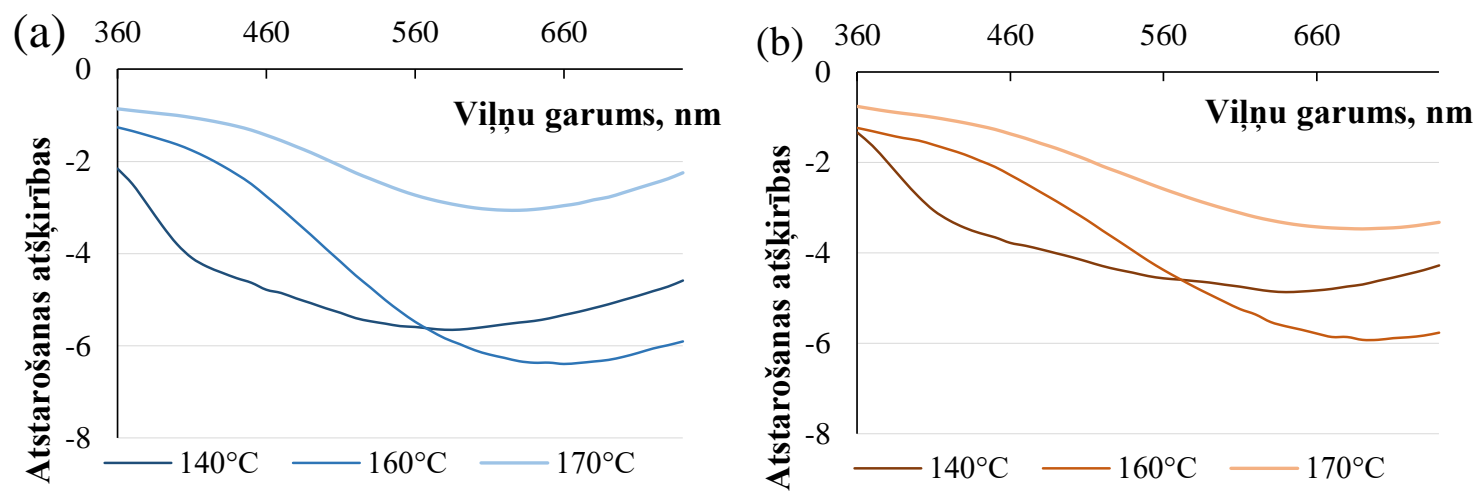

\subsection{2. att. Atstarošanas spektru atšķirības starp termiski modificētu apses (a) un baltalkšṇa (b) dēḷu virskārtu un dziḷākajiem slāṇiem.}

Visos gadījumos dēḷa virsslānim raksturīga mazāka atstarošana visā redzamās gaismas viḷnu apgabalā, bet proporcionālais atstarošanas samazinājums pa viḷnu garumiem atšksiras dažādās temperatūrās modificētiem dēliem. Pie $160^{\circ} \mathrm{C}$ un $170^{\circ} \mathrm{C}$ modificētiem dēliem krāsu atšḳirību starp dẹla virsslāni un dziḷākiem slāņiem rada galvenokārt virsslāņa lielāks atstarošanas samazinājums garāko viḷnu apgabalā. $140^{\circ} \mathrm{C}$ modificētu dēlu atstarošanas atškirīibās salīdzinoši lielāks īpatsvars ir atšķirībām spektra īsāko un vidējo viļ̧̣u apgabalā. Kopējo atstarošanas atšķirību apjomu var aprēķināt nosacītās vienībās kā laukumu virs atstarošanas atšķirību spektru līnijām. Šis atstarošanas atšķirīibu apjoms starp virsslāni un dziḷākiem slāņiem ir līdzīgs pie $140^{\circ} \mathrm{C}$ un $160^{\circ} \mathrm{C}$ modificētai koksnei, bet ievērojami mazākas atstarošanas atšķirības ir pie $170^{\circ} \mathrm{C}$ modificētiem dēliem (3.2.tabula).

3.2. tabula

Termiski modificētu apses un baltalkšṇa dẹḷu summārās atstarošanas spektru atšḳirības starp dēḷ virsējo un dziḷākajiem slāṇiem, nosacītās vienības

\begin{tabular}{ccc}
\hline Modifikācijas temperatūra $\left({ }^{\circ} \mathbf{C}\right)$ & Apse & Baltalksnis \\
\hline 140 & $189(17)$ & $157(12)$ \\
\hline 160 & $174(18)$ & $152(10)$ \\
\hline 170 & $84(6)$ & $90(7)$ \\
\hline
\end{tabular}

Iekavās uzrādītas robežkḷūdas ar būtiskuma līmeni $\alpha=0.05$

Tas ir pretrunā ar krāsu atšķirību $\Delta$ Eab vērtībām (3.11. att.). Š $\overline{1}$ nesakritība ir saistīta ar to, ka CIELAB krāsu modelis imitē cilvēka krāsu uztveri, bet cilvēka acs jutība dažādos redzamās gaismas spektra apgabalos ir atšķirīga. Tādēl $\Delta$ Eab vērtības ir atkarīgas ne tikai no kopējām atstarošana atšķirībām, bet arī no cilvēka redzes jutības katrā viḷnu apgabalā, kā rezultātā atstarošanas atšķirībām dažādos spektra apgabalos nav vienāds īpatsvars aprēḳinātajās kopējās krāsu atškiirībās $\Delta \mathrm{Eab}$ (Pauler, 2002).

Kā redzams 3.11. attēlā, krāsu atšķirīibas $\Delta$ Eab starp dēḷa virsējo un dziḷākajiem slāņiem galvenokārt veido gaišuma parametra $L^{*}$ atšķirības, un to īpatsvars kopējās krāsu 
atšķirīibās visos gadījumos ir lielāks par $80 \%$. Tādēḷ gaišuma parametru L* var izmantot, lai attēlotu krāsu izmaiṇu raksturu pa visiem pētītajiem dēḷa slāṇiem (3.13. att.).

(a)

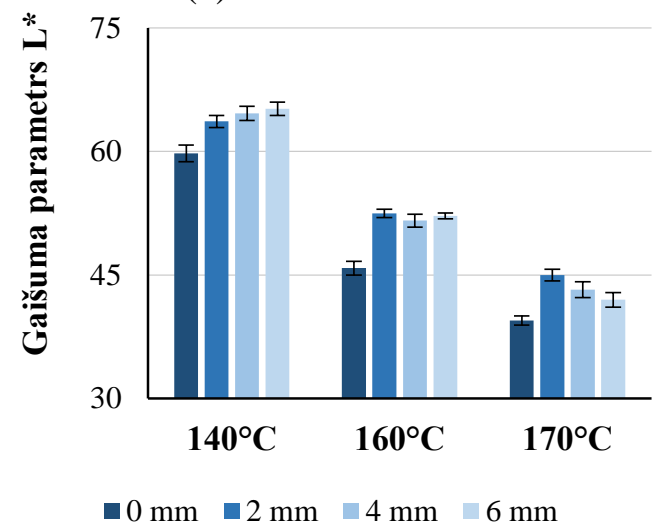

(b)

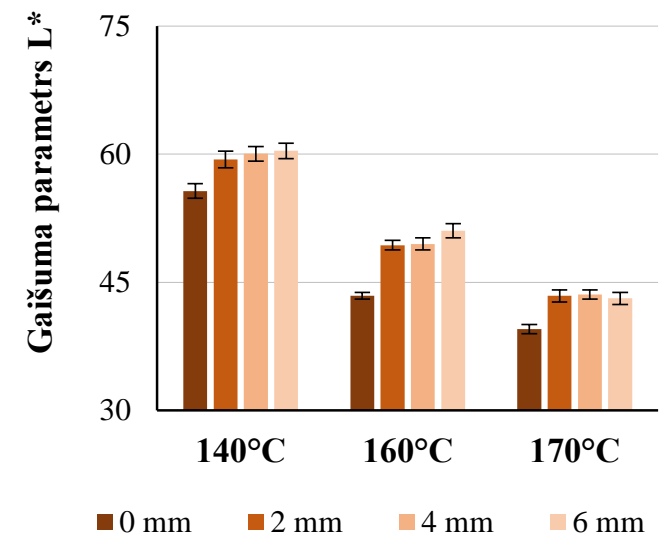

3.13.att. Gaišuma parametra $L$ * vērtības ( \pm robežkḷūda; $\alpha=0.05)$ termiski modificētu apses (a) un baltalkšṇa (b) dēḷu slāṇiem dažādos attālumos no virsmas.

Pie visām modifikācijas temperatūrām dēḷa virsslānis $(0 \mathrm{~mm})$ ir būtiski tumšāks par dziḷākajiem slāṇiem. Gaišuma parametra izmaiņu raksturs pārējos slāṇos ir līdzīgs pie modifikācijas temperatūrām $140^{\circ} \mathrm{C}$ un $160^{\circ} \mathrm{C}$, taču atškirīgs pie $170^{\circ} \mathrm{C}$. Pie zemākajām modifikācijas temperatūrām gaišuma parametra vērtība pieauga virzienā no dēḷa virsmas uz centru, un gaišākā koksne, kas salīdzinoši mazāk ir mainījusies modifikācijas procesā, atrodas dēḷa centrālajā daļā. Savukārt pie $170^{\circ} \mathrm{C}$ modificētiem dēliem gaišākā koksne ir tieši slānī zem relatīvi tumšā virsslāņa, un nākošajos slāņos centra virzienā gaišuma parametra vērtības atkal samazinās. Baltalkšņa gadījumā, aprēķinot vidējās vērtības, šī tendence vairs nav saskatāma, bet tā tika novērota pilnīgi visiem analizētajiem dēliem abām pētītajām sugām. Viens no skaidrojumiem varētu būt, ka šajā modifikācijas režīmā, kurā koksne ne tikai tiek pakḷauta augstākai temperatūrai, bet, ņemot vērā laiku, kas nepieciešams temperatūras pacelšanai un atdzesēšanai, arī ilgākam kopējam modifikācijas procesam, koksnes termiskās degradācijas laikā notiekošo eksotermisko reakciju rezultātā dẹlu vidū temperatūra uz pietiekoši ilgu laiku paceḷas augstāka un koksne dēla centrā tiek pakḷauta intensīvākai modifikācijai (Johansson and Morén, 2006; Turner et al., 2010).

Salīdzinot koksnes krāsu starp dēlu dziḷākajiem slāṇiem $(2 \mathrm{~mm}, 4$ mm un 6 mm no virsmas), abām sugām pie visām modifikācijas temperatūrām krāsu atšķirības ir nelielas un tikai $170^{\circ} \mathrm{C}$ modificētai apsei pārsniedza divas $\Delta \mathrm{Eab}$ vienības. (3.14. att.). 


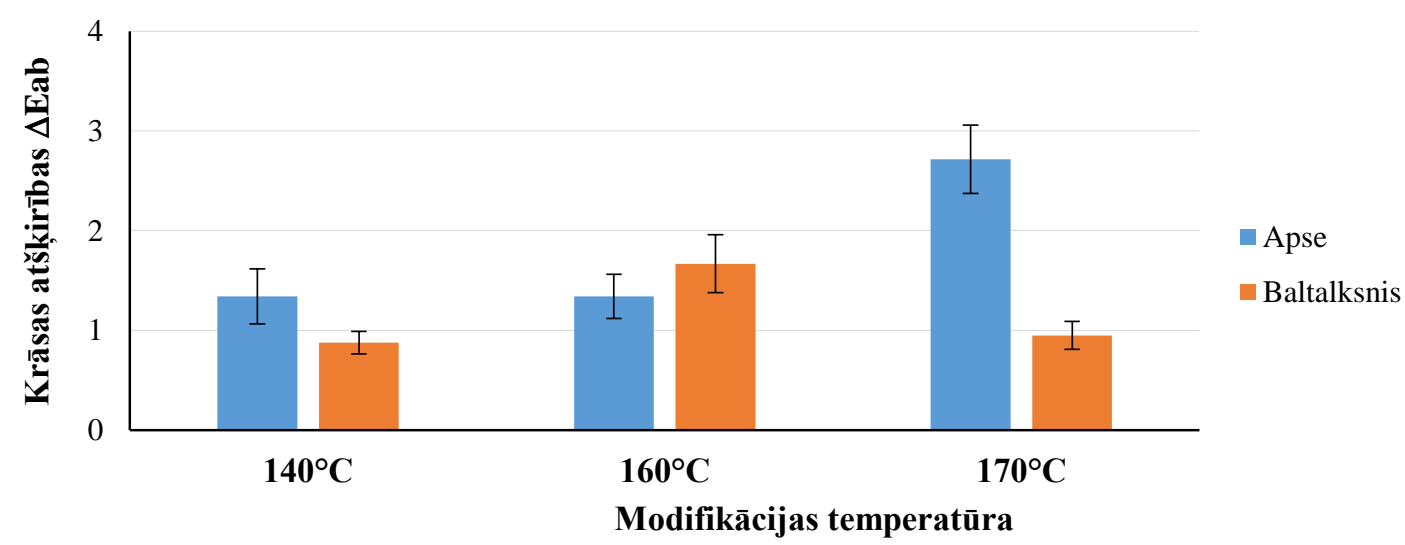

\subsection{4. att. Termiski modificētas apses un baltalkšṇa koksnes krāsas vidējās atšḳirības $\Delta$ Eab ( \pm robežkḷūda; $\alpha=0.05$ ) starp slāṇiem $2 \mathrm{~mm}, 4 \mathrm{~mm}$ un 6 mm dziḷumā no dēḷa virsmas.}

Pētījumā, kurā tika modificēti 50 mm biezi dēḷi un tad salīdzināta krāsa starp slāni $3 \mathrm{~mm}$ zem virskārtas ar dēḷa centru, novēroja ievērojami lielākas krāsu atšķirīibas - vidēji 3.4 $\Delta$ Eab vienības, kas ir labi saskatāmas, tādēl termiski modificētas koksnes krāsa tika vērtēta kā nehomogēna (Johansson and Morén, 2006). Acīm redzot, dēla biezums var būtiski ietekmēt modificētā materiāla krāsas homogenitāti tā tilpumā. Šajā darbā šis aspekts netika izvērtēts.

Koksnes krāsu homogenitātes analīze parāda, ka šajā darbā koksnes termiskajai modifikācijai izmantotajā hidrotermiskās modifikācijas procesā iegūst koksni ar tai raksturīgu krāsu, kura dēlī zem ievērojami tumšākāa virsslāṇa ir gaišāka un visumā homogēna gan viena dēḷa ietvaros, gan starp dēliem.

Pētījuma daḷā par termiski modificētas koksnes krāsas veidošanos modifikācijas procesā un tās homogenitāti ir noskaidrots, ka:

- pieaugot modifikācijas temperatūrai, apses un baltalkšņa koksnes kḷūst arvien līdzīgākas pēc krāsas, un vidējās krāsu atšķirības starp apses un baltalkšņa koksni pēc modifikācijas pie $170^{\circ} \mathrm{C}$ ir vairs tikai divas $\Delta \mathrm{Eab}$ vienības;

- koksnes krāsas maiņa termiskās modifikācijas procesā ir saistîta ar atstarošanas izmaiņām visā redzamās gaismas spektra apgabalā;

- paaugstinot modifikācijas temperatūru, koksnē pieaug hromoforo grupu ar raksturīgu absorbciju redzamās gaismas garāko viḷnu apgabalā ỉpatsvars.

- termiski modificētas koksnes raksturīgo krāsu galvenokārt nosaka oligomēru, un nevis modifikācijas procesā radušos mazmolekulāro, viegli ekstraǵējamo, savienojumu sastāvā ietilpstošas hromoforās grupas;

- termiskās modifikācijas procesā koksnes virsma kḷūst ievērojami tumšāka par dziḷākiem slāņiem;

- termiskās modifikācijas procesā radušos koksnes krāsu zem tumšākā virsslāṇa var uzskatīt par homogēnu, jo vidējās krāsu atškirīibas gan dēḷa vienā plaknē, gan starp dēliem ir mazākas par $3 \Delta$ Eab vienībām. 


\subsection{Termiski modificētas koksnes stabilitāte pret vides faktoru iedarbību}

\subsubsection{Krāsas stabilitāte}

Lietojot koksni kā dekoratīvu materiālu, svarīgs tās kvalitātes rādītājs ir krāsas stabilitāte. Pārsvarā visos pētījumos par koksnes, tai skaitā termiski modificētas koksnes, krāsas stabilitāti tiek analizēta saules vai UV starojuma iedarb̄̄ba uz koksni. Šajā darbā tika pārbaudīta koksnes krāsas stabilitāte, koksnei atrodoties tumsā un istabas apstākḷlos gaismā, kad koksni neskar tieši saules stari. Atrodoties tumsā, koksnē nenotiek gaismas fotonu ierosinātas reakcijas, un vien̄̄gais krāsas izmainu cēlonis ir oksidācijas reakcijas ar gaisa skābekli. Savukārt istabas apstākḷlos bez tieša saules starojuma iedarbības koksne ir pakḷauta tikai redzamās gaismas viḷnu apgabala iedarbībai. Eksperiments ilga 30 mēnešus. Rezultāti parādīja, ka termiski modificētas koksnes krāsu, ja koksni vispār neskar gaismas starojums, var uzskatīt par stabilu, jo, lai arī nelielas, spektrofotometriski fiksējamas krāsas izmaiñas notiek, tās ir par mazu, lai būtu saskatāmas. Savukārt, visiem paraugiem, kuri tika turēti istabas apstākḷos, nelaujot tiešam saules starojumam tos sasniegt, krāsas izmaiņas ir ievērojami lielākas (3.15. att.). Tas parāda, ka arī tikai redzamās gaismas spektru saturošs starojums veicina krāsu izmaiņu kā nemodificētai, tā termiski modificētai koksnei.

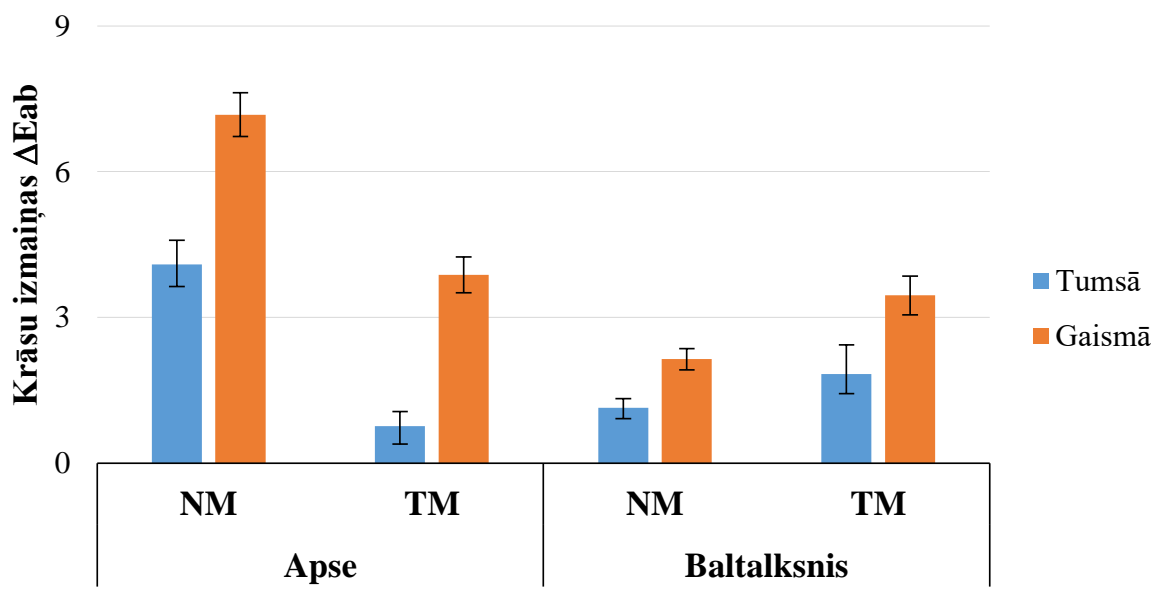

\subsection{5. att. Termiski modificētas (TM) un nemodificētas (NM) apses un baltalkšņa koksnes krāsas izmaiņas $\Delta$ Eab ( \pm standartnovirzes) 30 mēnešu laikā tumsā un istabas apstākḷos bez tiešu saules staru iedarbības.}

Divarpus gadu laikā (30 mēneši) lielākās krāsu izmaiņas gan gaismā, gan tumsā bija nemodificētai apses koksnei, un abos gadījumos krāsu izmaiṇas pārsniedza trīs $\Delta$ Eab vienības. Arī termiski modificētas apses un baltalkšņa koksnei gaismā šajā laikā periodā krāsa mainījās vairāk par trīs $\Delta$ Eab vien̄ibām, un tikai nemodificēta baltalkšņa koksnei krāsas izmaiņas gaismā bija mazākas par trīs $\Delta$ Eab vienībām. 
Analizējot nemodificētas apses un baltalkšņa koksnes atstarošanas izmaiņas pēc 30 mēnešiem, var redzēt, ka vienai sugai izmaiņas tumsā un gaismā visumā ir līdzīgas, tikai atškiras pēc apjoma (3.16. att.). Turklāt abām sugām gan gaismā, gan tumsā koksnei raksturīgā atstarošana samazinās - koksne kḷūst tumšāka. Tomēr, kā tas redzams no atstarošanas izmaiṇu spektriem, pētīto sugu koksnēm ir atšķirīgi maksimālo izmaiṇu spektrālie apgabali. Apsei lielākās atstarošanas izmaiņas ir ap viḷnu garumu $450 \mathrm{~nm}$, bet baltalksnim ap $410 \mathrm{~nm}$. Tas norāda uz atškirirībām hromoforo grupu veidošanās procesos, kas varētu būt saistīts ar atškịiribām to ekstraktvielu sastāvā.

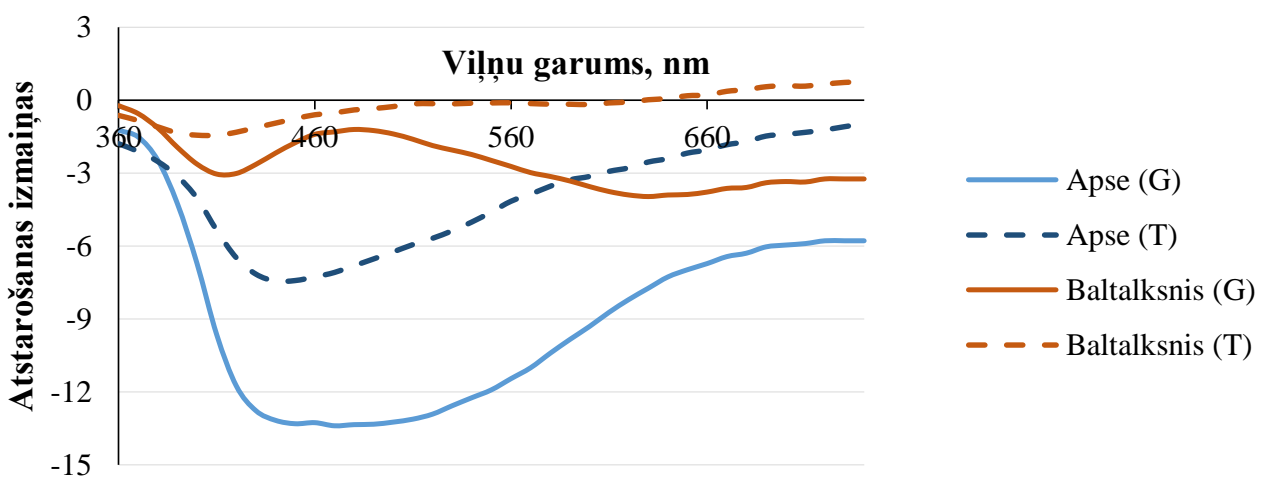

\subsection{6. att. Nemodificētas apses un baltalkšņa koksnes atstarošanas izmaiṇas pēc 30 mēnešiem dažādos apstākḷos.}

Apzīmējumi: G - koksne atradusies gaismā bez tiešiem saules stariem; T - koksne turēta tumsā.

Termiski modificētai koksnei $\left(170^{\circ} \mathrm{C}\right)$ atstarošanas izmaiņas gaismā un tumsā būtiski atšķiras ne tikai pēc apjoma, bet arī rakstura. Koksnei, kura atradās gaismā, atstarošana palielinās, kas nozīmē, ka koksne kḷūst gaišāka, bet tumsā turētajai koksnei samazinās, koksne kḷūst tumšāka (3.17. att.).

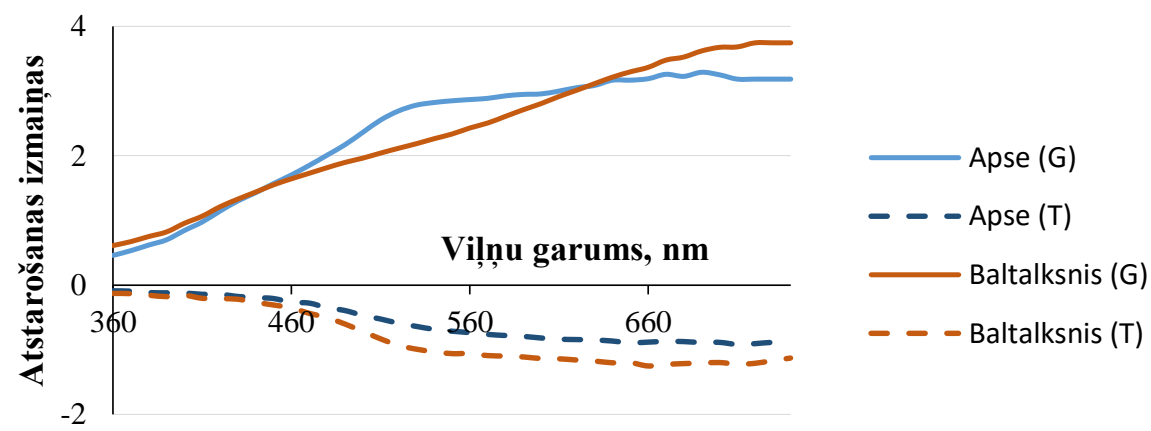

\subsection{7. att. Termiski modificētas $\left(1^{\circ}{ }^{\circ} \mathrm{C}\right)$ apses un baltalkšṇa koksnes atstarošanas izmainas pēc 30 mēnešiem dažādos apstākḷos.}

Apzīmējumi: G - koksne atradusies gaismā bez tiešiem saules stariem; T - koksne turēta tumsā.

Taču, atšķirībā no nemodificētas koksnes, abu sugu termiski modificētai koksnei atstarošanas izmaiṇu raksturs vienādos apstākḷos ir līdzịgs. Tas liecina par abu sugu termiski modificētas koksnes līdzīgām ķīmisko struktūru izmain̄ām novecošanās procesos, un apstiprina augstāk izteikto domu par atšķirīgu ekstraktvielu sastāvu kā 
galveno iemeslu dažādam atstarošanās izmaiņu raksturam nemodificētai apsei un baltalksnim.

Regulāri spektroskopiski mērījumi koksnei visu 30 mēnešu laikā ḷauj izsekot krāsu izmaiņām. Ir redzams, ka termiski modificētai koksnei šis process sastāv no reakcijām, kuru rezultātā ar koksnes hromoforajām sistēmām notiek dažādas izmaiņas, kuras var novērot, kā atstarošanas spektru atšḳirīgas izmaiṇas dažādos viḷnu apgabalos dažādos koksnes novecošanās laika posmos. Termiski modificētas $\left(170^{\circ} \mathrm{C}\right)$ apses koksnes atstarošanas spektra izmaiņas (katram viḷnu garumam atbilstošās izmaiṇas attēlotas kā stabiṇš) pēc dažādiem laika periodiem, koksnei atrodoties gaismā bez tiešas saules staru iedarbības, ir parādītas 3.18. attēlā.
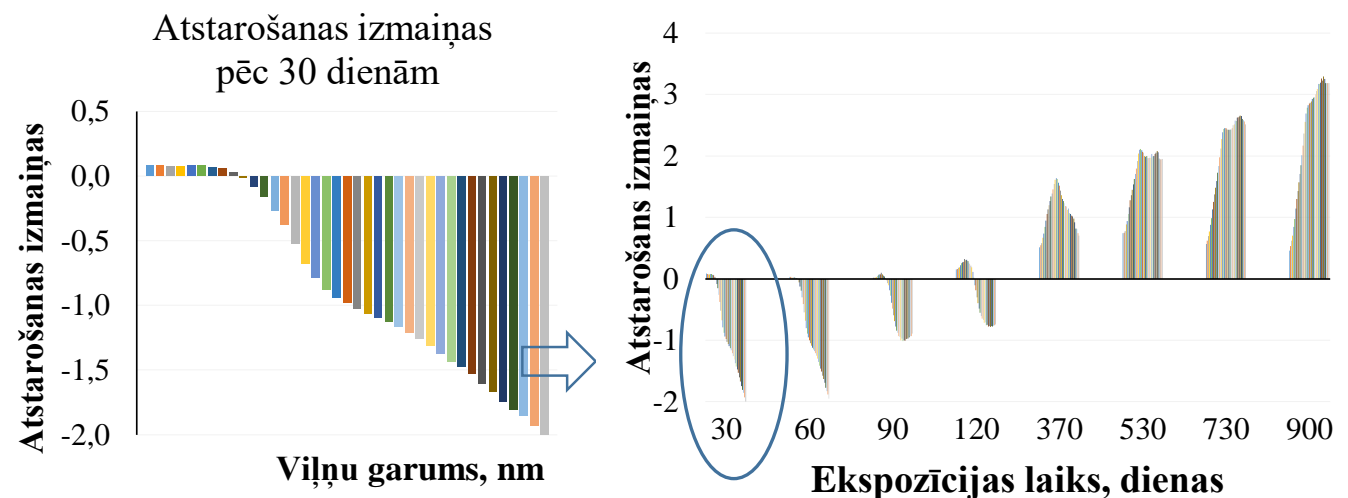

\subsection{8. att. Termiski modificētas $\left(\mathbf{1 7 0}^{\circ} \mathrm{C}\right)$ apses koksnes atstarošanas spektru izmaiṇas laikā koksnei atrodoties gaismā bez tiešu saules staru iedarbības.}

Ekspozīcijas sākumā atstarošana samazinās gandrīz visā redzamās gaismas spektra apgabalā, bet ar laiku, sākot no īsāko viḷnu apgabala, sāk pieaugt, un pēc gada (370 dienām) atstarošana ir pieaugusi jau visā spektra apgabalā un turpina augt. Lielākās izmaiņas gan atstarošanas samazinājuma, gan palielinājuma ziņā notiek spektra garāko vilunu apgabalā, kas norāda, ka hromoforās grupas ar raksturīgu absorbciju šajā apgabalā ir primārās ar termiski modificētas koksnes krāsas izmainuu saistītās kịimiskās struktūras. Arī tumsā turētai termiski modificētai koksnei atstarošanas spektru izmainu raksturs mainās laika gaitā, bet pārmainas ir daudz lēnākas, un pēc 30 mēnešiem, salīdzinot ar izejas rādītājiem, atstarošana ir mazāka visā redzamās gaismas apgabalā, kā tas ir redzams 3.17. attēlā.

Salīdzinot krāsas stabilitāti dažādās temperatūrās modificētai apses koksnei, redzams, ka, pieaugot modifikācijas temperatūrai, palielinās krāsas izmaiṇas, koksnei atrodoties gaismā, bet samazinās izmaiņas tumsā (3.19. att.). Līdzīgi rezultāti tika novēroti arī baltalkšn,a koksnei. Tomēr, ņemot vērā, ka izmaiņu atšķirības ir nelielas un nav statistiski būtiskas ( $\mathrm{p}>0.05$ ), var secināt, ka šajā darbā pētītajām modificētajām koksnēm krāsas stabilitāte gan tumsā, gan gaismā bez tiešu saules staru iedarbības ir līdzīga pie visām analizētajām modifikācijas temperatūrām. 


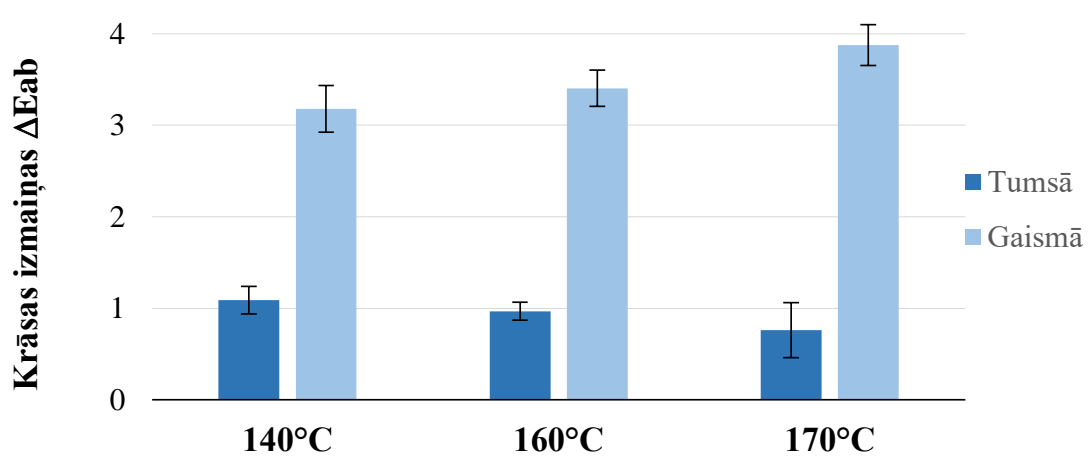

\subsection{9. att. Dažādās temperatūrās modificētas apses koksnes krāsas izmaiṇas $\Delta E a b$ ( \pm standartnovirzes) pēc 30 mēnešiem gaismā un tumsā.}

Koksne biežāk tiek izmantota vietās, kur tā ir pakḷauta saules starojuma iedarbībai - pilnam saules starojuma spektram āra apstākḷlos vai, tā saucamajai, "saulei caur loga stiklu” (sun through window glass) iekštelpās. Gan saules starojuma kopējā, gan tās starojuma UV spektra daļas intensitāte ievērojami mainās kā diennakts, tā arī gada sezonu laikā, kā arī atkarībā no konkrētajiem metrologiskajiem apstākḷiem. Viena no testiem, kuru laikā tika pētīta koksnes novecošanās saules starojuma ietekmēe, pilna saules starojuma un starojuma UV spektra dalas $(290$ - $390 \mathrm{~nm})$ intensitātes variēšana dažādās dienās pa diennakts stundām, kad paraugi tika eksponēti saules starojumam, parādīta 3.20. attēlā.

(a)

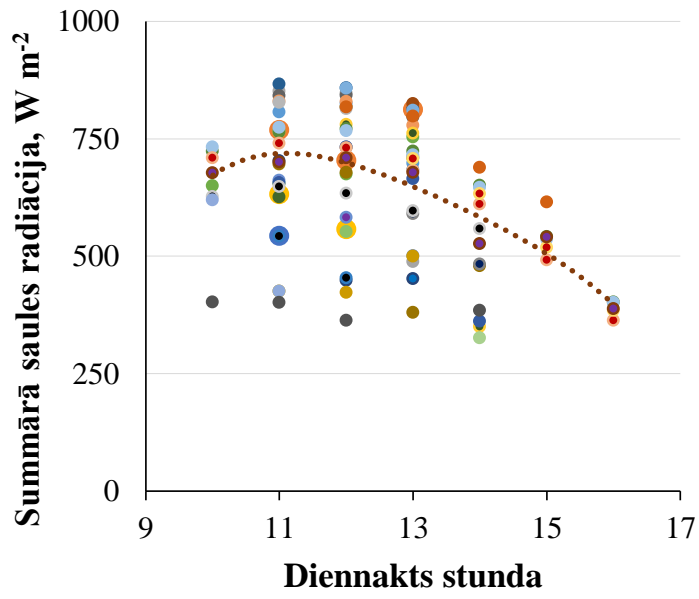

(b)

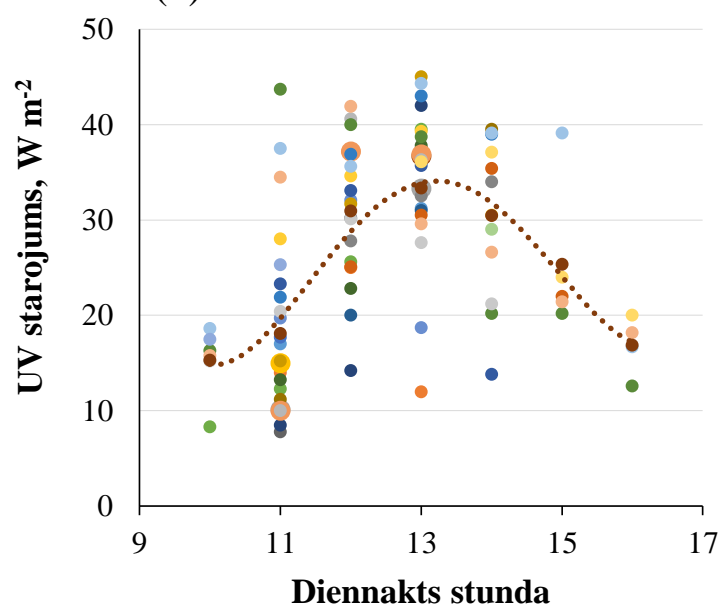

\subsection{0. att. Saules starojuma summārā (a) un saules starojuma UV daḷas (290 - 390} nm) (b) intensitātes variēšana testa laikā.

Redzams, ka starojuma intensitāte variē l,oti plašās robežās. Turklāt pilna saules starojuma un UV starojuma daḷas intensitātes maiņas tendences pa stundām atšķiras. Augstākā kopējā saules starojuma intensitāte ir starp plkst. 11 un 12, bet augstākā UV starojuma intensitāte - ap plkst. 13. Ievērojami variē un pa diennakts stundām atškikiras arī UV starojuma daḷas īpatsvars pilnā saules spektrā (3.21. att.), kas kopējā saules starojumā šì testa laikā svārstījās no 1\% līdz 9\%, un augstākais tas bija starp plkst. 13 un 14. 


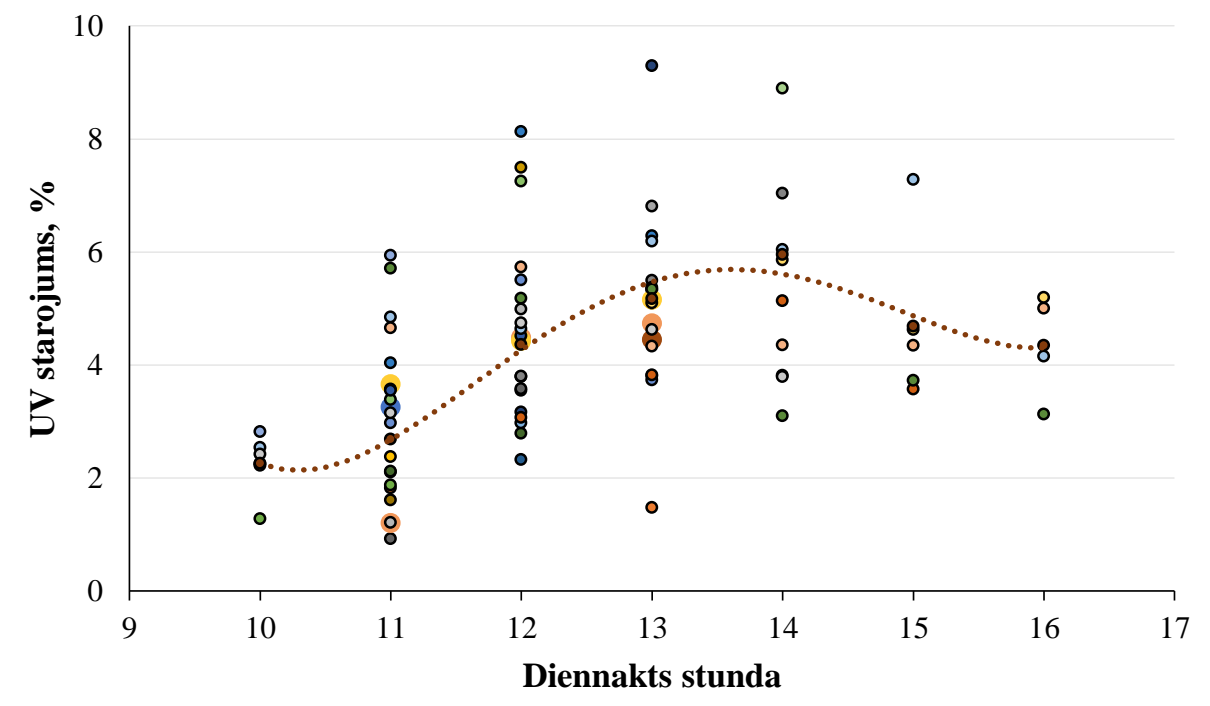

3.21. att. Saules starojuma UV daḷas $(290$ - $390 \mathbf{~ n m})$ īpatsvara variēšana testa laikā.

Testos, kuros tiek pētîta koksnes reakcija uz saules starojumu caur loga stiklu, vēl papildus uz paraugiem nonākošā starojuma variācijas rodas no loga stikla gaismas caurlaišanas īpatnībām. Saules starojums iekštelpās atšķiras gan ar mazāku starojuma kopējo enerğiju, gan starojuma spektrālo sadalījumu. Šajā pētījumā tika fiksēta saules starojuma UV daḷas intensitāte. Viena testa ietvaros fiksētās pilna un caur loga stiklu izgājušā saules spektra UV daḷas $(290$ - $390 \mathrm{~nm})$ intensitātes ir parādītas 3.22. attēlā.

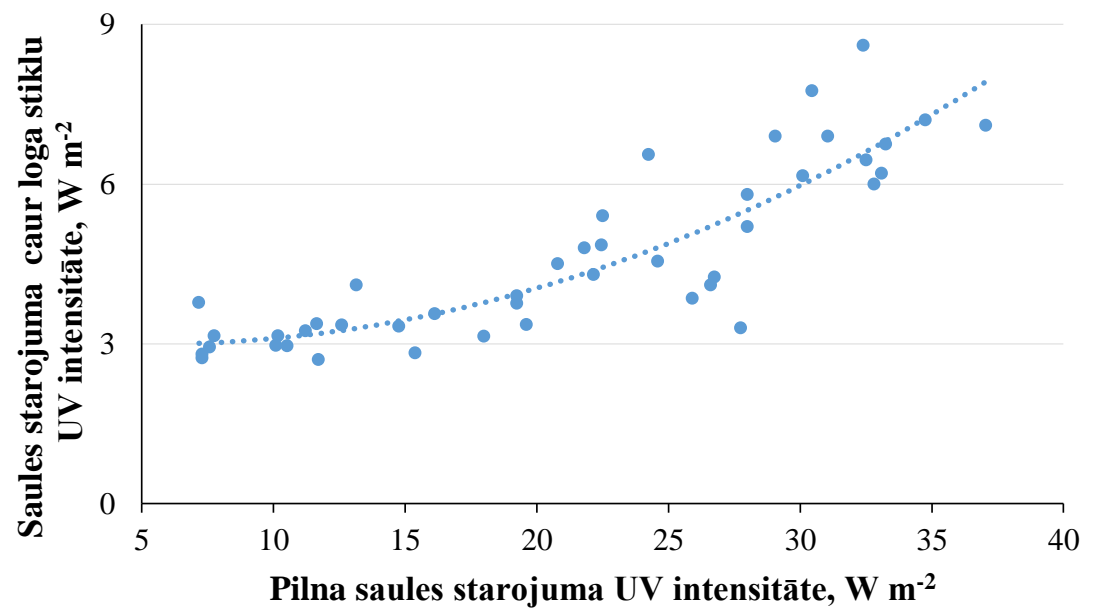

\subsection{2. att. Caur loga stiklu izgājušā saules starojuma UV daḷas $(290$ - 390 nm) intensitāte atkarībā no pilna saules starojuma UV intensitātes.}

Kā redzams, loga stikls bloḳē dalı UV starojuma, bet, pieaugot tā intensitātei, caur loga stiklu caurlaistā UV starojuma intensitāte nepieaug lineāri. Pie zemām UV starojuma intensitātēm caur loga stiklu iziet relatīvi liela UV starojuma dą̧a, bet saules starojuma UV intensitātei palielinoties, caur loga stiklu izgājus̄i daḷa samazinās (3.23. att.). Tas skaidri parāda saules UV starojuma mainīgo kvalitatīvo sastāvu, jo loga stikls galvenokārt aiztur UV-B $(<320 \mathrm{~nm})$ starojumu. 


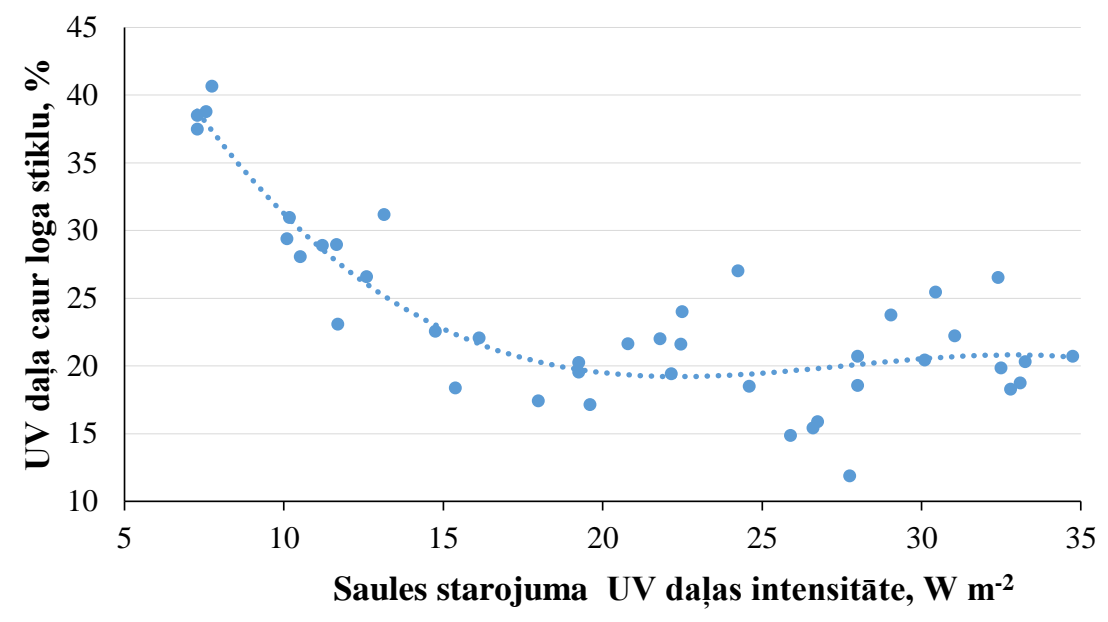

\subsection{3. att. Caur loga stiklu izgājušā UV starojuma daḷa atkarībā no pilna saules starojuma UV $(290$ - $390 \mathrm{~nm})$ daḷas intensitātes.}

Šādas saules starojuma svārstības var būtiski ietekmēt testa rezultātus, kuros paraugi tiek pakḷauti kā saules starojuma ietekmei ārtelpā, tā arī vietās, kurās saules starojums nonāk caur loga stiklu. Dažādos laikos veiktos eksperimentos paraugi vienādā laika intervālā saṇem dažādas saules starojuma devas, un pat vienādas starojuma devas var būtiski atšķirties pēc UV daḷas īpatsvara kopējā starojumā. Šajā darbā visi testi, kuros paraugi tika pakḷauti saules starojuma iedarbībai, tika veikti, tā saucamās, solārās vasaras laikā (7.05. - 6.08.), kad Ziemeḷu puslodē ir augstākā saules enerǵijas intensitāte. Tomēr dažādos gados veiktos testos summārā UV starojuma deva, ko paraugi saṇem vienādā laika periodā, ievērojami atškiriras (3.24. att.).

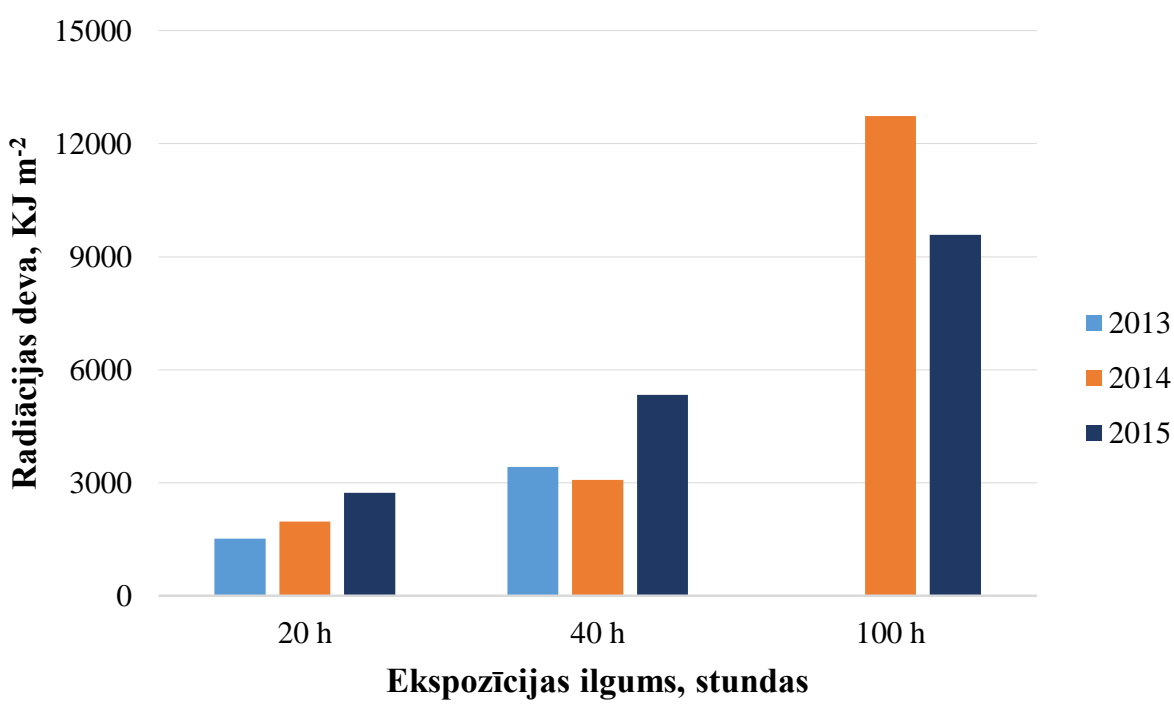

\subsection{4. att. Summārā paraugu saṇemtā saules UV radiācijas deva dažādos gados.}

Starojuma intensitātes mainīguma dēḷ dažādos laikos veiktu testu rezultātus korektāk ir analizēt, izmaiņas attiecinot pret saņemto starojuma devu, nevis ekspozīcijas 
laiku. Salīdzināt var vienlaicīgi eksponētu paraugu izmaiņas, bet dažādu testu rezultātu absolūtās vērtības nav salīdzināmas, tomēr var novērtēt vispārējās tendences.

Testā, kurā nemodificēta un pie dažādām temperatūrām modificēta apses koksne 100 stundas tika eksponēta saulē, modificētā koksne ievērojami mainīja krāsu, lai arī mazākā apjomā nekā nemodificēta koksne (3.25. att.).

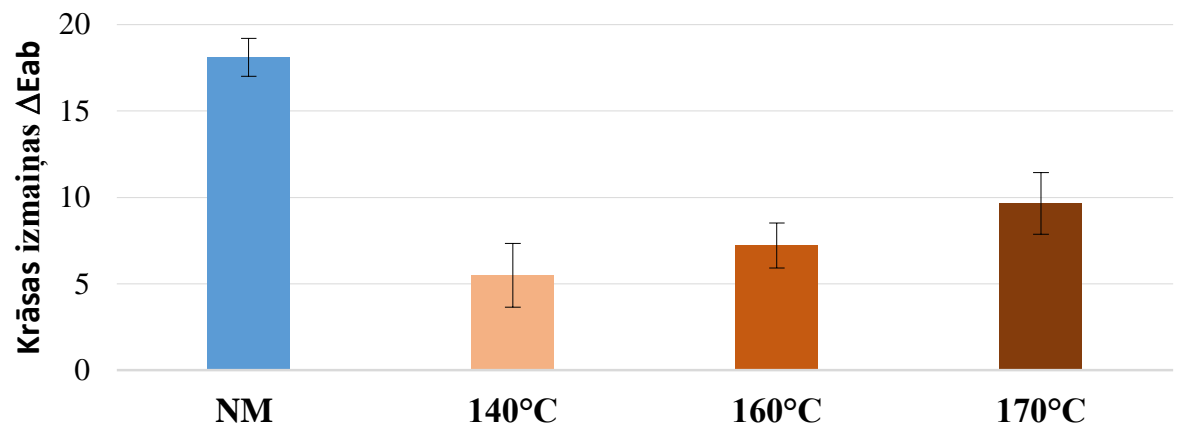

\subsection{5. att. Nemodificētas (NM) un pie dažādām temperatūrām modificētas apses koksnes krāsas izmaiṇas $\Delta$ Eab ( \pm standartnovirzes) pēc 100 stundu eksponēšanas pilnam saules starojumam.}

Redzams, ka saules starojuma izraisītas krāsu izmaiṇas termiski modificētai koksnei pieaug, palielinoties modifikācijas temperatūrai, kas ir līdzīga tendence, kāda tika novērota termiski modificētai koksnei atrodoties gaismā bez tiešas saules starojuma ietekmes (3.19. att.). Tomēr redzams arī, ka ir relatīvi liela rezultātu izkliede, kas variācijas koeficientu izteiksmē ir: nemodificētai koksnei $(\mathrm{NM})-6 \%$ un pie 140, 160, $170^{\circ} \mathrm{C}$ termiski modificētām koksnēm attiecīgi $\left(140^{\circ} \mathrm{C}\right)-34 \%,\left(160^{\circ} \mathrm{C}\right)-18 \%$ un $\left(170^{\circ} \mathrm{C}\right)-18 \%$. N̦emot vērā lielo rezultātu izkliedi, statistiski būtiskas $(\mathrm{p}<0.05) \mathrm{krāsu}$ izmaiṇu atšķirības ir tikai starp pie 140 un $170^{\circ} \mathrm{C}$ modificētām koksnēm.

Būtiski atškirīgs ir ne tikai saules izraisītu koksnes krāsu izmainu $\Delta$ Eab lielums starp nemodificētu un modificētu koksni, bet arī to raksturs. Principiāla atšķirīiba ir pretēja virziena gaišuma izmaiņas. Nemodificēta koksne kḷūst tumšāka, bet pie visām temperatūrām termiski modificēta koksne izbalē. Tas ir labi redzams koksnes atstarošanas spektru izmaiṇās (3.26. att.).

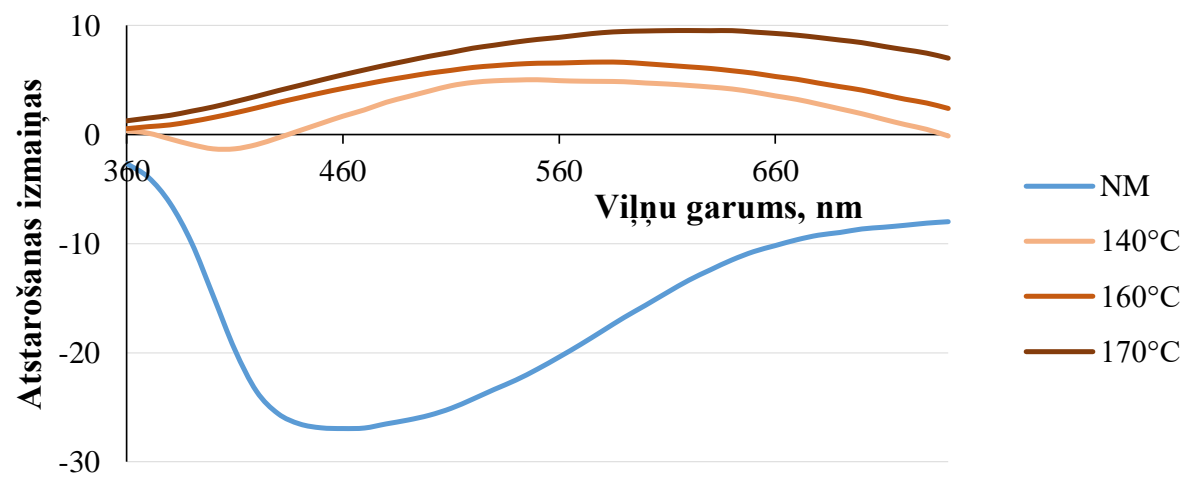


No spektru izmaiṇām redzams, ka pie 160 un $170^{\circ} \mathrm{C}$ modificētām koksnēm atstarošanas spektru izmaiņas ir līdzīgas, kas liecina par līdzīgi uz saules starojumu reaǵējošām hromoforajām sistēmām šajās koksnēs. Savukārt pie $140^{\circ} \mathrm{C}$ modificētas koksnes atstarošanas spektru izmaiņas īsāko viḷnu apgabalā vairāk līdzinās nemodificētas koksnes izmaiņām šajā apgabalā. Acīm redzot, modifikācijas laikā pie zemākām temperatūrām koksnē saglabājas ķīmiskās struktūras, kurās gaismas iedarbības rezultātā veidojas hromoforās grupas ar raksturīgu absorbciju šai apgabalā.

Salīdzinot saules starojuma izraisītas atstarošanas spektru izmainas pie $170^{\circ} \mathrm{C}$ modificētai apses un baltalkšņa koksnei, var secināt, ka, lai arī atšķirīgas pēc apjoma, tās tomēr ir līdzīgas pēc rakstura (3.27. att.).

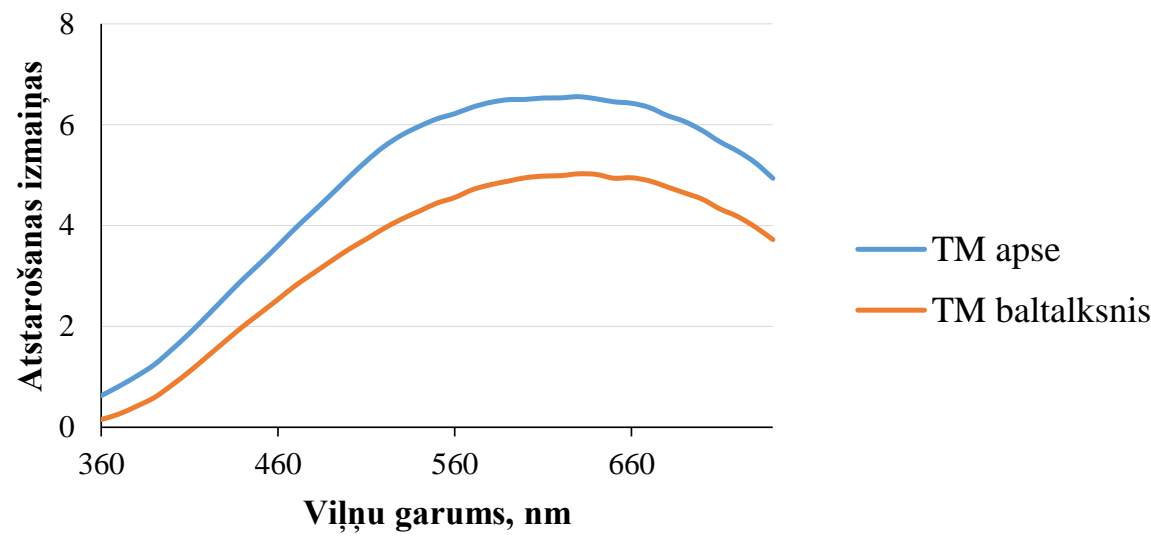

\subsection{7. att. Termiski modificētas $\left(1^{\circ}{ }^{\circ} \mathrm{C}\right)$ apses un baltalkšṇa koksnes atstarošanas spektru izmainas pēc 30 stundu ekspozīcijas saules starojumam.}

Pētījumos par saules ietekmi uz koksnes novecošanās procesiem bieži dabīgs saules starojums tiek imitēts ar dažāda veida mākslīgo starojumu, kas nodrošina atkārtojamus un salīdzināmus eksperimentus. Novecošanās procesus paātrināšanai plaši tiek lietotas dažādas UV starojumu emitējošas lampas, jo ir vispāratzīts, ka tieši saules starojuma UV spektra daļa izraisa būtiskākās pārmaiņas koksnē (Feist, 1990a; Hon, 2000; Heitner, 2010). Lai noskaidrotu, cik labi termiski modificētas koksnes novecošanās procesus var pētīt izmantojot UV starojumu, tika veikts eksperiments, kurā nemodificēta un termiski modificēta $\left(170^{\circ} \mathrm{C}\right)$ apses koksne 40 stundas tika eksponēta četriem dažādiem filpostarojuma veidiem. Informācija par eksperimentā izmantoto starojumu ir apkopota 3.3. tabulā.

3.3. tabula

Dažādiem starojuma veidiem eksponētas koksnes saṇemtās kopējās UV starojuma $(290$ - $390 \mathrm{~nm})$ devas 40 stundu laikā

\begin{tabular}{|c|c|c|c|}
\hline $\begin{array}{l}\text { Starojuma } \\
\text { apzīmējums }\end{array}$ & Starojuma veids & $\begin{array}{c}\text { UV intensitāte, } \\
\mathrm{W} \mathrm{m} \text { m}^{-2}\end{array}$ & $\begin{array}{r}\text { UV deva, } \\
\mathrm{KJ} \mathrm{m}^{-2}\end{array}$ \\
\hline Saule $-\mathrm{A}$ & Pilns saules starojums & $7.2-39.5$ & 3081 \\
\hline Saule - B & Saules starojums caur loga stiklu & $2.7-8.6$ & 665 \\
\hline $\mathrm{UV}-\max$ & UV starojums kamerā & 30.5 & 4392 \\
\hline $\mathrm{UV}-\min$ & UV starojums kamerā & 21.5 & 3096 \\
\hline \multicolumn{3}{|c|}{ Kopējā pilna saules starojuma deva (Saule - A) } & 106700 \\
\hline
\end{tabular}


Pie visiem analizētajiem starojumu veidiem, salīdzinot abas pêtītās koku sugas, lielākas krāsu izmaiņas $\Delta \mathrm{Eab}$ ir gan nemodificētai, gan termiski modificētai apses koksnes (3.28.att.). Lai arī daudz lielākas atšķirības ir starp abu sugu nemodificētas koksnes izmaiṇām, būtiskas krāsas izmaiṇu atškiirības $(\mathrm{p}<0.05)$ ir arī starp apses un baltalkšņa modificētajām koksnēm.

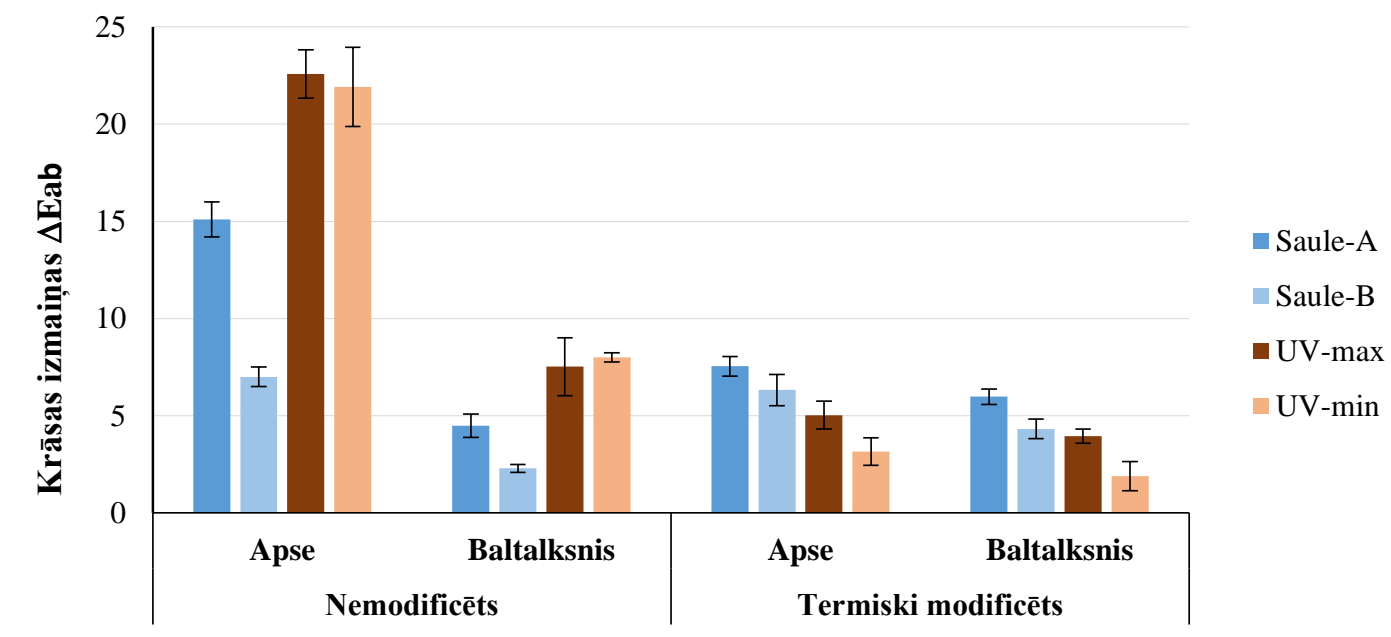

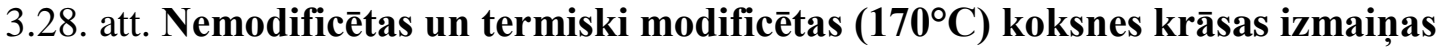 $\Delta$ Eab ( \pm standartnovirzes) pēc 40 stundu ekspozīcijas dažāda veida starojumiem.}

Tomēr abu sugu koksnēm ir vērojamas vienādas krāsu izmaiṇu tendences atkarībā no izmantotā starojuma. Nemodificētai koksnei ievērojami mazākas krāsu izmaiņas $\Delta \mathrm{Eab}$ ir paraugiem, kuri tika eksponēti saules starojumam caur logu stiklu un san̄ēma mazāko UV starojuma devu. Toties ievērojami lielākas krāsu izmaiņas nemodificētai koksnei ir abos UV starojuma kameras testos, lai arī kopējā paraugu saņemtā UV deva pilna saules starojuma (Saule-A) un kameras (UV-min) testā ir līdzīgas (3.3. tab.). Novecināšanas kamerā izmantoto UVA-340 lampu starojuma spektrālajā sadalījumā, salīdzinot to ar saules starojuma spektra UV $(290$ - $390 \mathrm{~nm})$ dalıu, ir liels īsāko viḷnu apgabala īpatsvars (2.7. att.). Tas skaidri parāda, ka nemodificētas koksnes krāsas izmainuu apjoms galvenokārt ir atkarīgs no UV starojuma, un būtiska ietekme ir īsāko viḷnu apgabala ippatsvaram starojumā.

Salīdzinot ar nemodificētu koksni, termiski modificētas koksnes krāsu izmaiṇu $\Delta$ Eab raksturs ir atškirings. Abos testos, kuros koksne tika eksponēta saules starojumam, koksnes krāsu izmaiņas ir lielākas nekā mākslīgā UV starojuma kameras testos. Arī testā, kurā koksne tika eksponēta saules stariem caur logu stiklu (Saule-B) un tās saṇemtā UV starojuma deva bija ievērojami mazāka par citos testos saṇemto, termiski modificētas koksnes krāsu izmaiṇas ir lielākas par krāsu izmaiṇām abos UV kameras testos. Šie rezultāti parāda, ka, salīdzinot ar nemodificētu koksni, termiski modificētas koksnes krāsu izmaiņas daudz mazāk ietekmē UV starojuma devas atšķirības un būtiska nozīme ir saules starojuma garāko viḷnu apgabalam.

Salīdzinot atstarošanas spektru izmaiņas paraugiem pēc novecināšanas pilnā saules starojumā un kamerā UV starojumā, var redzēt, ka nemodificētai koksne izmaiņas ir līdzīgas abiem starojumu veidiem (3.29. att.). Abu starojuma veidu gadījumā maksimālo atstarošanas izmaiņu viḷnu apgabali atšķiras par $20 \mathrm{~nm}$. Tas norāda uz līdzīgām ar koksnes hromoforajām grupām saistītajām ḳīmiskām izmaiṇām koksnē abu starojuma veidu ietekmē. 


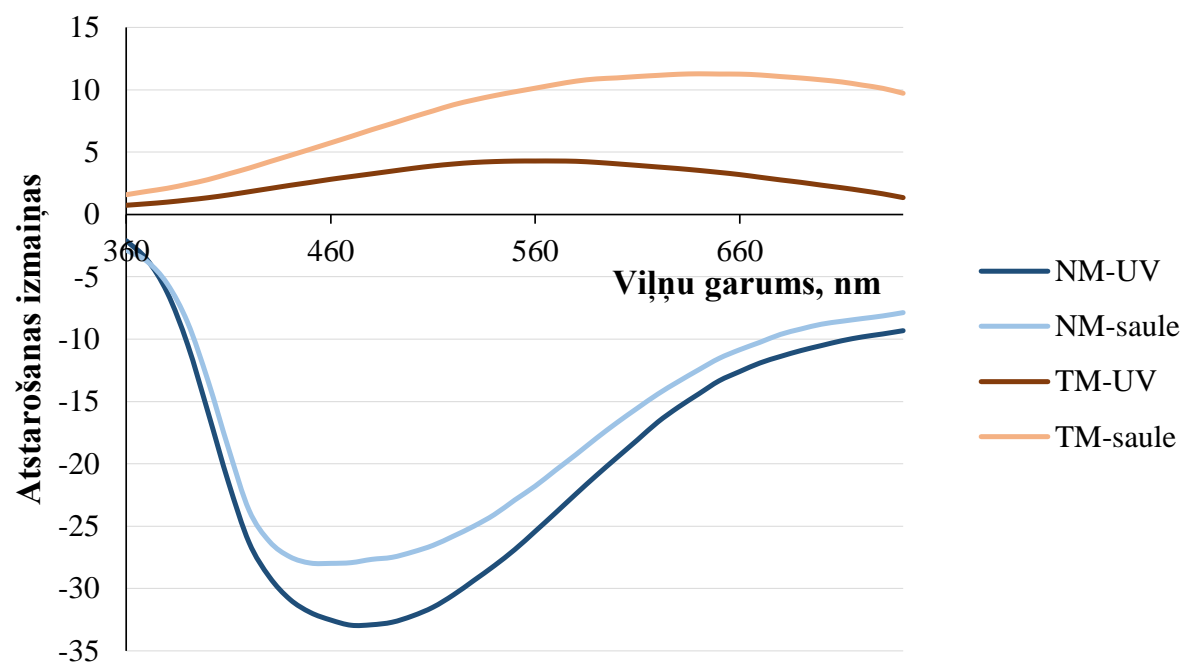

\subsection{9. att. Nemodificētas (NM) un termiski modificētas (TM) apses koksnes atstarošanas spektru izmaiṇas pēc 100 stundu novecināšanas pilnā saulē un kamerā UV starojumā.}

Savukārt termiski modificētai koksnei UV un saules starojuma izraisīto maksimālo atstarošanas izmaiņu apgabali atšķiras par $100 \mathrm{~nm}$, un, salīdzinot ar UV starojumu, saules starojuma ietekmē ievērojami lielākas atstarošanas izmaiņas ir garāko viḷ,nu apgabalā. Tas parāda, ka saules starojums termiski modificētai koksnei izraisa ne tikai lielākas, bet pēc rakstura atšķirīgas krāsu izmaiņas. Arī termiski modificētai baltalkšņa koksnei saules starojums izraisa būtiski lielāku atstarošanas pieaugumu redzamās gaismas garo viḷnu apgabalā, un abu šajā darbā izmantoto sugu termiski modificētām koksnēm saules un UV starojuma izraisīto atstarošanas izmaiṇu atškirīības ir loti līdzīgas (3.30. att.). Šie rezultāti ḷauj secināt, ka iesaistītās ḳimiskās struktūras un procesi ir līdzīgi, un termiski modificētas apses un baltalkšņa koksnes novecošanās tendences neatšķiras.

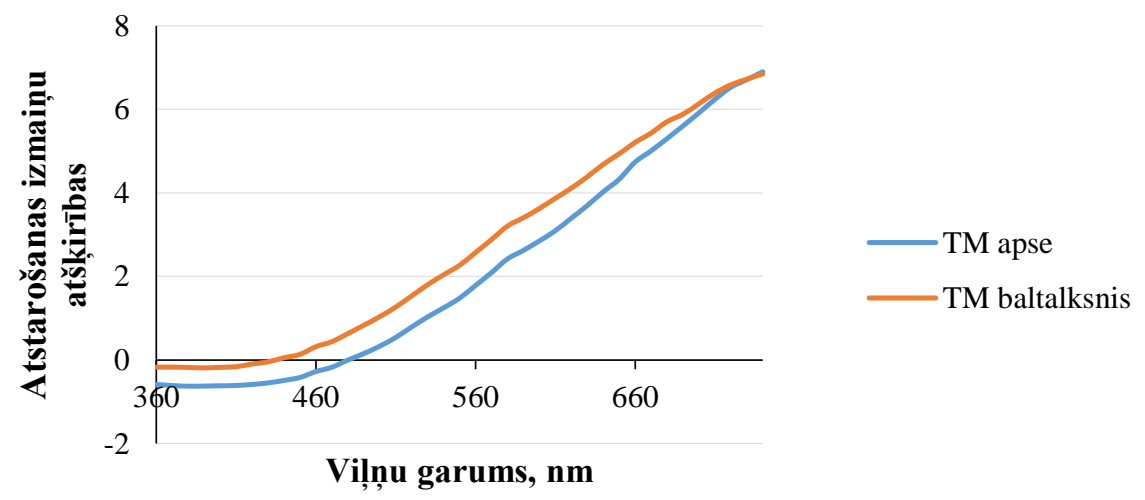

3.30. att. Termiski modificētas apses un baltalkšņa koksnes atstarošanas izmaiṇu atšḳirības starp novecināšanu pilnā saules starojuma un UV starojuma ietekmē. 
Koksnes novecošanās eksperimentos iegūtie rezultāti parāda, ka termiski modificētai koksnei atšķiras saules un UV starojuma izraisīti novecošanās procesi. Turklāt šie rezultāti norāda uz termiski modificētas koksnes salīdzinoši augsto jutību pret saules starojuma redzamās gaismas viḷnu apgabalu. Lai izvērtētu dažādu saules starojuma redzamās gaismas apgabalu ietekmi uz koksni, nemodificēta un termiski modificēta koksne tika eksponēta saules starojumam zem filtriem, kuri atšḳ̄īās ar caurlaistās gaismas spektrālo sastāvu. Filtru gaismas caurlaišanas spektri ir parādīti 2.5. attēlā.

Pētījums parādīja, ka krāsas izmaiņu tendence atkarībā no uz paraugiem nonākošā starojuma spektrālā sastāva atšķiras nemodificētai un termiski modificētai koksnei. Termiski modificētas $\left(170^{\circ} \mathrm{C}\right)$ apses koksnes krāsas izmainas pēc paraugu 100 stundu ekspozīcijas visiem pētītajiem saules starojuma viḷnu apgabaliem virs $400 \mathrm{~nm}$ ir būtiski lielākas ( $\mathrm{p}<0.05)$, salīdzinot tās ar nemodificētas koksnes krāsas izmaiṇām vienādos apstākḷos (3.31. att.). Turklāt termiski modificētai koksnei arī starojums ar viḷnu garumu virs $600 \mathrm{~nm}$ izraisa labi saskatāmas krāsas izmainas $(\Delta \mathrm{Eab}-3.8)$. Toties salīdzinoši nelielas izmaiñas termiski modificētai koksnei rada UV starojums, un tās ir pat būtiski mazākas $(\mathrm{p}<0.05)$ par starojuma ar viḷnu garumu virs $500 \mathrm{~nm}$ izraisītajām.

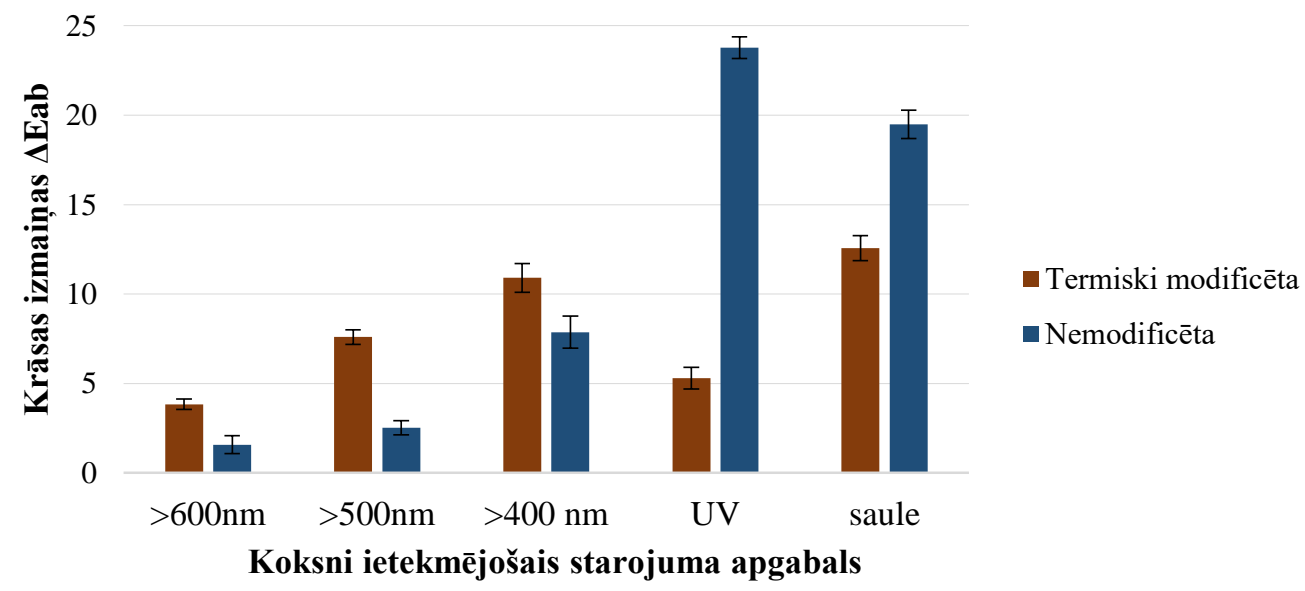

3.31. att. Termiski modificētas $\left(170^{\circ} \mathrm{C}\right)$ un nemodificētas apse koksnes krāsas izmaiņas $\Delta$ Eab ( \pm standartnovirzes) pēc koksnes 100 stundu ekspozīcijas dažādiem saules spektra starojuma apgabaliem zem filtriem.

Ir noskaidrots, ka starojums līdz $515 \mathrm{~nm}$ var izraisīt zināmas krāsu izmaiṇas nemodificētai koksnei (Kataoka et al., 2007; Živkovic, 2014). Šajā darbā nemodificētai koksnei krāsu izmainas tika fiksētas zem visiem izmantotajiem filtriem. Tomēr eksperimenta laika robežās nemodificētai koksnei starojuma ar viḷnu garumu virs $500 \mathrm{~nm}$ izraisītās krāsas izmaiņas bija zem trīs $\Delta$ Eab vienībām, kuras koksnes gadījumā var uzskatīit par nenozīmīgām. Toties UV starojuma izraisītās krāsu izmaiņas nemodificētai koksnei ir pat lielāks par pilna saules spektra radītajām. Līdzīga parādība ir novērota arī pētījumā, kurā daḷa paraugu āra testā bija aizsegti ar tikai UV gaismu caurlaidošiem filtriem (Hon and Minemura, 2000). Tas varētu būt skaidrojams ar dažādu viḷnu garumu starojuma izraisītām atšķirīga, reizēm pat pretēja rakstura koksnes krāsas izmaiṇām (Kataoka et al., 2007).

Termiski modificētas baltalkšņa koksnes krāsu izmaiṇu tendences ir līdzīgas termiski modificētai apsei novērotajām. Abu sugu termiski modificētām koksnēm starojums ar viḷnu garumu virs $500 \mathrm{~nm}$ izraisa krāsu izmaiņas $\Delta \mathrm{Eab}$, kas pēc apjoma ir ap 
75\% no pilna saules starojuma izraisītām izmaiņām (3.32. att.). Savukārt saules starojuma UV daḷas izraisītās krāsu izmaiṇas ir tikai ap 40\% no pilna saules starojuma izraisītajām.

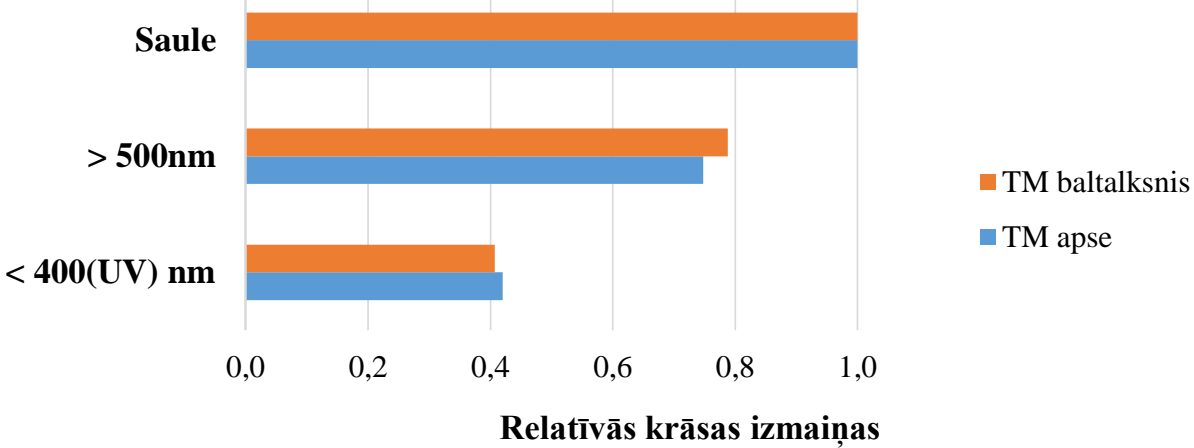

\subsection{2. att. Termiski modificētas apses un baltalkšņa koksnes krāsu izmaiņas UV} starojuma un viḷnu garuma virs $500 \mathrm{~nm}$ ietekmē salīdzinot ar pilna saules spektra izraisītām izmaiṇām.

Dažādo saules spektra viḷnu apgabalu starojuma ietekmes īpatnības uz nemodificētas un termiski modificētas $\left(170^{\circ} \mathrm{C}\right)$ apses koksnes krāsu izmaināàm labi raksturo atstarošanas spektru izmaiņas (3.33. att.).

(a)

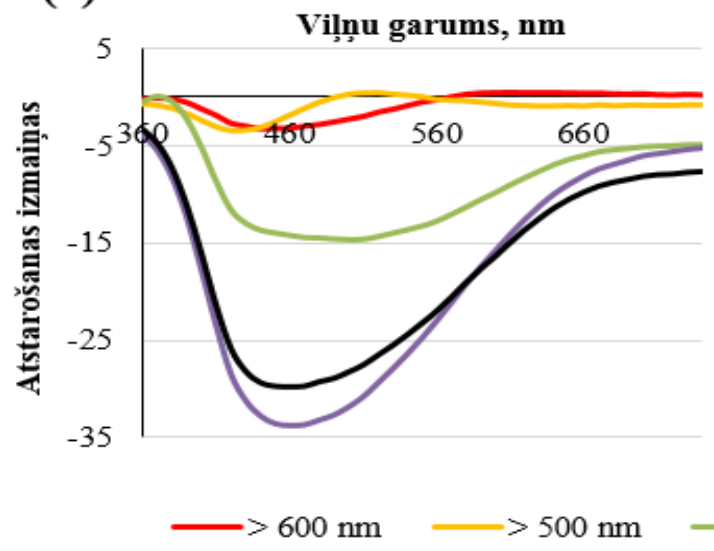

(b)

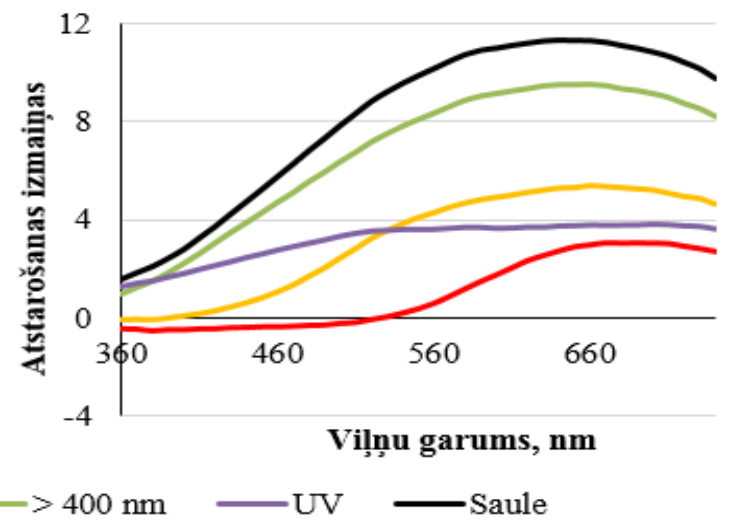

3.33. att. Nemodificētas (a) un termiski modificētas $\left(\mathbf{1 7 0}^{\circ} \mathrm{C}\right)(\mathrm{b})$ apses koksnes atstarošanas spektru izmaiņas pēc koksnes 100 stundu ekspozīcijas dažādiem saules starojuma spektra apgabaliem.

Redzams, ka visu pētīto starojuma apgabalu ietekmes rezultātā nemodificētas koksnes atstarošana samazinās, bet termiski modificētas koksnes atstarošana palielinās gandrīz visā redzamās gaismas spektra apgabalā. Lai varētu salīdzināt atstarošanas izmaiņu apjomu, katram starojuma veidam ir aprēḳināti relatīvie laukumi zem/virs atstarošanas izmaiņu spektriem (3.4. tabula). 
3.4. tabula

Dažādu starojumu izraisīto relatīvo atstarošanas izmaiṇu spektru laukumi, vienības

\begin{tabular}{lccccc}
\hline Koksnes veids & $\mathbf{> 6 0 0} \mathbf{~ n m}$ & $\mathbf{> 5 0 0} \mathbf{~ n m}$ & $\mathbf{> 4 0 0} \mathbf{~ n m}$ & UV & Saule \\
\hline Nemodificēta & $44(23)$ & $43(22)$ & $358(42)$ & $712(24)$ & $685(36)$ \\
\hline Termiski modificēta & $52(24)$ & $124(33)$ & $263(39)$ & $122(12)$ & $317(31)$ \\
\hline Iekavās dotas standartnovirzes & & & & &
\end{tabular}

Dažādo saules spektra viḷnu apgabalu starojuma ierosinātās nemodificētas koksnes krāsas izmaiṇas ir līdzīgas pēc rakstura, tikai atšķiras pēc apjoma, kā to parāda atstarošanas spektru izmaiņas (3.33. (a) att.). Neatkarīgi no starojuma, visiem nemodificētas koksnes paraugiem lielākais atstarošanas samazinājumus ir $400-500 \mathrm{~nm}$ viḷ,nu apgabalā. Tas tiek saistīts ar hinona struktūru veidošanos, kam ir raksturīga absorbcija šajā viḷnu apgabalā (Pandey and Vuorinen, 2008a).

Termiski modificētai koksnei atstarošana palielinās, pakḷaujot to apstarošanai ar visiem šai pētījumā izmantotajiem saules starojuma spektra apgabaliem, bet, atšķirībā no nemodificētas koksnes, pētījumā izmantoto starojuma apgabalu izraisītais atstarošanas izmaiṇu raksturs nav vienāds. Līdzīgas ir atstarošanas izmaiṇas paraugiem, kuri bija eksponēti pilnam saules starojumam un starojumam ar viḷnu garumu virs $400 \mathrm{~nm}$. Abi šie starojumi aptver visu redzamās gaismas spektru, un to izraisītajām atstarošanas izmaiņām ir raksturīgs neliels pieaugums īsāko viḷnu apgabalā un ievērojams pieaugums garo viḷnu apgabalā ar maksimumu ap $650 \mathrm{~nm}$. UV starojums izraisa gandrīz vienādas atstarošanas izmaiṇas visā redzamās gaismas viḷnu apgabalā. Savukārt starojums, kurš aptver tikai saules starojuma garākos viļnu, - virs 500 un $600 \mathrm{~nm}$, tikpat kā neizmaina termiski modificētas koksnes atstarošanu redzamās gaismas īsāko viḷnu apgabalā, bet palielina atstarošanu viḷnu apgabalā virs $450 \mathrm{~nm}$ un $550 \mathrm{~nm}$. Atšḳirīgās izmaiņas termiski modificētas koksnes atstarošanas spektros liek domāt, ka tās sastāvā esošie hromoforie grupējumi ir ar atšķirīgu spektrālo jutîbu un koksne satur pietiekoši daudz ķīmisko grupējumu, kuru izmaiņas var ierosināt arī saules starojuma garāko viḷnu apgabali. Šie rezultāti norāda, ka termiski modificētas koksnes dekoratīvo īpašību saglabāšanai svarīgi ir maksimāli pasargāt to ne tikai no UV starojuma, bet arī starojuma vismaz līdz $600 \mathrm{~nm}$ iedarbības.

Otrs būtisks vides faktors, kas ietekmē koksnes novecošanās procesus, īpaši kopā ar saules starojumu, ir ūdens. Ūdens ietekmi uz koksnes novecošanās procesiem visērtāk ir novērot, izmantojot novecināšanas kameras, koksni pakḷaujot pārmaiņus starojuma un ūdens iedarbībai. Šajā darbā šāda koksnes apstrāde tiek saukta par pilnā cikla novecināšanu un apzīmēta ar PC. Lai varētu analizēt ūdens ietekmi uz koksnes izmaiņām novecināšanas laikā, salīdzinot ar izmaiņām, ko rada tikai apstarošana ar UV starojumu, PC testos novecināšanas ilgums tiek norādīts atbilstoši paraugu apstarošanas laikam ar UV, neieskaitot tajā laiku, kad paraugi ir kondicionēti vai apsmidzināti ar ūdeni. Savukārt testa ilgums tiek uzrādīts kā kvadrātsakne no attiecīgajām ekspozīcijas stundām, jo straujākās izmaiṇas parasti notiek ekspozīcijas sākumā, kurām lineārās skalas gadījumā ir grūti izsekot.

Salīdzinot nemodificētas un termiski modificētas koksnes krāsu izmainas $\Delta \mathrm{Eab}$ mākslīgās novecināšanas UV un PC testos, redzams, ka gan UV testā, kā tas jau ir konstatēts iepriekš, gan arī PC testā būtiski lielākas izmaiñas ir nemodificētai koksnei (3.34. att.). Šie rezultāti sakrīt ar citos pētījumos konstatēto (Huang et al., 2012b; Bakali et al., 2014; Deka et al., 2008). 


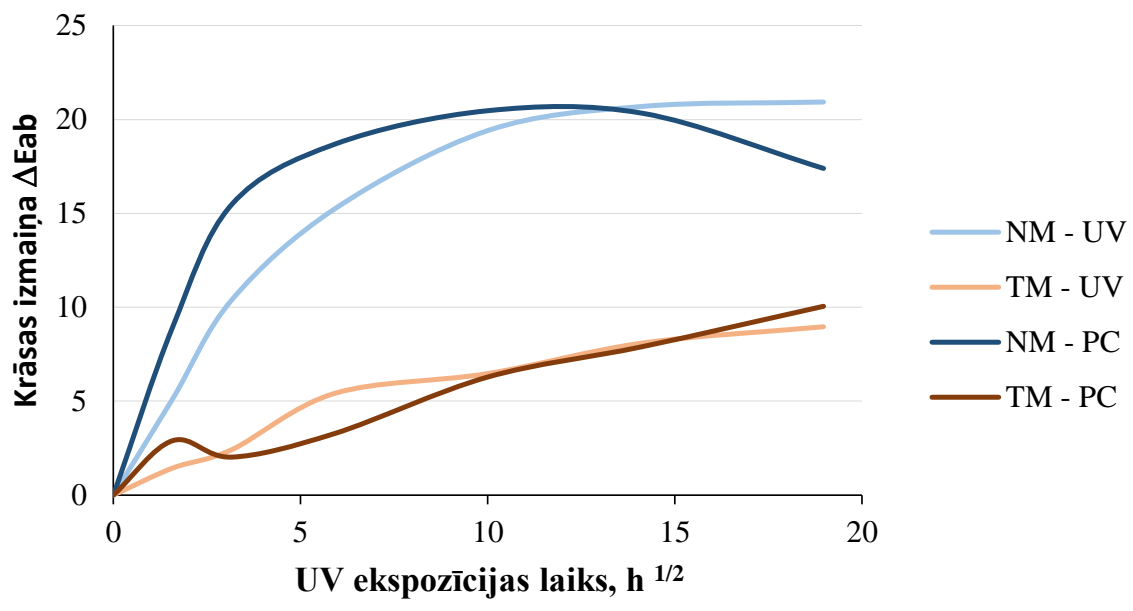

\subsection{4. att. Nemodificētas (NM) un termiski modificētas $\left(\mathbf{1 7 0}^{\circ} \mathrm{C}\right)(\mathrm{TM})$ apses koksnes krāsas izmaiṇas mākslīgās novecināšanas laikā UV un PC testos.}

Nemodificētai koksnei ir raksturīgas īpaši straujas izmaiṇas testu sākumā, kas ar laiku kḷūst lēnākas. Termiski modificētas koksnes krāsas izmainas ir ievērojami lēnākas. Toties ne nemodificētai, ne termiski modificētai koksnei nav lielu krāsas izmaiṇu apjoma atšķirību starp PC un UV testiem (3.32. att.). Šeit jāuzsver, ka krāsas izmaiņas $\Delta$ Eab norāda tikai krāsu izmaiṇu apjomu, nevis virzienu. Tādēḷ krāsu izmaiṇas, it sevišḳi procesos, kuros izmaiņas maina savu virzienu, labāk raksturo krāsu parametri (3.35. att.).

(a)

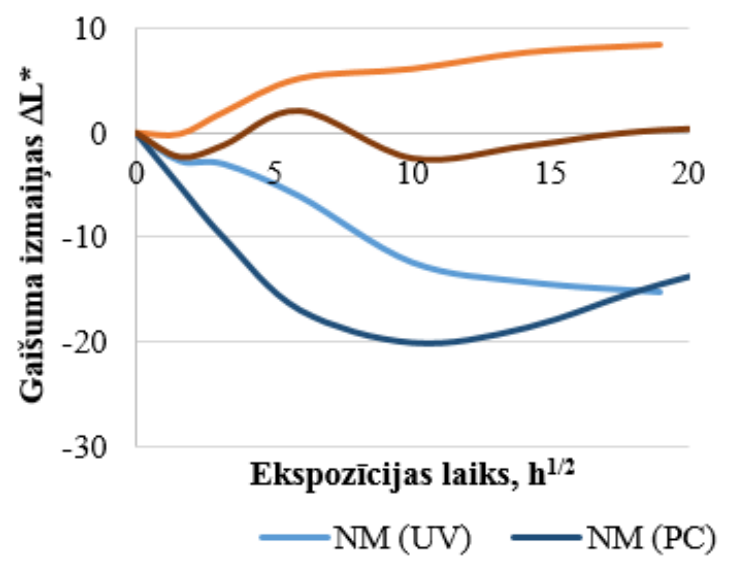

(b)

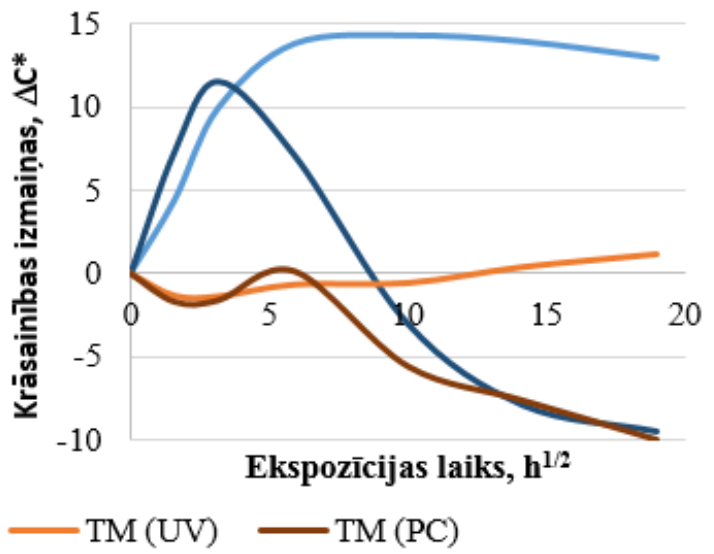

\subsection{5. att. Nemodificētas (NM) un termiski modificētas $\left(170^{\circ} \mathrm{C}\right)(\mathrm{TM})$ apses koksnes gaišuma parametra izmaiņas $\Delta \mathrm{L}^{*}$ (a) un krāsainības izmaiṇas $\Delta \mathrm{C}$ *(b) mākslīgās novecināšana UV un PC testu laikā.}

Kā redzams, PC testa sākumā krāsainības izmainas $\Delta \mathrm{C}^{*}$ gan nemodificētai, gan termiski modificētai koksnei būtiski neatšķiras no izmaiņām UV testā. Bet pēc 10 UV apstarošanas stundām atbilstoša testa laika abu veidu koksnēm krāsainība strauji sāk samazināties. Tas nozīmē, ka šajā brīdi fotodegradācijas produktu izskalošanas procesi kḷūst noteicošie un koksne zaudē savu krāsu, klūstot pelēka. Savukārt UV testā nemodificētas koksnes krāsainība ievērojami palielinās, kas kopā ar būtisko gaišuma L* 
samazināšanos veido nemodificētas koksnes lielās krāsas izmainas UV testā (3.31 att.). Termiski modificētas koksnes krāsainība UV iedarbības rezultātā daudz nemainās, toties tā kḷūst gaišāka. Gaišuma parametrs $L^{*}$ abu veidu koksnēm PC testā pēc sākotnējas pazemināšanās sāk pieaugt. Rezultātā, lai arī koksnēm abos testos ir līdzīga apjoma krāsu izmaiņas, to krāsas pēc UV un PC testiem ir ievērojami atšķirīgas (3.36. att.).

(a)

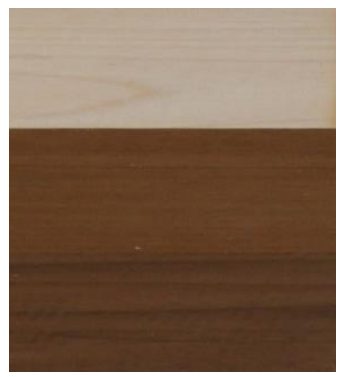

(b)

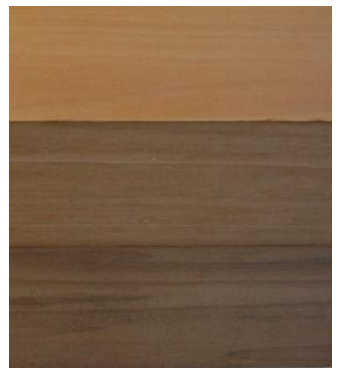

(c)

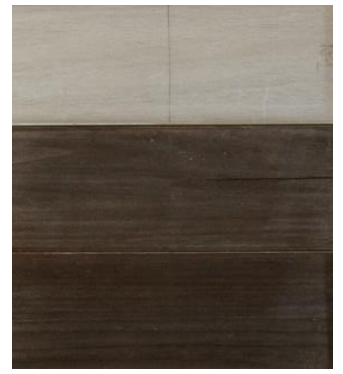

3.36. att. Nemodificētas un termiski modificētas $\left(160\right.$ un $\left.170^{\circ} \mathrm{C}\right)$ (no augšas uz leju) apses koksnes krāsas pirms un pēc mākslīgās novecināšanas UV un PC testiem: (a) pirms testiem; (b) pēc UV testa; (c) pēc PC testa.

Mākslīgās novecināšanas testi tiek izmantoti, lai pētītu un analizētu koksnes novecošanās procesus kontrolētos apstākḷos. Tomēr ir svarīgi, lai šie testi zināmā mērā varētu imitēt reālos apstākḷlos notiekošus procesus. Šajā darbā, lai izvērtētu, cik labi mākslīgās novecināšanas PC tests atspoguḷo koksnes izmainas reālos āra apstākḷıs, ir salīdzināti atstarošanas spektri pirms un pēc āra testa (270 dienas) un PC mākslīgās novecināšanas testa (42 dienas jeb 1000 stundas) (3.37. att.).
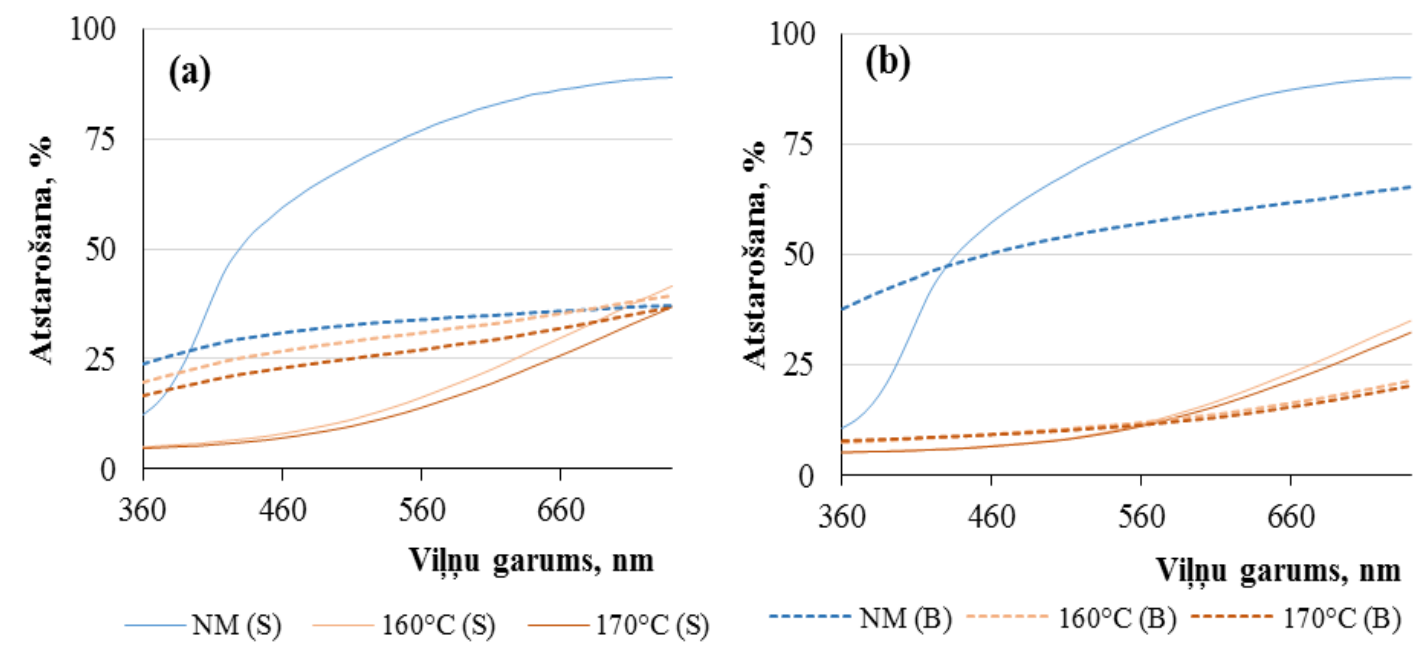

3.37. att. Nemodificētas (NM) un termiski modificētas apses koksnes atstarošanas spektri pirms (S) un pēc (B) novecināšanas: (a) 270 dienas āra tests; (b) 42 dienas PC mākslīgās novecināšanas tests.

Salīdzinot atstarošanas spektrus pēc abiem testiem, ir skaidri redzamas vienādas tendences, tomēr ievērojami lielākas izmaiņas ir āra testa paraugiem. Gan nemodificētai, gan termiski modificētai koksnei abos testos ir raksturīga atstarošanas intensitātes 
izlīdzināšanās visā redzamās gaismas apgabalā. Nemodificētai koksnei tas ir saistìts ar atstarošanas pieaugumu īsāko viḷnu apgabalā līdz $400 \mathrm{~nm}$ un samazināšanos pārējā spektra apgabalā. Termiski modificētai koksnei lielākais atstarošanas pieaugums ir īsāko viḷnu apgabalā. Vienādas intensitātes atstarošana visā redzamās gaismas spektra apgabalā, atkarībā no intensitātes, vizuāli tiek uztverta kā gaišāks vai tumšāks pelēkais tonis. Rezultāti parāda, ka mākslīgajā novecināšanā kamerā testa laika robežās koksnes atstarošanas izmaiņas nav sasniegušas āra testā konstatēto līmeni. Jāṇem gan vērā, ka āra vidē bez abiotiskajiem faktoriem koksni ietekmē arī biotiskie faktori, un, lai arī koksne pirms spektrofotometrisko mērījumu izdarīšanas tiek noslaucīta, koksnes krāsojošās sēnes var atstāt savu iespaidu uz spektrofotometriskajiem mērījumiem.

\subsubsection{Virsmas ḳīmiskās izmainas}

Materiāla ķīmiskās izmaiņas ir būtisks rādītājs novecošanās procesu izvērtēšanā. Koksnes krāsas izmaiņas ir saistītas ar izmaiņām tās ķīmiskajā struktūrā, taču ne visi ķīmiskie procesi ir saistīti ar koksnes krāsas izmain̄ām. Koksnes novecošanās ir izteikts virsmas process, kurā izmaiņas notiek tikai dažu šūnu kārtu dziļumā (Feist and Hon, 1984). Tas ir labi redzams, mikroskopiski apskatot koksni pēc tās ekspozīcijas UV starojumam (3.38. att.).

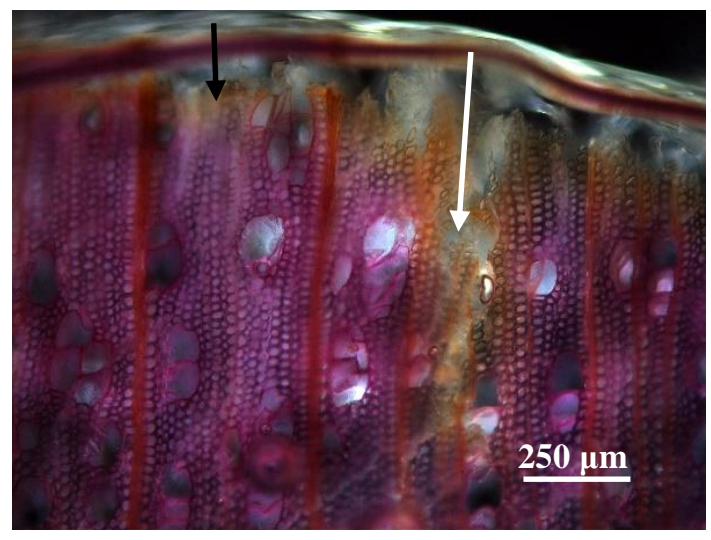

\subsection{8. att. UV starojumam pakḷautas, ar fluoroglucīna šḳīdumu iekrāsotas nemodificētas apses koksnes šḳērsgriezuma attēls.}

Apses koksnē pēc UV apstarošanas, iekrāsojot to ar fluoroglucīnu šķīdumu, kas ar koksnes lignīnu veido sarkanu krāsojumu, augšējās šūnu kārtās (melnā bulta), kā arī šūnās ap koksnes plaisu (baltā bulta), kura ir ḷāvusi UV starojumam iekḷūt dziḷāk koksnē, sarkanais krāsojums neveidojas. Tas norāda, ka šajā koksnes zonā vairs nav lignīna. No attēla redzams, cik plānā koksnes virsējā slānī lignīns ir noārdījies. Tas jāṇem vērā izvēloties metodi ḳīmisko izmainu analīzei. Tādēl koksnes kịmisko izmainu izpētē plaši tiek lietota Furjē transformācijas infrasarkanā spektroskopija (FTIR), izmantojot ATR palīgierīci, kas ḷauj uzņemt un tālāk analizēt tieši koksnes virsmas absorbcijas spektrus.

Koksnes pamatkomponentu funkcionālajām grupām ir raksturīga absorbcija galvenokārt FTIR spektra apgabalā no $850 \mathrm{lī} d z 1800 \mathrm{~cm}^{-1}$. Tomēr koksnes kịimisko izmaiņu analīzei tās novecošanās procesā, izmantojot FTIR absorbcijas spektrus, biežāk lietotie ir karbonilgrupām raksturīgais absorbcijas rajons ap viḷ,nu skaitli $1720 \mathrm{~cm}^{-1}$ un lignīna aromātiskajam gredzenam raksturīgais absorbcijas rajons ap vị̣nu skaitli $1510 \mathrm{~cm}^{-1}$ (Miklečić et al., 2011; Srinivas and Pandey, 2012; Tolvaj and Varga, 2012). 
Eksperimentā, kurā nemodificēta un termiski modificēta koksne tika pakḷauta dažādu 3.3. tabulā raksturoto starojumu iedarbībai, izmantoto paraugu absorbcijas spektri apgabalā no $850 \mathrm{lī} \mathrm{dz} 1800 \mathrm{~cm}^{-1}$, pirms un pēc starojumu iedarbības, ir redzami 3.39. attēlā.

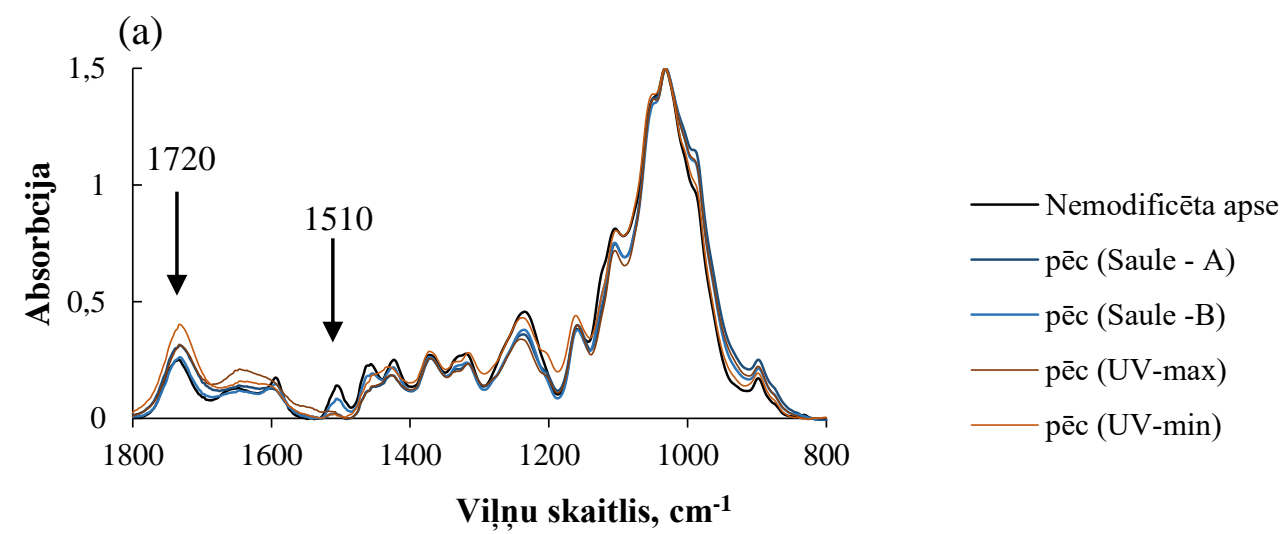

(b)

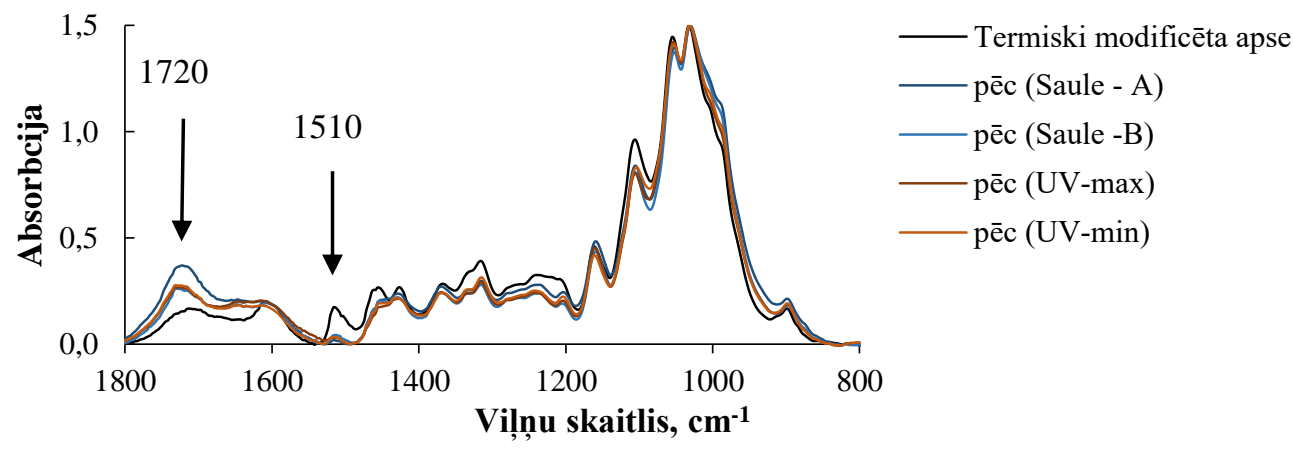

\subsection{9. att. Nemodificētas (a) un termiski modificētas (b) apses koksnes FTIR ATR spektri pirms un pēc 40 stundu eksponēšanas dažādiem starojumiem.}

Gan nemodificētu, gan termiski modificētu koksni pakḷaujot starojuma iedarbībai, raksturīgo absorbcijas spektru apgabalu $\left(1720 \mathrm{~cm}^{-1}\right.$ un $\left.1510 \mathrm{~cm}^{-1}\right)$ izmain̄ām ir līdzīgs raksturs. Līdzīgas starojuma izraisītas absorbcijas izmainas termiski modificētai un nemodificētai koksnei ir novērotas arī citos pētījumos (Deka and Petrič, 2008; Miklečić et al., 2011). Absorbcija rajonā ap $1720 \mathrm{~cm}^{-1}$ palielinās, kas norāda uz koksnes ķīmisko pamatkomponentu oksidācijas procesiem, kuros veidojas karbonilgrupas. Savukārt starojums izraisa koksnes absorbcijas samazināšanos apgabalā ap $1510 \mathrm{~cm}^{-1}$, kas ir saistīts ar lignīna degradāciju. Lai analizētu šos procesus, tika salīdzinātas katra starojuma veida izraisītās koksnes absorbcijas izmaiņas pie šiem viḷ̣nu skaițiem (3.40. att.). 


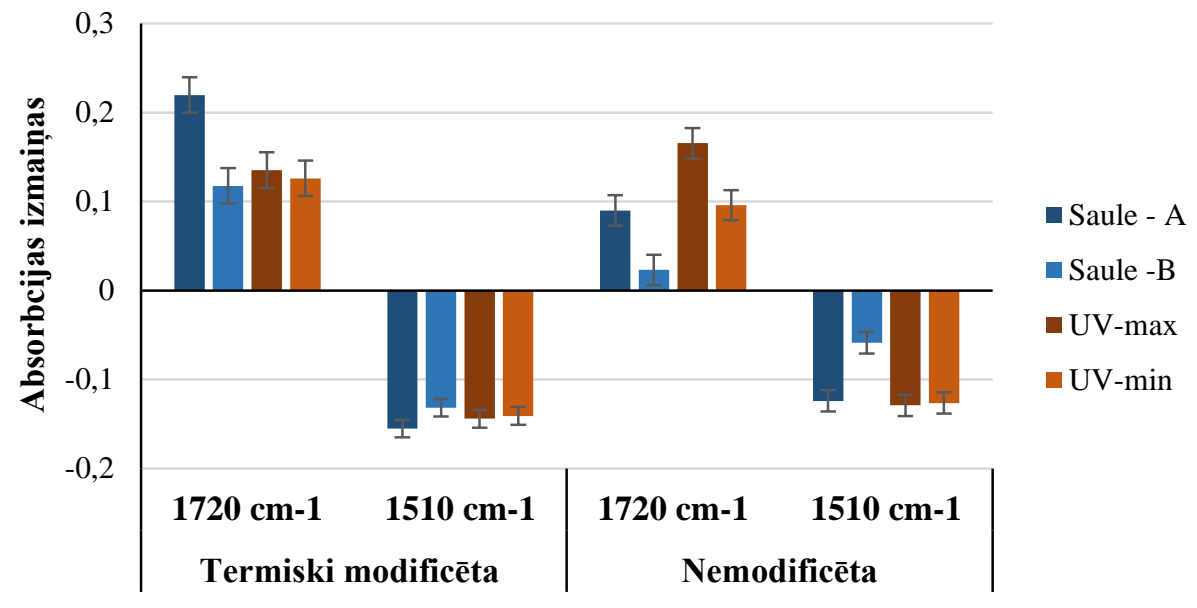

\subsection{0. att. Termiski modificētas $\left(1^{\circ}{ }^{\circ} \mathrm{C}\right)$ un nemodificētas apses koksnes absorbcijas izmaiṇas viḷnu skaitḷu $1510 \mathrm{~cm}^{-1}$ un $1720 \mathrm{~cm}^{-1}$ apgabalos dažādu starojumu iedarbības rezultātā.}

Rezultāti parāda, ka termiski modificētai koksnei būtiski lielākās izmainas rada pilns saules starojums (Saule-A). Pārējo eksperimentā izmantoto starojumu izraisītās izmaiņas ir līdzīgas, un caur loga stiklu izejošais saules starojums (Saule-B), kura UV daļas intensitāte ir relatīvi ḷoti zema, termiski modificētai koksnei izraisa gandrīz tikpat lielas ķīmiskās izmaiņas, kā paraugu novecināšana kamerā UV starojumā. Turklāt termiski modificētai koksnei, salīdzinot ar nemodificētu koksni, visi starojuma veidi, izṇemot augstas intensitātes UV starojumu (UV-max), izraisa ievērojami lielāku ar karbonilgrupām saistīto absorbcijas pieaugumu, kas varētu liecināt par saules starojuma spēju izraisīt relatīvi lielas k̦īmiskas pārvērtības termiski modificētā koksnē. Turpretim nemodificētas koksnes paraugiem starojums ar zemu UV intensitāti (Saule-B) ir radījis arī salīdzinoši mazas ķīmiskās izmaiṇas. N̦emot vērā, ka absorbcijas samazinājumu pie $1510 \mathrm{~cm}^{-1}$ izraisa lignīna degradācija, tā samazinājuma absolūtās vērtības ir saistītas ar izejas materiāla absorbciju šajā apgabalā, un 3.36. attēlā dotās vērtības neḷauj salīdzināt lignīna degradācijas pakāpi termiski modificētai un nemodificētai koksnei. Tādēl, izmantojot izejas materiāla absorbcijas vērtības šajā apgabalā, ir aprēḳināts procentuālais absorbcijas samazinājums apgabalā pie $1510 \mathrm{~cm}^{-1}$ (3.41. att.).

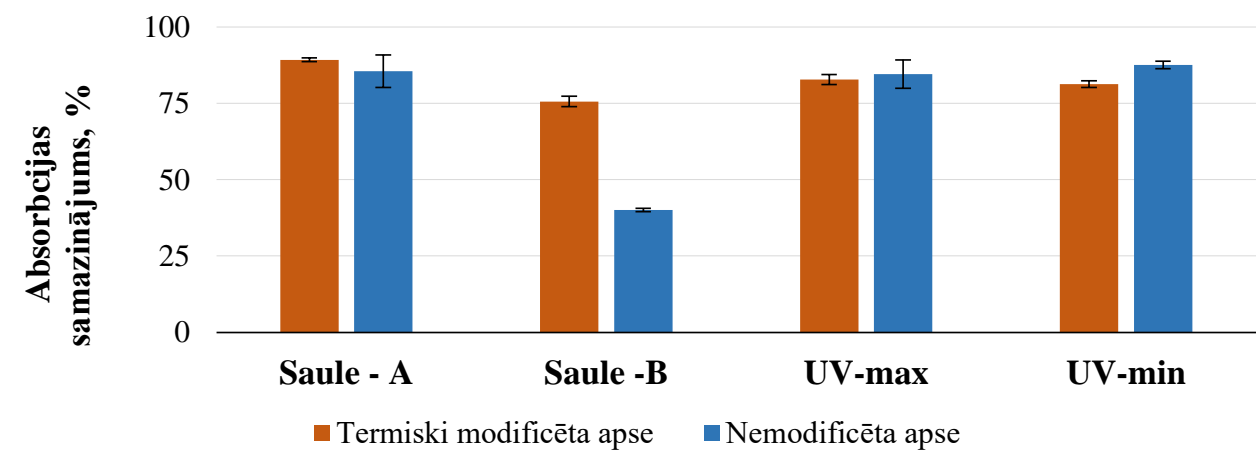

3.41. att. Termiski modificētas $\left(170^{\circ} \mathrm{C}\right)$ un nemodificētas apses koksnes procentuālais absorbcijas samazinājums ( \pm standartnovirzes) $1510 \mathrm{~cm}^{-1}$ apgabalā pēc paraugu 40 stundu apstarošanas ar dažāda veida starojumu. 
Ir redzams, ka, iznemot saules starojumu caur loga stiklu (Saule-B), visi citi starojuma veidi izraisa līdzīga apmēra lignīna degradāciju un nav būtiskas atškirīības $(\mathrm{p}>0.05)$ starp nemodificētu un termiski modificētu koksni. Termiski modificētai koksnei arī starojums ar zemu UV intensitāti (Saule-B) veicina relatīvi lielu lignīna degradāciju, bet nemodificētas koksnes lignīns ir ievērojami rezistentāks pret šādu starojumu.

Dažādu saules starojuma spektra apgabalu izraisītās FTIR absorbcijas spektru izmaiṇas ir parādītas 3.42. attēlā.
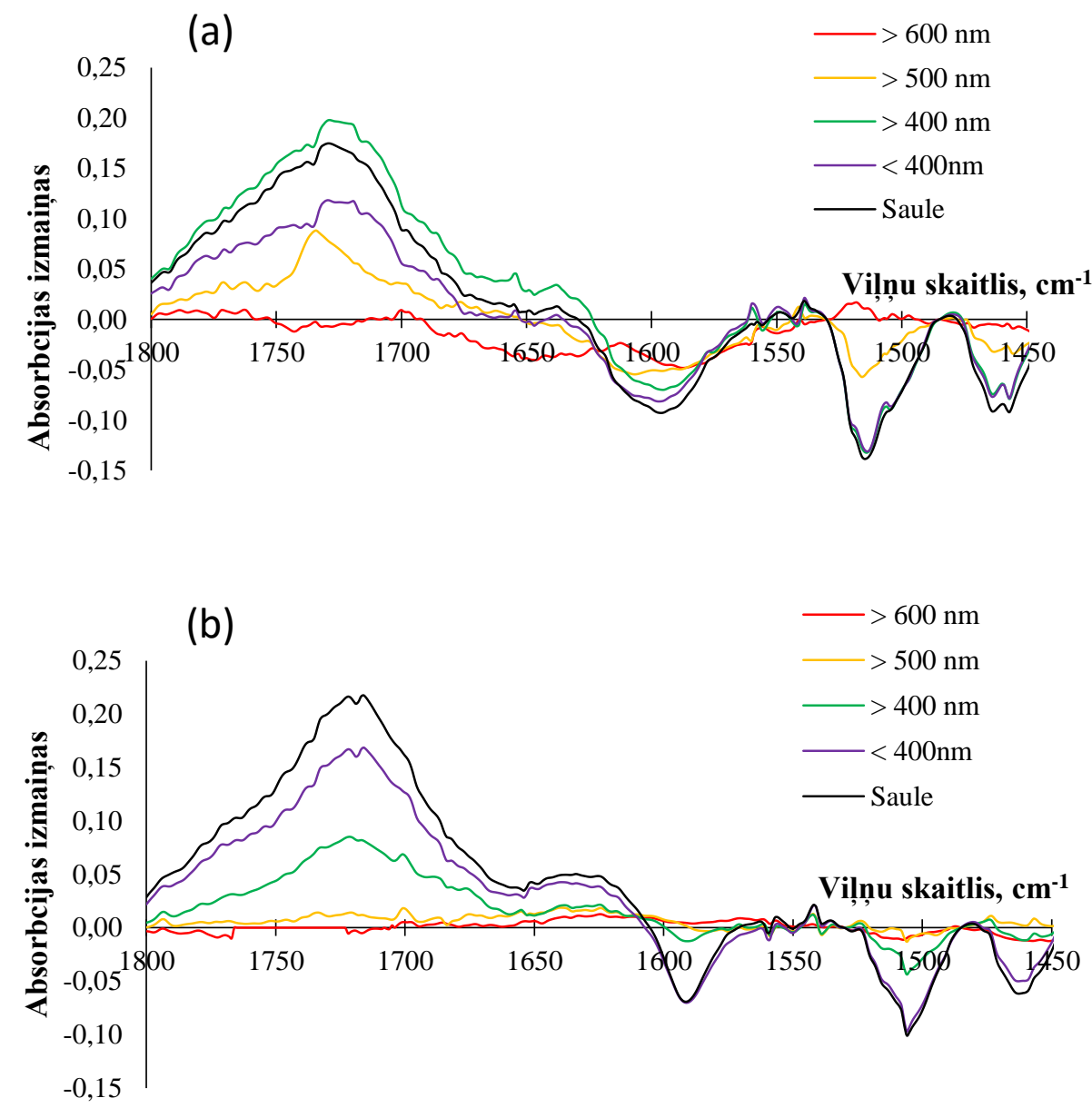

\subsection{2. att. Dažādu saules starojuma spektra apgabalu izraisītās absorbcijas spektru izmaiṇas termiski modificētai $\left(170^{\circ} \mathrm{C}\right)$ (a) un nemodificētai (b) apses koksnei.}

Gan nemodificētas, gan termiski kodificētas koksnes gadījumā absorbcija izmaiņu spektri ievērojami atškiras paraugiem, kas tika pakḷauti dažādiem saules starojuma spektru apgabaliem. Salīdzinot nemodificētas un termiski modificētas koksnes izmainas, redzams, ka termiski modificētai koksnei relatīvi lielas izmaiņas ir izraisījusi saules starojuma redzamās gaismas spektra daḷa virs $400 \mathrm{~nm}$ un pat $500 \mathrm{~nm}$. Nemodificētai koksnei saules starojuma spektra dą̧a virs $500 \mathrm{~nm}$ nav izraisījušas vērā ņemamas absorbcijas spektru izmaiņas. Arī pētījumā, kurā dažādu viḷnu garuma starojumam pakḷāva Cryptomeria japonica koksni, absorbcijas izmainas pie $1730 \mathrm{~cm}^{-1}$ netika konstatētas paraugiem, kurus apstaroja ar starojumu ar viḷnu garumu virs $430 \mathrm{~nm}$ (Kataoka et al., 2007). 
Salīdzinot absorbcijas maksimumu izmaiñas apgabalos ap $1720 \mathrm{~cm}^{-1}$ un $1510 \mathrm{~cm}^{-1}$, redzams, ka termiski modificētas koksnei vienāda apjoma absorbcijas samazinājumu ap viļ̣nu skaitli $1510 \mathrm{~cm}^{-1}$, kas atbilst vairāk nekā $90 \%$ no sākotnējā absorbcijas lieluma, izraisa gan saules starojuma redzamās gaismas daḷa ( $>400 \mathrm{~nm})$, gan UV daḷa $(<400 \mathrm{~nm})$ (3.43. att.).

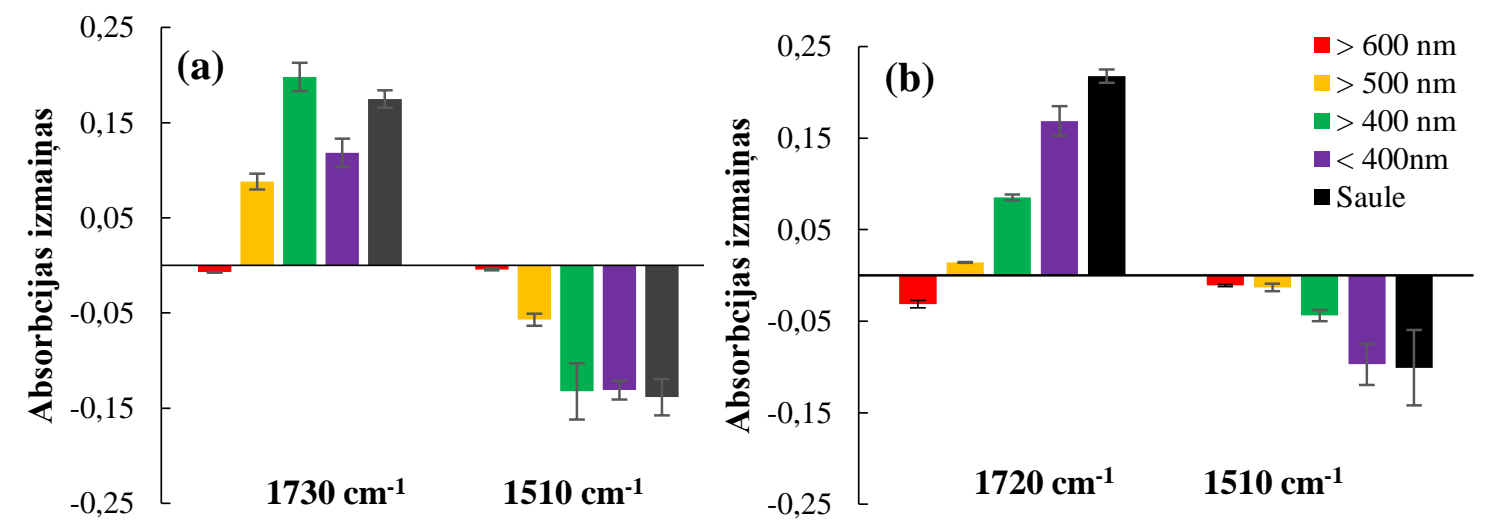

\subsection{3. att. Termiski modificētas $\left(170^{\circ} \mathrm{C}\right)$ (a) un nemodificētas (b) apses koksnes absorbcijas izmaiṇas ( \pm standartnovirze) viḷnu skaițu $1510 \mathrm{~cm}^{-1}$ un $1720 \mathrm{~cm}^{-1}$ apgabalos dažādu saules starojuma spektru apgabalu iedarbības rezultātā.}

Toties apgabalā ap $1720 \mathrm{~cm}^{-1}$ lielākas ḳ̂miskā izmaiṇas termiski modificētai koksnei izraisa saules starojuma apgabals ar viḷnu garumu $>400 \mathrm{~nm}$. Arī starojums ar viḷnu garumu > $500 \mathrm{~nm}$ izraisa ievērojamas termiski modificētas koksnes virsmas ķīmiskās izmaiņas. Nemodificētai koksnei nelielas ķīmiskās izmaiņas izraisa starojums ar viḷnu garumu $>400 \mathrm{~nm}$, bet starojums ar viḷnu garumu > $500 \mathrm{~nm}$ vairs vērā ṇemamas, ar FTIR konstatējamas, ķīmiskās izmaiņas neizraisa.

Starojuma izraisītas termiski modificētas koksnes ķīmiskās pārvērtības norit diezgan strauji. Testā, kurā termiski modificēta apses koksne mākslīgās novecināšanas kamerā 500 stundas tika pakḷauta UV starojumam, jau pēc 10 apstarošanas stundām absorbcijas izmaiṇas bija sasniegušas 75 \% no kopējām absorbcijas izmain̄ām, kādas tika fiksētas testa beigās, un pēc 200 stunām absorbcijas izmaiņas vairs nemainījās (3.44. att.). Abu raksturīgo absorbcijas spektra apgabalu izmaiņas noritēja apmēram līdzīgi.

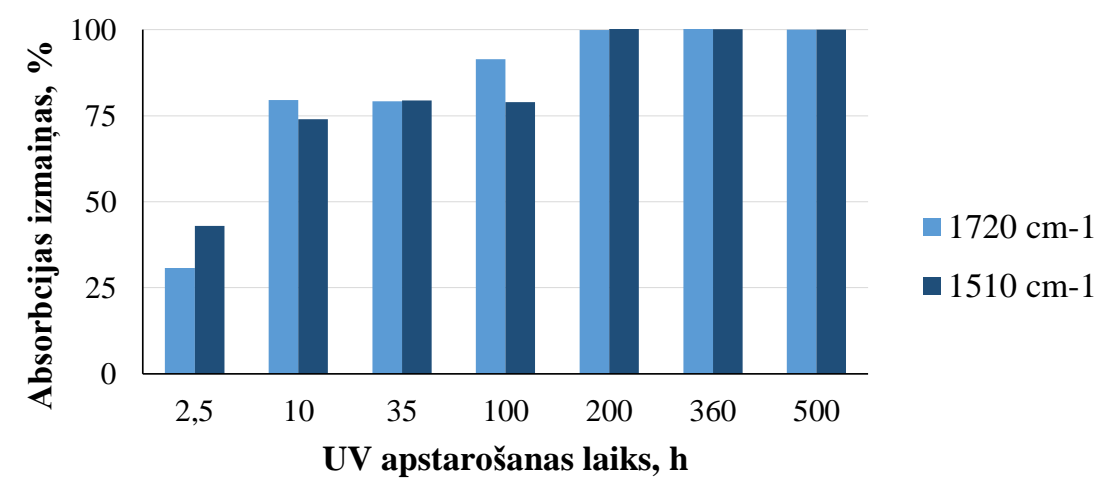

3.44. att. Termiski modificētas $\left(\mathbf{1 7 0}^{\circ} \mathrm{C}\right)$ apses koksnes absorbcijas izmainuu dinamikas viḷnu skaiḷu $1510 \mathrm{~cm}^{-1}$ un $1720 \mathrm{~cm}^{-1}$ apgabalos koksnes apstarošanas laikā ar UV starojumu mākslīgās novecināšanas kamerā. 
Daudzos koksnes novecošanās procesu pētījumos ir konstatēta korelācija starp koksnes krāsas izmaiṇām un izmain̄ām FTIR absorbcijas spektros (Pandey, 2005b; Wang and Ren, 2008; Rosu et al., 2010). Salīdzinot dažādu saules starojuma spektra apgabalu izraisītās krāsu izmainas $\Delta \mathrm{Eab}$ ar absorbcijas izmain̄ām pie viḷnu skaitliem 1510 un $1720 \mathrm{~cm}^{-1}$, nemodificētai koksnei starp šiem lielumiem pastāv cieša korelācija korelācijas koeficienti virs 0.9. Savukārt termiski modificētai koksnei korelācija nav cieša (3.41. att.).
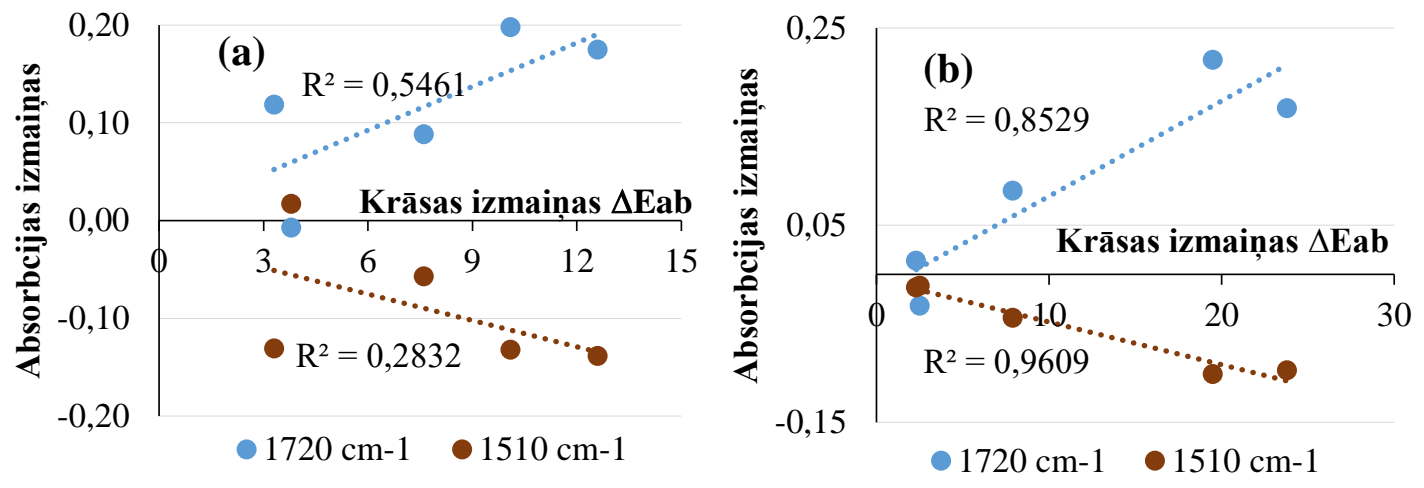

\subsection{5. att. Korelācija starp koksnes krāsas un ḳīmiskajām izmaiṇām, koksni} paḳ̣aujot dažādu saules spektra starojumu apgabaliem: (a) termiski modificēta $\left(170^{\circ} \mathrm{C}\right)$ apse; (b) nemodificēta apse.

Pētījumos ir konstatēts, ka liela daḷa starojuma izraisītās ķīmiskajās reakcijās radušos vielu ir savienojumi, kas ar ūdeni no koksnes virsmas izskalojas (Temiz et al., 2007; Huang et al., 2012a). 3.46. attēlā ir parādītas termiski modificētas koksnes FTIR absorbcijas spektra izmaiņas, koksni 1000 stundas apstarojot ar UV starojumu mākslīgās novecināšanas kamerā un tālākajā eksperimenta gaitā paraugus pakḷaujot intensīvai apsmidzināšanai ar ūdeni, kuras laikā šķ̄istošie fotodegradācijas produkti tika no koksnes virsmas noskaloti. Kā redzams, jau pirmajās trijās noskalošanas stundās lielākā daḷa apstarošanas laikā radušos savienojumu, kas absorbcijas spektra izmaiņās parādās kā absorbcijas pieaugums (brūnā līnija), bija izskalojušies, attiecīgi absorbcijas izmaiņu spektrā parādoties kā absorbcijas samazinājumam (zilās līnijas).

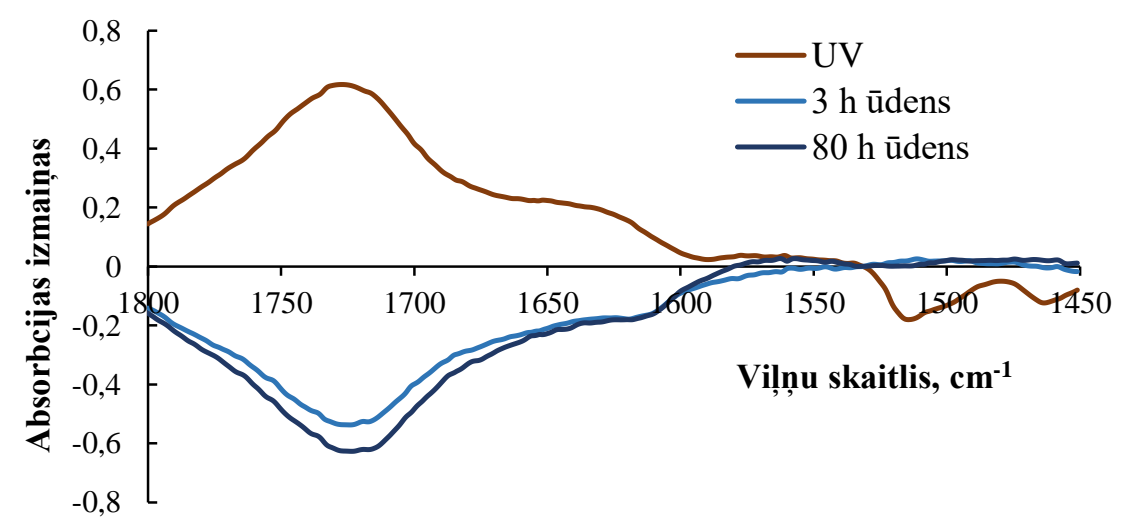

3.46. att. Termiski modificētas $\left(\mathbf{1 7 0}^{\circ} \mathrm{C}\right)$ apses koksnes virsmas absorbcijas izmaiṇas pēc 1000 stundu apstarošanas ar UV starojumu un tai sekojošas virsmas apsmidzināšanas ar ūdeni. 
Nemodificētai un termiski modificētai koksnei pirms un pēc mākslīgās pilna cikla (PC) novecināšanas tika noteikts elementsastāvs. Vairāk nekā $90 \%$ no koksnes elementsastāva sastāda ogleklis (C) un skābeklis (O), un par koksnes izmaiņu ķīmisko raksturu zināmā mērā var spriest pēc šo elementu procentuālā satura attiecību $(O / C)$ izmaiṇām koksnē. 3.5. tabulā ir parādītas $(\mathrm{O} / \mathrm{C})$ attiecības koksnē pirms un pēc mākslīgās PC novecināšanas.

\section{5.tabula}

\section{Nemodificētas un termiski modificētas apses un baltalkšņa koksnes $\mathrm{O} / \mathrm{C}$ attiecība} pirms un pēc mākslīgās PC novecināšanas

\begin{tabular}{lllc}
\hline \multicolumn{2}{c}{ Koksne } & O/C pirms novecināšanas & O/C pēc novecināšanas \\
\hline \multirow{3}{*}{ Apse } & nemodificēta & $0.94(0.02)$ & $1.20(0.01)$ \\
\cline { 2 - 4 } & $160^{\circ} \mathrm{C}$ & $0.93(0.01)$ & $1.13(0.02)$ \\
\cline { 2 - 4 } & $170^{\circ} \mathrm{C}$ & $0.85(0.02)$ & $1.10(0.02)$ \\
\hline \multirow{3}{*}{ Baltalksnis } & nemodificēta & $0.91(0.02)$ & $1.16(0.02)$ \\
\cline { 2 - 4 } & $160^{\circ} \mathrm{C}$ & $0.85(0.02)$ & $1.07(0.02)$ \\
\cline { 2 - 4 } & $170^{\circ} \mathrm{C}$ & $0.83(0.02)$ & $1.06(0.02)$ \\
\hline
\end{tabular}

Iekavās uzrādītas standartnovirzes

Līdzīgas koksnes elementsastāva izmainas pēc PC novecināšanas ir gan nemodificētai, gan termisko modificētai apses un baltalkšņa koksnei. Visos analizētajos gadījumos pēc novecināšanas $\mathrm{O} / \mathrm{C}$ attiecība ir ievērojami palielinājusies, kas parāda, ka koksnes virsmā ir palielinājies skābekḷa īpatsvars. Tas tiek saistīts ar lignīna, kuram raksturīga relatīvi zema $\mathrm{O} / \mathrm{C}$ attiecība, degradāciju un izskalošanos no koksnes virsmas un koksnes virsmas bagātināšanos ar celulozi (Hon and Chang, 1984; Feist 1990a).

\subsubsection{Virsmas mikrostruktūras izmaiṇas}

Novecošanās laikā mainās arī koksnes virsmas struktūra. Sākotnējās izmaiṇas ir mikrostruktūras līmen̄i. Tādēl, lai izsekotu koksnes mikrostruktūras izmain,ām, tika izmantota elektronu skenējošā mikroskopija (SEM) (3.47. att.).
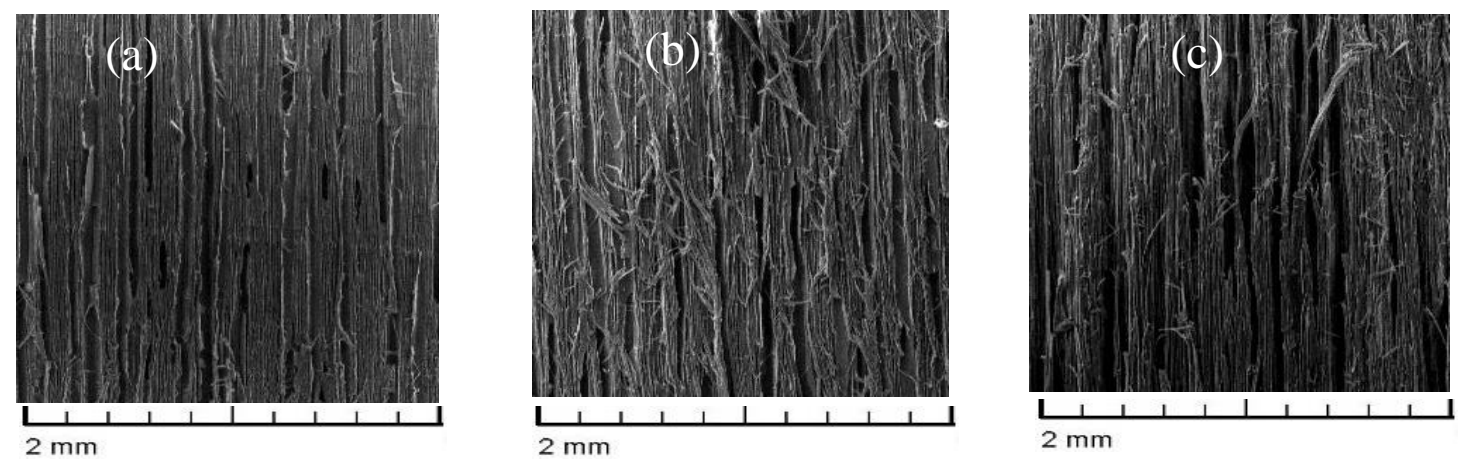

3.47. att. Termiski modificētas apses koksnes virsmas SEM attēli pirms mākslīgās novecināšanas (a), pēc 720 stundu apstarošanas ar UV starojumu (b) un pēc 1000 h PC novecināšanas (c).

Mikroskopijai paredzētie paraugi tika sagatavoti no novecināšanai paredzētajiem dēliem, un, lai rezultāti būtu salīdzināmi, paraugi abiem novecināšanas režīmiem tika 
sagatavoti no viena dēḷa. Dēḷ mehāniskās apstrādes rezultātā atsevišḳas virsējās šḳiedras ir bojātas, bet visumā virsma pirms novecināšanas ir gluda un nav redzami termiskās modifikācijas procesā radušies koksnes trauku sieniņu poru bojājumi (3.48. att.).
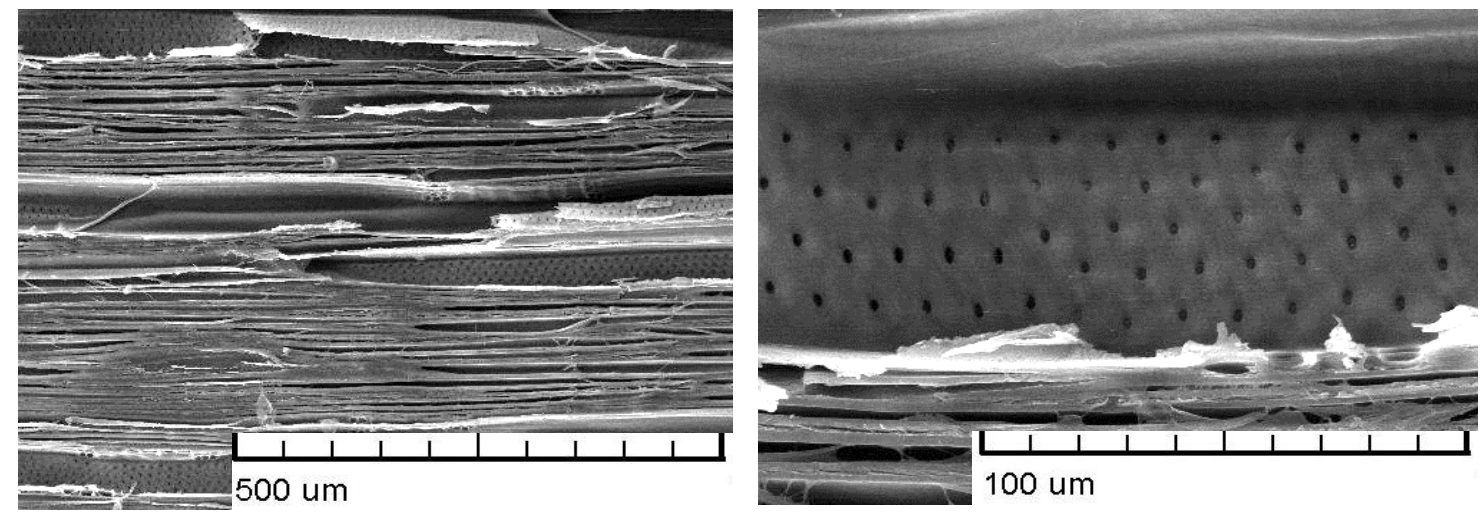

\subsection{8. att. Termiski modificētas $\left(\mathbf{1 7 0}^{\circ} \mathrm{C}\right)$ apses koksnes virsmas SEM attēli pie dažādiem palielinājumiem pirms tās mākslīgās novecināšanas.}

Pēc koksnes 720 stundu eksponēšanas UV starojumam, koksnes virsmā var redzēt daudz daḷēji atdalījušos šķiedru (3.49. att.). Tam iemesls, acīmredzot, ir lignīna degradācija. Lignīns sastāda lielāko daḷu starpšūnu vielas, kura lielā mērā nodrošina koksnes virsmas integritāti (Fujita and Harada, 2000). Lignīnam degradējoties, starpšūnu saistība vājinās, un virsējās škiiedras atdalās no koksnes matricas. Līdzīga koksnes virsmas šķiedru atdalīšanās UV starojuma iedarbības rezultātā ir novērota arī pētījumā par nemodificētas koksnes novecošanos (Derbyshire and Miller, 1981). SEM attēlā ir arī redzams, ka UV iedarbības rezultātā koksnes trauku sieniņās pie porām sāk veidoties plaisas (3.49. att.).
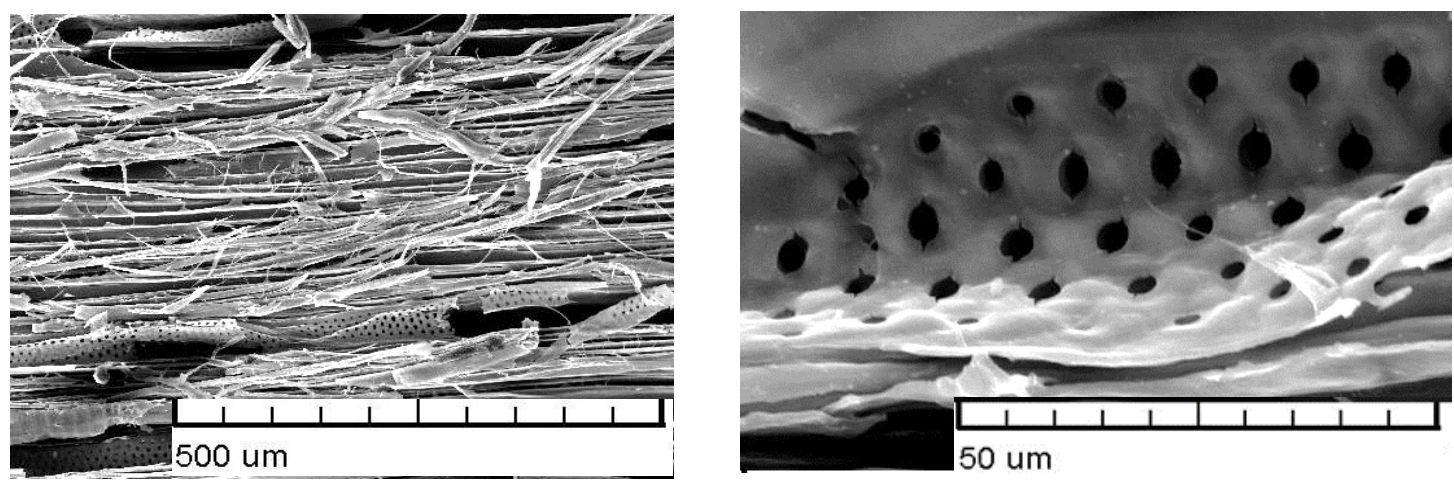

\subsection{9. att. Termiski modificēta $\left(\mathbf{1 7 0}^{\circ} \mathbf{C}\right)$ apses koksnes SEM attēli pie dažādiem palielinājumiem pēc paraugu 720 stundu apstarošanas ar UV starojumu.}

Paraugu virsmā, kuri tika pakḷauti pārmaiṇus UV apstarošanai un apsmidzināšanai ar ūdeni, ir mazāk daļēji atdalījušos šḳiedru, jo ūdens veicina to pilnīgu atdalīšanos un noskalošanos (3.50. att.). 

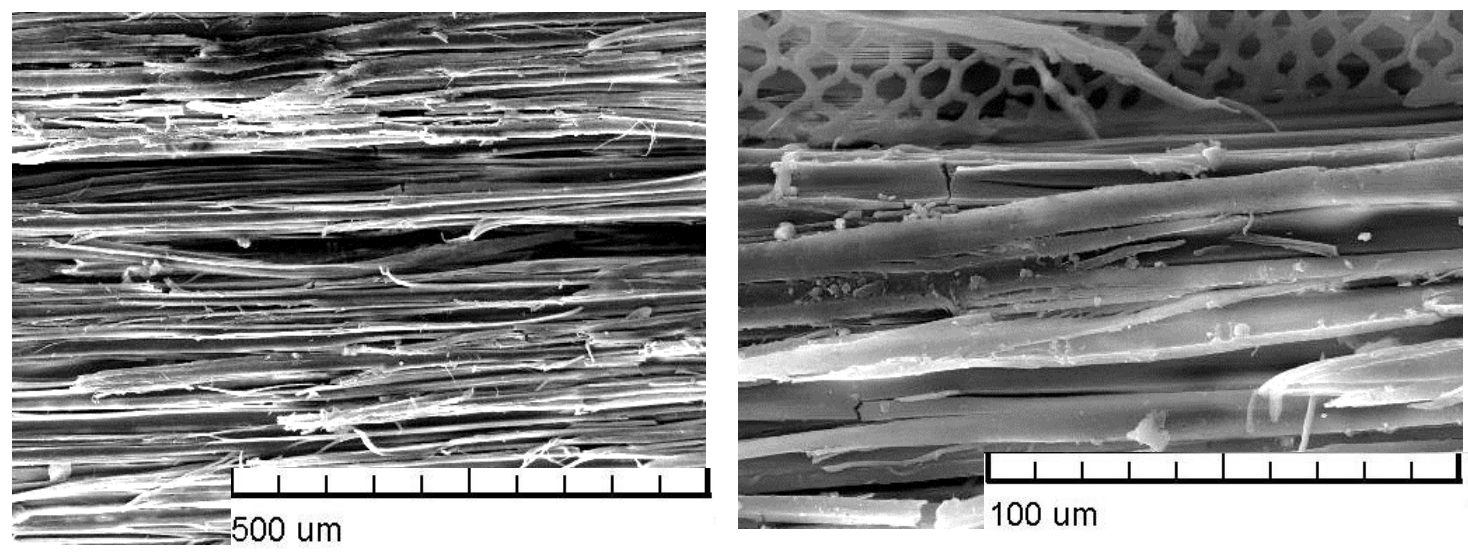

\subsection{0. att. Termiski modificētas $\left(1^{\circ}{ }^{\circ} \mathrm{C}\right)$ apses koksnes SEM attēli pie dažādiem palielinājumiem pēc 1000 stundām pilnas mākslīgās novecināšanas (UV apstarošana un noskalošana ar ūdeni).}

Tēdejādi kompleksas UV starojuma un ūdens iedarbības rezultātā koksnes virsma kḷūst gludāka, nekā koksni pakḷaujot tikai UV apstarošanai. Šis novērojums ir līdzīgs aprakstītajam par nemodificētas koksnes strukturālajām izmaināām dažādu vides faktoru ietekmē (Temiz et al., 2005). Toties kombinētas UV un ūdens iedarbības rezultātā stipri degradējas koksnes trauku sieniņas (3.50. att.), kuras, plaisām ap porām izplešoties, ir pārvērtušās sietveida struktūrā. Tāpat ir labi saskatāmas šḳērsplaisas koksnes šķiedru sieniņās. Tas viennozīmīgi parāda, ka ūdens iedarbība ir būtisks faktors un ievērojami veicina termiski modificētas koksnes struktūras degradāciju novecošanās procesā.

Pētījumos par termiski modificētas koksnes stabilitāti pret vides faktoru iedarbību ir noskaidrots, ka:

- neatkarīgi no modifikācijas temperatūras, termiski modificētas apses un baltalkšņa koksnes krāsa ir stabila, ja tā nav pakḷauta gaismas ietekmei, bet starojuma spektra redzamās gaismas apgabals veicina krāsas izmaiṇas;

- saules starojuma izraisītas izmaiņas koksnes hromoforo grupu sistēmā būtiski atšķiras nemodificētai un termiski modificētai koksnei;

- gan pilns saules, gan UV starojums termiski modificētai koksnei, salīdzinot ar nemodificētu koksni, izraisa mazāka apjoma krāsas izmaiṇas;

- nav būtisku atšķirīibu starp termiski modificētas apses un baltalkšņa koksnes, kā arī starp dažādās temperatūrās modificētas apses koksnes krāsas izmaiṇām saules starojuma ietekmē;

- termiski modificēta koksne, salīdzinot ar nemodificētu koksni, ir jutīgāka pret starojumu ar garāku viḷnu garumu un tai būtiskas gan krāsas, gan ķīmiskās izmaiņas izraisa arī starojums ar viļ̣nu garumu virs $600 \mathrm{~nm}$. Toties UV starojums termiski modificētu koksni ietekmē relatīvi mazāk;

- kompleksas saules starojuma un ūdens iedarbības rezultātā gan TM, gan nemodificēta koksne zaudē krāsainību un kḷūst pelēkas, kas ir saistīts ar fotodegradācijas produktu vieglo izskalošanos no koksnes;

- UV starojuma un ūdens iedarbības rezultātā termiski modificētas koksnes anatomiskie struktūrelementi tiek degradēti un koksne zaudē savu virsmas integritāti;

- sie secinājumi ir būtiski, veidojot pārklājumus termiski modificētas koksnes dekoratīvo īpašību saglabāšanai gan iekštelpās, gan āra vidē. 


\subsection{Termiski modificētai koksnei piemērota pārklājuma sastāva izveidošana}

Koksnes pasargāšanai pret vides faktoru izraisītu novecošanos lieto pārklājumus. Situācijās, kad, lietojot termiski modificētu koksni, tai ir paredzēta arī dekoratīva funkcija, svarīgi koksnes aizsardzībai izvēlēties pārklājumu, kas pēc iespējas mazāk mainītu tās termiskās modifikācijas procesā veidojušos izskatu. Šajā darbā, lai maksimāli saglabātu koksnes dekorativitāti, tās aizsardzība tika realizēta ar plēvi neveidojošiem pārklājumiem, par kādiem tiek uzskatīti pārklājumi, kuri virs koksnes virsmas neveido par pieciem mikroniem biezāku plēvi (3.51.att.).
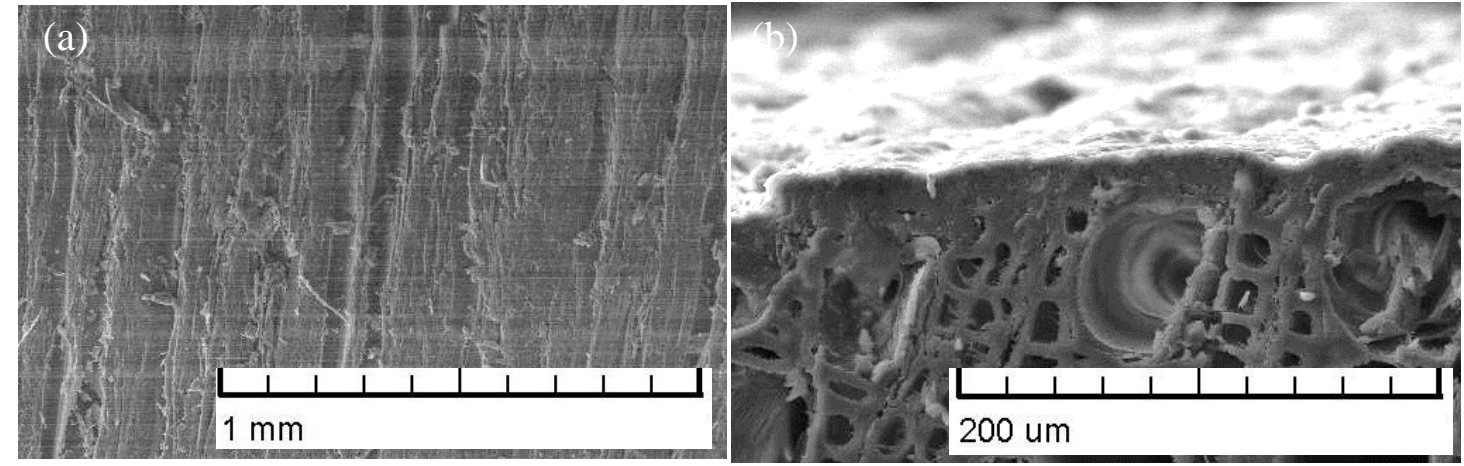

3.51. att. Termiski modificēta koksne ar plēvi neveidojošu pārklājumu SEM attēli: (a) virsskats; (b) šḳērsgriezums.

Plēvi neveidojošu pārklājumu priekšrocība ir to spēja nodrošināt koksnes dabīgā izskata saglabāšanos, tie ekspluatācijas laikā nelobās un ir viegli atjaunojami. Būtisks plēvi neveidojošie pārklājumu trūkums, lietojot tos koksnes aizsardzībai āra apstākḷos, ir tas, ka tie nav ilglaicīgi noturīgi tādēl salīdzinoši bieži ir jāatjauno.

Koksnes pārklājumiem ir divas galvenās funkcijas - ierobežot mitruma iekḷūšanu koksnē un pasargāt koksni no saules starojuma degradējošās iedarbības, tā nodrošinot koksnes dekorativitātes saglabāšanu tās ekspluatācijas laikā. Pārklājuma spēju regulēt mitruma plūsmu galvenokārt nosaka izmantotās saistvielas.

\subsubsection{Saistvielas}

Pamatojoties uz literatūras analīzi, kā piemērotākā pārklājuma grupa tika izvēēèta alkīda sveḳu pārklājumi uz šḳīdinātāja bāzes. Pētījumā eksperimentālo pārklājuma sastāvu pagatavošanai tika izmantoti rūpnieciski alkīda sveķi ar dažādu ellıas saturu tajos un linsēklu eḷıa. Linsēklu eḷlas kā saistvielas izmantošanai pārklājumos ir virkne priekšrocību. Tā ir dabīgs, atjaunojams resurss, un daļas alkīda sveķu aizstāšana ar ellıu padara pārklājumu videi draudzīgāku. Turklāt linsēklu eḷıas iekḷaušana pārklājuma sastāvā ir arī ekonomiski izdevīga, jo alkīda sveķi ir ievērojami dārgāki. Linsēklu elı̣a arī uzlabo pārklājuma elastību, kas koksnei paredzētos pārklājumos ir l̦oti svarīgi. Taču linsēklu eḷıa palielina pārklājuma ūdens caurlaidību, kas ir viens no sistēmas koksnepārklājums stabilitātes noteikšanas kritērijiem. 
Lai noskaidrotu, vai ir iespējams pārklājumā, kas tiek lietots termiski modificētai koksnei, daļu alkīda sveķu aizstāt ar linsēklu eḷ,u, nodrošinot pietiekoši zemu ūdens caurlaidību, eksperimentālā pārklājuma sastāvā kā saistviela tika izmantoti alkīda sveķi un linsēklu ellıa svara attiecībās $2: 1$. Šì , kā iespējami optimālā, attiecība tika noskaidrota priekšmēǵinājumos. Salīdzināšanai tika izmantoti atbilstošas klases dažādu ražotāju (Tikkurila, Akzo Nobel, Caparol, Rīgas Laku un Krāsu Rūpnīca) rūpnieciski produkti. Visi pārklājumi bija ar līdzīgu nosacīto viskozitāti (pārklājuma iztecēšanas laiks, kas noteikts, lietojot Ford kausa veida viskozimetru) un blīvumu no $0.80 \mathrm{lī} \mathrm{dz} 0.85 \mathrm{~g} \mathrm{~cm}^{-3}$.

Lai ūdens varētu iekḷūt pārklājumā un tālāk aizsniegt koksni, tam ir jāspēj izveidot pietiekoši lielu saskares virsmu ar pārklājumu. Augsta pārklājuma hidrofobitāte, ko var izmērīt kā virsmas slapināšanas leņķi, norāda uz tā spēju mazināt potenciālo iekḷūšanu koksnē. Virsmas slapināšanas leṇķi, kas noteikti piecas sekundes pēc ūdens piliena uzpilināšanas, rūpnieciskajiem un eksperimentālajam sastāvam ar alkīda sveķu-lineḷıas saistvielu ir parādīti 3.52. attēlā.

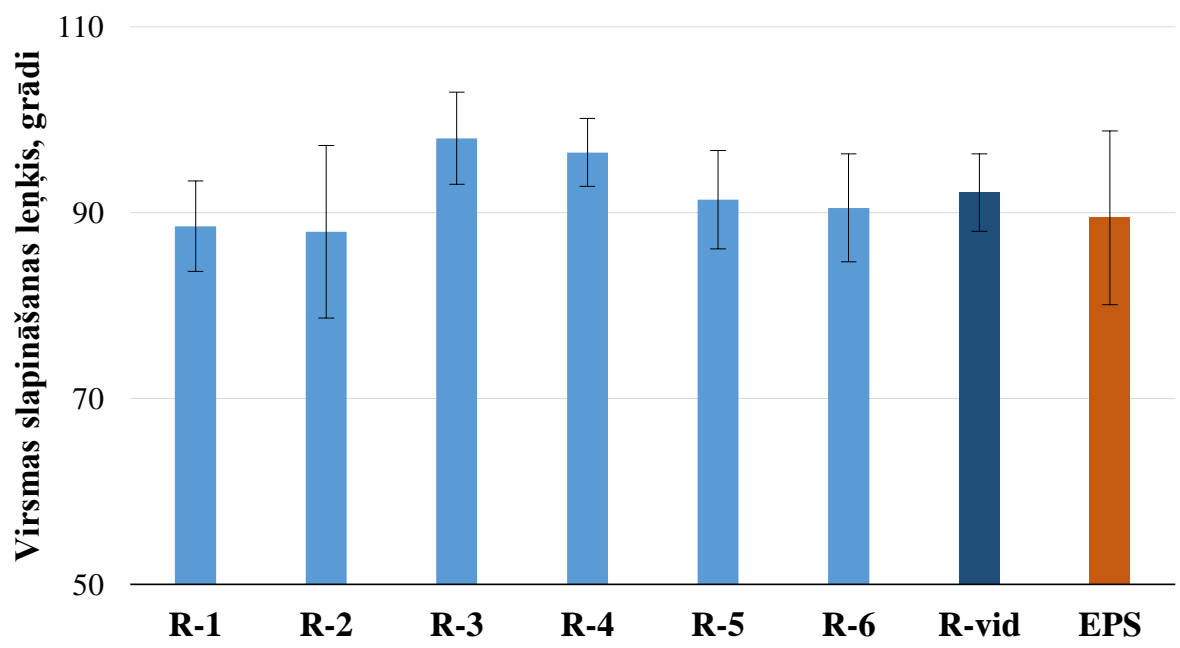

\subsection{2. att. Virsmas slapināšanas leņķis ( \pm standartnovirze) piecas sekundes pēc ūdens piliena uzpilināšanas dažādiem pārklājumiem.}

Apzīmējumi: R - rūpniecisks pārklājums; EPS - eksperimentālais pārklājums.

Eksperimentālā pārklājuma slapināšanas leṇksa vidējā vērtība bija nedaudz mazāka par rūpniecisko pārklājumu vidējo vērtību. Tomēr, ņemot vērā relatīvi lielo rezultātu izkliedi, ko varētu būt ietekmējis koksnei raksturīgais virsmas mikroraupjums, atšķirības starp visu analizēto pārklājumu slapināšanas leņķiem nav būtiskas ( $\mathrm{p}>0.05)$. Šie rezultāti parāda, ka rūpnieciskajiem un eksperimentālajam pārklājumam, kura sastāvā ir iekḷauta linsēklu eḷla, hidrofofitāte ir līdzīga.

Lai noteiktu pārklājuma spēju pasargāt koksni no tiešas ūdens iedarbības, tika veikta pārbaude saskaṇā ar standartu LVS EN 927-5:2007. Tas paredz iepriekš pēc noteiktām prasībām sagatavotu paraugu virsmas iemērkšanu ūden̄i uz 72 stundām un parauga masas pieauguma kontroli. Parauga uzn,emto üdens daudzumu nosaka ne tikai pārklājuma, bet arī koksnes substrāta un ūdens mijiedarbība. Līdz ar to, galarezultāts ir tieši atkarīgs no kopējās <koksne-pārklājums> sistēmas. Standarts LVS EN 927-2:2015 paredz, ka par stabilu var uzskatît sistēmu, kura nodrošina, lai tās ūdens caurlaidība nebūtu lielāka par $175 \mathrm{~g} \mathrm{~m}^{-2}$ (melnā līnija 3.53. att.), bet par daḷēji stabilu, ja caurlaidība 
ir mazāka par $250 \mathrm{~g} \mathrm{~m}^{-2}$ (sarkanā līnija 3.53. att.). Tikai puse no pārbaudītajiem rūpnieciskajiem pārklājumiem uz nemodificētas koksnes, ja pārklājums tiek lietots tādā apjomā, lai uz koksnes virsmas neveidotos redzama plēve, var nodrošināt pret ūdeni daḷēji stabilu <koksne-ūdens> sistēmu (3.53. att.). Arī eksperimentālais sastāvs ar nemodificētu koksni nenodrošina stabilu sistēmu, un tā caurlaistais ūdens daudzums ir lielāks par rūpniecisko sastāvu vidējo rādītāju.

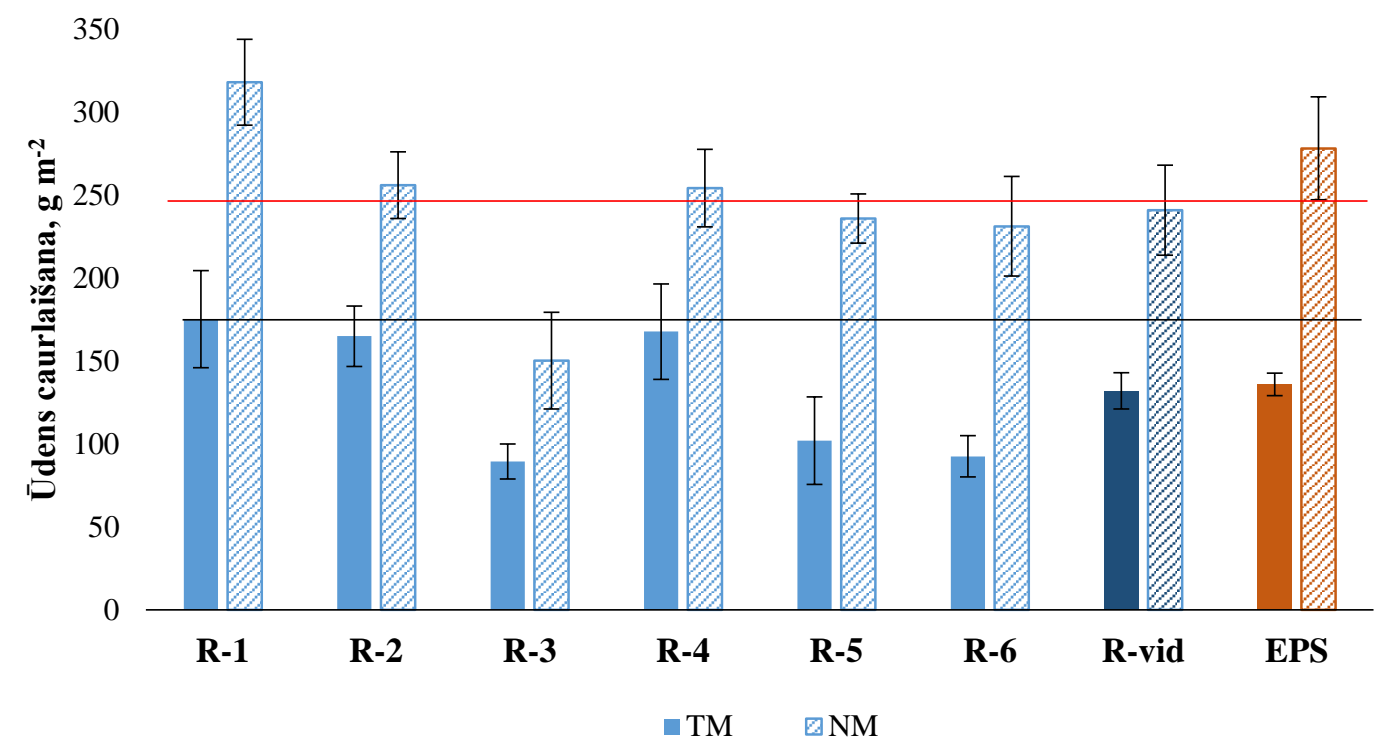

\subsection{3. att. Uz nemodificētas (NM) un termiski modificētas (TM) apses koksnes lietotu dažādu rūpniecisko un eksperimentālā pārklājuma ūdens caurlaidība ( \pm standartnovirzes). \\ Apzīmējumi: R - rūpniecisks pārklājums; EPS - eksperimentālais pārklājums.}

Ar termiski modificētu koksni gandrīz visi sastāvi veido pret tiešu ūdens iedarbību stabilu sistēmu. Arī uz termiski modificētas koksnes lietots eksperimentālais pārklājums nodrošina pret tiešu ūdens iedarbību stabilu sistēmu, un ūdens caurlaidības rādītājs eksperimentālajam pārklājumam ir līdzīgs rūpniecisko pārklājumu vidējam rādītājam. Šie rezultāti liecina, ka pārklājums, kurā daḷa alkīda sveḳu ir aizstāti ar linsēklu ellıu pietiekošā līmenī aizkavē tiešu ūdens iekḷūšanu termiski modificētā koksnē.

Pārklājumam ne tikai jāaizkavē ūdens iekḷūšanu koksnē, bet arī jānodrošina pietiekoši ātra koksnē nonākušā ūdens izkḷūšana no tās. Par pārklājuma efektivitāti šajā aspektā liecina caurlaidības testā uzṇemtā ūdens masas samazināšanās paraugiem 42 dienas atrodoties standarta apstākḷos $\left(20^{\circ} \mathrm{C} ; 65 \% \mathrm{RH}\right)(3.54$. att.). 


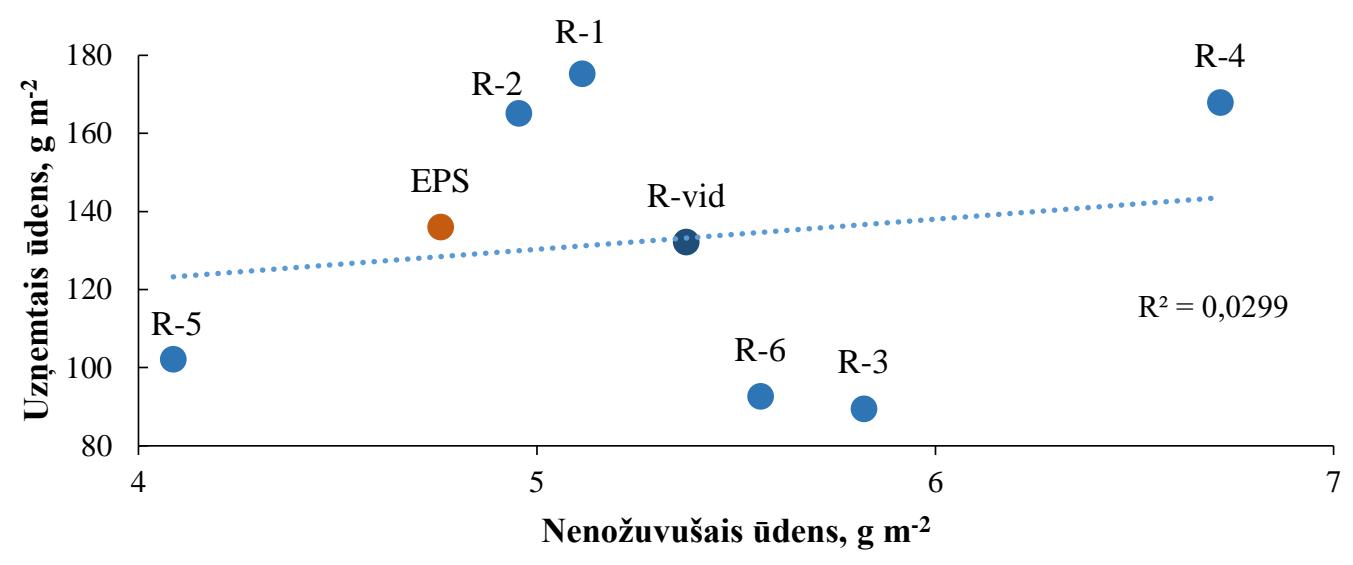

3.54. att. Termiski modificētas koksnes ar dažādiem pārklājumiem ūdens caurlaidības testā uzņemtais un 42 dienu laikā nenožuvušais ūdens daudzums. Apzīmējumi: R - rūpnieciskie pārklājumi; EPS - eksperimentālais pārklājums.

Redzams, ka nepastāv korelācija starp pārklājumu spēju aizsargāt termiski modificētu koksni no ūdens uzṇemšanas, atrodoties tiešā kontaktā ar to, un nodrošināt efektīvu uzṇemtā ūdens aizvadīšanu no koksnes. Ar eksperimentālo sastāvu pārklāta termiski modificēta koksne, atrodoties tiešā kontaktā, uzņem pat par 50\% vairāk ūdeni nekā daži pārbaudītie rūpnieciskie pārklājumi. Toties, salīdzinot ar eksperimentālo pārklājumu, tikai viens no rūpnieciskajiem pārklājumiem (R-5) rekondicionēšanas fāzē nodrošina pilnīgāku uzņemtā ūdens masas samazināšanos paraugos. Savukārt rūpnieciskais pārklājums (R-3), kurš vislabāk pasargāja termiski modificētu koksni no ūdens uzṇemšanas, nožǔšanas procesā relatîvi slikti nodrošināja uzṇemtā ūdens aizvadīšanu.

Bieži pārklājumos izmanto daḷēji polimerizētu linsēklu eḷıu jeb pernicu. Pernica padara pārklājumu cietāku, bet vienlaikus mazina tā elastību. Āra testā tika pārbaudīti pārklājumu sastāvi, kuros bez alkīda sveķiem bija iekḷauta linsēklu eḷ,a vai pernica. Daḷai pārklājumu tika pievienoti dzelzs oksīda pigmenti divās dažādās masu attiecībās pret saistvielu - 18\% un 30\%. Plaisas tika novērtētas mikroskopiski un vizuāli (2.2. tab.) Četru vērtēšanas reižu (pēc 35, 75, 110 un 145 ekspozīcijas dienām) rezultātu summārās vērtības katrai pārklājumu sērijai ir parādītas 3.55. attēlā.

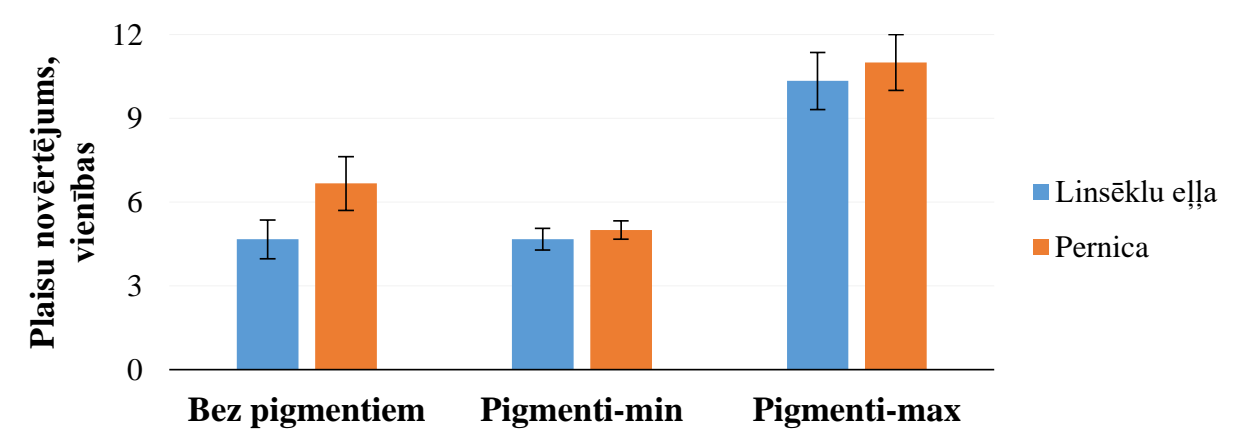

3.55. att. Plaisu vizuālā novērtējuma summārās vērtības ( \pm standartnovirzes) termiski modificētai $\left(170^{\circ} \mathrm{C}\right)$ apses koksnei āra ekspozīijas laikā. 
Lai arī statistiski būtiskas $(\mathrm{p}<0.05)$ atšķirības starp linsēklu eḷlas un pernicas iekḷaušanu sastāvā tika novērotas vienīgi bezpigmentu pārklājumiem, tomēr arī pigmentētējiem pārklājumiem intensīvāka plaisu veidošanās tendence ir vērojama paraugiem, kuru pārklājumos daḷa no saistvielas ir pernica. Kontroles reizē pēc 175 dienām vairs nebija atšķirības starp pārklājumiem ar dažādu saistvielu sastāvu, jo visiem paraugiem bija ar aci saskatāmas plaisas.

Savukārt šajā eksperimentā novērotā krāsas izmaiṇu tendence ir atšķirīga. Sākuma posmā vidējās krāsas izmaiņas paraugiem ar abu veidu pārklājumiem bija nebūtiskas ( $\mathrm{p}>0.05)$, bet, pieaugot ekspozīcijas laikam, krāsa mainījās mazāk paraugiem, kuru pārklājumā bija pernica (3.56. att.).

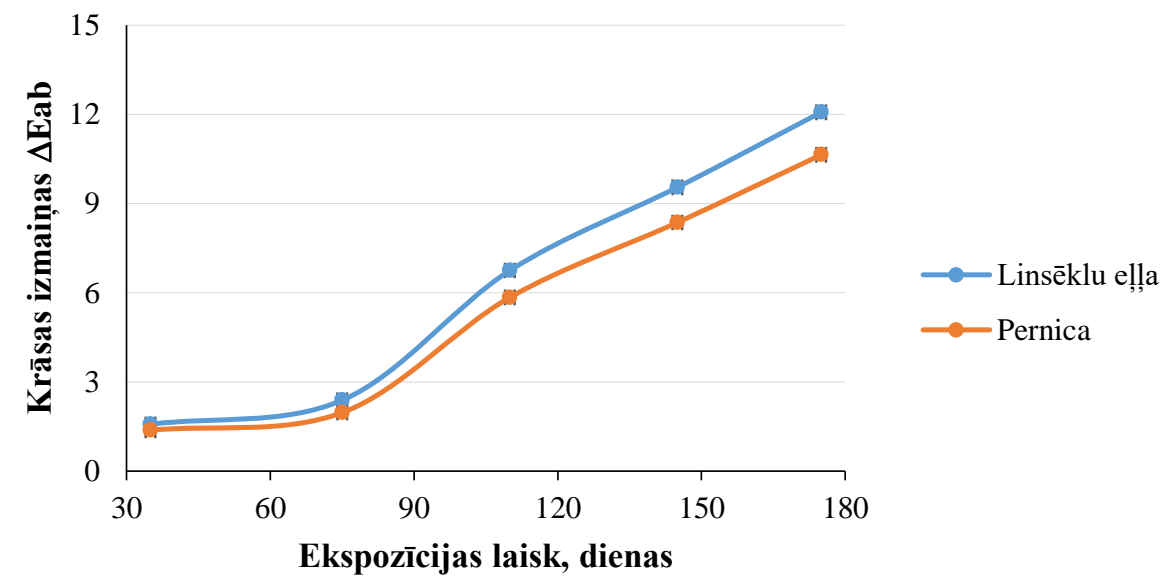

\subsection{6. att. Termiski modificētas $\left(\mathbf{1 7 0}^{\circ} \mathrm{C}\right)$ apses koksnes krāsas izmaiṇas āra testā, pārklājumā izmantojot linsēklu eḷı un pernicu.}

Šie rezultāti parāda, ka, lai arī pārklājumiem ar pernicu ir nedaudz vājāka rezistence pret plaisu veidošanos, tomēr tās iekḷaušana pārklājuma sastāvā nodrošina labāku termiski modificētas koksne krāsas saglabāšanos āra apstākḷos.

Tika veikti arī testi, ar eksperimentāliem pārklājumiem, kuri atšḳīrās ar to sastāvā iekḷautajiem alkīda sveḳiem (3.6. tabula).

\section{Eksperimentālo pārklājumu saistvielu sastāvs}

3.6. tabula

\begin{tabular}{|c|c|}
\hline Eksperimentālais sastāvs EPS-1 & Eksperimentālais sastāvs EPS-2 \\
\hline Mazmolekulāri alkīda sveķi (M1) & Mazmolekulāri alkīda sveķi (M2) \\
\hline $\begin{array}{l}\text { Lielmolekulāri alkīda sveḳi uz linsēklu } \\
\text { el̦las bāzes (L1) }\end{array}$ & $\begin{array}{l}\text { Lielmolekulārs kopolimērs uz linsēklu un } \\
\text { zivju ellıas bāzes (L2) }\end{array}$ \\
\hline Linsēklu el̦la & Linsēklu el̦la \\
\hline
\end{tabular}

Nemodificēta un termiski modificēta koksne ar eksperimentālajiem sastāviem tika novecināta gan āra apstākḷlos, gan kamerā, izmantojot mākslīgās novecināšanas PC, kā arī tika pārbaudīta ūdens caurlaidība saskaņā ar standartu LVS EN 927-5. Lai iegūtos rezultātus salīdzinātu, ar EPS-2 pārklātajiem paraugiem noteiktās izmaiṇu vērtības tika 
izdalītas ar EPS-1 pārklātu paraugu izmaiņu atbilstošām vērtībām, tā iegūstot attiecību, kuras vērtība parāda, vai paraugiem ar EPS-2 pārklājumu izmaiṇas ir bijušas lielākas (attiecība > 1) vai mazākas (attiecība < 1) nekā paraugiem ar EPS-1 pārklājumu (3.57. att.).

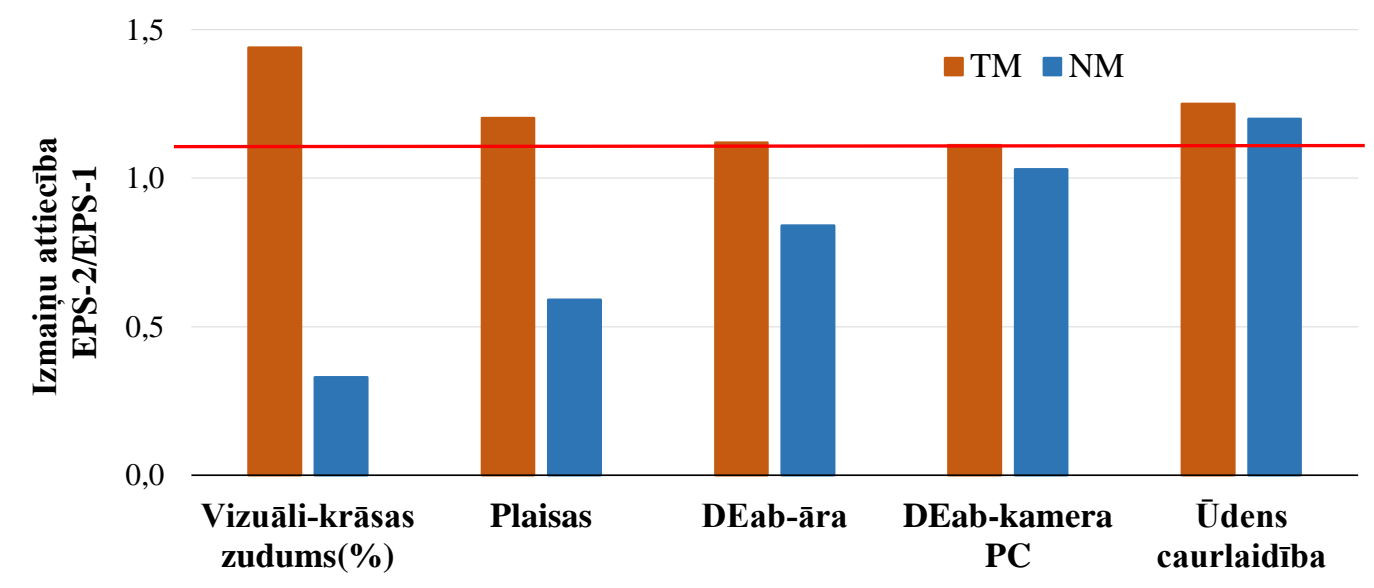

3.57. att. Attiecība (EPS-2/EPS-1) starp ar eksperimentāliem sastāviem pārklātu koksnes paraugu ūdens caurlaidības un atsevišḳu novecošanās rādītāju vērtībām. Apzīmējumi: TM - termiski modificēta koksne; NM - nemodificêta koksne.

Kā redzams no attēla, termiski modificētai koksnei visas analizētās izmaiņas ir lielākas paraugiem ar EPS-2 pārklājumu. Turklāt visos gadījumos, izņemot plaisu veidošanos, atškirības ir statistiski būtiskas $(\mathrm{p}<0.05)$. Savukārt nemodificētas koksnes gadījumā āra testā ievērojami mazākas izmaiņas ir ar EPS-2 pārklātajiem paraugiem, bet vienlaicīgi šie paraugi ir mazāk rezistenti pret tiešu ūdens iedarbību. Šie rezultāti parāda, ka liela nozīme novecošanās procesu aizkavēšanā ir optimālas sistēmas koksnepārklājums izveidošanai, un optimālais pārklājumu saistvielu sastāvs nemodificētai un termiski modificētai koksnei atškiras.

N̦emot vērā iepriekšējo eksperimentu rezultātus, tika izvēlēti gruntsslāṇa un virsslāṇa pārklājumu bāzes sastāvi, kas turpmākajos eksperimentos tika papildināti ar dažādām funkcionālām piedevām. Termiski modificētai koksnei paredzēto gruntsslāṇa un virsslāṇa pārklājumu saistvielu sastāvs un raksturojums ir dots 3.7. tabulā.

3.7. tabula.

Termiski modificētai koksnei paredzēto gruntsslāṇa un virsslāṇa pārklājumu bāzes sastāvs un raksturojums

\begin{tabular}{llcc}
\hline Komponents & \multicolumn{1}{c}{ Komponenta raksturojums } & \multicolumn{2}{c}{ Īpatsvars } \\
\cline { 3 - 4 } & & Gruntsslānis & Virsslānis \\
\hline Alkīds L1 & $\begin{array}{l}\text { Lielmolekulārs (molekulmasa 4000 } \mathrm{g} \mathrm{mol}^{-1} \text { ) } \\
\text { Eḷlas saturs - 60\% (vidēji trekns) }\end{array}$ & 0.33 & 0.50 \\
\hline Alkīds M1 & $\begin{array}{l}\text { Mazmolekulārs (molekulmasa 2000 } \mathrm{g} \mathrm{mol}^{-1} \text { ) } \\
\text { Eḷlas saturs - 80\% (trekns) }\end{array}$ & 0.33 & 0.25 \\
\hline Linsēklu eḷıa & & 0.33 & - \\
\hline Pernica & & - & 0.25 \\
\hline
\end{tabular}


Kā šḳīdinātājs gan gruntslānim, gan virsslānim tika izmantots komerciāls alifătisko (C7-C12) ogḷūdeṇražu maisījums NESSOL 220 L.

\subsubsection{Funkcionālās piedevas}

Lai pasargātu koksni no saules starojuma degradējošās iedarbības, tā nodrošinot koksnes dekorativitātes saglabāšanu ekspluatācijas laikā, koksnes pārklājumos galvenokārt tiek lietotas divu veida funkcionālās piedevas - UV absorberi un brīvo radikāḷu deaktivētāji. Koksnes aizsardzībai ir izstrādāts speciāls deaktivētājs "Lignostab", kura funkcija ir saistīties ar UV starojuma iniciētiem lignīna radikāḷiem, tā nel̦aujot tiem izraisīt ķēdes reakcijas. Šajā darbā tika pārbaudīts, cik efektīvi "Lignostab” spēj pasargāt termiski modificētu koksni no krāsas izmaiņām mākslīgās novecināšanas laikā kamerā, pakḷaujot koksni UV starojuma iedarbībai (3.58. att.).

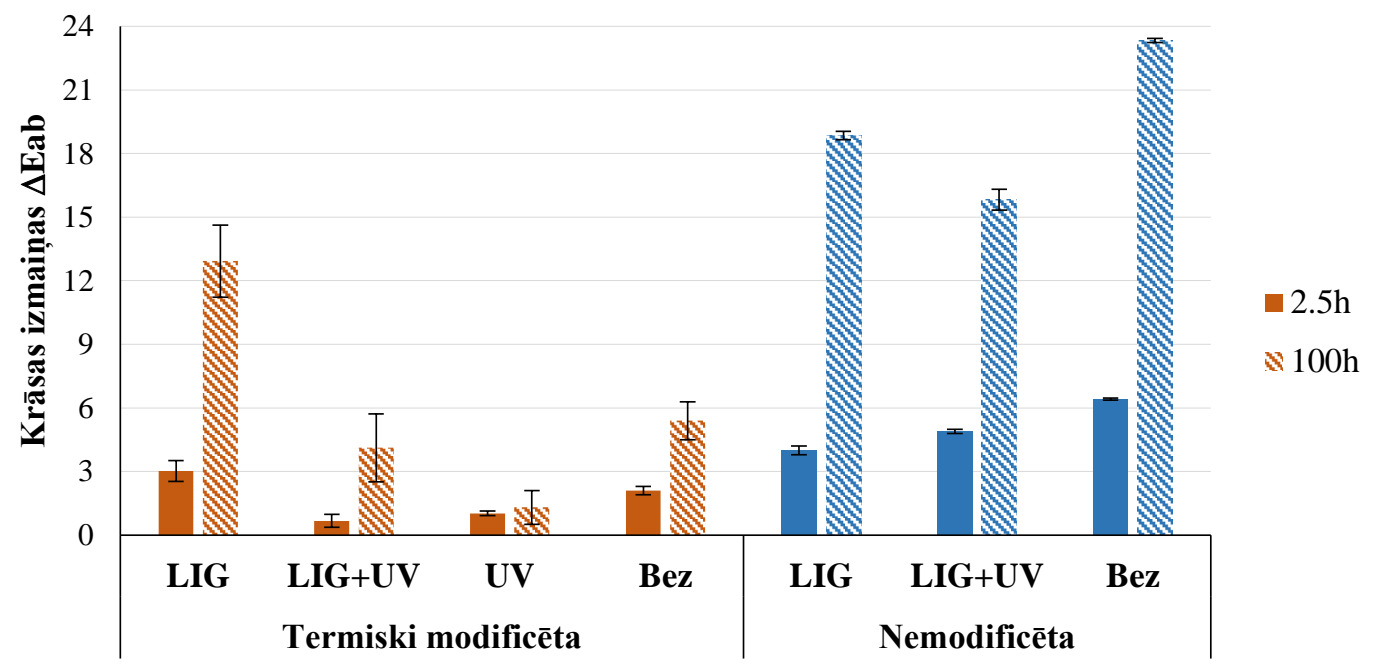

\subsection{8. att. Nemodificētas un termiski modificētas $\left(1^{\circ}{ }^{\circ} \mathrm{C}\right)$ apses koksnes ar dažādu virsmas apstrādi krāsas izmaiṇas ( \pm standartnovirze) pēc 2.5 un 100 stundu ekspozīcijas UV starojumam novecināšanas kamerā.}

Apzīmējumi: LIG - koksne apstrādāta ar "Lignostab" šķīdumu; LIG+UV - koksne apstrādāta ar "Lignostab" šķ̄idumu un pārklāta ar UV absorberi saturošu pārklājumu; UV - koksne pārklāta ar UV absorberi saturošu pārklājumu; Bez - koksne bez virsmas apstrādes

Redzams, ka nemodificētai koksnei apstrāde ar "Lignostab" šḳīdumu samazina UV starojuma izraisītas krāsas izmaiṇas. Pēc 100 stundu novecināšanas nemodificētai koksnei, kura bija apstrādāta ar "Lignostab" šķīdumu un papildus pārklāta ar UV absorberi saturošu pārklājumu, krāsas izmaiņas bija par 30\% mazākas nekā koksnei bez virsmas apstrādes. Apstrāde tikai ar Lignostab šḳīumu, lai arī samazina krāsas izmaiṇas, tomēr nav tik efektīva kā kopā ar UV starojumu absorbējošu pārklājumu, kā tas ir konstatēts arī citos pētījumos (Schaller and Rogez, 2007).

Termiski modificētai koksnei efekts ir pretējs. Jau pēc 2.5 stundu apstarošanas ar UV starojumu, ar "Lignostab" apstrādātu paraugu krāsas izmaiņas ir $3 \Delta$ Eab vienības, bet termiski modificētai koksnei bez virsmas apstrādes šāda apjoma krāsas izmaiņas tika fiksētas pēc 35 stundām. Pēc 100 ekspozīcijas stundām ar "Lignostab" apstrādātas termiski modificētas koksnes krāsas izmaiņas ir divas reizes lielākas nekā koksnei bez 
virsmas apstrādes. Termiski modificētas koksnes labāko aizsardzību pret UV starojumu šā eksperimenta ietvaros nodrošināja UV absorberi saturošs pārklājums, bet apstrāde ar "Lignostab" izrādījās krāsas izmaiṇas veicinošs faktors. Iemesls atšķirīgajam lignīna radikāḷus deaktivējošā preparāta lietošanas rezultātam uz nemodificētu un termiski modificētu koksni acīmredzot ir termiskās modifikācijas izraisītās koksnes kīimiskās struktūras izmaiņas.

Gan koksnes, gan paša pārklājuma aizsardzībai pret UV starojumu plaši lieto dažādus UV absorberus. Tās ir vielas, kas, absorbējot un pārvēršot UV starojumu mazāk enerǵētiskā starojumā (siltuma vai gaismas ar garākiem viļ̣iem), pasargā polimērmateriālus no fotodegradācijas.

N̦emot vērā, ka svarīgs pārklājumu raksturojošs parametrs ir tā stiklošanās temperatūra $T_{\mathrm{g}}$, un to būtiski var ietekmēt dažādas piedevas, tai skaitā arī UV absorberi, tika izgatavotas pārklājumu plēves ar dažādiem UV absorberiem un, izmantojot diferenciālo skenējošo kalorimetriju (DSC), noteiktas to stiklošanās temperatūras (3.8. tab.). Amorfa polimēra, kāds ir pārklājuma plēve, $T_{g}$ nav viena noteikta temperatūra, bet temperatūru intervāls. $T_{g}$ nolasīšanai no siltuma plūsmas līknes tiek lietotas vairākas metodes, kuras atšķiras ar kritērijiem, kuru punktu pieņemt par nosacīto $T_{\mathrm{g}}$. Tāpēc tabulā ir dotas pēc divām atšķirīgām siltuma plūsmas līknes interpretācijas metodēm noteiktas, atsevišķiem paraugiem ievērojami atškiirīgas, $T_{g}$ temperatūras.

3.8. tabula

Stiklošanās temperatūras $T_{g}$ pārklājumiem ar dažādiem UV absorberiem

\begin{tabular}{lcc}
\hline \multicolumn{1}{c}{ Pārklājums } & DIN 51007 & Inflection Point \\
\hline Bāze (B) & -12.7 & -14.4 \\
$\mathrm{~B}_{\mathrm{TiO}} \mathrm{TiO}$ & -6.9 & 0 \\
$\mathrm{~B}+\mathrm{ZnO}$ & -4.7 & -0.2 \\
$\mathrm{~B}+\mathrm{UVA}$ & -10.1 & -14.5 \\
$\mathrm{~B}+\mathrm{Pig} 2 \%$ & -12.1 & -12.1 \\
$\mathrm{~B}+\mathrm{Pig} 4 \%$ & -10.8 & -10.5 \\
$\mathrm{~B}+\mathrm{Pig} 6 \%$ & -10.8 & -14.5 \\
\hline
\end{tabular}

UVA - organiskais UV absorberis - komplekss preparāts, kas satur hidroksifenil-s-triazīna veida UV absorberi un brīvo radikāḷu deaktivētājs; Pig - sarkanā un dzeltenā dzelzs oksīiu maisījums

Ievērojami augstākas, pēc abiem lietotajiem paņēmieniem noteiktās, $\mathrm{T}_{\mathrm{g}}$ temperatūras, salīdzinot ar bāzes pārklājumu, ir paraugiem, kuros kā UV absorberi ir izmantoti pārklājumu rūpniecībā plaši lietoti neorganiskie absorberi - cinka oksīds ( $\mathrm{ZnO})$ un titāna dioksīds $\left(\mathrm{TiO}_{2}\right)$. Toties dzelzs oksīdi (Pig), neatkarīgi no lietotās koncentrācijas, ievērojami pārklājuma $T_{\mathrm{g}}$ nepaaugstina. Tādēḷ turpmākajos pētījumos kā UV absorberi tika izmantoti organiskais absorberis un dzelzs oksīdi.

Kameras testā tika salīdzināta divu veidu - organiskā un neorganiskāa, UV absorberu efektivitāte koksnes krāsas izmaiņu mazināšanai UV starojuma ierosinātā koksnes novecošanās procesā. Kā organiskais UV absorberis pārklājuma sastāvam tika pievienots hidroksifenil-s-triazīna (HPT) veida UV absorberis. Izmantotais 
neorganiskais absorberis bija dzelzs oksīdu maisījums, kuri absorbē ne tikai redzamās gaismas, bet arī UV starojuma viļ̧̧u apgabalā.

Termiski modificētas koksnes krāsas izmaiṇas laikā, to 1500 stundas pakḷaujot UV starojuma iedarbībai novecināšanas kamerā, atkarībā no pārklājumā lietotā UV absorbera ir parādītas 3.59. attēlā.

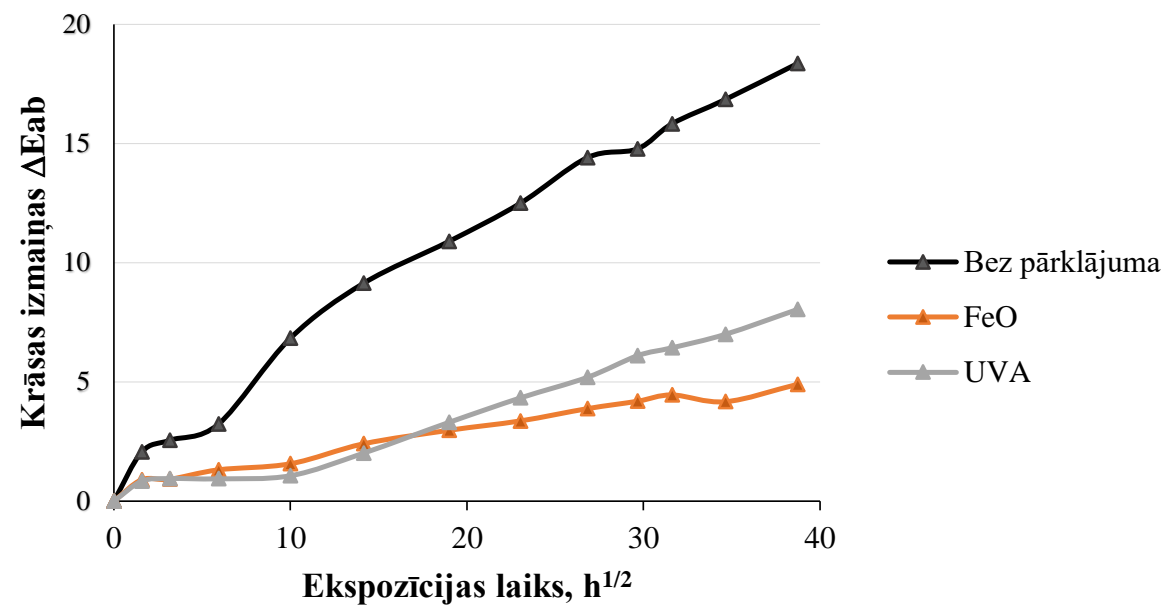

\subsection{9. att. Termiski modificētas $\left(\mathbf{1 7 0}^{\circ} \mathbf{C}\right)$ apses koksnes krāsa izmaiṇas mākslīgās novecināšanas kameras UV testa laikā.}

Abi izmantotie absorberi ievērojami palēnina UV starojuma izraisītās termiski modificētas koksnes krāsas izmaiņas, un novecināšanas sākuma posmā nav būtisku koksnes krāsas izmaiṇu atšķirības starp paraugiem ar tiem. Tomēr pēc 100 ekspozīcijas stundām ar organisko UV abosrberi saturošu pārklājumu pārklāto paraugu krāsas izmaiņas sāk straujāk pieaugt, kas varētu būt saistīts ar paša absorbera daliēju degradāciju UV starojuma ietekmē. Paraugu krāsu izmaiņu atškirīibas kḷūst būtiskas $(p<0.05)$ pēc aptuveni 700 stundu ekspozīcijas. Testa beigās paraugiem ar dzelzs oksīdus saturošo pārklājumu krāsas izmaiņas ir par 40\% zemākas nekā paraugiem ar organisko abosrberi saturošu pārklājumu. Šie rezultāti parāda, ka ilgstošā periodā dzelzs oksīda preparāti varētu nodrošināt stabilāku termiski modificētas koksnes aizsardzību pret UV starojumu. Testā gan tika pārbaudīts tikai viens organiskais UV absorberis, bet tas pārstāv UV absorberu klasi, kas no pašlaik lietotajiem ir atzīti par efektīvākajiem (Schaller et al., 2008, Özgenc et al., 2012).

Ir noskaidrots, ka termiski modificēta koksne gan bez, gan ar pārklājumu āra apstākḷlos ir pakḷauta apaugšanas riskam ar koksnes krāsojošām sēnēm (Gobakken and Lebow, 2010). Plašāk lietotie biocīdu preparāti koksnes aizsardzībai pret krāsojošām sēnēm ir propikonazols un IPBC. Laboratorijas testā saskaṇā ar standartu EN 152 tika pārbaudīta komerciāla kompleksa biocīda Wocosen 45 TK potenciālā spēja nodrošināt termiski modificētas koksnes aizsardzību pret koksnes krāsojošām sēnēm. Wocosen 45 TK sastāvā ir 34\% propikonazola un 16\% IPBC, un tā rekomendētās devas - 1\% aktīvo vielu. Testa rezultāti, kurā vērtējums veikts saskaṇā ar 2.1. tabulā dotajiem kritērijiem, ir atspogulıtoti 3. 9. tabulā. 
3.9. tabula. Termiski modificētas koksnes pārklājumā pievienota biocīda efektivitātes
novērtēšanas laboratorijas testa rezultāti

\begin{tabular}{lcc}
\hline \multicolumn{1}{c}{ Virsmas apstrāde } & \multicolumn{2}{c}{ Testa ilgums } \\
\cline { 2 - 3 } & $\mathbf{8}$ nedēlas & $\mathbf{1 0}$ nedēlas \\
\hline Bez pārklājuma & 1 & 1 \\
\hline Gruntsslānis bez biocīda & 4 & 4 \\
\hline Virsslānis $(2 \times)$ bez biocīda & 4 & 4 \\
\hline Gruntsslānis + virsslānis $(2 \times)$ bez biocīda & 0 & 1 \\
\hline Gruntslānis ar biocīdu & 0 & 0 \\
\hline Virsslānis $(2 \times)$ ar biocīdu & 0 & 0 \\
\hline Gruntslānis + virsslānis $(2 \times)$ ar biocīdu & 0 & 0 \\
\hline
\end{tabular}

Redzams, ka termiski modificēta koksne bez pārklājumu un ar šajā darbā lietotiem eksperimentāliem sastāviem nav pasargāta no krāsojošām koksnes sēnēm, bet ražotāju rekomendētās biocīda devas ir pietiekošas. Tādēḷ koksnes pasargāšanai visos pārklājuma eksperimentālajos sastāvos tika pievienots kompleksais biocīds. Pārbaudes āra testā parādīja, ka, salīdzinot ar rūpnieciskajiem pārklājumiem (R), paraugiem ar eksperimentālo sastāvu (EPS) apaugšana ar koksnes krāsojošām sēnēm ir līdzīgā līmenī (3.10. tabula).

3.10. tabula

Krāsojošās sēnes uz āra testa paraugiem, vidējais vērtējums ballēs

\begin{tabular}{|c|c|c|c|c|}
\hline \multirow{3}{*}{ Pārklājums } & \multicolumn{2}{|c|}{ Nemodificēta koksne } & \multicolumn{2}{|c|}{ Termiski modificēta koksne } \\
\hline & \multicolumn{4}{|c|}{ Ekspozīcijas laiks, mēneši } \\
\hline & Astoni & Desmit & Astoni & Desmit \\
\hline $\mathrm{R}-1$ & 1.7 & 4.0 & 0 & 1.3 \\
\hline $\mathrm{R}-2$ & 1.0 & 4.0 & 0 & 0.2 \\
\hline $\mathrm{R}-3$ & 2.0 & 4.0 & 0 & 0.5 \\
\hline $\mathrm{R}-4$ & 1.0 & 3.7 & 0 & 0.8 \\
\hline $\mathrm{R}-5$ & 2.3 & 4.0 & 0 & 0.3 \\
\hline $\mathrm{R}-6$ & 1.3 & 4.0 & 0 & 0.8 \\
\hline $\mathrm{R}$-vidējais & 1.4 & 4.0 & 0 & 0.7 \\
\hline EPS & 1.3 & 4.0 & 0 & 0.5 \\
\hline
\end{tabular}

Nemodificētai koksnei pirmā apaugšana tika konstatēta pēc astoņu mēnešu āra ekspozīcijas, un, saskaṇā ar 2.1. tabulā dotajiem kritērijiem, pēc desmit mēnešiem visiem paraugiem apaugums bija ḷoti smags. Termiski modificētai koksnei apaugšana sākās vēlāk un pēc desmit āra ekspozīcijas mēnešiem tā bija būtiski mazāka $(\mathrm{p}<0.05)$.

Visos eksperimentālajos pārklājumos kā nemainīgas funkcionālās piedevas tika lietotas arī žǔšanas veicinātājs - kobalta naftafenons un plēves veidošanās inhibitors EXKIN 2 (metiletilketoksīms). 
Pētījumos par termiski modificētai koksnei paredzētu plēvi neveidojošu alkīda pārklājumu uz šķ̣̄idinātāja bāzes sastāva optimizēšanu ir noskaidrots, ka:

- pārklājums, kurā kā saistviela izmantoti alkīda sveḳi un linsēklu el̦la attiecībā 2:1, nodrošina stabilu termiski modificētas koksnes virsmas aizsardzību pret ūdens iedarbību;

- pernica virsslāņa pārklājumā nodrošina labāku termiski modificētas koksnes krāsas saglabāšanos āra apstākḷos;

- termiski modificētas koksnes pasargāšanai pret krāsojošām sēnēm pārklājumos nepieciešams lietot biocīdus. Pietiekoša kompleksā biocīda (IPBC un propikonozols) koncentrācija ir 1\% aktīvo vielu;

- brīvo radikāḷu deaktivēšana, izmantojot koksnei paredzēto radikāļu deaktivātoru LIGNOSTAB, nav efektīvs pan̄ēmiens termiski modificētas koksnes virsmas pasargāšanai no UV starojuma izraisītām krāsu izmaiṇām;

- $\mathrm{TiO}_{2}$ un $\mathrm{ZnO}$ pievienošana pārklājumam būtiski paaugstina tā stiklošanās temperatūru, kas samazina pārklājuma elastību;

- caurspīdīgie dzelzs oksīda pigmenti nodrošina labāku termiski modificētas koksnes krāsas aizsardzību pret UV starojuma izraisītām izmain̄ām, salīdzinot ar kompleksā organiskā UV absorbera/brīvo radikāḷu deaktivātora piedevu. 


\section{4. Āra novecināšanas testu rezultāti}

\subsubsection{Bezpigmentu pārklājumi}

Sākotnēji tika veikti āra testi, lai novērtētu, vai novecošanās būtiski atšḳiras pie dažādām temperatūrām modificētai koksnei. Šajā pētījuma daḷā tika izmantoti tikai pie $160^{\circ} \mathrm{C}$ un $170^{\circ} \mathrm{C}$ modificēti paraugi, jo iepriekšējos pētījumos ir noskaidrots, ka modifikācija pie šīm temperatūrām nodrošina būtisku koksnes bioizturības paaugstināšanu (Rowell et al., 2013). N̦emot vērā līdzīgo, iepriekšèjās nodaḷas aprakstīto novecošanās procesu termiski modificētai apsei un baltalksnim, āra testi pamatā tika veikti ar apses koksnes paraugiem. Šāda paraugu atlase (ierobežošana) l̦āva pārbaudīt vairāk pārklājumu variantu, jo āra novecināšanas testos ḷoti atšķirīgo metrologisko apstākḷu dēḷ korekti ir salīdzināt tikai vienlaicīgi eksponētus paraugus, kuri ir bijuši pakḷauti vienādu vides faktoru iedarbībai. To labi ilustrē 3.60. attēlā parādītās termiski modificētas koksnes bez pārklājuma krāsas izmaiņas āra testā paraugiem no dažādiem āra testiem, kuri uzsākti dažādos laikos.

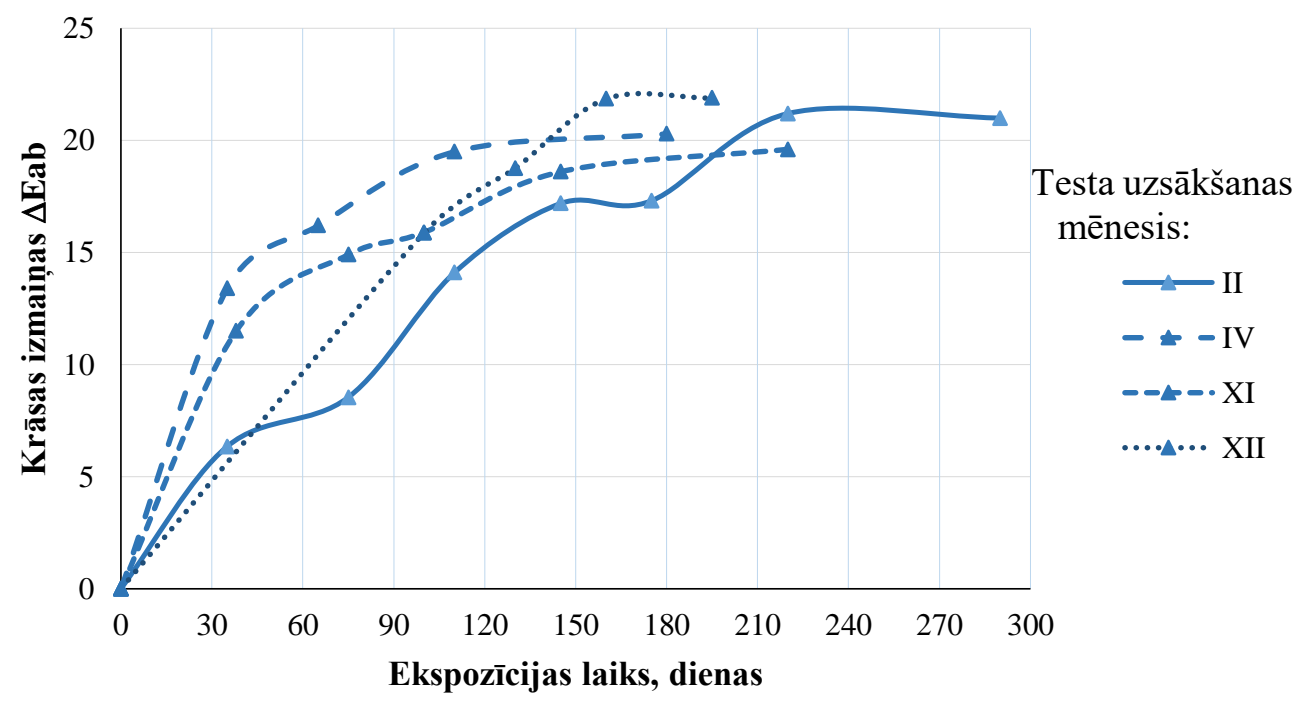

\subsection{0. att. Termiski modificētas $\left(\mathbf{1 7 0}^{\circ} \mathrm{C}\right)$ apses koksnes bez pārklājuma krāsas izmaiṇas dažādos laikos realizētos āra testos.}

Kā redzams, krāsu izmaiṇu ātrums dažādos testos būtiski atšķiras. Tā, piemēram, pēc trīs mēnešu (90 dienas) āra ekspozīcijas, krāsu izmaiņas testos svārstās no 11 līdz 18 $\Delta$ Eab vienībām. Arī maksimālās krāsas izmaiņas, pēc kuru sasniegšanas būtiskas izmaiņas vairs nenotiek un, kas visos testos ir līdzīgas (20 - $22 \Delta$ Eab vienības), paraugi sasniedz pēc dažādiem ekspozīcijas laikiem. Turklāt āra testi ir laikietilpīgi.

Lai mazinātu koksnes dabīgās heterogenitātes ietekmi uz rezultātiem, vienāds pārklājums tika lietots uz no viena dẹla izzāgeetiem, pie dažādām temperatūrām modificētiem paraugiem. Eksperiments tika veikts, izmantojot rūpnieciskos un eksperimentālos pārklājumus.

Koksnes uzṇemtais pārklājuma daudzums būtiski neatšḳ̄īās abām modifikācijas temperatūrām $(\mathrm{p}>0.05)$, bet bija vidēji par 10\% lielāks nekā nemodificētai koksnei. 
Pārrēḳinot uz pārklājuma sauso atlikumu, vidējie uzklātie daudzumi bija $18.4 \mathrm{~g} \mathrm{~m}^{-2}$ termiski modificētai koksnei un $16.8 \mathrm{~g} \mathrm{~m}^{-2}$ nemodificētai koksnei.

Āra testa laikā novecošanās tika vērtēta pēc krāsas izmain̄ām un plaisu veidošanās. Pirmās mikroplaisas, kuras tika vērtētas pēc 2.2. tabulā norādītiem kritērijiem, ātrāk parādījās termiski modificētiem paraugiem (3. 11. tab.). Nemodificētai koksnei plaisas parādījās vēlāk, toties testa beigās bija salīdzinoši intensīvākas.

3.11. tabula

\section{Plaisu novērtējums āra testa paraugiem, summārās balles}

\begin{tabular}{cccc}
\hline $\begin{array}{c}\text { Ekspozīcijas ilgums, } \\
\text { dienas }\end{array}$ & \multicolumn{3}{c}{ Koksnes veids } \\
\cline { 2 - 4 } & Nemodificēta & $\mathbf{T M}-\mathbf{1 6 0}^{\circ} \mathbf{C}$ & $\mathbf{T M}-\mathbf{1 7 0}^{\circ} \mathbf{C}$ \\
\hline 100 & $0.04(0.1)$ & $1.2(0.7)$ & $1.2(0.7)$ \\
\hline 130 & $3.8(1.1)$ & $4.0(0.9)$ & $3.1(0.8)$ \\
\hline 160 & $5.8(0.8)$ & $5.8(0.2)$ & $5.5(0.3)$ \\
\hline 195 & $7.3(0.2)$ & $6.0(0.0)$ & $6.0(0.1)$ \\
\hline
\end{tabular}

Iekavās uzrādītas standartnovirzes

Salīdzinot plaisu veidošanos pie $160^{\circ} \mathrm{C}$ un $170^{\circ} \mathrm{C}$ modificētas koksnes paraugiem, kas bija pārklāti ar vienādu pārklājumu, nav novērojamas būtiskas atškirīibas ( $p$ > 0.05) atkarībā no izmantotā koksnes substrāta. To labi ilustrē arī korelācijas diagramma un lineārās regresijas taisnes vienādojuma brīvā locekḷa nelielā vērtība un proporcionalitātes koeficienta vērtība, kas ir tuvu vienai vienībai (3.61. att.).

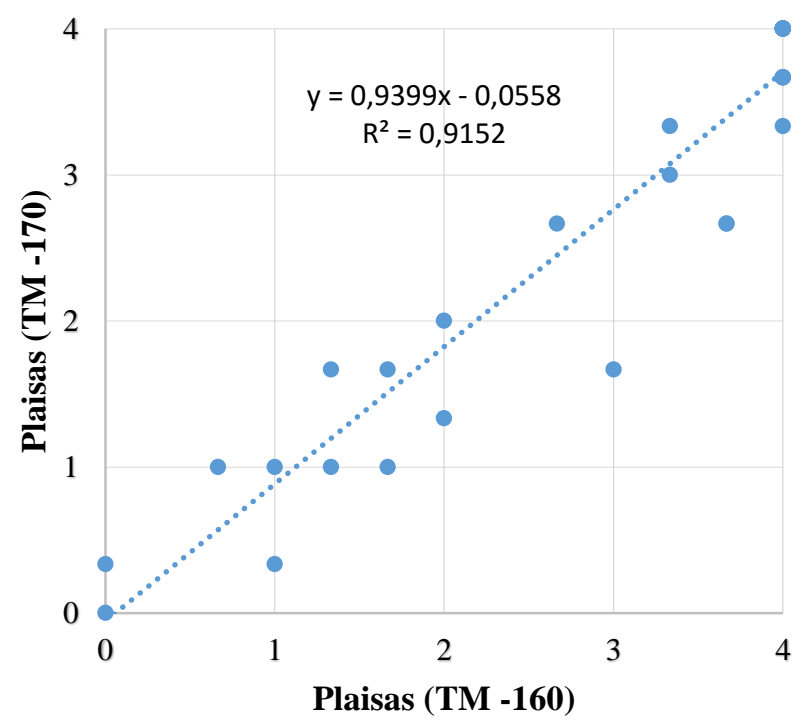

3.61. att. Plaisu salīdzinošs novērtējums pie $160^{\circ} \mathrm{C}(\mathrm{TM}-\mathbf{1 6 0})$ un $170^{\circ} \mathrm{C}(\mathrm{TM}-170)$ modificētas koksnes paraugiem ar vienādiem pārklājumiem āra novecināšanas laikā.

Atšķirīgās temperatūrās $\left(160^{\circ} \mathrm{C}\right.$ un $\left.170^{\circ} \mathrm{C}\right)$ modificētas koksnes paraugiem ar vienādiem pārklājumiem arī krāsas izmaiṇu tendences āra testā ir līdzīgas (3.62. att.). 


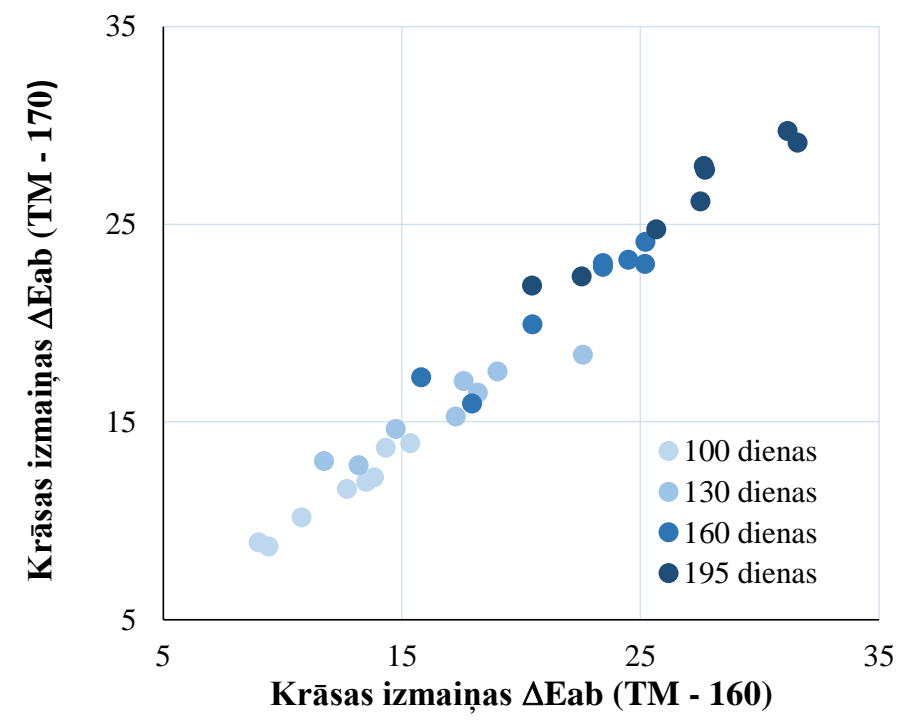

\subsection{2. att. Krāsu izmaiņas $\Delta$ Eab āra testa laikā pie $160^{\circ} \mathrm{C}(\mathrm{TM}-160)$ un $170^{\circ} \mathrm{C}$ (TM - 170) modificētas koksnes paraugiem ar vienādiem pārklājumiem.}

Šie āra testa rezultāti parāda, ka pie $160^{\circ} \mathrm{C}$ un $170^{\circ} \mathrm{C}$ termiski modificētas apses koksnes novecošanās raksturs zem vienāda veida pārklājumiem ir līdzīgs. Tādēl turpmākos pārklājumu efektivitātes izvērtēšanas testos kā termiski modificētas koksnes substrāts tika izmantota pie $170^{\circ} \mathrm{C}$ modificēta apses koksne.

\subsubsection{Dažādas koncentrācijas dzelzs oksīdu pigmenti}

No citiem pētījumiem ir zināms, ka bezpigmentu pārklājumi nenodrošina termiski modificētas koksnes aizsardzību āra apstākḷos (Jämsä et al., 2000). Kā tas tika noskaidrots eksperimentos par koksnes spektrālo jutību, termiski modificētai koksnei ievērojamas gan krāsas, gan ḳimiskās izmainas izraisa plašs saules starojuma spektra redzamās gaismas apgabals. Kā potenciāli piemērotākais aizsardzības variants bezplēves caurspīdīgiem pārklājumiem tika izvēlēti caurspīdīgo, krāsaino dzelzs oksīdu pigmentu preparāti. Optimālās pigmentu koncentrācijas tika noteiktas testā, kurā eksperimentālajam virsslāṇa bāzes pārklājumam (3.7. tab.) tika pievienoti sarkanā un dzeltenā (1:1) dzelzs oksīdu preparāti ar pigmentu masas attiecību 2\%, 4\%, 6\% pārklājuma škīdumā, jeb 10\%,20\% un 30\%, pārrēḳinot pret pārklājuma saistvielas sausnes daḷ. Salīdzinājumam tika sagatavoti arī termiski modificētas koksnes paraugi ar rūpniecisku atbilstošas klases (caurspīdīgs, plēvi neveidojošs, pigmentēts) koksnes pārklājumu. Kā pamatkritēriji, lai salīdzinātu pārklājuma spēju aizkavēt termiski modificētas koksnes novecošanos āra apstākḷos, tika izvēlētas krāsas izmainias un plaisu veidošanās.

Mikroplaisas ātrāk parādījās paraugiem ar pigmentētu pārklājumu ( 3.63. att.). 


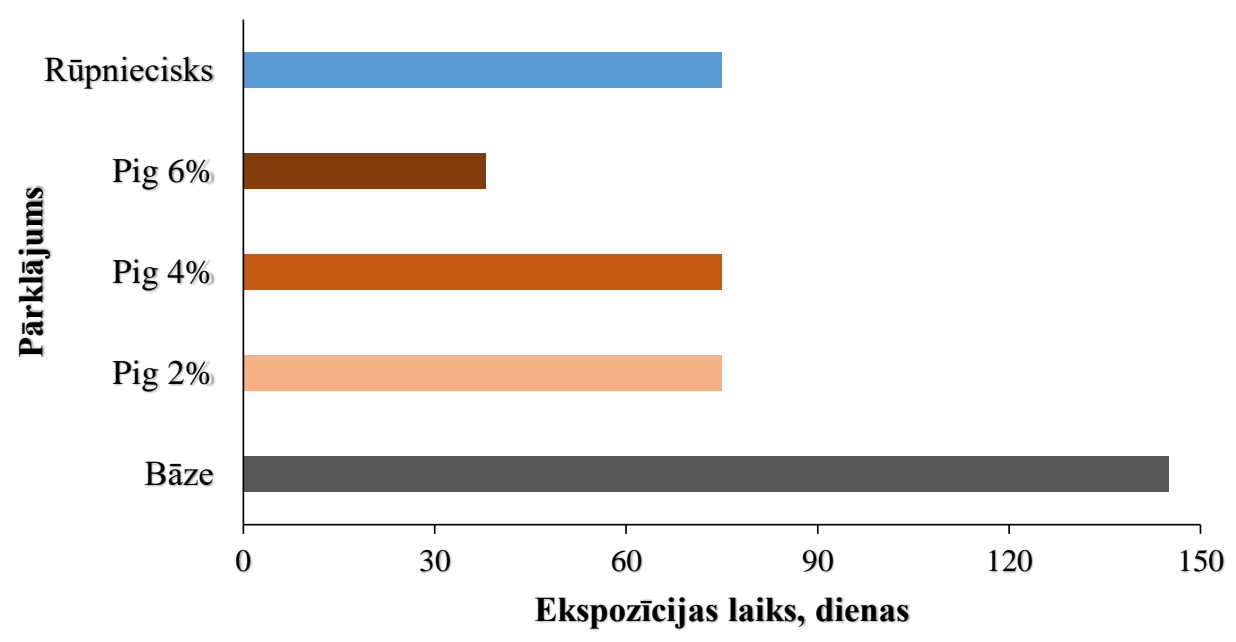

\subsection{3. att. Pirmo mikroplaisu fiksēšanas laiks āra testā termiski modificētai koksnei ar dažādiem pārklājumiem.}

Jau pirmajā kontroles reizē pēc 38 ekspozīcijas dienām pirmās ar mikroskopu pie $25 \times$ palielinājuma saskatāmās mikroplaisas tika konstatētas paraugiem, kuri bija pārklāti ar augstāko pigmentu koncentrāciju saturošo eksperimentālo pārklājumu. Pārējiem paraugiem ar pigmentētajiem pārklājumiem pirmās mikroplaisas tika konstatētas pēc 75 ekspozīcijas dienām. Savukārt paraugiem, kuru pārklājumā pigmentu piedevas nebija (Bāze), plaisas sāka veidoties ievērojami vēlāk. Tas norāda, ka pigmentu piedeva pārklājumam veicina ātrāku mikroplaisu veidošanos āra apstākḷos. Turklāt augstāka pigmentu koncentrācija paātrina plaisu veidošanos.

Toties pigmentētie pārklājumi būtiski palēnināja paraugu krāsas izmaiṇas (3.64. att.).

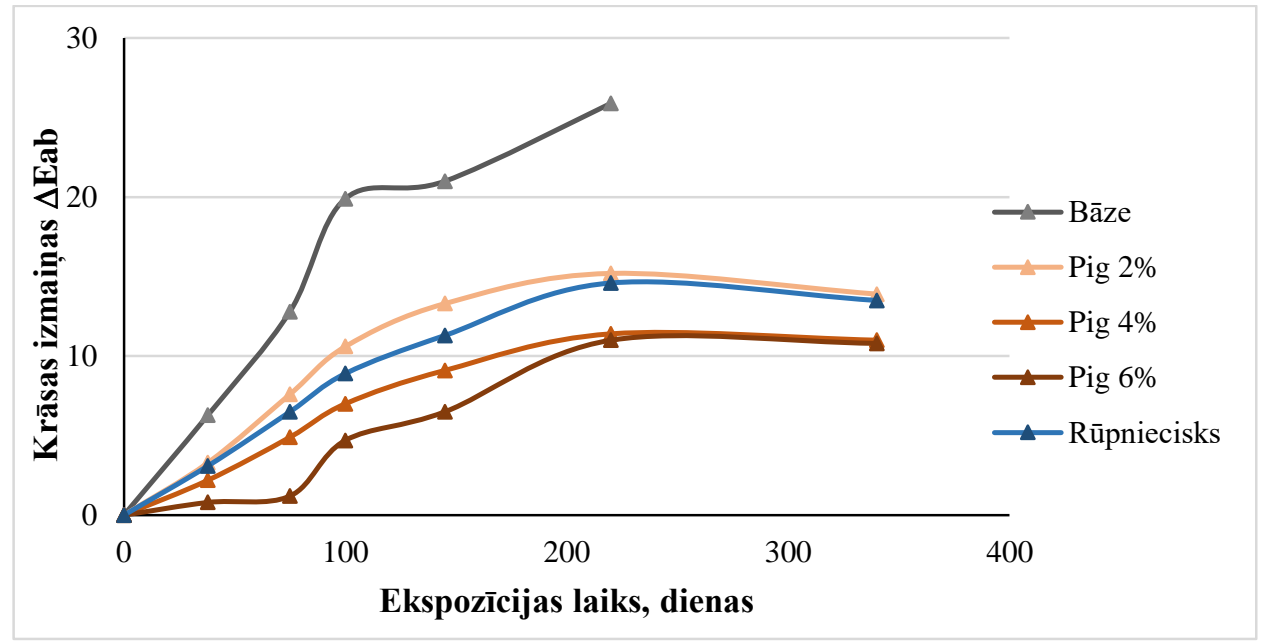

3.64. att. Termiski modificētas koksnes ar dažādiem pārklājumiem krāsas izmaiṇas āra testā.

Augstāka pigmentu koncentrācija (6\%) nodrošina labāku termiski modificētas koksnes krāsas saglabāšanos āra ekspozīcijas sākumposmā, bet ilgstošā periodā līdzīgs 
rezultāts ir, lietojot $4 \%$ un $6 \%$ pigmentu piedevu. Paraugiem ar eksperimentā izmantoto rūpniecisko pigmentēto pārklājumu gan krāsas izmaiṇu, gan mikroplaisu veidošanās rezultāti bija līdz̄igi paraugiem ar zemākās pigmentu koncentrācijas eksperimentālo sastāvu. Šī testa rezultāti parāda, ka optimāla pigmentu koncentrācija pārklājuma šḳīdumā varētu būt ap 4\%, jeb 20\%, pārrēķinot pret saistvielas sausni.

\subsubsection{Dažādas dzelzs oksīdu kompozīcijas}

Krāsainie dzelzs oksīdi, absorbējot daḷu redzamas gaismas, protams, izmaina pārklātā substrāta krāsu, bet termiski modificētas koksnes krāsu izmaina arī bezpigmentu pārklājums. Apskatot atstarošanas spektrus termiski modificētai koksnei ar un bez pārklājumiem, redzams, ka, salīdzinot ar bāzes pārklājumu, pigmentu pievienošana pārklājumam būtiski nepalielina atstarošanas atšķirības (3.65. att.).

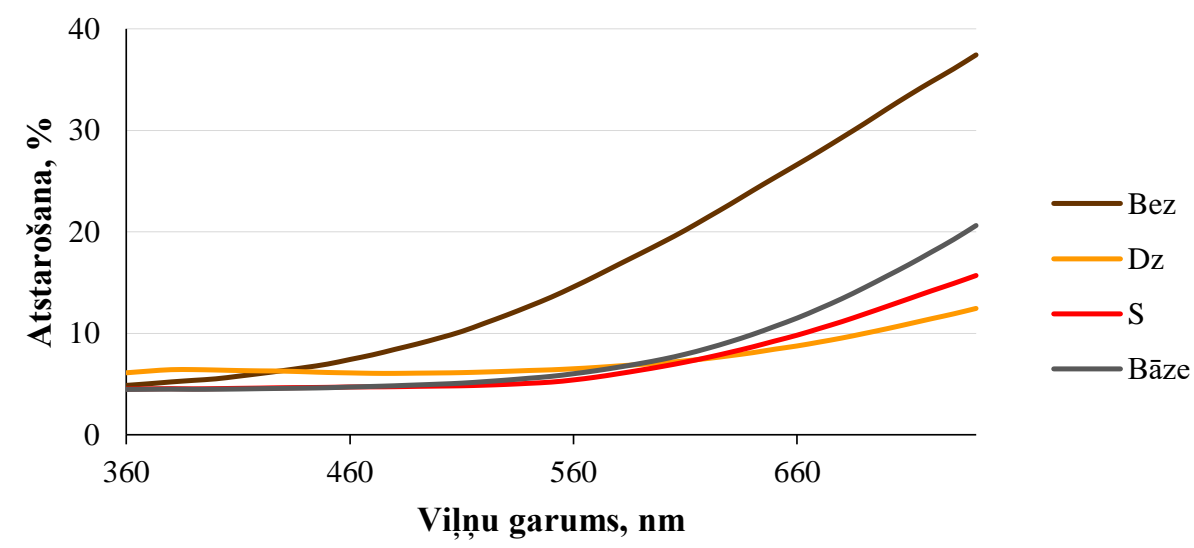

3.65. att. Atstarošanas spektri termiski modificētai koksne ar un bez pigmentiem. Apzīmējumi: DZ - dzeltenais dzelzs oksīda pigments; S - sarkanais dzelzs oksīda pigments.

Tā kā termiski modificētas koksnes ar pārklājumu krāsas atšķirības, lietojot sarkano vai dzelteno dzelzs oksīdu piedevu, ir nelielas, viena vai otra dzelzs oksīda pigmenta lietošana neveido produktus ar būtiski atškirīgām dekoratīvajām īpašīiām. Tādēl, izvēloties piemērotāko pigmentu piedevu, galvenais kritērijs var būt tā funkcionālā spēja nodrošināt labāko aizsardzību pret novecošanos.

Testā tika salīdzināti pārklājumi, kuri satur vienādas koncentrācijas (4\%) dzeltenā un sarkanā dzelzs oksīda maisījumu (1:1), kā arī atsevišķi tikai dzelteno vai sarkano dzelzs oksīdu (3.66. att.). 


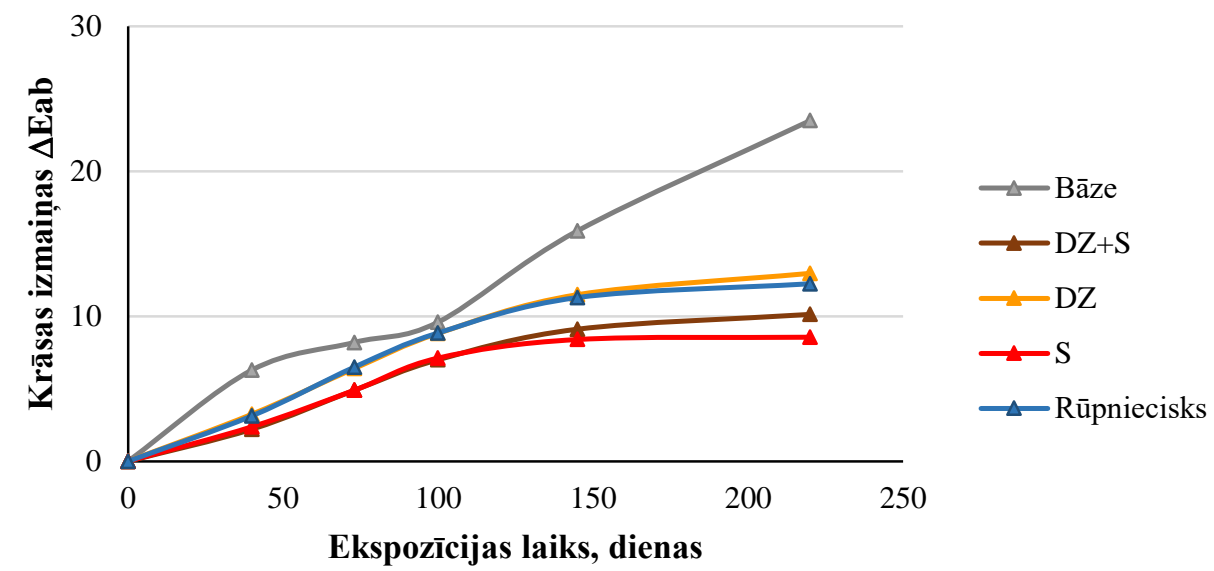

3.66. att. Krāsas izmaiṇas termiski modificētai koksnei ar dažāda sastāva pigmentētiem pārklājumiem āra testā.

Apzīmējumi: DZ - dzeltenais dzelzs oksīda pigments; $\mathrm{S}$ - sarkanais dzelzs oksīda pigments.

Testa sākuma posmā nav būtisku krāsu izmaiṇu atškirīību paraugiem ar dažādus pigmentus saturošiem pārklājumiem, bet pēc pus gada, izmantojot pārklājums ar sarkano dzelzs oksīdu, parauga krāsas izmaiṇas ir par 50\% mazākas, salīdzinot ar dzelteno dzelzs oksīdu saturošu pārklājumu. Šādam rezultātam skaidrojums varētu būt eksperimentā par koksnes novecošanos dažādu saules starojuma apgabalu ietekmē noskaidrotā termiski modificētas koksnes spektrālā jutība pret starojumu ar viḷnu garumu virs $600 \mathrm{~nm}$. Sarkano dzelzs oksīdu saturoša pārklājumu plēves caurlaišanas spektrs ir būtiski nobīīits uz garāko vilı̣nu apgabalu (3.67. att.). Līdz ar to tas spēj labāk aizsargā termiski modificētu koksni pret saules iedarbību.

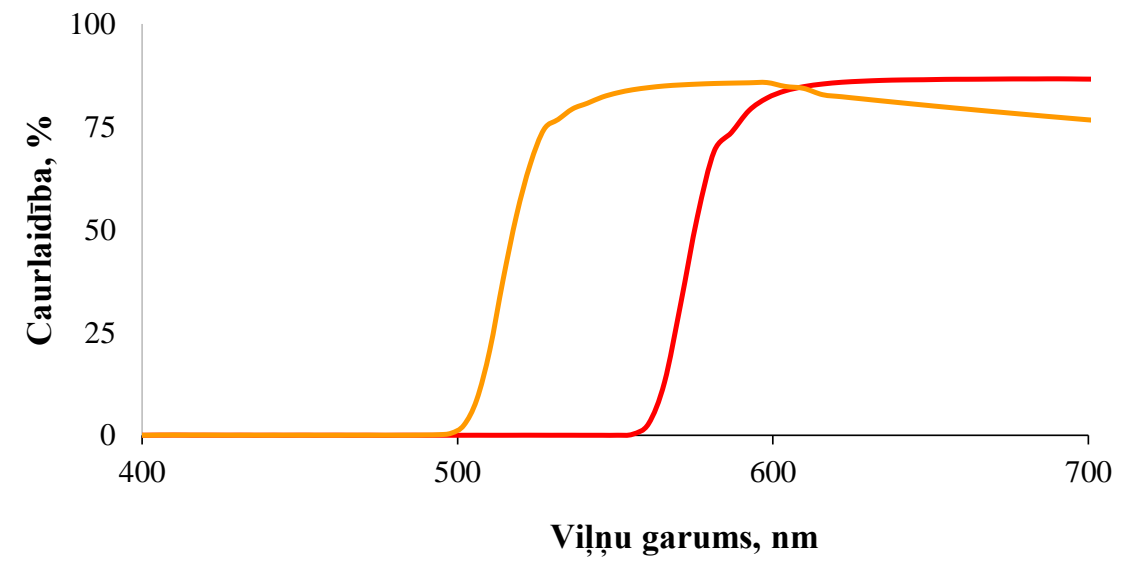

\subsection{7. att. Sarkano un dzelteno dzelzs oksīda pigmentu saturošu pārklājumu plēvju gaismas caurlaidības spektri redzamās gaismas apgabalā.}

Lai arī pārklājuma slānis uz koksnes ir daudz plānāks nekā pārklājumu gaismas caurlaidības testam pagatavotās plēves un tādēl pārklājuma kopējā gaismas caurlaidība ir ievērojami lielāka, tomēr sarkano dzelzs oksīdu saturošā pārklājuma relatīvi lielāka 
aizturētās redzamās gaismas starojuma daḷa varētu mazināt saules starojuma izraisītās krāsu izmaiṇas termiski modificētā koksnē.

\subsubsection{Pigmentēti pārklājumi ar UV absorbera piedevu}

Krāsainie dzelzs oksīdi absorbē starojumu ne tikai redzamajā, bet arī spektra UV daļā, tādējādi vienlaicīgi darbojoties arī kā UV absorberi. Mākslīgās novecināšanas kameras UV testā jau tika parādīts, ka dzelzs oksīda pigmenti ilgstošā laika posmā varētu būt efektīvāki termiskās koksnes aizsardzībā pret UV starojumu, salīdzinot ar organiskajiem UV absorberiem. Tomēr UV absorberu loma koksnes pārklājumos nav tikai koksnes, bet arī paša pārklājuma aizsardzība pret fotodegradāciju. Neorganiskie UV absorberi, tai skaitā arī dzelzs oksīdi, pārklājumā atrodas sīku, dispersu dalinu, veidā. Organiskie UV absorberi pārklājumā tiek ievadīti šķīduma veidā un ir molekulu formā, kas nodrošina to daudz vienmērīgāku sadalījumu pārklājuma virsējā slānī. Tas varētu nodrošināt labāku paša pārklājuma aizsardzību, aizkavējot tā virsmas erozijas procesus un pigmentu izskalošanos.

Tādēḷ āra testā tika pārbaudīts, vai, pigmentētā pārklājumā papildus pievienojot organisko absorberi, var nodrošināt labāku termiski modificētas koksnes aizsardzību pret novecošanos āra apstākḷos. Pirmajās kontroles reizēs, kas tika veiktas pēc 40 un 70 dienu ilgas paraugu ekspozīcijas, paraugiem ar pigmentēto pārklājumu, kurā papildus bija pievienots organiskais UV absorberis, krāsu izmaiṇas bija būtiski mazākas $(\mathrm{p}<0.05)$ (3.68. att.).

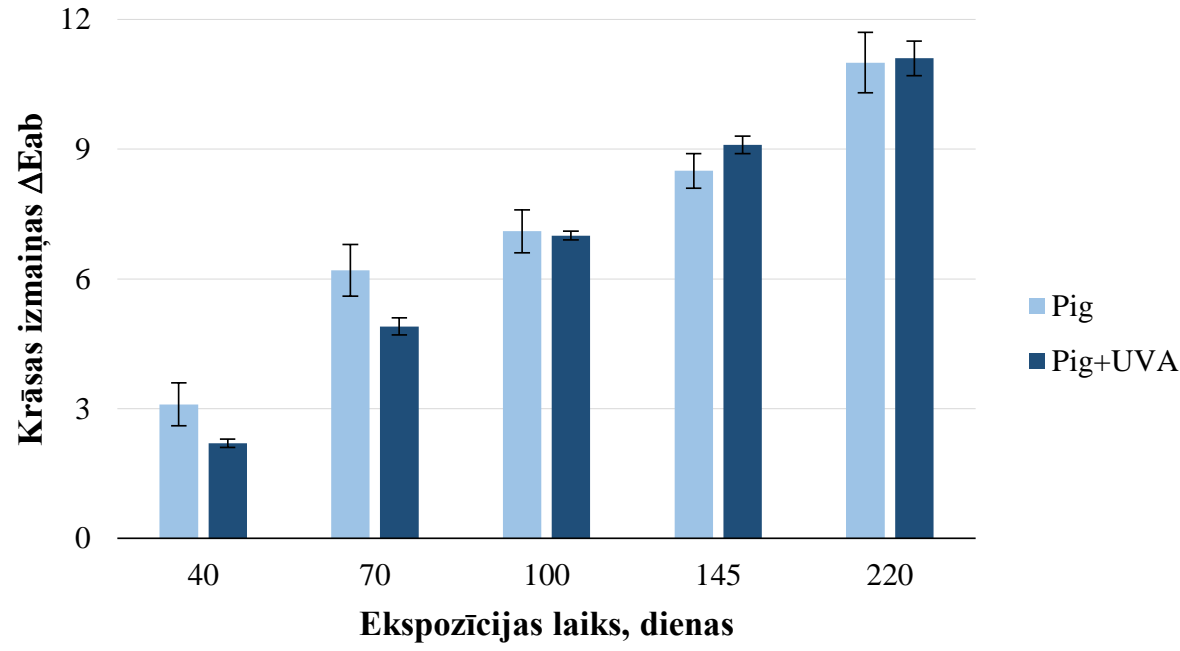

\subsection{8. att. Termiski modificētas koksnes krāsas izmaiṇas $\Delta$ Eab ( \pm standartnovirzes) āra testā.}

Tomēr organiskā UV absorbera piedeva nenodrošina ilgstoši labāku termiski modificētas koksnes aizsardzību pret krāsas izmaiṇām, un kontrolē pēc 100 dienu ekspozīcijas vairs nebija būtisku atšķirību starp abu grupu paraugiem ( $\mathrm{p}>0.05)$.

Turklāt UV organiskā absorbera piedeva pārklājumā arī nenodrošina labāku termiski modificētas koksnes aizsardzību pret plaisu veidošanos. Gan paraugiem ar UV 
absorberi saturošu pārklājumu, gan tikai pigmentētu pārklājumu pirmās mikroplaisas tika konstatētas vienā laikā - kontroles reizē pēc 70 dienu ekspozīcijas. Šie rezultāti rāda, ka organiskā UV absorbera pievienošana pigmentētiem pārklājumiem nodrošina tikai īslaicīgu pārklājuma aizsardzības efektivitātes uzlabojumu, tādējādi to lietošana šādos pārklājumos nav ne ekonomiski, ne ekologiski pamatota. Arī pētījumā par nemodificētas koksnes aizsardzību ar pigmentētu pārklājumu ir novērots, ka pie pietiekoši augstas pigmentu koncentrācijas papildus UV absorbera lietošana nav nepieciešama. (Schauwecker et al., 2014).

Pētījumu daḷā par termiski modificētai koksnei paredzētu plēvi neveidojošu alkīda pārklājumu uz šḳīdinātāja bāzes sastāvu ir noskaidrots, ka:

- augstāka pigmentu koncentrācija (6\%) nodrošina labāku termiski modificētas koksnes krāsas saglabāšanos āra ekspozīcijas sākumposmā, bet ilgstošā periodā līdzīgs rezultāts ir, lietojot $4 \%$ un $6 \%$ pigmentu piedevu;

- pigmentu piedeva pārklājumam veicina ātrāku mikroplaisu veidošanos āra apstākḷos, augstāka pigmentu koncentrācija paātrina plaisu veidošanos;

- mazākas termiski modificētas koksnes krāsas izmaiṇas nodrošina sarkanā dzelzs oksīda pigmenta piedeva pārklājumam, kas saistīts ar tam raksturīgo garāko redzamās gaismas viḷ,nu absorbciju;

- caurspīdīgo dzeltenā un sarkanā dzelzs oksīdu pigmentu pievienošana bāzes pārklājumam neizsauc būtiskas izmaiņas termiski modificētas koksnes atstarošanas spektrā;

- organiskā UV absorbera pievienošana pārklājumam, kas kā pigmentus satur caurspīdīgos dzelzs oksīdus, termiski modificētas koksnes krāsas saglabāšanos uzlabo tikai āra ekspozīcijas sākuma periodā, bet ne ilglaicīgi. 


\section{SECINĀJUMI UN PRIEKŠLIKUMI}

\section{SECINĀJUMI}

1. Apsei un baltalksnim termiskās modifikācijas procesā veidojas līdzīga, zem būtiski tumšāka virsslāṇa gaišāka, homogēna un, ja koksne nav pakḷauta saules starojuma iedarbībai, stabila krāsa. Termiski modificētas koksnes raksturīgo krāsu nosaka ar koksnes pamatkomponentiem saistītas hromoforās grupas. Paaugstinot modifikācijas temperatūru, pieaug hromoforo grupu, kam raksturīga absorbcija redzamās gaismas garāko viḷnu apgabalā, īpatsvars.

2. Atškirīīā no nemodificētas koksnes, UV viḷnu diapazons nav dominējošais saules iedarbībai pakḷautas termiski modificētas lapkoku koksnes krāsas izmaiņas izraisošais solārā starojuma apgabals. Būtiskas gan krāsas, gan ķīmiskās izmaiņas uz termiski modificētas koksnes virsmas izraisa saules starojuma redzamā gaisma, tai skaitā, ar viḷnu garumu virs 500 nm, ko ir svarīgi ņemt vērā, veidojot pārklājumus modificētas koksnes aizsardzībai.

3. Termiski modificētai un nemodificētai lapkoku koksnei paredzētu plēvi neveidojošu alkīda sveḳu pārklājumu uz šḳīinātāja bāzes optimālie sastāvi atšķiras. Trešdaļu no sveķiem aizstājot ar linsēklu eḷıu vai pernicu, iegūst pārklājumu, kas, lietots uz termiski modificētas lapkoku koksnes, veido pret ūdens caurlaidību stabilu $<$ koksne-pārklājums $>$ sistēmu.

4. Pārklājumos, kas paredzēti termiski modificētas lapkoku koksnes aizsardzībai, vienlaicīgi saglabājot tās dabīgo izskatu, saules starojuma iedarbības ierobežošanai piemērota ir caurspīdīgā, sarkanā dzelzs oksīda piedeva. Labākais rezultāts, izmantojot eksperimentālo pārklājuma sastāvu, tika sasniegts, tam pievienojot 4\% dzelzs oksīda piedevu bez papildus UV absorbera lietošanas.

\section{PRIEKŠLIKUMI}

- Kā vienu no iespējām paplašināt apses un baltalkšña izmantošanas jomas, būtu kompleksi jāizvērtē šo sugu koksnes termiskā modifikācija, kas ḷauj iegūt materiālu ar labām dekoratīvām īpašībām un augstāku pievienoto vērtību.

- Risinot termiski modificētas koksnes aizsardzības un dekorativitātes saglabāšanas jautājumus, rekomendējams ņemt vērā šai koksnei raksturīgo spektrālo jutību un izmantot pigmentētus pārklājumus, kas spēj absorbēt saules starojuma spektra īsākos viḷnus vismaz līdz $600 \mathrm{~nm}$.

- Vēlams apsvērt speciāli termiski modificētai koksnei paredzētu pārklājumu ražošanu, kuros kā saistviela apvienoti alkīda sveḳi un linsēklu ellıa (gruntsslānim) vai linsēklu elı̣as pernica (virsslānim), kas, vienlaicīgi nodrošinot labu aizsardzību, padarītu pārklājumus ekonomiskākus un videi draudzīgākus.

- Pētniecības jomā nepieciešams: turpināt pētījumus par termiski modificētas skujkoku koksnes dekoratîvajām īpašībām un to saglabāšanas iespējām; izstrādāt optimālus, plēvi veidojošus, caurspīdīgus pārklājumus termiski modificētas koksnes dekorativitātes saglabāšanai; noskaidrot ekologiiskos un ekonomiskos aspektus pārklājumu uz ūdens bāzes izmantošanai termiski modificētas koksnes aizsardzībai. 


\section{PATEICĪBAS}

Liels paldies promocijas darba zinātniskajiem vadītājiem Prof., Dr. habil. sc. ing., Dr. h. silv. Hennam Tuhermam un Dr. chem. Bruno Andersonam par man veltīto laiku un atbalstu darba izstrādāšanā.

Īpašs paldies Ingeborgai Andersonei par palīdzību un vērtīgajiem padomiem rezultātu izvērtēšanā un manuskripta kvalitātes uzlabošanā.

Vēlos arī pateikties visiem maniem esošajiem un bijušajiem kolēǵiem Latvijas Valsts Koksne ķīmijas institūtā, kuri palīdzēja darba tapšanā: Andim Antonam, Anetei Meijai-Feldmanei, Annai Janbergai, Arnim Kokorevičam, Edgaram Kukam, Elīnai Kapačai, Errj Sansonetti, Ilzei Irbei, Jurim Grīniņam, L,ubovai Beḷkovai, N̦inai Kurnosovai, Anrijam Verovkinam, Dzintrai Vilsonei.

Sirsnīgs paldies manai gimenei un draugiem par ticību, uzmundrinājumu un lielo atbalstu. 


\section{INFORMĀCIJAS AVOTU SARAKSTS}

1. Abel G. (1999) Pigments for paint. In: Paints and Coatings. Theory and Practice. Second edition. Lambourne R., Strivens T.A. (ed.), Cambridge, Woodhead Publishung Ltd., 91-165.

2. Agarwal U.P. (1999) On the importance of hydroquinone/p-quinone redox system in the photoyellowing of mechanical pulps. In: Proceedings of the 10th International Symposium on Wood and Pulping Chemistry, TAPPI Press, 1, 694697.

3. Agresti G., Bonifazi G., Calienno L., Capobianco G., Monaco A.L., Pelosi C., Picchio R., Serranti S. (2013) Surface investigation of photo-degraded wood by colour monitoring, infrared spectroscopy, and hyperspectral imaging. Journal of Spectroscopy, article ID 380536, 13.

4. Ahajji A., Diouf P.N., Aloui F., Elbakali I., Perrin D., Merlin A., George B. (2009) Influence of heat treatment on antioxidant properties and colour stability of beech and spruce wood and their extractives. Wood Science and Technology, 43, 69-83.

5. Ahmed S.A., Hansson L., Morén T. (2013a) Distribution of preservatives in thermally modified Scots pine and Norway spruce sapwood. Wood Science and Technology, 47(3), 499-513.

6. Ahmed S.A., Sehlstedt-Persson M., Morén T. (2013b) Mould susceptibility of Scots pine (Pinus sylvestris L.) sapwood: Impact of drying, thermal modification and copper-based preservative. International Biodeterioration and Biodegradation, 85, 284-288.

7. Ahola P., Derbyshire H., Hora G., de Neijer M. (1999) Water protection of wood window joinery paint with low organic solvent content paints with known composition. Holz als Roh-und Werkstoff, 57, 45-50.

8. Akgül M., Korkut S. (2012) The effect of heat treatment on some chemical properties and colour in Scots pine and Uludag fir wood. International Journal of Physical Sciences, 7(21), 2854-2859.

9. Allegretti O., Brunetti M., Cuccui I., Ferrari S., Nocetti M., Terziev N. (2012) Thermo-vacuum modification of spruce (Picea abies Karst.) and fir (Abies alba Mill.) wood. Bioresources, 7(3), 3659-3669.

10. Aloui F., Ahajji A., Irmouli Y., George B., Charrier A. (2006) Photostabilisation of the "wood-clearcoatings' systems with UV absorbers: correlation with their effect on the glass transition temperature. Journals of Physics: Conference Series, 40, 118-123.

11. Aloui F., Ahajji A., Irmouli Y., George B., Charrier B., Merlin A. (2007) Inorganic UV absorbers for the photostabilisation of wood-clearcoating systems: Comparison with organic UV absorbers. Applied Surface Science, 253, 37373745.

12. Altgen M., Militz H. (2015) Effect of temperature and steam pressure during the thermal modification process. In: Proceedings of the Eighth European Conference on Wood Modification. Helsinki, Finland, 2015, 226-233.

13. Anderson E.I., Pawlak Z., Owen N.L., Feist W.C. (1991) Infrared studies of wood weathering. Part II: Hardwoods. Applied Spectroscopy, 45, 648-652.

14. Andersons B., Andersone I., Biziks V., Irbe I., Chirkova J., Sansonetti E., Grinins J., Militz H. (2010) Hydrothermal modification for upgrading the durability properties of soft deciduous wood. The International Research Group Wood Preservation, Document IRG/WP 10-40494, 1-12. 
15. Andrady A.L., Hamid H.S., Torikai A. (2003) Effects of climate change and UVB on materials. Photochemistry and Photobiology Science, 2, 68-72.

16. Arnold M. (2012) Effect of heat treatment on the variability of wood material properties. In: Proceedings of the Sixth European Conference on Wood Modification, 2012, Ljublana, Slovenia, 557-564.

17. Arnold M. (2010a) Effect of moisture on bending properties of thermally modified beech and spruce. Journal of Materials Science, 45(3), 669-680.

18. Arnold M. (2010b) Planing and sanding of wood surfaces - effects on surface properties and coating performance. Congress Papers of the PRA's 7th International Woodcoatings Congress, The Netherlands, Paper No 32, 1-12.

19. Arnold M. (2007) Transverse anisotropy in thermally modified beech and spruce. In: Proceedings of $3^{\text {rd }}$ European Conference on Wood Modification, 2007, Cardiff, UK, 161-164.

20. Arnold M., Sell J., Feist W.C. (1991) Wood weathering in fluorescent ultraviolet and xenon arc chambers. Forest Products Journal, 41(2), 40-44.

21. Ates S., Akyildiz M.H., Ozdemir H. (2009) Effects of heat treatment on Calabrian pine (Pinus brutia Ten.) wood. Bioresources, 4(3), 1032-1043.

22. Athawale V.D., Nimbalkar R.V. (2011) Waterborne coatings based on renewable oil resources: an overview. Journal of American Oil and Chemical Society, 88, 159-185.

23. Auclair N., Riedl B., Blanchard V., Blanchet P. (2011) Improvement of photoprotection of wood coatings by using inorganic nanoparticles as ultraviolet absorbers. Forest Products Journal, 61(1), 20-27.

24. Awoyemi L., Jones I.P. (2011) Anatomical explanations for the changes in properties of western red ceder (Thuja plicata) wood during heat treatment. Wood Science and Technology, 45(2), 261-267.

25. Bächle H., Niemz P., Schneider T. (2007) Physical-mechanical properties of hard- and softwood heat treated in an autoclave. In: Proceedings of the Third European Conference on Wood Modification, Cardif, UK, 393-400.

26. Bächle H., Zimmer B., (2012) Wegener G. Classification of thermally modified wood by FT-NIR spectroscopy and SIMCA. Wood Science and Technology, 46, 1181-1192.

27. Bakali I., Yagi S., Hamzah M., George B., Merlin A., Deglise X. (2014) Influence of thermal treatment and impregnation on the durability of wood colour. Journal of Forest Products and Industries, 3(1), 42-49.

28. Bardage S.L. (1998) Susceptibility of painted wood to Aureobasidium pullulans: fungal stain and growth pattern. Holz als Roh-und Werkstoff, 56, 359-364.

29. Baur S.I., Easteal A.J. (2012) Improved photoprotection of wood by chemical modification with silanes: NMR and ESR studies. Polymers for Advanced Technologies, 24(1), 97-103.

30. Bekhta P., Niemz P. (2003) Effect of High Temperature on the Change in Color, Dimensional Stability and Mechanical Properties of Spruce Wood. Holzforschung, 57(5), 539-546.

31. Bentley J. (1999) Organic film formers. In: Paints and Coatings. Theory and Practice. Second edition. Lambourne R., Strivens T.A. (ed.), Woodhead Publishung Ltd., Cambridge, England, 19-90.

32. Beyer M., Koch H., Fischer K. (2006) Role of hemicelluloses in the formation of chromophores during heat treatment of bleached chemical pulps. Molecular Symposia, 232(1), 98-106. 
33. Bhuiyan M.T.R., Hirai N., Sobue N. (2000) Changes of crystallinity in wood cellulose by heat treatment under dried and moist conditions. Journal of Wood Science, 46, 431-436.

34. Bieleman J., Bolle T., Braig A., Glasel J.K., Spang R., Köhler M., Valet A. (2000) Additives for special functions. In: Additives for Coatings, Bieleman J. (ed.), Wiley-VCH, Weinheim, Federal Republic of Germany, 257-352.

35. Biziks V., Andersons B., Sansonetti E., Andersone I., Militz H., Grinins J. (2015) One stage thermo-hydro treatment (THT) of hardwoods: an analysis of form stability after five soaking-drying cycles. Holzforschung, 69(5), 563-571.

36. Blanchard V., Blanchet P. (2011) Color stability for wood products during use: effects of inorganic nanoparticles. Bioresources, 6(2), 1219-1229.

37. Boonstra M.J., Rijsdijk J.F., Sander C., Kegel E., Tjeerdsma B., Militz H., van Acker J., Stevens M. (2006a) Microstructural and physical aspects of heat treated wood. Part 1. Softwoods. Maderas. Ciencia y Technologia, 8(3), 193-208.

38. Boonstra M.J., Rijsdijk J.F., Sander C., Kegel E., Tjeerdsma B., Militz H., van Acker J., Stevens M. (2006b) Microstructural and physical aspects of heat treated wood. Part 2. Hardwoods. Maderas. Ciencia y Technologia, 8(3), 209-217.

39. Boonstra M.J., Tjeerdsma B. (2006) Chemical analysis of heat treated softwoods. Holz als Roh- und Werkstoff, 64(3), 204-211.

40. Boonstra M.J., van Acker J., Tjeerdsma B. F., Kegel E.V. (2007) Strength properties of thermally modified softwoods and its relation to polymeric structural wood constituents. Annals of Forest Science, 64(7), 679-690.

41. Borrega M., Kärenlampi P.P. (2008a) Effect of relative humidity on thermal degradation of Norway spruce (Picea abies) wood. Journal of Wood Science, 54, 323-328.

42. Borrega M., Kärenlampi P.P. (2008b) Mechanical behaviour of heat-treated spruce (Picea abies) wood at constant moisture content and ambient humidity, Holz als Roh- und Werkstoff, 66, 63-69.

43. Borrega M., Kärenlampi P.P. (2010) Hygroscopicity of heat-treated Norway spruce (Picea abies) wood. European Journal of Wood Products, 68 (2), 233235.

44. Box Plot: Display of Distribution. Pieejams: http://www.physics.csbsju.edu/stats/box2.html [skatīts 2015.gada 10.oktobrī]

45. Brennan P., Fedor C. (2007) Sunlight, ultraviolet, and accelerated weathering. In: Coatings Technology: Fundamentals, Testing, and Processing Techniques, Tracton A. (ed.), CRC Press, (12), 1-10.

46. Brischke C., Welzbacher C.R., Brandt K., Rapp A.O. (2007) Quality control of thermally modified timber: Interrelationship between heat treatment intensities and CIE L*a*b* color data on homogenized wood samples. Holzforschung, 61, $19-22$.

47. Brito J.O., Silva F.G., Leão M.M., Almeida G. (2008) Chemical composition changes in eucalyptus pinus woods submitted to heat treatment. Bioresource Technology, 99, 8545-8548.

48. Buchelt B., Wagenführ A. (2012) Evaluation of colour differences on wood surfaces. European Journal of Wood and Wood Products, 70, 389-391.

49. Budakci M. (2006) Effect of outdoor exposure and bleaching on surface color and chemical structure of scots pine. Progress in Organic Coatings, 56, 46-52.

50. Bulian F., Graystor J.A. (2009) Industrial Wood Coatings. Elsevier, Oxford, UK, 320 . 
51. Burgert I., Dunlop J.W.C. (2011) Micromechanics of cell walls. In: Mechanical Integration of Plant Cells and Plants. P.Wojtaszek (ed.), Springer-Verlag, Berlin, 27-52.

52. Burmester V.A. (1973) Einfluss einer Wärme--Druck-Behandlung haldtrockenen Holzes auf seine Formbeständigkeit. Holz als Roh-und Werkstoff, 31, 237-243.

53. De la Caba K., Guerrero P., del Rio M., Mondragon I. (2007) Weathering behaviour of wood-faced construction materials. Construction and Building Materials, 21, 1288-1294.

54. De Cademartori P.H.G., Schneid E., Gatto D.A., Stangerlin D.M., Beltrame R. (2013) Thermal modification of Eucalyptus grandis wood: variation of colorimetric parameters. Maderas, Ciencia y Tecnologia, 15(1), 1-8.

55. Calonego F.W., Severo E.T.D., Ballarin A.W. (2012) Physical and mechanical properties of thermally modified wood from E. Grandis. European Journal of Wood Products, 70(4), 453-460.

56. Chang H.T., Chang S.T. (2001) Correlation between softwood discoloration induced by accelerated lightfastness testing and by indoor exposure. Polymer Degradation and Stability, 72(2), 361-365.

57. Chang H.T., Su Y.C., Chang S.T. (2006) Studies on photostability of butyrylated, milled wood lignin using spectroscopic analyses. Polymer Degradation and Stability, 91, 816-822.

58. Chang T.C., Chang H.T., Wu C.L., Chang S.T. (2010) Influences of extractives on the photodegradation of wood. Polymer Degradation and Stability, 95, 516521.

59. Chaouch M., Dumarcay S., Pétrissans A., Pétrissans M., Gerardin P. (2013) Effect of heat treatment intensity on some conferred properties of different European softwood and hardwood species. Wood Science and Technology, 47, 663-673.

60. Chaouch M., Pétrissans M., Pétrissans A., Gerardin P. (2010) Use of wood elemental composition to predict heat treatment intensity and decay resistance of different softwood and hardwood species. Polymer Degradation and Stability, 95, 2255-2259.

61. Chen Y., Fan Y., Gao J., Stark N.M. (2012a) The effect of heat treatment on the chemical and color change of black locust (Robinia pseudoacacia) wood flour. Bioresources, 7(1), 1157-1170.

62. Chen Y., Gao J., Fan Y., Tshabalala M.A., Stark N.M. (2012b) Heat-induced chemical and color changes of extractive-free black locust (Robinia pseudoacacia) wood. Bioresources, 7(2), 2236-2248.

63. Chirkova J., Andersons B., Andersone I. (2007) Study of the structure of woodrelated biopolymers by sorption methods. Bioresources, 4(3), 1044-1057.

64. CIE 85 Solar Spectral Irradiance (1st Edition) (E), 1989.

65. CIELAB 1976 Color Space. Pieejams: http://www.rpdms.com/cielch/index.html [skatīts 2016. gada 3.janvārī].

66. Cirule D., Kuka E. (2015) Effect of thermal modification on wood colour. In: Proceedings of the Annual 21 st International Scientific Conference Research for Rural Development 2015, Jelgava, Latvia, Vol.2, 87-92.

67. Clausen C. A., Yang V. W. (2005) Azole-based antimycotic agents inhibit mold on unseasoned pine. International Biodeterioration and Biodegradation, 55, 99102. 
68. Clausen C.A., Green F., Kartal S.N. (2010) Weatherability and leach resistance of wood impregnated with nano-zinc oxide. Nanoscale Research Letters, 5, 1464-1467.

69. Coating types and characteristics. (1995) In: Painting: New Construction and Maintenance. Engineer Manual, US Army Corps of Engineers, Washington, (4) $1-24$.

70. Colom X., Carrillo F., Nogues F., Garriga P. (2003) Structural analysis of photodegraded wood by means of FTIR spectroscopy. Polymer Degradation and Stability, 80(3), 543-549.

71. Creemers J., de Meijer M., Zimmermann T., Sell J. (2002) Influence of climatic factors on the weathering of coated wood. Holz als Roh-und Werkstoff, 60, 411420.

72. Croll S., Hinderliter B. (2008) A framework for predicting the service lifetime of composite polymeric coatings. Journal of Material Science, 43, 6630-6641.

73. Dagbro O., Torniainen P., Karlsson O., Morén T. (2010) Colour responses from wood, thermally modified in superheated steam and pressurized steam atmospheres. Wood Material Science and Engineering, 5, 211-219.

74. Dashti H., Tarmian A., Faezipour M., Hedjazi S., Shahverdi M. (2012) Effect of pre-steaming on mass transfer properties of fir wood (Abies alba L.); a gymnosperm species with torus margo pit membrane. Bioresources, 7(2), 19071918.

75. Deflorian F., Rossi S., Fedrizzi L., Zanella C. (2007) Comparison of organic coating accelerated tests and natural weathering considering meteorological data. Progress in Organic Coatings, 59, 244-250.

76. Deka M., Humar M., Rep G., Kričej B., Šentjurc M., Petrič M. (2008) Effects of UV light irradiation on colour stability of thermally modified, copper ethanolamine treated and non-modified wood: EPR and DRIFT spectroscopic studies. Wood Science and Technology, 42(1), 5-20.

77. Deka M., Petrič M. (2008) Photo-degradation of water borne acrylic coated modified and non-modified wood during artificial light exposure. Bioresources, 3(2), 346-362.

78. Derbyshire H., Miller E.R. (1981) The photodegradation of wood during solar irradiation. Part I: Effects on the structural integrity of thin wood strips. Holz als Roh- und Werkstoff, 39, 341-350.

79. Derbyshire H., Miller E.R., Turkulin H. (1997) Investigations into the photodegradation of wood using microtensile testing. Part 3: The influence of temperature on photodegradation rates. Holz als Roh- und Werkstoff, 55, 287291.

80. Diffey B.L. (1991) Solar ultraviolet radiation effects on biological systems. Physical Medicine and Biology, 36(3), 299-328.

81. Dubey M.K., Pang S., Walker J. (2011) Changes in chemistry, color, dimensional stability and fungal resistance of Pinus radiata D. Don wood with oil heattreatment. Holzforschung, 66(1), 49-57.

82. Eiropas parlamenta un padomes direktīva 2004/42/EK. (2004) Eiropas Savienūbas Oficiālais Vēstnesis, 15/8, 376-385.

83. Ekstedt J. (2002a) Influence of coating additives on water vapour absorption and desorption in Norway spruce. Holzforschung, 56, 663-668.

84. Ekstedt J. (2002b) Studies on the barrier properties of exterior wood coatings. Doctoral Thesis. KTH, Stockholm. 
85. Ekstedt J., Östberg G. (2001) Liquid water permeability of exterior wood coatings - testing according to a proposed European standard method. Journal of Coatings Technology, 73, 53-59.

86. EN 152 Wood preservatives. Determination of the protective effectiveness of a preservative treatment against blue stain in wood in service. Laboratory method.

87. Engelund E.T., Thygesen L.G., Svensson S., Hill C.A.S. (2013) A critical discussion of the physics of wood-water interactions. Wood Science and Technology, 47, 141-161.

88. Esteves B., Graca J., Pereira H. (2008a) Extractive composition and summative chemical analysis of thermally treated eucalypt wood. Holzforschung, 62, 344351.

89. Esteves B., Marques A.V., Domingos I., Pereira H. (2008b) Heat-induced colour changes of pine (Pinus pinaster) and eucalypt (Eucalyptus globulus) wood. Wood Science and Technology, 42(5), 369-384.

90. Esteves B., Pereira H. (2008) Quality assessment of heat-treated wood by NIR spectroscopy. Holz als Roh-und Werkst, 66, 323-332.

91. Esteves B., Videira R., Pereira H. (2011) Chemistry and ecotoxicity of heattreated pine wood extractives. Wood Science and Technology, 45, 661-676.

92. Evans P.D. (1989) Effect of angle of exposure on the weathering of wood surfaces. Polymer Degradation and Stability, 24, 81-87.

93. Evans P.D. (2013) Weathering of wood and wood composites. In: Handbook of Wood Chemistry and Wood Composites, Second Edition Rowell R.M. (ed.), CRC Press, 151-216.

94. Evans P.D., Michell A.J., Schmalzl K.J. (1992) Studies of the degradation and protection of wood surfaces. Wood Science and Technology, 26, 151-163.

95. Evans P.D., Urban K., Chowdhury M.J.A. (2008) Surface checking of wood is increased by photodegradation caused by ultraviolet and visible light. Wood Science and Technology, 42, 251-265.

96. Evans P.E., Chowdhury J.A. (2010) Phtoprotection of wood using polyester-type UV-absorbers derived from the reaction of 2-hydroxy-4(2,3-epoxypropoxy)benzophenone with dicarboxylic acid anhydrides. Journal of Wood Chemistry and Technology, 30, 186-204.

97. Feist C.F. (1988) Role of pigment concentration in the weathering of semitransparent stains. Forest Product Journal, 38(2), 41-44.

98. Feist W.C. (1990a) Outdoor wood weathering and protection. In: Archeological wood. Properties, Chemistry, and Preservation. Rowell R.M., Barbocer J.R. (ed.), American Chemical Society, Washington, 263-298.

99. Feist W.C. (1990b) Weathering performance of painted wood pretreated with water-repellent preservatives. Forest Product Journal, 40 (7/8), 21-26.

100. Feist W.C., Hon D.N.S. (1984) Chemistry of weathering and protection. In: Chemistry of Solid Wood, Advances in Chemistry, Rowel R.M (ed.), 401-451.

101. Fengel D., Wegener G. (1989) Wood: Chemistry, Ultrastructure, Reactions. Walter De Gruyter, Berlin, 617 p.

102. Ferrari S., Allegretti O., Cuccui I., Moretti N., Marra M., Todaro L. (2013a) A revaluation of Turkey oak wood (Quercus cerris L.) through combined steaming and thermo-vacuum treatments. Bioresources, 8(4), 5051-5066.

103. Ferrari S., Cuccui I., Allegretti O. (2013b) Thermo-vacuum modification of some European softwood and hardwood species treated at different conditions. Bioresources, 8(1), 1100-1109. 
104. Ferrari S., Allegretti O., Cuccui I., Sandak J., Sandak A. (2012) Thermo-vacuum process for wood thermal modification: results for some European softwood and hardwood species treated at different conditions. In: Proceedings of the Eighth European Conference on Wood Modification. Helsinki, Finland, 226-233.

105. De Filpo G., Palermo A.M., Rachiele F. (2013) Preventing fungal growth in wood by titanium dioxide nanoparticles. International Biodeterioration and Biodegradation, 85, 217-222.

106. Fisher K., Beyer M. (2000) Comparison of light-induced and heat-induced yellowing of pulp. Lenxinger Berichte, 79, 25-31.

107. Flæte P.O., Høibø O.A., Fjærtoft F., Nilsen T.N. (2000) Crack formation in unfinished siding of aspen (Populus tremula L.) and Norway spruce (Picea abies (L.) Karst.) during accelerated weathering. Holz als Roh- und Werkstoff, 58, 135139.

108. Fojutowski A., Kropacz A., Noskowiak A. (2011) The susceptibility of poplar and alder wood to mould fungi attack. Annals of Warsaw University of Life Sciences - SGGW, Forest and Wood Technology, 74, 56-62.

109. Forsthuber B., Grüll G. (2010) The effects of HALS in the prevention of photodegradation of acrylic clear topcoats and wooden surfaces. Polymer Degradation and Stability, 95, 746-755.

110. Fredriksson M. (2010) A critical literature review of moisture and temperature condition in wood exposed outdoors above ground. Lund Institute of Technology, Lund University, Report TVBM-3152, Lund, 36.

111. Fromm J., Rockel B., Lautner S., Windeisen E., Wanner G. (2003) Lignin distribution in wood cell walls determined by TEM and backscattered SEM techniques. Journal of Structural Biology, 143, 77-84.

112. Fujita M., Harada H. (2000) Ultrastructure and formation of wood cell wall. In: Wood and Cellulosic Chemistry, Second edition, Hon D.N.S., Shiraishi N. (ed.), Marcel Dekker, New York, 1-81.

113. Funaoka M., Kako T., Abe I. (1990) Condensation of lignin during heating of wood. Wood Science and Technology, 24, 277-288.

114. Galichet L. (ed.) (2012) Solar and ultraviolet radiation. IARC Monographs on the Evaluation of Carcinogenic Risks to Human, 101D, 35-101.

115. George B., Suttie E., Merlin A., Deglise X. (2005) Photodegradation and photostabilisation of wood - the state of the art. Polymer Degradation and Stability, 88, 268-274.

116. Gérardin P., Petrič M., Petrissans M., Lambert J., Ehrhardt J.J. (2007) Evalution of wood surface free energy after heat treatment. Polymer Degradation and Stability, 92, 653-657.

117. Gerlock J.L., Smith C.A., Cooper V.A., Dusbiber T.G., Weber W.H. (1998) On the use of Fourier transform infrared spectroscopy and ultraviolet spectroscopy to assess the weathering performance of isolated clearcoats from different chemical families. Polymer Degradation and Stability, 62, 225-234.

118. Giebeler E. (1983) Dimensionsstabilisierung von $\mathrm{Holz}$ durch eine Feuchte/Wärme/Druck-/Behandlung. Holz als Roh- und Werkstoff, 41(3), 8794.

119. Gillatt J. (1996) The use of biocides and fungicides in wood coatings and preservatives. Pigment and Resin Technology, 25(5), 4-10.

120. Gobakken L.R., Høibø O.A. (2011) Aesthetic service life of coated and uncoated wooden cladding - influencing factors and modelling. The International Research Group on Wood Protection, IRG/WP 11-20470, 1-20. 
121. Gobakken L.R., Høibø O.A., Solheim H. (2010) Mould growth on paints with different surface structures when applied on wooden claddings exposed outdoors. International Biodeteoration and Biodegradation, 64, 339-345.

122. Gobakken P., Lebow K. (2010) Modelling mould growth on coated modified and unmodified wood substrates exposed outdoors. Wood Science and Technology, 44, 315-333.

123. Gobakken P., Vestol.G.I. (2012) Surface mould and blue stain fungi on coated Norway spruce cladding. International Biodeteoration and Biodegradation, 75, 181-186.

124. Gobakken L.R., Westin M. (2008) Surface mould growth on five modified wood substrates coated with three different coating systems when exposed outdoors. International Biodeteoration and Biodegradation, 62, 397-402.

125. González-Peña M.M., Curling S.F., Hale M.D.C. (2009) On the effect of heat on the chemical composition and dimensions of thermally-modified wood. Polymer Degradation and Stability, 94, 2184-2193.

126. González-Peña M.M., Hale M.D.C. (2009a) Colour in thermally modified wood of beech, Norway spruce and Scots pine. Part1: Colour evaluation and colour changes. Holzforschung, 63, 385-393.

127. González-Peña M.M., Hale M.D.C. (2009b) Colour in thermally modified wood of beech, Norway spruce and Scots pine. Part 2: Property predictions from colour changes. Holzforschung, 63, 394-401.

128. Graf N.M., Wagner S., Begander U., Trinkaus P., Boechzelt H., (2005) Gaseous emissions from thermal wood modification as a source for fine chemicals recovery. Joanneum Research GmbH, Graz, Austria.

129. Grekin M. (2006) Wood colour in sapwood and heartwood of Nordic Scots pine and the changes under UV radiation. In: Proceedings of the 5th IUFRO Symposium Wood Structure and Properties '06, 233-238.

130. Grüll G., Tscherne F., Spitaler I., Forsthuber B. (2014) Comparison of wood coating durability in natural weathering and artificial weathering using fluorescent UV-lamps and water. European Journal of Wood Products, 72, 367376.

131. Güner F.S., Yagci Y., Erciyes A.T. (2006) Polymers from triglyceride oils. Progress in Polymer Science, 31, 633-670.

132. Hakkou M., Pértrissans M., Zoulalian A., Gérardin P. (2006) Investigations of the reasons for fungal durability of heat-treated beech wood. Polymer Degradation and Stability, 91(2), 393-397.

133. Hakkou M., Pértrissans M., Zoulalian A., Gérardin P. (2005) Investigations of wood wettability changes during heat treatment on the basis of chemical analysis. Polymer Degradation and Stability, 89, 1-5.

134. Hardcastle H.K, Meeks W.L. (2008) Considerations for characterizing moisture effects in coatings weathering studies. Journal of Coating Technology and Research, 5(2), 181-192.

135. Haveren J., Oostveen E.A., Micciche F., Noordover B.A., Koning C.E., Benthem R.A.T.M., Frissen A.E., Weijnen J.G.J. (2007) Resins and additives for power coatings and alkyd paints, based on renewable resources. Journal of Coating Technology and Research, 4(2), 177-186.

136. Hayoz P., Peter W., Rogez D. (2003) A new innovative stabilization method for the protction of natural wood. Progress in Organic Coatings, 48, 297-309.

137. Heigenmoser A., Liebner F., Windeisen E., Richter K. (2013) Investigation of thermally treated beech (Fagus sylvatica) and spruce (Picea abies) by means of 
multifunctional analytical pyrolysic-GC/MS. Journal of Analytical and Applied Pyrolysis, 100, 117-126.

138. Heitner C. (2010) The Photochemistry of lignin. In: Lignin and Lignans, Advances in Chemistry, Heitner C., Dimmel D.R., Schmidt J.A. (ed.), CRC Press, New York, 555-584.

139. Heräjärvi H. (2009) Effect of drying technology on aspen wood properties. Silva Fennica, 43(3), 433-445.

140. Hernandez V. (2012) Role of non-decay fungi on the weathering of wood. $A$ Thesis submitted in partial Fulfilment of the Requirements for the Degree of Doctor of Philosophy, The University of British Columbia, Vancouver, 578 p.

141. Hill C.A.S. (2009) The potential for the use of modified wood products in the built environment. In: Proceedings of the 11th International Conference on Nonconventional Materials and Technologies, 6-9 September, Bath, UK, 1-8.

142. Hill C.A.S. (2006) Thermal Modification of wood. In: Wood Modification: Chemical, Thermal, and Other Processes. John Willey \& Sons, 99-127.

143. Hill C.A.S., Ramsay J., Keating B., Laine K., Rautkari L., Hughes M., Constant B. (2012) The water vapour sorption properties thermally modified and densified wood. Journal of Material Science, 47, 3191-3197.

144. Hillis W.E., (1984) High temperature and chemical effects on wood stability. Part 1.General considerations. Wood Science and Technology, 18, 281-293.

145. Hillis W.E., Rozsa A.N. (1985) High temperature and chemical effects on wood stability. Part 2. The effect of heat on the softening of radiata pine. Wood Science and Technology, 19, 57-66.

146. Hofland A. (2012) Alkyd resins: From down and out to alive and kicking. Progress in Organic Coatings, 73, 274-282.

147. Hofmann T., Wetzig M., Rétfalvi T., Sieverts T., Bergemann H., Niemz P. (2013) Heat-treatment with the vacuum-press dewatering method: chemical properties of the manufactured wood and the condensation water. European Journal of Wood Products, 71, 121-127.

148. Hon D.N.S (2000) Weathering and Photochemistry of wood. In: Wood and Cellulosic Chemistry, Second edition, Revised, and Expanded, Hon D.N.S., Shiraishi N. (ed.), Marcel Dekker, New York, 513-546.

149. Hon D.N.S., Chang S.T. (1984) Surface degradation of wood by ultraviolet light. Journal of Polymer Science, 22, 2227-2241.

150. Hon D.N.S., Feist W.C. (1992) Hydroperoxidation in photoirradiated wood surfaces. Wood and Fifer Science, 24(4), 448-455.

151. Hon D.N.S., Minemura N. (2000) Color and Discoloration. In: Wood and Cellulosic Chemistry, Second edition, Revised, and Expanded, Hon D.N.S., Shiraishi N. (ed.), 2000, Marcel Dekker, New York, 385-442.

152. Horn B.A., Qiu J., Owen N.L., Feist W.C. (1994) FT-IR studies of weathering effects in western redcedar and southern pine. Applied Spectroscopy, 48, 662668.

153. Huang X., Kocaefe D., Kocaefe Y., Boluk Y., Krause C. (2013) Structural analysis of heat-treated birch (Betula papyrifera) surface during artificial weathering. Applied Surface Science, 264, 117-127.

154. Huang X., Kocaefe D., Kocaefe Y., Boluk Y., Pichette A. (2012a) A spectrocolorimetric and chemical study on color modification of heat-treated wood during artificial weathering. Applied Surface Science, 258, 5360-5369. 
155. Huang X., Kocaefe D., Kocaefe Y., Boluk Y., Pichette A. (2012b) Study of the degradation behaviour of heat-treated jack pine (Pinus banksiana) under artificial sunlight irradiation. Polymer Degradation and Stability, 97, 1197-1214.

156. Hui-Ting, Shang-Tzen C. (2001) Correlation between softwood discolouration induced by accelerated lightfastness testing and by indoor exposure. Polymer Degradation and Stability, 72(2), 361-365.

157. Hukka A., Viitanen H.A. (1999) A mathematical model of mould growth on wooden material. Wood Science and Technology, 33, 475-485.

158. Hyttinen M., Masalin-Weijo M., Kalliokoski P., Pasanen P. (2010) Comparison of VOC emissions between air-dried and heat-treated Norway spruce (Picea abies), Scots pine (Pinus sylvestris) and European aspen (Populus tremula) wood. Atmospheric Environment, 44, 5028-5033.

159. Inari G.N., Petrissans M., Gerardin P. (2007) Chemical reactivity of heat-treated wood. Wood Science and Technology, 41, 157-168.

160. Ishikawa A., Kuroda N., Kato A. (2004) In situ measurement of wood moisture content in high-temperature steam. Journal of Wood Science, 50, 7-14.

161. Jämsä S., Ahola P., Viitaniemi P. (2000) Long-term natural weathering of coated Thermo Wood. Pigment and Resin Technology, 29(20), 68-74.

162. Jeffs R.A., Jones W. (1999) Additives for paint In: Paints and Coatings. Theory and Practice. Second edition. Lambourne R., Strivens T.A. (ed.), Woodhead Publishung Ltd., Cambridge, England, 185-197.

163. Johansson D. (2008) Heat treatment of solid wood. Effects on absorption, strength and colour. Doctoral Thesis, Lulea University of Technology, $142 \mathrm{p}$.

164. Johansson D. (2006) Influences of drying on internal checking of spruce (Picea abies L., ) heat-treated at $212^{\circ} \mathrm{C}$. Holzforschung, 60, 558-560.

165. Johansson D., Morén T. (2006) The potential of colour measurement for strength prediction of thermally treated wood. Holz als Roh-und Werkstoff, 64, 104-110.

166. Johansson P., Jermer J. (2010) Mould growth on wood-based materials - a comparative study. The International Research Group on Wood Protection, IRG/WP 10-20455, 1-9.

167. Kalenda P., Mene P. (2009) Contribution of inorganic pigments to the formation of paint films. Transfer Inovácii, 15, 6-13.

168. Kamdem D. P., Pizzi A., Jermannaud A. (2002) Durability of heat-treated wood. Holz als Roh- und Werkstoff, 60(1), 1-6.

169. Kamdem D.P., Pizzi A., Triboulot M.C. (2000) Heat-treated timber: potentially toxic byproducts presence and extent of wood cell wall degradation. Holz als Roh-und Werkstoff, 58, 253-257.

170. Karlsson O., Morén T. (2010) Colour stabilization of heat modified Norway spruce exposed to out-door conditions. In: Proceedings of the 11th International IUFRO Wood Drying Conference, 265-268.

171. Karlsson O., Torniainen P., Dagbro O., Granlund K., Morén T. (2012) Presence of water-soluble compounds in thermally modified wood: carbohydrates and furfurals. Bioresources, 7(3), 3679-3689.

172. Kataoka Y., Kiguchi M. (2001) Depth profiling of photo-induced degradation in wood by FT-IR microspectroscopy. Journal of Wood Science, 47, 325-327.

173. Kataoka Y., Kiguchi M., Fujiwara T., Evans P.D. (2005) The effects of withinspecies and between-species variation in wood density on the photodegradation depth profiles of sugi (Cryptomeria japonica) and hinoki (Chamaecyparis obtusa). Journal of Wood Science, 51, 531-536. 
174. Kataoka Y., Kiguchi M., Williams R.S., Evans P.D. (2007) Violet light causes photodegradation of wood beyond the zone affected by ultraviolet radiation. Holzforschung, 61(1), 23-27.

175. Kishino M., Nakano T. (2004) Artificial weathering of tropical woods. Part 2: Color change. Holzforschung, 58, 558-565.

176. Kocaefe D., Poncsak S., Doré G., Younsi R. (2008) Effect of heat treatment on the wettability of white ash and soft maple by water. Holz als Roh-und Werkstoff, $66,355-361$.

177. Koch H., Hübner K., Fischer K. (1994) The influence of light on the molecular mass of lignin. Journal of Wood Chemistry and Technology, 14(3), 339-349.

178. Kockott D. (1989) Natural and artificial weathering of polymers. Polymer Degradation and Stability, 25, 181-208.

179. Kolar J., Strlič M., Pihlar B. (2001) New colourimetric method for determination of hydroxyl radicals during ageing of cellulose. Analytica Chimica Acta, 431, 313-319.

180. Korkut D.S., Guller B. (2008) The effects of heat treatment on physical properties and surface roughness of red-bud maple (Acer trautvetteri Medw.) wood. Bioresource Technology, 99, 2846-2851.

181. Krūmiņš J., Dubrovskis D., Priedkalns G., Šmits I., Dağis S. (2013) Koksnes pirmapstrādes uzṇēmumu monitorings un nodrošinājums ar koksnes resursiem. Vietējo resursu (zemes dzīlu, meža, pārtikas un transporta) ilgtspējīga izmantošana - jauni produkti un tehnologijas (NatRes), Valsts pētījumu programma (2010-2013) Rakstu krājums, Rīga, 96-101.

182. Kubojima Y., Okano T., Ohta M. (2000) Bending strength and toughness of heattreated wood. Journal of Wood Science, 46, 8-15.

183. Künniger T., Heeb M., Arnold M. (2014) Antimicrobial efficacy of silver nanoparticles in transparent wood coatings. European Journal of Wood Products, 72, 285-288.

184. Kuo M., Hu N. (1991) Ultrastructural changes of photodegradation of wood surfaces exposed to UV. Holzforschung, 45(5), 347-353.

185. Lambourne R. (1999a) Paint composition and applications - a general introduction. In: Paints and Coatings. Theory and Practice. Second edition. Lambourne R., Strivens T.A. (ed.), Woodhead Publishung Ltd., Cambridge, England, 1-18.

186. Lambourne R. (1999b) Solvents, thinners, and diluents. In: Paints and Coatings. Theory and Practice. Second edition. Lambourne R., Strivens T.A. (ed.), Woodhead Publishung Ltd., Cambridge, England, 166-184.

187. Latthe S.S., Gurav A.B., Maruti C.S., Vhatkar R.S. (2012) Recent progress in preparation of superhydrophobic surfaces: a review. Journal of Surface Engineering Materials and Advanced Technology, 2, 76-94.

188. Lazzari M., Chiantore O. (1999) Drying and oxidative degradation of linseed oil. Polymer Degradation and Stability, 65, 303-313.

189. Lee M.H., Patil U.M., Kochuveedu S.T., Lee C.S., Kim D.H. (2012) The effect of $\mathrm{SiO}_{2}$ shell on the suppression of photocatalytic activity of $\mathrm{TiO}_{2}$ and $\mathrm{ZnO}$ nanoparticles. Bulletin of Korean Chemical Society, 33(1), 3767-3771.

190. Lenth C.A., Kamke F.A. (2001) Equilibrium moisture content of wood in hightemperature pressurized environments. Wood and Fibre Science, 33(1), 104-118.

191. Li J., Henriksson G., Gellerstedt G. (2005) Carbohydrate reactions during hightemperature steam treatment of aspen wood. Applied Biochemistry and Biotechnology, 125, 175-188. 
192. Li X., Cai Z., Mou Q., Wu Y., Liu Y. (2011) Effects of heat treatment on some physical properties of douglas fir (Pseudotsuga Menziesii) wood. Advanced Materials Research, 197-198, 90-95.

193. Lionetto F., Sole R.D., Cannoletta D., Vasapollo G., Maffezzoli A. (2012) Monitoring wood degradation during weathering by cellulose crystallinity. Materials, 5, 1910-1922.

194. Lovrić A., Zdravković V., Furtula M. (2014) Influence of thermal modification on colour of poplar (Populus xeuramericana) rotary cut veneer. Wood Research, 59(2), 661-670.

195.LVG̣MC Piejams: http://www.meteo.lv/meteorologija-datumeklesana/?nid=461 [skatīts 2015.gada 30.septembrī].

196. LVS EN 384:2000 Būvkoki - Mehānisko īpašību raksturlielumu un blīvuma noteikšana.

197. LVS EN 927-1:2013 Krāsas un lakas. Pārklājuma materiāli un sistēmas ārējiem koka darbiem 1. dalı: Klasifikācija un izvēle.

198.LVS EN 927-2:2015 Krāsas un lakas. Pārklājumu materiāli un pārklājumu sistēmas ārējām koka virsmām. 2. daḷa: Veiktspējas specifikācija.

199. LVS EN 927-3:2012 Krāsas un lakas. Pārklājuma materiāli un sistēmas ārējiem koka darbiem 3. dala: Dabīgās novecināšanas tests.

200.LVS EN 927-5:2007 Krāsas un lakas. Pārklājumu materiāli un pārklājumu sistēmas koksnei ārdarbos. 5. dalıa: Ūdens caurlaidības novērtēšana.

201. LVS EN 927-6:2007 Krāsas un lakas. Pārklājumu materiāli un pārklājumu sistēmas koksnei ārdarbos. 6. daḷa: Koksnes materiālu pārklājumu mākslīgā novecināšana, izmantojot UV luminiscences spuldzes un ūdeni.

202. LVS EN ISO 16948:2015 Cietais biokurināmais. Kopējā oglekḷa, ūdeṇraža un slāpekḷa satura noteikšana.

203. Mahltig B., Böttcher H., Rauch K., Dieckmann U., Nitsche R., Fritz T. (2005) Optimized UV protecting coatings by combination of organic and inorganic UV absorbers. Thin Solid Films, 485, 108-114.

204. Majano-Majano A., Hughes M., Fernandez-Cabo J.L. (2012) The fracture toughness and properties of thermally modified beech and ash at different moisture contents. Wood Science and Technology, 46, 5-21.

205. Mathiazhagan A., Rani J. (2011) Nanotechnology - a new prospective in organic coating - review. International Journal of Chemical Engineering and Applications, 2(4), 225-237.

206. Matsuo M., Umemura K., Kawai S. (2012) Kinetic analysis of color changes in cellulose during heat treatment. Journal of Wood Science, 58(2), 113-119.

207. Matsuo M., Yokoyama M., Umemura K., Sugiyama J., Kawai S., Gril J., Kubodera S., Mitsutani T., Ozaki H., Sakamoto M., Imamura M. (2011) Aging of wood: Analysis of color changes during natural aging and heat treatment. Holzforschung, 65, 361-368.

208. Matsuoka S., Kawamoto H., Saka S. (2011) Reducing end-group of cellulose as a reactive site for thermal discoloration. Polymer Degradation and Stability, 96, $1242-1247$.

209. Mayes D., Oksanen O. (2003) ThermoWood ${ }^{\circledR}$ Handbook, Finish Thermowood Association, Helsinki, 53.

210. Mehrotra R., Singh P., Kandpal H. (2010) Near infrared spectroscopic investigation of the thermal degradation of wood. Thermochimica Acta, 507-508, $60-65$. 
211. De Meijer M., Militz H. (2000a) Moisture transport in coated wood. Part 1: Analysis of sorption rates and moisture content profiles in spruce during liquid water uptake. Holz als Roh-und Werkstoff, 58, 354-362.

212. De Meijer M., Militz H. (2000b) Moisture transport in coated wood. Part 2: Influence of coating type, film thickness, wood species, temperature and moisture gradient on kinetics of sorption and dimensional change. Holz als Roh-und Werkstoff, 58, 467-475.

213. De Meijer M., Thurich K., Militz H. (1998) Comparative study on penetration characteristics of modern wood coatings. Wood Science and Technology, 32, 347-365.

214. De Meijer M., Thurich K., Militz H. (2001) Quantitative measurements of capillary coating penetration in relation to wood and coating properties. Holz als Roh- und Werkstoff, 59, 35-45.

215. Meincken M., Evans P.D. (2009) Nanoscale characterization of wood photodegradation using atomic force microscopy. European Journal for Wood Products, 67(2), 229-231.

216. Menezzi C.H.S., Tomaselli I., Okino E.Y.A., Teixeira D.E., Santana M.A.E. (2009) Thermal modification of consolidated oriented strandboards: effects on dimensional stability, mechanical properties, chemical composition and surface color. European Journal of Wood and Wood Products, 67, 383-396.

217. Metsä-Kortelainen S., Antikainen T., Viitanen H. (2006) The water absorption of sapwood and heartwood of Scots pine and Norway spruce heat-treated at $170^{\circ} \mathrm{C}, 190^{\circ} \mathrm{C}, 210^{\circ} \mathrm{C}$ and $230^{\circ} \mathrm{C}$. Holz als Roh-und Werkstoff, 64, 192-197.

218. Metsä-Kortelainen S., Paajanen L., Viitanen H. (2011) Durability of thermally modified Norway spruce and Scots pine in above-ground conditions. Wood Material Science and Engineering, 6(4), 163-169.

219. Metsä-Kortelainen S., Viitanen H. (2012) Wettability of sapwood and heartwood of thermally modified Norway spruce and Scots pine. European Journal of Wood and Wood Products, 70, 135-139.

220. Meža nozare Latvijas 20 neatkarības gados, (2012), Beķeris P. (red.), BALTI Group, 48 lpp.

221. Micciché F.M., Oostveen E., van Haveren J., van der Linde R. (2005) The combination of reducing agents/iron as environmentally friendlier alternatives for Co-based driers in the drying of alkyd paints. Progress in Organic Coatings, 53, 99-105.

222. Miklečić J., Jirouš-Rajković V., Antonović A., Španić N. (2011) Discolouration of thermally modified wood during simulated indoor sunlight exposure. Bioresources, 6(1), 434-446.

223. Militz H. (2015) Wood modification in Europe in the Year 2015: a success story? In: Proceedings of the Eighth European Conference on Wood Modification, 2015, Helsinki, Finland, 17 p.

224. Militz H., Altgen M. (2014) Processes and properties of thermally modified wood manufactured in Europe. Deterioration and Protection of Sustainable Biomaterials. 1158, 269-285.

225. Miranda T.J. (1993) Surface Coatings Volume 1 Raw Materials and their Usage, Third Edition, Chapman and Hall, London, 622 p.

226. Mitani A., Barboutis I. (2013) Heat treatment effect on colour changes of beech (Fagus sylvatica) wood. Pro Ligno, 9(4), 658-663. 
227. Mitsui K., Tsuchikawa S. (2005) Low atmospheric temperature dependence on photodegradation of wood. Journal of Photochemistry and Photobiology B: Biology, 81, 84-88.

228. Molinski W., Fabisiak E., Srodecki L. (2010) Selected mechanical properties of thermally modified Amercan ash wood. Annals of Warsaw University of Life Sciences-SGGW, Forestry and Wood Technology, 72, 32-36.

229. Molnar-Hamwas L., Csonka-Rakosa R., Börcsök E., Molnar J., Nemeth K. (2006) Colour and spectral changes of the wood surface due to ultra-violet light exposition and impregnation with chromium. Wood Structure and Properties '06, 313-320.

230. Müller U., Rätzsch M., Schwanninger M., Steiner M., Zöbl H. (2003) Yellowing and IR-changes of spruce wood as a result of UV-irradiation. Journal of Photochemistry and Photobiology B: Biology, 69(2), 97-105.

231. Nabuur T., Baijards R.A., German A.L. (1996) Alkyd-acrylic hybrid systems for use as binders in waterborne paints. Progress in Organic Coatings, 27, 163-172.

232. Nazerian M., Ghalehno M.D., Kashkooli A.B. (2011) Effect of wood species, amount of juvenile wood and heat treatment on mechanical and physical properties of laminated veneer lumber. Journal of Applied Science, 11(6), 981987.

233. Niemz P., Hofmann T., Rétfalvi T. (2010) Investigation of chemical changes in the structure of thermally modified wood. Maderas Ciencia y Technologia, 12(2), $69-78$.

234. Nikolic M., Lawther J.M., Sanadi A.R. (2015) Use of nanofillers in wood coatings: a scientific review. Journal of Coating Technology and Research, $12(3), 445-461$.

235. Nuopponen M., Vuorinen T., Jämsä S., Viitaniemi P. (2003) The effects of a heat treatment on the behaviour of the extractives in softwood studied by FTIR spectroscopic methods. Wood Science and Technology, 37, 109-115.

236. Nuopponen M., Vuorinen T., Jämsä S., Viitaniemi P. (2004a) Thermal Modifications in Softwood studied by FT-IR and UV resonance Raman spectroscopies. Journal of Wood Chemistry and Technology, 24(1), 13-26.

237. Nuopponen M., Wikberg H., Vuorinen T., Maunu S.L., Jämsä S., Viitaniemi P. (2004b) Heat-treated softwood exposed to weathering. Journal of Applied Polymer Science, 91(4), 2128-2134.

238. Nussbaum R.M., Sutcliffe E.J., Hellgren A.C. (1998) Microautoradiographic studies of the penetration of alkyd, alkyd emulsion and linseed oil coatings into wood. Journal of Coatings Technology, 70(878), 49-57.

239. Nzokou P., Kamdem D.P. (2006) Influence of wood extractives on the photodiscoloration of wood surfaces exposed to artificial weathering. Color Research and Application, 31(5), 425-434.

240. Ohkoshi M. (2002) FTIR-PAS study of light-induced changes in the surface of acetylated or polyethylene glycol-impregnated wood. Journal of Wood Sciences, 48, 394-401.

241. Oltean L., Teischinger A., Hansmann C. (2008) Wood surface discolouration due to simulated indoor sunlight exposure. Holz als Roh-und Werkstoff, 66, 51-56.

242. Owen J.A., Owen N.L., Feist W.C. (1993) Scanning electron microscope and infrared studies of weathering in Southern pine. Journal of Molecular Structure, 300, 105-114.

243. Özgenc O., Forsthuber B., Teischinger A., Hansmann C. (2010) Comparison of colour change in wood clear-coating systems including inorganic and organic 
UV absorbers for exterior use. The International Research Group on Wood Protection, IRG/WP 10-40499, 1-10.

244. Özgenc O., Hiziroglu S., Yildiz U. (2012) Weathering properties of wood species treated with different coating applications. Bioresources, 7(4), 4875-4888.

245. Özgenc O., Okan O.T., Yildiz U.C., Deniz I. (2013) Wood surface protection against artificial weathering with vegetable seed oils. Bioresources, 8(4), 62426262.

246. Ozola E., (2015) Krāsas. Uztvere un iedarbība. J.L.V., Rīga, 244 lpp.

247. Pagnozzi E. (2012) Apparatus comprising a vacuum autoclave for the high temperature modification of wood. Patent EP $2535156 \mathrm{Al}$.

248. Pandey K.K. (2005a) A note on the influence of extractives on the photodiscoloration and photo-degradation of wood. Polymer Degradation and Stability, 87, 375-379.

249. Pandey K.K. (2005b) Study of the effect of photo-irradiation on the surface chemistry of wood. Polymer Degradation and Stability, 90, 9-20.

250. Pandey K.K., Khali D.P. (1998) Accelerated weathering of wood surfaces modified by chromium trioxide. Holzforschung, 52(5), 467-471.

251.Pandey K.K., Vuorinen T. (2008a) Comparative study of photodegradation of wood by a UV laser and a xenon light source. Polymer Degradation and Stability 93(12), 2138-2146.

252. Pandey K.K., Vuorinen T. (2008b) UV resonance Raman spectroscopic study of photodegradation of hardwood and softwood by UV laser. Holzforschung, 62, 183-188.

253. Papp G., Preklet E., Košiková B., Barta E., Tolvaj L., Bohus J., Szatmári S., Berkesi O. (2004) Effect of UV laser radiation with different wavelength on the spectrum of lignin extracted from hard wood materials. Journal of Photochemistry and Photobiology A: Chemistry, 163, 187-192.

254. Pauler M. (2002) Paper Optics. AB Lorentzen and Wettre, Kista, Sweden, 93 p.

255. Perré P. (2011) On the importance of the temperature level on coupled heat and mass transfer in wood and ligno-cellulosic biomass: fundamental aspects, formulation and modelling. European Drying Conference - EuroDrying'2011, Palma Balearic Island, Spain, 55-62.

256. Perré P., Rémond R., Turner I. (2013) A comprehensive dual-scale wood torrefaction model: Application to the analysis of thermal run-away in industrial heat treatment processes. International Journal of Heat and Mass Transfer, 64, 838-849.

257. Persze L., Tolvaj L. (2012) Photodegardation of wood at elevated temperature: Colour change. Journal of Photochemistry and Photobiology B: Biology, 108, 44-47.

258. Peters J., Fischer K., Fischer S. (2008) Characterization of emissions from thermally modified wood and their reduction by chemical treatment. Bioresources, 3(2), 491-502.

259. Pfriem A. (2011) Alteration of water absorption coefficient of spruce (Picea abies (L.) Karst.) due to thermal modification. Drvna Industrija, 62(4), 311-313.

260. Pfriem A., Buchelt B., Zauer M., Wagenführ A. (2010) Comparative analysis of thermally modified and native spruce loaded perpendicular to the grain. European Journal of Wood Products, 68, 267-270.

261. Pfriem A., Zauer M., Wagenfuhr A. (2009) Alteration of the pore structure of spruce (Picea abies (L.) Karst.) and maple (Acer pseudoplatanus L.) due to 
thermal treatment as determined by helium pycnometry and mercury intrusion porosimetry. Holzforschung, 63, 94-98.

262. Ploeger R., Scalarone D., Chiantore O. (2009) Thermal analytical study of the oxidative stability of artists' alkyd paints. Polymer Degradation and Stability, 94, 2036-204.

263. Podgorski L., Arnold M., Hora G. (2003) A reliable artificial weathering test for wood coatings. Coating World, 2, 39-48.

264. Podgorski L., Merlin A., Saiter J.M. (1994) Natural and artificial ageing o fan alkyd based wood finish. Journal of Thermal Analysis, 41, 1319-1324.

265. QUV and Weathering Technical Bulletins. Pieejams: http://www.qlab.com/resources/technical-bulletins.aspx [skatîts 2015.gada 20.novembrī].

266. Rapp A.O., Brischke C., Welzbacher C.R. (2006) Interrelationship between the severity of heat treatments and sieve fractions after impact ball milling: a mechanical test for quality control of thermally modified wood. Holzforschung, 60(1), 64-70.

267. Rapp O.A. (ed.) (2001) Review on heat treatments of wood. In: Proceedings of Special Seminar held in Antibes, France on 9 February 2001, COST ACTION E22 Environmental optimisation of wood protection, 68.

268. Rautkari L., Hill C.A.S. (2014) Effect of initial moisture content on the antiswelling efficiency of thermally modified Scots pine sapwood treated in a highpressure reactor under saturated steam. Holzforschung, 68(3), 323-326.

269. Rautkari L., Hill C.A.S., Curling S., Jalaludin Z., Ormondroyd G. (2013) What is the role of the accessibility of wood hydroxyl groups in controlling moisture content? Journal of Material Science, 48, 6352-6356.

270. Reinprecht L. (2010) Fungicides for wood protection - world viewpoint and evaluation/testing in Slovakia. In: Fungicides, Carisse O. (ed.), InTech, Croatia, 95-122.

271. Repellin V., Guyonnet R. (2005) Evaluation of heat treated wood swelling by differential scanning calorimetry in relation with chemical composition. Holzforschung, 59(1), 28-34.

272. Richter K., Feist W.C., Knaebe M.T. (1995) The effect of surface roughness on the performance of finishes. Part 1. Roughness characterization and stain performance. Forest Products Journal, 45 (7/8), 91-97.

273. Rijckaert V., Stevens M., Van Acker J. (2001a) Effect of some formulation parameters on the penetration and adhesion of water-borne primers into wood. Holz als Roh- und Werkstoff. 59, 344-350.

274. Rijckaert V., Stevens M., Van Acker J., Meijer M., Militz H. (2001b) Quantitative assessment of the penetration of water-borne ans solvent-borne wood coatings in Scots pine sapwood. Holz als Roh-und Werkstoff. 59, 278287.

275. Ringman R., Pilgard A., Brischke C., Richter K. (2014) Mode of action of brown rot decay resistance in modified wood: a review. Holzforschung, 68(2), 239-246.

276. Ringman R., Pilgard A., Kölle M., Brischke C., Richter K. (2015) Effects of thermal modification on Postia placenta wood degradation dynamics: measurements of mass loss, structural integrity and gene expression. Wood Science and Technology, Published online: 07 December 2015. DOI 10.1007/s00226-015-0791-Z

277. Rosu D., Teace C.A., Bodirlau R., Rosu L. (2010) FTIR and color of the modified wood as a result of artificial light irradiation. Journal of Photochemistry and Photobiology B: Biology, 99, 144-149. 
278. Rousset P., Perré P., Girard P. (2004) Modification of mass transfer properties in poplar wood (P. Robusta) by a thermal treatment at high temperature. Holz als Roh-und Werkstoff, 62, 113-119.

279. Rowell R.N., Andersone I., Andersons B. (2013) Heat treatment. In: Handbook of Wood Chemistry and Wood Composites, Second Edition Rowell R.M. (ed.), CRC Press, 511-536.

280. Rowell R.M., Ibach R.E., McSweeny J., Nilsson T. (2009) Understanding decay resistance, dimensional stability and strength changes in heat-treated and acetylated wood. Wood Materials Science and Engineering, 1-2, 14-22.

281. Saha S., Kocaefe D., Boluk Y., Pichette A. (2011a) Enhancing exterior durability of jack pine by photo-stabilization of acrylic polyurethane coating using bark extract. Part 1: Effect of UV on color change and ATR-FT-IR analysis. Progress in Organic Coatings, 70, 376-382.

282. Saha S., Kocaefe D., Krause C., Boluk Y., Pichette A. (2013) Enhancing exterior durability of jack pine by photo-stabilization of acrylic polyurethane coating using bark extract. Part 2: Wetting characteristics and fluorescence microscopy analysis. Progress in Organic Coatings, 76, 504-512.

283. Saha S., Kocaefe D., Krause C., Larouche T. (2011c) Effect of titania and zinc oxide particles on acrylic polyurethane coating performance. Progress in Organic Coatings, 70, 170-177.

284. Saha S., Kocaefe D., Sarkar D.K., Boluk Y., Pichette A. (2011b) Effect of $\mathrm{TiO}_{2}-$ containing nano-coatings on the color protection of heat-treated jack pine. Journal of Coating Technology and Research, 8(2), 183-190.

285. Sailer M.F., van Nieuwenhuijzen E.J., Knol W. (2012) Forming of a functional biofilm on wood surface. Ecological Engineering, 36, 163-167.

286. Salmén L., Bergström E. (2009) Cellulose structural arrangement in relation to spectral changes in tensile loading FTIR. Cellulose, 16, 975-982.

287. Salmén L., Burgert I. (2009) Cell wall features with regard to mechanical performance. A review. Holzforschung, 63, 121-129.

288. Salmén L., Possler H., Stevanic J.S., Stanzi-Tschegg S.E. (2008) Analysis of thermally treated wood samples using dynamic FT-IR-spectroscopy. Holzforschung, 62, 676-678.

289. Sandak A., Sandak J., Cuccui I., Allegretti O., Zanuttini R., Negro F., Cremonini C., Rosso L., Castro G. (2015) Thermal modification of poplar veneers in vacuum conditions. In: Proceedings of the Eighth European Conference on Wood Modification. Helsinki, Finland, 255-261.

290. Sandberg D. (1999) Weathering of radial and tangential wood surfaces of pine and spruce. Holzforschung, 53(4), 355-364.

291. Sandberg D., Haller P., Navi P. (2013) Thermo-hydro and thermo-hydromechanical wood processing: An opportunity for future environmentally friendly wood products. Wood Material Science and Engineering, 8(1), 64-88.

292. Sandberg D., Söderström O. (2006) Crack formation due to weathering of radial and tangential sections of pine and spruce. Wood Material Science and Engineering, 1(1), 12-20.

293. Sayar M., Tarmian A. (2012) Effect of Thermal Treatment on Water Vapour Diffusion Coefficient of Poplar Wood (Populus nigra L.) In: Proceedings of the Sixth European Conference on Wood Modification, Ljubljana, Slovenia, 297300.

294. Schaller C., Rogez D. (2007) New approaches in wood coating stabilization. Journal of Coatings Technology and Research, 4(4), 401-409. 
295. Schaller C., Rogez D., Braig A. (2008) Hindered amine stabilizers in pigmented coatings. Journal of Coatings Technology and Research, 5(1), 25-31.

296. Schaller C., Rogez D., Braig A. (2009) Hydroxyphenyl-s-triazines: advanced multipurpose UV-absorbers for coatings. Journal of Coatings Technology and Research, 6(1), 81-88.

297. Schauwecker C.F., McDonald A., Preston A.F., Morrell J.J. (2014) Use of iron oxides to influence the weathering characteristics of wood surfaces: a systematic survey of particle size, crystal shape and concentration. European Journal of Wood Products, 72, 669-680.

298. Schauwecker C.F., McDonald A.G., Morrell J.J. (2013) Performance of wood treated with prospective organic surface protectants upon outdoor exposure: FTIR spectroscopic analysis of weathered surfaces. Holzforschung, 67(2), 227235.

299. Schnabel T., Zimmer B., Petutschnigg A.J. (2009) On the modelling colour changes of wood surfaces. European Journal of Wood and Wood Products, 67, 141-149.

300. Schnabel T., Zimmer B., Petutschnigg A.J., Schönberger S. (2007) An approach to classify thermally modified hardwoods by color. Forest Products Journal, 57(9), 105-110.

301. Severo E.T.D., Calonego F.W., Sansígolo C.A. (2012) Physical and chemical changes in juvenile and mature woods of Pinus elliotti var. Elliotti by thermal modification. European Journal of Wood and Wood Products, 70, 741-747.

302. Sharratt V., Hill C.A.S., Kint D.P.R. (2009) A study of early colour change due to simulated accelerated sunlight exposure in Scots pine (Pinus sylvestris). Polymer Degradation and Stability, 94, 1589-1594.

303. Siversten M., S., Flæte P.O. (2012) Water absorption in coated Norway spruce (Picea abies) cladding. European Journal of Wood Products, 70, 307-317.

304. Sivrikaya H., Hafizoglu H., Yasav A., Aydemir D. (2011) Natural weathering of oak (Quercus petrae) and Chestnut (Castanea sativa) coated with various finishes. Colour Research and Application, 36 (1), 72-78.

305. Sjöström E. (1993) Wood Chemistry - Fundamentals and applications. Academic Press, Inc., London, UK, 293 p.

306. Skaar C. Wood-Water Relations. Springer Verlag, Berlin, 1988, 283 p.

307. Skarvelis M., Mousilopoulos K. (2014) Colour alteration of beech wood during and after drying. Journal of International Scientific Publications: Materials, Methods and Technologies, 8, 292-799.

308. Skwomand E., Christensen P. (2003) Patent A method and an apparatus for heat treatment of wooden objects WO 2003106123 A2.

309. Srinivas K., Pandey K.K. (2012) Photodegradation of thermally modified wood. Journal of Photochemistry and Photobiology B: Biology, 117, 140-145.

310. Stamm A.J. (1942) U.S. Patent No 2,296,316, Antishrink Treatment for Wood.

311. Stamm A.J., Burr H.K., Kline A.A. (1946) Staybwood. Heat-stabilized wood. Industrial and Engineering Chemistry, 38(6), 630-634.

312. Stenbæk J. (2015) Bio-sustainable control of the blue stain fungi Aureobasidium pullulans on exterior wood coatings. PhD Thesis, University of Copenhagen, The Faculty of Science, $244 \mathrm{p}$.

313. Step E.N., Turro N.J., Gande M.E., Klemchuk P.P. (1994) Mechanism of Polymer Stabilization by Hindered-Amine Light Stabilizers (HALS). Model Investigations of the Interaction of Peroxy Radicals with HALS Amines and Amino Ethers. Macromolecules, 27(9), 2529-2539. 
314. Stingl R., Gierlinger N., Zukal M.L., Meints T., Teischinger A. (2012) Change in colour composition of thermally modified oak veneer after exposure to laboratory light sources. In: Proceedings of the Sixth European Conference on Wood Modification, Ljublana, Slovenia, 243-246.

315. Stirling R., Morris P.I. (2013) Improved coating performance on wood treated with carbon-based preservatives and an ultraviolet/visible light protective precoat. Forest Product Journal, 63(3-4), 95-100.

316. Stirling R., Uzunovic A., Morris P.I. (2011) Control of black stain fungi with biocides in semitransparent wood coatings. Forest Product Journal, 61(5), 359364.

317. Sudiyani Y., Tsujiyama S., Imamura Y., Takahashi M., Minato K., Kajita H. (1999) Chemical characteristics of surfaces of hardwood and softwood deteriorated by weathering. Journal of Wood Science, 45, 348-353.

318. Sundqvist B. (2002) Color response of Scots pine (Pinus sylvestris), Norway spruce (Picea abies) and birch (Betula pubescens) subjected to heat treatment in capillary phase. Holz als Roh-und Werkstoff, 60, 106-114.

319. Sundqvist B., Karlsson O., Westermark U. (2006) Determination of formic-acid and acetic acid concentrations formed during hydrothermal treatment of birch wood and its relation to colour, strength and hardness. Wood Science and Technology, 40, 549-561.

320. Sundqvist B., Morén T. (2002) The influence of wood polymers and extractives on wood colour induced by hydrothermal treatment. Holz als Roh- und Werkstoff, 60(5), 375-376.

321. Temiz A., Terziev N., Eikenes M., Hafren J. (2007) Effect of accelerated weathering on surface chemistry of modified wood. Applied Surface Science, 253, 5355-5362.

322. Temiz A., Yildiz U.C., Aydin I., Eikenes M., Alfredsen G., Çolakoglu G. (2005) Surface roughness and color characteristics of wood treated with preservatives after accelerated weathering test. Applied Surface Science, 250, 35-42.

323. Tjeerdsma B.F., Boonstra M., Pizzi A., Tekely P., Militz H. (1998) Characterisation of thermally modified wood: Molecular reasons for wood performance improvement. Holz als Roh-und Werkstoff, 56, 149-153.

324. Tjeerdsma B.F., Militz H. (2005) Chemical changes in hydrothermal treated wood: FTIR analysis of combined hydrothermal and dry heat-treated wood. Holz als Roh- und Werkstoff, 63, 102-111.

325. Tolvaj L., Faix O. (1995) Artificial ageing of wood monitored by DRIFT spectroscopy and CIEL*a*b* color measurements. Holzforschung, 49, 397-404.

326. Tolvaj L., Mitsui K. (2010) Correlation between hue angle and lightness of light irradiated wood. Polymer Degradation and Stability, 95, 638-642.

327. Tolvaj L., Mitsui K. (2005) Light source dependence of the photodegradation of wood. Journal of Wood Science, 51, 468-473.

328. Tolvaj L., Nemeth R., Pasztory Z., Bejo L., Takats P. (2014) Colour stability of thermally modified wood during short-term photodegradation. Bioresources, 9(4), 6644-6651.

329. Tolvaj L., Persze L., Albert L. (2011) Thermal degradation of wood during photodegradation. Journal of Photochemistry and Photobiology B: Biology, 105, 90-93.

330. Tolvaj L., Varga D. (2012) Photodegradtion of timber of three hardwood species caused by different light sources. Acta Silvatica et Lignaria Hungarica, 8, 145155 . 
331. Tracton A.A. (ed.) (2007) Coatings Technology Fundamentals, Testing, and Processing Techniques. CRC Press, $370 \mathrm{p}$.

332. Tuong V.M., Li J. (2010) Effect of heat treatment on the change in color and dimensional stability of acacia hybrid wood. Bioresources, 5(2), 1257-1267.

333. Turkulin H., Derbyshire H., Miller E.R. (2004) Investigations into the photodegradation of wood using microtensile testing. Part 5: The influence of moisture on photodegradation rates. Holz als Roh-und Werkstoff, 62, 307-312.

334. Turner I., Rousset P., Rémond R., Perré P. (2010) An experimental and theoretical investigation of the thermal treatment of wood (Fagus sylvatica L.) in the range $200-260{ }^{\circ} \mathrm{C}$. International Journal of Heat and Mass Transfer, 53, $715-725$.

335. Twede D. (2006) The cask age: The technology and history of wooden barrels. Packing Technology and Science, 18(5), 253-264.

336. Van Meel P.A., Erich S.J.F., Huinink H.P., Kopinga K., de Jong J., Adan O.C.G. (2011) Moisture transport in coated wood. Progress in Organic Coatings, 72, 686-694.

337. Viitanen H. (2002) Mould growth on painted wood. In: Proceedings of Special Seminar COST E18: Bio-Deterioration of Wood-Coating and Substrate, April 4-5, Lisbon, 9.

338. Viitanen H., Vinha J., Salminen K., Ojanen T., Peuhkuri R., Paajanen L., Lähdesmäki K. (2010) Moisture and bio-deterioration risk of building materials and structures, Journal of Building Physics, 33, (3), 201-224.

339. Wang X., Ren H. (2008) Comparative study of the photo-discoloration of moso bamboo (Phyllostachys pubescens Mazel) and two wood species. Applied Surface Science, 254, 7029-7034.

340. Weiland J.J., Guyonnet R. (2003) Study of chemical modification and fungi degradation of thermally modified wood using DRIFT spectroscopy. Holz als Roh-und Werkstoff, 61, 216-220.

341. Welzbacher C.R., Brischke C., Rapp A.O. (2007) Influence of treatment temperature and duration on selected biological, mechanical, physical and optical properties of thermally modified timber. Wood Material Science and Engineering, 2, 66-76.

342. Welzbacher C.R., Meyer L., Brischke C. (2010) Prediction of flooring-relevant properties based on colour values of thermally modified timber (TMT). In: Proceedings of the 5th European Conference on Wood Modification, Riga, Latvia, 143-150.

343. Welzbacher C.R., Rassam G., Talaei A., Brischke C. (2011) Microstructure, strength and structural integrity of heat-treated beech and spruce wood. Wood Material Science and Engineering, 6, 219-227.

344. Widman R., Fernandez-Cabo J.L., Steiger R. (2012) Mechanical properties of thermally modified beech timber for structural purposes. European Journal of Wood and Wood Products, 70(6), 775-784.

345. Wikberg H., Maunu S.L. (2004) Characterisation of thermally modified hardand softwoods by 13C CPMAS NMR. Carbohydrate Polymers, 58, 461-466.

346. Willems W. P. M. (2008) Method and apparatus for preserving wood, and wood product Patent No. WO 2008079000 Al.

347. Willems W. (2015) Glass polymer formation in thermally modified wood: effects on long-term moisture and durability performance in service. In: Proceedings of the Eighth European Conference on Wood Modification, Helsinki, Finland, 234240 . 
348. Willems W. (2014) The water vapour sorption mechanism and its hysteresis in wood: the water/void mixture postulate. Wood Science and Technology, 48(3), 499-518.

349. Willems W., Altgen M., Militz H. (2015) Comparison of EMC and durability of heat treated wood from high versus low water vapour pressure reactor systems. International Wood Products Journal, 6(1), 21-26.

350. Willems W., Gérardin P., Militz H. (2013) The average carbon oxidation state of thermally modified wood as a marker for its decay resistance against basiomycetes. Polymer Degradation and Stability, 98, 2140-2145.

351. Williams R.S. (2009) Testing painted wood: Past practices at the Forest Products Laboratory and recommendations for future research. In: Proceedings of The Third International Coating Wood and Wood Composites: Durability and Sustainability - today and Beyond, 1-28.

352. Williams R.S., Jourdain C., Daisey G., Springate R.W. (2000) Wood properties affecting finish service life. Journal of Coating Technology, 72, 35-42.

353. Williams R.S., Knaebe M.T., Sotos P.G., Feist W.C. (2001a) Erosion rates of wood during natural weathering. Part I. Effects of grain angle and surface texture. Wood and Fibre Science, 33(1), 31-42.

354. Williams R.S., Knaebe M.T., Feist W.C. (2001b) Erosion rates of wood during natural weathering. Part II. Earlywood and latewood erosion rates. Wood and Fibre Science, 33(1), 43-49.

355. Williams R.S., Knaebe M.T., Evans J.W., Feist W.C. (2001c) Erosion rates of wood during natural weathering. Part III. Effects of exposure angle on erosion rate. Wood and Fibre Science, 33(1), 50-57.

356. Windeisen E., Strobel C., Wegener G. (2007) Chemical changes during the production of thermo-treated beech wood. Wood Science and Technology, 41, 523-536.

357. Windeisen E., Wegener G. (2008) Behaviour of lignin during thermal treatments of wood. Industrial Crops and Products, 27, 157-162.

358. Yao C., Yongming F., Jianmin G., Houkum L. (2012) Coloring characteristics of in situ lignin during heat treatment. Wood Science and Technology, 46, 33-40.

359. Yildiz S., Yildiz U.C., Tomak E.D. (2011) The effects of natural weathering on the properties of heat-treated alder wood. Bioresources, 6(3), 2504-2521.

360. Zahri S., Belloncle C., Charrier F., Pardon P., Quideau S., Charrier B. (2007) UV light impact on ellagitannins and wood surface colour of European oak (Quercus petraea and Quercus robur). Applied Surface Science, 253, 4985-4989.

361. Zaķis G̣. (2008) Koksnes ķīmijas pamati. SIA Tipogrāfija Pērse, Rīga, 200 lpp.

362. Zauer M., Pfriem A., Wagenführ A. (2013) Toward improved understanding of the cell-wall density and porosity of wood determined by gas pycnometry. Wood Science and Technology, 47(6), 1197-1211.

363. Živković V., Arnold M., Radmanović K., Richter K., Turkulin H. (2014) Spectral sensitivity in the photodegradation of fir wood (Abies alba Mill.) surfaces: colour changes in natural weathering. Wood Science and Technology, 48, 239-252. 